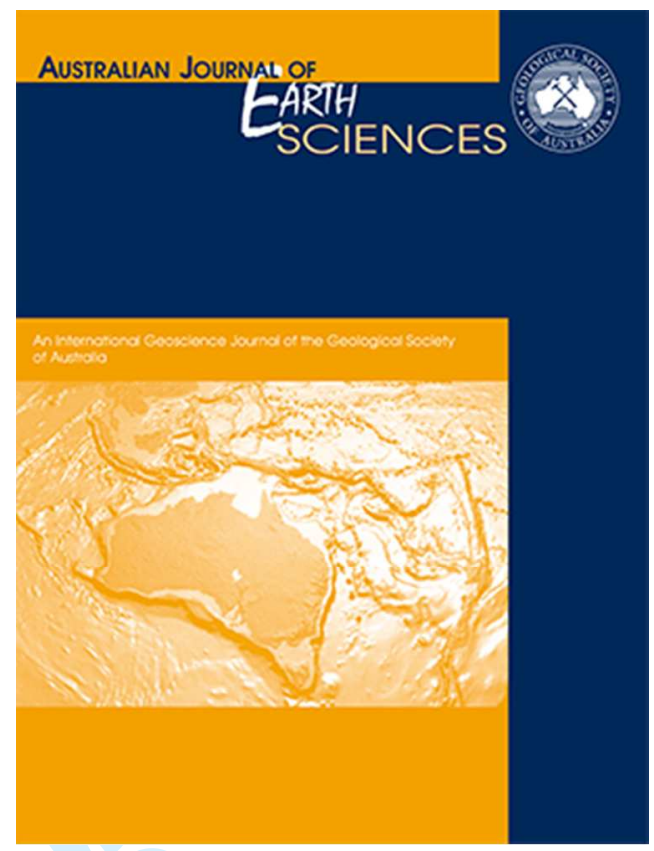

\title{
East Antarctic sources of extensive Early-Middle Ordovician turbidites in the Lachlan Orogen, Tasmanides, SE Australia
}

\begin{tabular}{|r|l|}
\hline Journal: & Australian Journal of Earth Sciences \\
\hline Manuscript ID & TAJE-RES-2015-0058.R2 \\
\hline Manuscript Type: & Research Paper \\
\hline Complete List of Authors: & $\begin{array}{l}\text { Glen, Richard; Macquarie University, Department of Earth \& Planetary } \\
\text { Sciences } \\
\text { Fitzsimons, I; Curtin University of Technology, School of Applied Geology } \\
\text { Griffin, William; Macquarie University, , Department of Earth \& Planetary } \\
\text { Sciences } \\
\text { Saeed, Ayesha; Macquarie University, Department of Earth \& Planetary } \\
\text { Sciences }\end{array}$ \\
\hline Keywords: & $\begin{array}{l}\text { tasmanides, lachlan orogen, zircon, provenance, antarctica, ordovician, } \\
\text { ross orogen }\end{array}$ \\
\hline
\end{tabular}

\section{SCHOLARONE $^{\text {MN }}$ \\ Manuscripts}




\title{
East Antarctic sources of extensive Lower-Middle Ordovician
} turbidites in the Lachlan Orogen, of the southern Tasmanides, eastern Australia

\author{
R. A. Glena, I. C. W. Fitzsimons ${ }^{b}$, W. L. Griffina,c and A. Saeeda \\ a National Key Centre for Geochemical Evolution and Metallogeny of Continents, Department of \\ Earth \& Planetary Sciences, Macquarie University, Sydney, NSW 2109, Australia \\ b Department of Applied Geology and the Institute for Geoscience Research, Western Australian \\ School of Mines, Curtin University, GPO Box U1987, Perth, WA 6845, Australia \\ c ARC Centre of Excellence for Core to Crust Fluid Systems (CCFS), Department of Earth \& \\ Planetary Sciences, Macquarie University, Sydney, NSW 2109, Australia
}

Received 3 May 2015; accepted 1 November, 2016

\begin{abstract}
Lower to upper Middle Ordovician quartz-rich turbidites form the bedrock of the Lachlan Orogen in the southern Tasmanides of eastern Australia, and occupy a present-day deformed volume of $\sim 2-2.3$ million $\mathrm{km}^{3}$. We have used $\mathrm{U}-\mathrm{Pb}$ and Hf-isotope analyses of detrital zircons in biostratigraphically constrained turbiditic sandstones from three separate terranes of the Lachlan Orogen to investigate possible source regions and to compare similarities and differences in zircon populations. Comparison with shallow-water Lower Ordovician sandstones deposited on the subsiding margin of the Gondwana craton suggest different source regions, with Grenvillian zircons in the latter derived from the Musgrave Province in central Australia, and Panafrican sources in the latter possibly locally derived. All Ordovician turbiditic sandstone samples in the Lachlan Orogen are dominated by ca 490-620 Ma (late Panafrican) and ca 950$1120 \mathrm{Ma}$ (late Grenvillian) zircons that are sourced mainly from East Antarctica. Subtle differences between samples point to different sources. In particular, the age consistency of late Panafrican zircon data from the most inboard of our terranes (Castlemaine Group, Bendigo Terrane) suggests they may have emanated directly from late Grenvillian East Antarctic belts, such as in Dronning Maud Land and subglacial extensions that were reworked in the late Panafrican. Changes in zircon data in the more outboard Hermidale and Albury-Bega terranes are more consistent with derivation from the youngest of four sedimentary sequences of the Ross Orogen of Antarctica (Cambrian-Ordovician upper Byrd Group, Liv Group and correlatives referred to here as sequence 4) and/or from the same mixture of sources that supplied that sequence. These sources include uncommon ca 650 Ma rift volcanics, late Panafrican Ross arc volcanics, now largely eroded, and some < 545 Ma Granite Harbour Intrusives, representing the roots of the Ross Orogen continental margin arc. Unlike farther north, Granite Harbour Intrusives between the Queen Maud and Pensacola mountains of the southern Ross Orogen contain late Grenvillian zircon xenocrysts (derived from underlying relatively juvenile basement), as well as late Panafrican magmatic zircons and are thus able to supply sequence 4 and the Lachlan Ordovician turbidites with both these two populations. Other zircons and detrital muscovites in the Lachlan Ordovician turbidites were derived from relatively juvenile
\end{abstract}


inland Antarctic sources external to the orogen (e.g. Dronning Maud Land, Sør Rondane and a possible extension of the Pinjarra Orogen) either directly, or recycled through older sedimentary sequences 2 (Beardmore and Skelton groups) and 3 (e.g. Hannah Ridge Formation) in the Ross Orogen. Shallow-water, forearc basin sequence 4 sediments (or their sources) fed turbidity currents into outboard, deeper water parts of the forearc basin and led to deposition of the Ordovician turbidites $\sim 2500-3400 \mathrm{~km}$ to the north in backarc-basin settings of the Lachlan Orogen.

Key words: detrital zircon dating, U-Pb, Hf isotopes, turbidites, sediment sources, Antartica, Lachlan Orogen, Tasmanides

\section{Introduction}

The southern Tasmanides (Figure 1a) contain several Ordovician tectonostratigraphic elements summarised in the Supplementary Papers (Table A1). In the Delamerian Orogen in the west, shallow-water Lower Ordovician sandstones were deposited after the ca 500 Ma Delamerian Orogeny on the subsiding Gnalta Shelf, east and north of Broken Hill, in far western NSW (Greenfield, Musgrave, Bruce, Gilmore, \& Mills, 2011; Webby, 1978; Figure 1a). The Lachlan Orogen to the east is dominated by quartz-rich, Lower to Middle Ordovician turbiditic rocks (Figure 1a). Glen, Percival and Quinn (2009) placed these units in three main sedimentary terranes (Figure 1a, b), based firstly on the presence or absence of conformably overlying, starved Upper Ordovician black shales, and secondly by the presence of graptoliferous laminated shales in the inboard Bendigo Terrane versus conodont-bearing cherts in the outboard Albury-Bega and Hermidale terranes (Table 1).

Lower to Middle Ordovician turbidites crop out, and are inferred to underlie younger rocks, over an area of $\sim 235000-270000 \mathrm{~km}^{2}$ (Figure 1a). The volume of this lithotectonic association is hard to estimate because of repeated thrusting, except in central Victoria where the Castlemaine Group of the Bendigo Terrane has a stratigraphic thickness of $\sim 3.3 \mathrm{~km}$ (VandenBerg and Stewart, 1992), and a present-day structural thickness, based on deep seismic reflection profiling, of $10 \mathrm{~km}$ (Cayley et al., 2011). Based on this structural thickness and a present-day surface area (outcropping and inferred) of 200000 to $230000 \mathrm{~km}^{2}$, the total volume of this association is $\sim 2$ to 2.3 million $\mathrm{km}^{3}$ (see Table 1 for $\mathrm{g}$ ). If this thickness were on average $50 \%$ too high, the volume of Lower-Middle Ordovician turbidites is still an impressive 1.1-1.2 million $\mathrm{km}^{3}$.

The vast volume of these turbidites means that resolving their nature is essential to understanding the evolution of the Lachlan Orogen. The scale of this problem only became apparent in the mid-1980s, when the identification of Lower to Middle Ordovician conodonts in cherts in the Adaminaby Group in NSW and Victoria and in the Girilambone Group of northwestern NSW showed that they were coeval with the Castlemaine Group in central Victoria, the graptolite biostratigraphy of which had been known for over a century (e.g. Glen and VandenBerg, 1987; Glen, Stewart, \& VandenBerg, 1990; Hall, 1899; Harris, 1916; Percival, Quinn, \& Glen, 2011; Stewart, 1988; Stewart and Glen, 1986; VandenBerg \& Stewart, 1992). The insertion of the basement Selwyn Block underlying central Victoria, approximately the region between the Heathcote Fault Zone and Governor Fault Zone (in Figure 1a), led to subdivision of the huge the Ordovician basin depocentre into a western part (Castlemaine Group, thinning and becoming less sandy eastwards) and an eastern part, occupied in Victoria mainly by the 
Adaminaby Group (e.g. Cayley, 2011; Cayley, Taylor, VandenBerg, \& Moore, 2002; Glen, Belousova, \& Griffin, 2016).

In the first part of this paper, we use $\mathrm{U}-\mathrm{Pb}$ and $\mathrm{Hf}$-isotope data from detrital zircon grains to discuss possible source regions and sedimentary distributary patterns in Lower Ordovician sandstones on the Gnalta Shelf, in the Koonenberry Belt, north and east of Broken Hill (NSW) in the Delamerian Orogen. We foreshadow differences with the zircon patterns in Lower Ordovician to upper Middle Ordovician turbiditic sandstones in the Lachlan Orogen that form the subject of the second part of this paper, in which we document the U-Pb and $\varepsilon_{\mathrm{Hf}}$ data of their detrital zircons. The third part of the paper explores differences and similarities in zircon ages and geochemistry between different Lachlan Ordovician turbidite packages, that have implications for Ordovician tectonics. The fourth part examines possible source regions, both in Australia and in Antarctica, for these turbiditic sandstones, with our data suggesting an origin in East Antarctica.

\section{Approach}

Detrital zircons were collected from specific time slices in Lower and Middle Ordovician sediments from different terranes in the southern Tasmanides. Three samples were collected from Lower Ordovician sedimentary rocks of the Gnalta Shelf: one from basal conglomerate and two from $\sim 90 \%$ quartz-rich sandstone beds higher up (Figures $1 \mathrm{~b}$ and $2 \mathrm{a}$ ). All the other samples came from sandstone beds in the deeper-water turbidite terranes of the Lachlan Orogen: three from the Castlemaine Group (Bendigo Terrane), four from the Girilambone Group (Hermidale Terrane), two from the Wagga Group (Albury-Bega Terrane west) and four from the Adaminaby Group (Albury-Bega Terrane east). Location details are given in Supplementary papers (Table A1).

Sandstones in Ordovician turbidites may be cleaved and show low-grade metamorphism. Thicker beds (e.g. $>50 \mathrm{~cm}$ ) are either massive or graded upwards; thinner beds $(5-15 \mathrm{~cm})$ commonly display classical Bouma features (e.g. Glen, 1994; VandenBerg et al., 2000). Each of the sampled turbiditic sandstones consists of framework grains lying in a fine-grained 'hash' matrix (Figure 2b, c). QEMSCAN data measuring modal mineralogy show that framework grains (Figure $2 \mathrm{~b}, \mathrm{c}$ ) are dominated by quartz, which range from $\sim 52$ to $\sim 80$ vol\% in the turbiditic sandstones (Figure 2a; e.g. Colquhoun, Fergusson, \& Tye, 1999; Glen \& Wyborn 1997; Meffre, Scott, Glen, \& Squire, 2007, see below). In decreasing order of abundance, other framework grains are alkali feldspar, kaolinite after feldspar, plagioclase, biotite/phlogopite and muscovite (Figure 2a). Sandstones from the Willigam Sandstone Member below the Mummel Chert Member (Adaminaby Group; Figure 1b) differ in being less texturally mature and less well sorted (Thomas and Pogson, 2012) a feature also found in early Ordovician sandstone in central Victoria by Fergusson and Tye (1999). Although the framework grains in this sample are still dominantly quartz there are up to $10 \mathrm{vol} \%$ lithic grains, comprising mainly fine-grained sandstone, siltstone, and chert (Figure 2c). Feldspar (alkali and plagioclase) is up to $10 \mathrm{vol} \%$, and there are 1-2 vol\% plutonic rock fragments, some with quartz-feldspar intergrowths, quartz-muscovite intergrowths and apparent quartz phenocrysts in a fine-grained feldspathic groundmass (Thomas \& Pogson, 2012).

\section{Methods and data presentation}

In part two, we describe $\mathrm{U}-\mathrm{Pb}$ and $\varepsilon_{\mathrm{Hf}}$ plots of concordant zircon grains in each sample, as well as a comparison of intra-terrane sample data and of model ages. Some extra, weighted mean plots 
are included in the Supplementary Papers (Supplementary Papers, Appendix 1). The U-Pb plots include Concordia diagrams, probability density plots that show age peaks for all the grains and subpopulations, and histogram age plots for whole populations and for internal groups. Weighted mean ages are generally close to age peaks, but we find that they give a better idea of the spread of ages and numbers of grains. Age peaks and mean ages do not carry any genetic implications for zircon sources. We measured $\mathrm{Hf}$ for all but four samples. The $\varepsilon_{\mathrm{Hf}}$ plots, involve fewer grains than the U-Pb plots, and show source magma types from which the zircons crystallised, based on trace element geochemical analysis of zircon grains following the methods of Belousova, Walters, Griffin, O'Reilly, \& Fisher (2002). Five magma types are present: granitoids $<65 \mathrm{wt} \% \mathrm{SiO}_{2}$ (which we shorten to low-silica); granitoids with $70-75 \mathrm{wt} \% \mathrm{SiO}_{2}$ (which we shorten to high-silica); mafic, alkaline, and rarely syenitic.

In this paper, we refer to age groupings from younger to older, based on our reading of $\mathrm{U}-\mathrm{Pb}$ probablity plots from left to right and because we describe younger age populations before older ones. As discussed in Supplementary Papers (Appendix 4), we will use the term 'late Panafrican' to apply to zircons 490-620 Ma in age, and 'late Grenvillian' for those 950-1120 Ma in age. These numbers are averages based on all our analysed grains.

In any study of detrital zircon grains, it seems obvious that the more grains analysed, the better the statistical definition that can be placed on any population. While 100 grains might be an appropriate number, questions of cost and available instrument time resulted in us attempting to analyse $\sim 60$ grains per sample, in order to maintain a comparable database, a number reduced by those grains with $>10 \%$ discordance. Andersen (2005) suggested that analysing 50 detrital zircon grains per sample would only miss those age grains that made up $<10 \%$ of the population. In contrast, Pullen et al. (2014) queried 100-grain datasets and investigated datasets of 1000 analyses. Rather than increasing the number of $\mathrm{U}-\mathrm{Pb}$ analyses, we considered that a better way of adding value to our $\mathrm{U}-\mathrm{Pb}$ datasets was to carry out $\mathrm{Lu}-\mathrm{Hf}$ analyses of the same grains. Combining the two datasets with biostratigraphic control enables us to look for any changes within each stratigraphic group with time (intra-terrane changes), and between terranes (inter-terrane changes). We are aware of the probability of natural variation between samples (although two samples, TrittonNE and Mwb1 from the same general locality and age sequence are very similar), the limited natures of our datasets, and the possibility of overinterpretation of any 'random' variation between samples. Work likes this provides a framework for others to test.

The Supplementary Papers include full data sets and background data. Table A1 summarises the Ordovician terrane framework of the Lachlan and Delamerian orogens and sample locations. Table A2 summarises the interpretations of the $\mathrm{U}-\mathrm{Pb}, \varepsilon$ and $\mathrm{T}_{\mathrm{DM}(\mathrm{C})}$ data of each sample. Table $\mathrm{A} 3$ summarises potential Australian sources. Table A4 does the same for the East Antarctic shield, and Tables A5 and A6 for igneous and sedimentary rocks respectively in the Ross Orogen of Antarctica. Appendix 1 presents additional weighted mean plots for U-Pb zircon populations. Appendix 2 details the analytical procedures and methods; Appendix 3 shows the probability and histogram plots of for the model age data used in Table 2, where they are shown as peak ages with 1 sigma spread. Appendix 4 details our use of terms late Panafrican and late Grenvillian populations. Appendix 5 supplements the text summary of published detrital zircon data from sedimentary sequences in the Ross Orogen. U-Pb and $\varepsilon_{\mathrm{Hf}}$ data are tabulated as Excel spreadsheets in Appendices 6 and 7. 


\section{General description of zircons}

Zircons are generally yellow-pink-red in colour, with some white. Grains are 50 to 200 microns in size, varying from elongate to equant, and from mostly rounded and subrounded to anhedral to rarely euhedral (Figure 3). Oscillatory zoning occurs in the majority of grains, albeit very faintly in some, with the remainder featureless. We infer igneous origins. We have found no correlation between the age of a zircon and its shape in any of our populations that are described below: 490-620 Ma zircons may be just as angular or as rounded as the 950-1120 Ma or even early Paleoproterozoic zircons (Figure 3). Rims and cores were noted in some grains, with some patterns apparently complex. However, the thinness of rims or their discordant natures, coupled with the common discordances of cores, precluded meaningful comparison of core-rim data and this aspect of the zircon story awaits further analysis and interpretation.

\section{Part One: descriptions of detrital zircons in Gnalta Shelf rocks}

After the $c a 500$ Ma Delamerian Orogeny, the outboard margins of the Delamerian Orogen in the Koonenberry Belt of far western NSW became the sites of upper Cambrian to Lower Ordovician progressive shallow to deep-water deposition on the Gnalta Shelf (Figure 1) (e.g. Greenfield, Gilmore, \& Mills, 2010). In the Scropes Range east of Broken Hill, the basal stratigraphic unit is the polymictic Bilpa Conglomerate (Pahl and Sikorska, 2004; Percival et al., 2011). It passes upward into the monomictic quartz-pebble Nuchea Conglomerate and then into the conformably overlying fluviatile to shallow Scropes Range Formation (Greenfield et al., 2010). The Yandaminta Quartzite is correlated with the upper part of the Scropes Range Formation (Percival et al., 2011).

\section{Bilpa Conglomerate}

Background geology is summarised in the Supplementary Papers (Table A1). Analysis of 50 zircons from one granite clast $\sim 30 \mathrm{~cm}$ diameter (061B2-1) shows a unimodal zircon age population at $501 \pm 8 \mathrm{Ma}$, inferred to be the age of granite crystallisation (Figure 4). Note in this regard that Greenfield et al. (2010, figure 147b) shows detrital ages from Scropes Range Formation sample 06E1 rather than from the matrix of the Bilpa Conglomerate.

06E1 Scropes Range Formation

Sixty-three zircons were analysed, with 3 rejected because of discordance $>10 \%$. Plots of the remaining 60 zircons (Figure 5a, b) lie along concordia with one exception. The age and probability plots show ages between $c a 400$ and 3000 Ma (Figure 5c, d) with a dominant late Panafrican age group between $c a$ 490-600 Ma (age peaks of 561>591, 515 Ma) and a secondary Grenvillian population between $c a 1050$ and 1260 Ma (age peaks of $1180 \gg 1088 \mathrm{Ma}$ ). A lone zircon grain dated at $438 \mathrm{Ma}$ is inferred to represent metamorphic zircon growth (Supplementary Papers, Appendix 1).

Figure 5e shows that the late Panafrican population contains a 5 -grain group dated between 480-520 Ma. Removing the youngest grain produces a mean age of 4/5 grains at $514 \pm 5 \mathrm{Ma} \mathrm{k}$ (Figure A5i in Appendix 1) that corresponds to the 515 Ma peak. There is a spread of 12 grains from $c a$ 540-570 Ma (containing the 561 Ma peak and a mean from the oldest 9/12 grains of $562 \pm 3 \mathrm{Ma}$ (Figure A5j in Appendix 1). Another age subgroup between ca 580-600 Ma contains the peak at $591 \mathrm{Ma}$ and has a mean age from 5/5 grains of $590 \pm 5$ Ma (Figure A5k in Appendix 1). 
The secondary Grenvillian population (Figure 5f) contains a spread of 10 grains dated from $c a$ 1040 to $1150 \mathrm{Ma}$ and a spread of 14 grains with ages from $c a 1160$ to $1200 \mathrm{Ma}$, containing the peak at $1180 \mathrm{Ma}$ and a low probability mean age using all 14 grains of $1183 \pm 8$ Ma (Appendix 1, Figure A5l).

$\varepsilon$ values for the late Panafrican population are dominantly -6.5 to +1 (cluster 4 ) with some from 18 to -10 (including cluster 5; Figure $5 \mathrm{~g}, \mathrm{~h}$ ). These grains are derived from a mixture of lowsilica granitoids with some alkaline and mafic rocks. $\varepsilon$ values for the Grenvillian zircons are mainly -2 to 0 and +2 to +6.5 in clusters 1 and 2 (Figure $5 \mathrm{~g}$, h). These grains are derived mainly from low-silica granitoids. Three zircons dated between $c a$ 640-720 Ma with positive $\varepsilon$ are derived from mafic + syenitic rocks (cluster 3 in Figure $5 \mathrm{~h}$ ).

606 Yandaminta Quartzite

Sixty zircons were analysed, with 4 rejected because of discordance greater than $10 \%$. Of the remaining 56, with the exception of two zircons dated at $c a 2400 \mathrm{Ma}$, all other zircons lie on concordia (Figure 6a, b). The age and probability plots show 56 zircons between $c a 400$ and $3300 \mathrm{Ma}$ (Figure 5c, d), with a dominant late Panafrican age group between ca 480-600 Ma (age peaks at 515>497》587 Ma) and a secondary Grenvillian population between $c a 1000$ and 1220 Ma (age peak of 1177>>1071 Ma). Grains between 1550-1800 Ma have an age peak at $1662 \mathrm{Ma}$, while grains around 2600 Ma have an age peak 2624 Ma (Figure 6d).

Figure 6e shows that the late Panafrican population contains 12 grains dated around $500 \mathrm{Ma}$ containing the peak at $515 \mathrm{Ma}$, but which cannot be represented by a single mean age with any meaning. However, the youngest 5 grains, with a peak of $497 \mathrm{Ma}$, have a mean age of $495 \pm 5 \mathrm{Ma}$. 6/7 older grains have a mean age of $514 \pm 5 \mathrm{Ma}$, and corresponding peak of $515 \mathrm{Ma}$ (Figure A6i, j in Appendix 1). An older group of 4 grains dated at ca 580 Ma contains the peak at $585 \mathrm{Ma}$ and a corresponding mean age from all 4 grains of $585 \pm 7$ Ma (Figure A6k in Appendix 1).

The secondary Grenvillian population (Figure 6f) consists of: (i) a spread of 12 grains dated between $\mathrm{ca}$ 1020-1145 Ma, producing the peak at $1071 \mathrm{Ma}$; (ii) 7 grains dated between ca 1160-1190 Ma, producing the peak at $1177 \mathrm{Ma}$ and a low probability mean age of $1176 \pm 7 \mathrm{Ma}$ (Figure A6l in Appendix 1); and (iii) a spread of 3 grains from ca 1220 to $1190 \mathrm{Ma}$.

$\varepsilon_{\mathrm{Hf}}$ values of the late Panafrican zircons range mainly from -10 to $\sim-3$, define cluster 4 , and are mainly granitoid-derived (Figure 6g, h). In the Grenvillian population most zircons are derived from granitoids. 6 grains have negative $\varepsilon_{\mathrm{Hf}}(-5.2$ to 0 ; cluster 1$): 12$ grains have positive $\varepsilon_{\mathrm{Hf}}$ values $(+2.9$ to +9.2 ; cluster 2 ; Figure $6 \mathrm{~g}, \mathrm{~h})$

Three grains dated between 701-650 Ma (peak at $700 \mathrm{Ma}$ ) have $\varepsilon_{\mathrm{Hf}}$ values from +2.3 to +6.5 and are derived from mafic and granitic melts (Figure $6 \mathrm{~g}, \mathrm{~h}$ ).

\section{Comparisons between Gnalta Shelf samples}

Both sandstone samples have a dominant ca 480-600 Ma age population and a secondary ca 1050-1250 Ma age population. In the younger population, the main 561 Ma peak in the Scropes Range Formation sample is not matched in the Yandaminta Quartzite sample, although its two flanking age peaks (515 and $591 \mathrm{Ma}$ ) are matched (515 and $585 \mathrm{Ma}$; Figure 7a). The $\varepsilon_{\mathrm{Hf}}$ plots for this population overlap, although Scropes Range Formation has more juvenile grains: compare clusters 4 and 5 in the Scropes Range Formation with cluster 4 in the Yandaminta Quartzite (Figure 7b, c). 
Neither sample contains significant numbers of grains between 950-1050 Ma-a major point of difference with Ordovician turbidite samples discussed below.

A key feature of the secondary 1050-1250 Ma population is the presence of dominant age peaks at 1180 Ma in Scropes Range Formation and 1177 Ma in the Yandaminta Quartzite (Figure 7a), and their near-identical but poor to moderate means of $1183 \pm 8 \mathrm{Ma}$ and $1176 \pm 7 \mathrm{Ma}$, respectively (Figures 5 and 6), despite their separation by $200 \mathrm{~km}$ along strike and up to $15 \mathrm{Ma}$ in age. The $\varepsilon_{\mathrm{Hf}}$ values of this population are also very similar, with each sample containing two tight clusters, one with positive $\varepsilon_{\mathrm{Hf}}$ (cluster 2 in both) and a lesser one with negative $\varepsilon_{\mathrm{Hf}}$ (cluster 1 in both), each derived from mainly low-silica granitoids (Figure $7 \mathrm{~b}, \mathrm{c}$ ).

Both samples also contain ca $700 \mathrm{Ma}$ zircons derived from mafic melts (cluster 3, 640-720 Ma, $\varepsilon_{\mathrm{Hf}}=+4.5$ to +8 in the Scropes Range Formation and $650-701 \mathrm{Ma}, \varepsilon_{\mathrm{Hf}}=+2.3$ to +6.5 in the Yandaminta Quartzite; Figure 7b, c). The small percentages of these are shown in the histograms of Figure 7 (d, e), which show the dominance in both samples of zircons derived from low-silica $\left(<65 \mathrm{wt} \% \mathrm{SiO}_{2}\right)$ melts.

Crustal model ages $\left(\mathrm{T}_{\mathrm{DM}} \mathrm{C}\right)$ of different zircon clusters are shown as peak ages with a 1 sigma spread in Table 2 . They are also shown approximately in the $\varepsilon_{\mathrm{Hf}}$ figures by projecting crustal evolution lines, represented by the envelopes to different clusters, to the Depleted Mantle evolution line (Figure 7b, c). Calculated model ages of clusters 2 and 4 in Figure 7 (b, c) are similar in both samples and suggest extraction from ca 1.3-1.8 Ga continental crust. In the Scropes Range Formation sample clusters 1 and 5 have similar crustal model ages, suggesting the parental magmas of the zircons in both clusters were extracted from 1.8-2.0 Ga continental crust. The zircons derived from mafic magmas in cluster 3 of the Scropes Range Formation and Yandaminta Quartzite project back to the Depleted Mantle ( $\mathrm{T}_{\mathrm{DM}}$ ) at 1.0 to $1.4 \mathrm{Ga}$, which suggests extraction of the host magmas from the mantle at this time.

\section{Possible source regions}

The most likely source region of the 1177 and 1180 Ma zircons is the Musgrave Province of central Australia, exhumed in the Petermann Orogeny. Smithies et al. (2014) summarised the province's evolution as: (i) 1550-1650 Ma juvenile convergent-margin magmatism; (ii) 13121326 Ma granites in the southwestern part with continental arc affinities; (iii) the 1150-1220 Ma Musgrave Orogeny; (iv) emplacement of huge amounts of mantle-derived magmas into the crust (the Giles Event) between ca 1010/1040 and 1090 Ma; (v) the Petermann Orogeny dated between 530 and 570-600 Ma, which exhumed rocks of the Musgrave Province (e.g. Maidment, Williams, \& Hand, 2007). Model ages for the Musgrave Province are 1.9-2.0 Ga (Smithies et al., 2011) and 1.8-2.8/3.0 Ga (Gum and Belousova, 2006).

The Musgrave Orogeny included emplacement of granites of the Pitjantjatjara Supersuite between ca 1120-1220 Ma, with magmatic zircons between ca 1150 and $1190 \mathrm{Ma}$ and the main peak at ca 1180 Ma (Maboko, McDougall, Zeitler, \& Williams, 1992; Smithies et al., 2011). The most widespread of these plutons have $\varepsilon_{\mathrm{Hf}}$ between -6 and -2 (Smithies et al., 2014), and are thus potential sources for detrital zircons with $\varepsilon_{\mathrm{Hf}}$ values from -6 to 0 . The more common 1140 and 1170 Ma zircon populations in the Gnalta Shelf samples, with $\varepsilon_{\mathrm{Hf}}$ values of -2 to +10 , are derived from low-silica granitic magmas, are best sourced from the less common intrusive suites in the Musgrave Province such as the Walpa $\left(\varepsilon_{\mathrm{Hf}}-2.5\right.$ to +7$)$ and Mirturtu $\left(\varepsilon_{\mathrm{Hf}}-1.3\right.$ to +4 ; Smithies et al., 2011). However, the ca 1120-1220 Ma Walpa Suite (Smithies et al., 2011) is too old, so the best match is the 'late Musgravian' (1155-1190 Ma) Mirturtu Suite, especially, since 
its $\mathrm{SiO}_{2}$ content from 61.59 to $78.02 \mathrm{wt} \%$, with significant clustering between 61 and $65 \mathrm{wt} \%$ (Smithies et al., 2011), is consistent with the magma source plots (Figure 7) that indicate a dominance of low-silica granitoid sources $\left(\mathrm{SiO}_{2}<65 \mathrm{wt} \%\right)$ for the Gnalta Shelf samples.

As a note of caution, Belousova, Reid, Griffin, \& O'Reilly (2009) recorded a significant population of zircon ages at $1169 \pm 48$ Ma with positive $\varepsilon_{\mathrm{Hf}}$ values from modern stream catchments in the Gawler Craton. They attributed these zircons to a source within the Gawler Craton, based on the absence of the 1300-1400 Ma zircons found in the Musgrave Province. Both of our shelf samples contain rare 1500-1600 Ma, zircons with primitive $\varepsilon_{\mathrm{Hf}}$, consistent with an island-arc event recognised from the Musgrave Province, from the Gawler Craton and from northern Australia by Wade, Barovich, Hand, Scrimgeour \& Close (2006).

A small population of 1550-1700 Ma zircons in the Yandaminta Sandstone, but less prevalent in the Scropes Range Formation, could have come either from the Musgrave Province or the Willyama Supergroup, centred on Broken Hill. The latter unit underwent rifting at ca $1700 \mathrm{Ma}$, followed by peak contractional deformation and metamorphism at ca 1600 Ma with subsequent magmatism, deformation/lower grade metamorphism at 1550-1590 Ma (Page, Stevens, \& Gibson, 2005).

We suggest that the 1071 and 1088 Ma peaks associated with positive values of $\varepsilon_{\mathrm{Hf}}$ and derived largely from low-silica granitoids and one mafic source, in the Scropes Range Formation and Yandaminta Quartzite, respectively, record the emplacement of mafic to felsic lavas of the ca 1040-1090 Ma Giles Event in the Musgrave Province.

Given the likelihood that the Grenvillian zircons were derived from the Musgrave Province, what about the Panafrican zircons? Did they also come from central Australia or from a different source such as the Koonenberry Belt in the Delamerian Orogen, or even Antarctica? There does not appear to be much evidence for a source in the Musgrave Province. Although this province was exhumed in the Petermann Orogeny, this event did not involve significant granitic magmatism, despite producing abundant migmatites (Scrimgeour and Close, 1999). Of course, it is possible that 500-600 Ma granites may be concealed beneath younger sediments or have been eroded. However, available data suggest that the two main populations were derived from different geographic regions.

An obvious source of the Panafrican population is the Koonenberry Belt with the 590 Ma zircons derived from primitive mafic rocks probably sourced from the alkaline Arrowsmith Volcanics. These form part of the second rifting event along the Gondwana margin (Crawford, Stevens, \& Fanning, 1997; Direen \& Crawford, 2003; Glen, 2013; Glen et al., 2016) and are dated at $586 \pm 6$ Ma (Crawford et al., 1997) and $586 \pm 7$ Ma (Black, 2007). The 501 Ma granite boulder in the Bilpa Conglomerate member (Figure 4) is also locally derived. This age peak overlaps with the 506 Ma peak in the Yandaminta Quartzite. In the Scropes Range Formation 499 and $508 \mathrm{Ma}$ zircons are largely swamped by the 515 Ma peak. Despite this, a $500 \mathrm{Ma}$ local granite is not yet known. The Williams Creek Granite is dated at $515 \pm 3$ Ma (Greenfield et al., 2011), while diorites in the poorly-dated middle to upper Cambrian Evelyn Creek Volcanics may be in the range 498-504 Ma (Greenfield et al., 2010).

It is possible Neoproterozoic parts of the Delamerian Orogen also contributed zircons, since both shelf samples contain a discrete cluster of ca 640-720 Ma juvenile zircons, the parental melts of which were derived from 1.0 to 1.4 Ga mafic crust. The age of 640-720 Ma corresponds to Sturtian glaciation, which was followed by possibly amagmatic rifting in the Adelaide Rift 
Complex, and with the deposition of the Tapley Hill Formation both east and west of the Torrens Hinge Zone and into the Centralian Basin (Preiss, 2000). Barovich and Foden (2000) and Zhao, McCulloch, \& Bennett (1992) noted the contribution of an unidentified basaltic source with relatively primitive Nd to sedimentary rocks up to Tapley Hill Formation time (ca $640 \mathrm{Ma}$ ). Farther afield, this 640-720 Ma detrital zircon cluster correlates with ca 692 Ma plutonism in the Paterson Orogen (Durocher, Kyser, Marlatt, \& Hanly, 2003), and in the Leeuwin Complex of the Pinjarra Orogen (see below), although it also coincides with a rifting event in the Ross Orogen of East Antarctica (see below). Our preference is the unknown source identified by Barovich and Foden (2000), opening-up the possibility of some Adelaidean sources in the hinterland as well as local Koonenberry sources picked up by paleocurrents emanating from central Australia.

The third possibility is that the Panafrican zircons originated in Antarctica, our preferred source of the zircons in the Lachlan Ordovician turbidites discussed in the fourth part of this paper. In such a case, the Gnalta Shelf would have received Grenvillian age grains from central Australia and Panafrican age grains from Antarctica. This is similar to the conclusion reached by Maidment et al. (2007) for sedimentary rocks in the Amadeus Basin. They suggested that lower parts of the basin were supplied by zircons from the Musgrave Province, but that Panafrican zircons (and associated Grenvillian zircons) in the upper parts were derived from mixed sources, with an increasingly dominant source from East Antarctica or the Mozambique Belt of the East African Antarctic Orogen, via the Pacific Gondwana margin.

Such a double source for the Gnalta Shelf sandstones, while feasible, seems complex. It is not supported by the mismatch in Panafrican age zircon populations, with 510-515 Ma zircons in shelf samples coinciding with a gap (except for a sole 514 Ma grain in TrittonNE) in the turbidite samples (Figure 25); or by the dominance of Panafrican age shelf zircons derived from low-silica granitoid melts compared to high-silica granitoid melts for Panafrican age shelf zircons in the turbidites (see below)

Our preferred sources are thus the Musgrave Province for the Grenvillian age population and parts of the Delamerian Orogen for the Panafrican age population.

\section{The Musgrave Province distributary system}

Based on the last paragraph, here we examine the evidence from the 1177 and 1180 Ma peaks for a distributary system emanating from the Musgrave Province. Other sedimentary rocks derived from this province occur in the Amadeus Basin of central Australia (as suggested by Maidment et al., 2007), with one notable example being the Cambrian Ayers Rock Arkose at Uluru, which contains a single 1180 Ma zircon population (Camacho, Hensen, \& Armstrong, 2002). Whether the Gnalta Shelf and the Amadeus Basin were physically connected or independent, yet both yoked to the same source is moot.

The eastern extent of distributary system(s) sourced from the Musgrave Province is intriguing. A widespread depocentre in the Koonenberry Belt is implied by: (i) the post-Delamerian Orogeny Jeffreys Flat Formation (Warratta Group), which has a major zircon-age peak at $1076 \mathrm{Ma}$, coinciding with the age of the Giles Complex, but missing the 1170 Ma peak and instead having peaks at $c a 1570,1440$ and $1329 \mathrm{Ma}$, which suggest links with older and more western parts of the province (Cawood and Korsch, 2008); (ii) the pre-Delamerian Orogeny Nundora Formation (Teltawongee Group), with a unimodal peak of $1178 \pm 17$ Ma, like the shelf sandstones described above; and (iii) the pre-Delamerian Orogeny Copper Mine Range Formation (Teltawongee 
Group) with peaks between 950-1250 Ma. However, we note that the minimum 950 Ma age is too young for a source in the Musgrave Orogen, and might have been introduced along with the ca 600 Ma peak age zircons (all data from Greenfield et al., 2010, figure 147).

There thus appears to be sources in the Musgrave Province that not only postdate the $c a 500 \mathrm{Ma}$ Delamerian Orogeny (in the Gnalta Shelf samples), but also predate that orogeny as emphasised by the 1100-1200 Ma zircon age peaks in the ca 660 Ma Marino Arkose Member and ca $560 \mathrm{Ma}$ Bonney Sandstone in the upper parts of the Adelaide Rift Complex (Ireland, Flottmann, Fanning, Gibson, \& Preiss, 1998), and by the 1100 and 1164 Ma peak ages in the basal Cambrian (ca 540 Ma) Heatherdale Shale of the Normanville Group (Ireland et al., 1998). All the samples except the Marino Arkose postdate the 530 to 570/580/600 Ma Petermann Orogeny, and are consistent with the idea that the Musgrave Province was exhumed during that deformation. The Marino Arkose implies either earlier exhumation or a source from the Albany-Fraser Orogen farther west.

In the southwestern part of the Thomson Orogen in NSW, inferred equivalents of the Warratta Group reported by Glen et al. (2013) contain detrital zircons in the age range ca 900-1250 Ma. While matching possible sources in the Musgrave Province, these ages are not diagnostic and may alternatively be part of the coupled 500-600 and 1000-1200 Ma Gondwana signature first reported by Ireland et al. (1998) and sourced from farther south along the Gondwana margin. However, detrital, near unimodal 1180 Ma zircons with $\varepsilon_{\mathrm{Hf}}$ values between 0 and +9 occur in sedimentary rocks in drill holes GSQ Macheette1 and HPP Goleburra 1 on the northwestern margin of the Thomson Orogen in Queensland (Brown, Purdy, Carr, Cross, \& Kositcin, 2014). These zircons suggest a Musgrave Province source and thus the presence of an extensive regional transport and depocentre system extending from west to east (Brown et al., 2014).

The 1100-1200 Ma zircons also occur in the Cape River Metamorphics of the Thomson Orogen in north Queensland, but not 1000 km farther north, where there are 1500-1700 Ma zircon ages (Blewett et al., 1998). From the Cape River Metamorphics, Hutton, Fanning, \& Withnall (1998) reported a dominant detrital age of $1145 \pm 21$ Ma ( $95 \%$ of 15 grains) in sandstone, as well as ages of $1238 \pm 58 \mathrm{Ma}$ and $1105 \pm 15 \mathrm{Ma}$ from simple and complex zircons in granite bands in a gneiss. Fergusson, Henderson, Fanning, \& Withnall (2007) reported that 1116-1267 and 1163-1245 Ma zircons dominated two out of three samples from the Cape River Metamorphics, with sample 3 containing a wider range of Mesoproterozoic ages. Both Hutton et al. (1998) and Fergusson et al. (2007) related these Grenvillian populations to sources in the Musgrave Province, suggesting that the province extended much farther east, so that parts either lay beneath or within the northern part of the Thomson Orogen. The 1100-1300 Ma dominant ages in the Bathampton Metamorphics of the Anakie Inlier (Fergusson, Carr, Fanning, \& Green, 2001) also suggest a Musgrave source, perhaps before the inlier was rifted away from the craton (Glen et al., 2013). An alternative is that Musgrave sources lay west of the Thomson Orogen, as discussed above: whether they extended eastwards depends on the nature of 'basement' of the orogen; how much is oceanic and how much is thinned Precambrian continental crust (Glen et al., 2013).

The next part of the paper switches focus to the Lachlan Orogen, firstly examining data from detrital zircon grains in Lower to upper Middle Ordovician turbidites, and then examining possible implications of those data. 


\section{Part Two: descriptions of detrital zircons in Lower-Middle Ordovician turbidites}

\section{Lower-Middle Ordovician turbidites of the Bendigo Terrane}

Two sandstone samples-the Bendigonian sample Ben2 and the Bendigonian-Chewtonian sample Ben5-came from the Castlemaine area, along the rail line between Bendigo and Castlemaine. The upper Middle Ordovician (Darriwilian-Gisbornian) sample Cob1 was collected $65 \mathrm{~km}$ to the southeast (Table 1 ).

\section{Ben2 Castlemaine Group}

Sixty-two zircons were analysed, with $15>10 \%$ discordant. The remaining 47 zircons from sample Ben2 range in age from $c a$ 480-3380 Ma, although the latter grain lies below concordia (Figure 8a, b). Within this range, there is a dominant late Panafrican age population from $c a$ 480-600 Ma (age peaks at 485=551>578 Ma) and a secondary late Grenvillian age population from ca 1020-1060 Ma with peak at $1040 \mathrm{Ma}$ (Figure 8c, d). Other grains occur around $800 \mathrm{Ma}$, from 900-980 (peak at $937 \mathrm{Ma}$ ), 1200-1460 Ma, around 1700 and $2300 \mathrm{Ma}$.

As shown in Figure 8e, the late Panafrican age population contains a group of 5 young grains between $\mathrm{ca}$ 480-500 Ma, containing the 485 Ma peak and having a mean age from all 5 grains of $487 \pm 4$ Ma (Figure A8i in Appendix 1); 14 older grains in the late Panafrican age population are spread between ca 520-590 Ma. They contain the 551 Ma age peak, but no meaningful mean age was obtained using more than 5 grains from the slight plateau between ca 540 and $560 \mathrm{Ma}$.

As shown in Figure 8f, the late Grenvillian age population contains 6 grains between 1020-1060 Ma containing the 1040 Ma peak, and a corresponding mean age from 4/6 grains of $1044 \pm 10$ Ma (Figure A8j in Appendix 1). Figure A8j also shows: (i) 3 grains around $940 \mathrm{Ma}$, containing the peak at $937 \mathrm{Ma}$, and (ii) two grains at ca $960 \mathrm{Ma}$.

Most $\varepsilon_{\mathrm{Hf}}$ values in the late Panafrican age population lie between -0.5 to +2 and -4 to -2 (clusters 2 and 3; Figure 8g, h). Trace element analyses of zircons show derivation from a mixture of sources: alkaline, mafic and granitoids with high $\mathrm{SiO}_{2} . \varepsilon$ values in the late Grenvillian age population lie mainly between +3 to +10 , but 3 grains lie between -12.2 and -4 . Most of these zircons were derived from high-silica granitoids (See Appendix 1 for more detail).

Ben5 Castlemaine Group

Sixty grains were analysed: 4 were $>10 \%$ discordant and rejected. The remaining 56 zircons mostly range in age from 485 to $1300 \mathrm{Ma}$, with one older grain at $1872 \mathrm{Ma}$ lying below concordia (Figure 9a, b). Within this age range, Figure 9 (c, d) shows: (i) a major population between $c a$ 480-660 Ma, with peaks at 546>607>494 Ma; (ii) a peak at 663 Ma representing grains between ca 640-680 Ma (Figure 9d, e); (iii) a lesser population at ca 800-925 Ma (with an obvious peak at $819 \mathrm{Ma}$ ); and (iv) a population between 1000-1150 Ma (mainly late Grenvillian) with peaks at 1017 and $1059 \mathrm{Ma}$. There are older scattered grains at 1200 and $1300 \mathrm{Ma}$, then a gap and a peak at $1872 \mathrm{Ma}$.

The ca 485-660 Ma population is divided into several groups in Figure 9e. The youngest 5 grains, around 480-500 Ma, contain the 494 Ma peak, which corresponds to a mean age from $4 / 5$ grains (omitting the oldest) of $490 \pm 5 \mathrm{Ma}$ (Appendix 1, Figure A9i). The next 22 grains are spread between $c a$ 520-570 Ma, contain the 546 Ma main age peak but do not produce a 
satisfactory weighted mean age. The next 10 grains, between ca 590 and 620 Ma contain the peak of 607 Ma.

The $c a$ 1000-1150 Ma population (Figure 9f) contains: (i) 3 grains between $c a 1000$ and 1040 Ma (with a peak at $1017 \mathrm{Ma}$ and corresponding mean from all 3 grains of $1015 \pm 11$ Ma in Figure A9j in Appendix 1); (ii) 3 grains from ca 1050 to $1060 \mathrm{Ma}$ (containing a peak age of $1059 \mathrm{Ma}$ and corresponding mean from all 3 grains of $1062 \pm 13$ Ma in Appendix 1, Figure A9k); and (iii) scattered older grains.

Most grains in the $c a$ 485-660 Ma population have $\varepsilon_{\mathrm{Hf}}$ values from - 1 to +1.5 (forming part of cluster 3 in Figure 9h) and -5.5 to -2 (forming part of cluster 4 in Figure 9h). The overall spread is -14 to +5.5 . There are more zircons derived from alkaline rocks $>550 \mathrm{Ma}$ than $<550 \mathrm{Ma}$ (Figure 9g, h). In the 1000-1150 Ma population, most $\varepsilon_{\mathrm{Hf}}$ values lie from +4 to +9 , forming cluster 1 in Figure 9h. These zircons were derived from mixed sources. Four grains around 800$925 \mathrm{Ma}$ have $\varepsilon_{\mathrm{Hf}}$ values of 0 to +6 (Figure $9 \mathrm{~g}, \mathrm{~h}$ ).

Cob1 Castlemaine Group

Sixty-one zircon grains were analysed, with $2>10 \%$ discordant and rejected. The remaining 59 zircons range in age from ca 500 to $3200 \mathrm{Ma}$, with one grain at $c a 2300$ lying below concordia (Figure 10a). The age and probability plots show a dominant population between $c a 480$ and $640 \mathrm{Ma}$ (age peaks at $552 \gg 490,617 \mathrm{Ma}$ ) and a secondary (late Grenvillian) population between 950 and $1100 \mathrm{Ma}$ (peak at $1075 \mathrm{Ma}$; Figure 10c, d). Small groups of grains extend from ca 1800 to 3200 Ma (Figure 10c, d).

Figure 10e shows that the ca 480-640 Ma (mainly late Panafrican) population can be subdivided into a number of groups: (i) 5 grains between $c a$ 480-500 Ma contain the peak at $490 \mathrm{Ma}$, which corresponds to a mean age from 4 older grains out of 5 of $493 \pm 6$ Ma (Appendix 1, Figure A10i); (ii) a spread of 5 grains between ca 520-530 Ma; (iii) 11 grains from ca 540-560 Ma, which contain the peak of $552 \mathrm{Ma}$, which corresponds to a mean age from 11 grains of $552 \pm 3 \mathrm{Ma}$ (Appendix 1, Figure A10j); (iv) a spread of 8 grains from ca 560-610 Ma; and (v) 3 grains around 620 Ma producing a peak of $617 \mathrm{Ma}$.

Figure $10 \mathrm{f}$ shows that the late Grenvillian population contains two groups, one with a spread of 5 grains from $c a 950-1050 \mathrm{Ma}$ and a second of 5 grains with less spread around $1070 \mathrm{Ma}$, which contains the peak at $1075 \mathrm{Ma}$ and a mean from all 5 grains of $1078 \pm 9 \mathrm{Ma}$ (Appendix 1, Figure A10k).

$\varepsilon_{\mathrm{Hf}}$ values for the late Panafrican population (Figure $10 \mathrm{~g}$, $\mathrm{h}$ ) are mainly in the range -6 to +3 , with four grains with more negative values; these are derived from granitoids and alkaline magmas. $\varepsilon_{\mathrm{Hf}}$ values for the late Grenvillian population are mainly positive $(0$ to +10$)$ with one grain at -3 and one at -14 ; these zircons are all derived from granitoid magmas.

\section{Comparisons between Bendigo Terrane samples}

The 485-600-(640) Ma late Panafrican population is very similar across all three samples of the Castlemaine Group, with matching 485/494/488 and 551/546/550 Ma age peaks (Figure 11a) across a time interval of $c a 20$ million years. However, the 607 Ma peak age in Ben5 is only close to the 621 Ma peak in Cob1 (which plots inside it). Not surprisingly, the three Bendigo Terrane samples also have matching means of 487-493 Ma with moderate probabilities across a time interval of $c a 20$ million years (Table 2). All three samples also show two main similar Panafrican 
clusters of $\varepsilon_{\mathrm{Hf}}$ values: either (i) low negative values: cluster 3 in Ben2 (-4 to -2 ), cluster 4 in Ben5 $(-5$ to -1.5$)$ and cluster 4 in Cob1 ( -6 to -0.3$)$; or (ii) positive to slightly negative values cluster 2 in Ben2 ( -0.1 to +2.6$)$, cluster 3 in Ben5 $(-0.6$ to +4.6$)$, and cluster 3 in Cob1 $(-1.2$ to +2.1; Figure $11 \mathrm{~b}-\mathrm{d}$ ). In addition, more negative $\varepsilon_{\mathrm{Hf}}$ values occur in Ben5 (cluster $5,-14$ to -10 ) and in Cob1 (cluster 7, -15 and -13; Figure 11b-d). In all three samples, most of these late Panafrican zircons were derived from granitoid rocks, with persistent lesser input from 550-600+ Ma alkaline (and mafic) rocks, with $\varepsilon_{\mathrm{Hf}}$ values from -5 to +5 (clusters 2 and 3 in Ben2, 3 and 4 in Ben 5 and Cob1).

In contrast, the age patterns of these three samples in the ca 950-1100 Ma (late Grenvillian) population do not match as well: the 1040 Ma peak in Ben2, lies between the 1017 and $1059 \mathrm{Ma}$ peaks in Ben5 and is younger than the 1079 Ma peak in Cob1 (Figure 11a). This is also reflected in different mean ages: $1044 \pm 10$ in Ben2, $1015 \pm 11$ and $1062 \pm 13$ in Ben5, and $1078 \pm 9$ Ma in Cob 1 (Table 2; Figures 8-10). Outside of this population, the 937 Ma age peak in Ben2 (which matches the 1040 Ma peak in relative probability) is not matched by a similar peak in the other two samples.

Despite these differences, the $\varepsilon_{\mathrm{Hf}}$ values match reasonably well, with parts of cluster 1 in Ben 2 matching cluster 1 in Ben 5 and cluster 2 in Cob1. Cob1 also contains zircons in cluster 6 with lower positive $\varepsilon_{\mathrm{Hf}}$ values (Figure $11 \mathrm{~b}-\mathrm{d}$ ). Across the 3 samples, the percentages of late Grenvillian zircons derived from high-silica granitoids match, but zircons from other sources are quite variable (Figure 11f). The crustal model ages of the three samples in Table 2 are 1.1-1.7 Ga in Ben2, 1.2-1.7 Ga in Ben 5 and 1.3-1.8 Ga in Cob1 with lesser amounts of 2.2-2.4 Ga continental crust and 0.9-1.4 Ga mantle-derived mafic crust (Table 2; Appendix 3, Figure 11bd). Zircon ages and geochemistry show that this crust was melted at 940-1100 Ma, producing mainly granitoids, and again at 485-640 Ma, producing granitoid and alkaline melts.

In summary, the Panafrican sources are more similar in age, $\varepsilon_{\mathrm{Hf}}$ and trace element geochemistry across time than the Grenvillian sources. This suggests either the same sources were feeding turbidites up to $20 \mathrm{Ma}$ apart, or that an initial source fed the older parts of the Castlemaine Group, which in turn were cannibalised to feed the younger parts of the group. This latter idea fits the propagating thrust model of Foster et al. (1999) and Gray and Foster (1998). However, it is not supported by the variability in the Grenvillian population: (i) the youngest sample Cob1 is derived from older late Grenvillian granitoids than the two older samples; and (ii) the proportion of mafic and alkaline-sourced zircons in the Grenvillian population is highest in Ben5.

\section{Lower-Middle Ordovician turbidites of the Hermidale Terrane}

The Girilambone Group is divided into a lower, chert-poor part (Narrama Formation) and an upper chert-rich part (Ballast Formation; Percival et al., 2011; Burton et al., 2012; Supplementary Papers, Appendix 1).

Mwb1 and Tritton NE, Girilambone Group, Narrama Formation (associated with ca 487 Ma mafic volcanics)

Sixty-one grains from the Mwb1 sample were analysed for $\mathrm{U}-\mathrm{Pb}$ ages: with $9>10 \%$ discordant and thus discarded. The remaining 52 grains range in age from 449 to $2460 \mathrm{Ma}$, with three of the oldest grains lying just below concordia (Figure 12a, b). 
The main feature of the zircon population is a unimodal peak at $497 \mathrm{Ma}$, with a small numbers of older grains (Figure 12c). The $497 \mathrm{Ma}$ peak is represented by 25 grains between $480-500 \mathrm{Ma}$ (Figure 12d), with a corresponding mean age from all 25 grains of $497 \pm 3$ Ma (Figure 12e). Ten older grains define a spread from $c a$ 520-680 Ma with five younger grains define a spread between 440-480 Ma. Based on the constraining zircon U-Pb age of $479 \pm 8 \mathrm{Ma}$ from the Footwall Volcanics (Wan et al., pers.comm.), we suspect that the youngest (449 Ma) zircon has suffered Pb loss. There are very few grains between 950 and $1250 \mathrm{Ma}$ (Figure 12f). A peak at 2451 Ma represents 4 grains.

In the TrittonNE sample, 32 out of 61 grains were $\geq 90 \%$ concordant and used for $\mathrm{U}-\mathrm{Pb}$ analysis. Three of the oldest grains lie just below concordia (Figure 13a). The main population lies between 470-600 Ma (peaks at 497, 581 Ma) and is thus late Panafrican in age. The second population lies between $c a$ 980-1180 Ma (peaks at 1177>1112, 995, 918 Ma; Figure 13b, c). The 918 and $1177 \mathrm{Ma}$ age peaks (and grains $<490 \mathrm{Ma}$ ) lie outside of our average range of late Grenvillian and late Panafrican age grains of 950-1120 and 490-620 Ma, respectively. There is a peak at 2277 Ma.

The late Panafrican age population contains two groups of zircons: 8 grains between $c a$ 470-505 Ma, producing the age peak at $497 \mathrm{Ma}$, and 10 grains between 560-600 Ma producing the peak at $581 \mathrm{Ma}$ (Figure 13c, d). The 915-1200 Ma population (Figure 13e) contains a spread of 10 grains consisting of: (i) 1 grain at $920 \mathrm{Ma}$ (peak at $918 \mathrm{Ma}$ ); (ii) 3 grains spread between $c a$ 980$1020 \mathrm{Ma}$ (peak at $995 \mathrm{Ma}$ ); (iii) 3 grains spread from ca 1070-1120 Ma, containing the peak at $1112 \mathrm{Ma}$; and (iv) 3 grains from $\mathrm{ca}$ 1160-1180 Ma, producing the largest peak at $1177 \mathrm{Ma}$ (Figure 13c, e).

Te2 Girilambone Group, Narrama Sandstone (adjacent to a Lancefieldian-Chewtonian chert)

Sixty-two zircons were used for U-Pb analysis, with two deleted because of discordance $>10 \%$. The remaining 60 grains lie on concordia (Figure 14a, b). Zircons between ca 460 and $3400 \mathrm{Ma}$ contain a major population, at ca 470-620 Ma (with peaks at 560>504, 475, 579 Ma) and a secondary (Grenvillian) population, $c a$ 1000-1180 Ma with peaks at 1031-1049>1153 Ma (Figure 14c,d). Other groups occur around 630-680, 850-930, 1600-1800 and 2000 Ma. Seven grains between 2278 and 2406 Ma contain a significant peak at 2301 Ma (Figure 14d).

The dominant 470-620 Ma population (Figure 14e) comprises: (i) two grains at 471 and 473 Ma, close to the peak at $475 \mathrm{Ma}$, just lying within error of the minimum age of the unit (477-485 Ma; Table 2); (ii) a spread of 13 grains from $c a$ 480-550 Ma, which contains 5 grains around $c a$ 560 Ma producing a 560 Ma peak, with corresponding mean from 5/5 grains of $552 \pm 5 \mathrm{Ma}$ (Figure A14i in Appendix 1); and (iii) 5 grains with a spread from ca 580-620 Ma (Figure 14e).

The secondary 1000-1180 Ma population (Figure 14f) contains: (i) 3 grains at ca $1010 \mathrm{Ma}$ (mean at $1011 \mathrm{Ma}$; Appendix 1, Figure A14j); (ii) a spread of 12 grains from ca 1020-1080 Ma, containing the double peak of 1031-1049 Ma; and (iii) a group of 5 grains from ca 1120 to 1180 Ma, containing the peak at $1153 \mathrm{Ma}$ (Figure 14f).

$\varepsilon_{\mathrm{Hf}}$ values in the $\mathrm{ca} 470-620$ Ma population range mainly from -5 to +2.6 , divided into two clusters (Figure $14 \mathrm{~g}, \mathrm{~h}$ ). In the Grenvillian population, $\varepsilon_{\mathrm{Hf}}$ values lie mainly from +2.5 to +10 (cluster 2) with a few grains from -1.5 to +0.5 (cluster 1, Figure 14g, h). Most grains in both populations are derived from granitoids, with contributions of alkalic melts and a single mafic 
melt in the 470-620 Ma population, and mafic melts in the Grenvillian population. Grains around $2300 \mathrm{Ma}$ are derived mainly from low-silica granitoids, and have $\varepsilon_{\mathrm{Hf}}$ values that straddle CHUR.

Oggyc1 Girilambone Group, Ballast Formation (adjacent to a Darriwilian4 chert)

Concordia and age plots of 53 zircons $>90 \%$ concordant (deleting 8 discordant ones) show a spread of ages between $c a 460$ and $3200 \mathrm{Ma}$ (Figure 15a, b). Figure 15 (c, d) shows that within this range, there is a dominant population between 460-620 Ma (mainly late Panafrican, with age peaks at $577>524,488>462 \mathrm{Ma}$ ) and a secondary population between 980 and $1120 \mathrm{Ma}$ (late Grenvillian, with age peaks of $1062>1000>1115 \mathrm{Ma}$ ). A peak at 850 Ma represents 3 grains at 844-857 Ma.

The late Panafrican population (Figure 15e) contains the following groups: i) 2 grains at 462 and $466 \mathrm{Ma}$, producing the peak at $462 \mathrm{Ma}$, and which provide the best estimate of the maximum depositional age of the sandstone, overlapping with the paleontological age of 461-463 Ma (Table 2); ii) 5 grains at 480-500 Ma that contain the age peak at $488 \mathrm{Ma}$ and corresponding mean age (from all 5 grains) of $491 \pm 5$ Ma (Appendix 1, Figure A15i); a large spread of 22 grains from $c a 520$ to $620 \mathrm{Ma}$, which contain the age peaks of 524 and $577 \mathrm{Ma}$, both of which represent small plateaus within this spread.

The late Grenvillian population (Figure 15f) contains: i) 2 grains from 1000 to $1040 \mathrm{Ma}$, producing the age peak of $1000 \mathrm{Ma}$; ii) 6 grains around $1060 \mathrm{Ma}$, producing the age peak of 1062 corresponding to the mean of $1060 \pm 9 \mathrm{Ma}$, obtained by removing the youngest grain (Figure 15j in Appendix 1); and iii) 3 grains around 1120 Ma producing the age peak of $1115 \mathrm{Ma}$ and with a corresponding mean age from all 3 grains of $1115 \pm 15$ Ma (Figure 15k in Appendix 1).

$\varepsilon_{\mathrm{Hf}}$ values of the Panafrican population extend from -27 to +0.5 , subdivided into several clusters as shown in Figure 15g, h. Most of these zircons are derived from granitoids \pm alkaline \pm mafic rocks. $\varepsilon_{\mathrm{Hf}}$ values of the Grenvillian population extend from -15 to +8.5 , again subdivided into several clusters (Figure 15g, h). With one exception, sources of the Grenvillian grains are granitoids. Grains between 800-950 Ma have $\varepsilon_{\mathrm{Hf}}$ values from -6 to 0 with one exception; they too are derived from granitoids.

Comparisons between Hermidale Terrane samples

All four samples share the dominant $c a$ 470-600 Ma population (Figure 16a1), with three samples showing a very good match of subgroups $<510 \mathrm{Ma}$, with peak ages of 488, 497and 497 Ma and corresponding means of $491 \pm 5$ Ma in Oggyc1 and $497 \pm 3$ in Mwb1 (Table 2). This mean is absent in Te2, which instead has bracketing peaks at 475 and $504 \mathrm{Ma}$. Te2, and Oggyc1 have matching peaks and means around $580 \mathrm{Ma}$. TrittonNE and Mwb1 from the same sequence have matching peaks at $497 \mathrm{Ma}$, but the $581 \mathrm{Ma}$ peak in TrittonNE is only close to the $601 \mathrm{Ma}$ smaller peak in Mwb1. The $\varepsilon_{\text {Hf }}$ plots (Figure $16 \mathrm{~b}, \mathrm{c}$ ) show that both Te2 and Oggyc1 share Panafrican values extending from -8 to 0 . Te2 has additional grains with vaues to +2 , while Oggyc1 has additional grains (part of cluster 2, and clusters 1 and 8 ) with values to -26 . There appears to be little correlation between age and $\varepsilon_{\mathrm{Hf}}$ value in Te2 or in clusters 2 and 5 in Oggyc1, although the very negative grains in clusters 1 and 8 in the latter don't include grains $<500 \mathrm{Ma}$.

The 1000-1100 Ma population is much more significant in Te2 and Oggyc1 than in the other two samples (Figure 16a1), but their peak ages are offset: the double peak of 1031-1049 Ma in Te2, and 1000 and 1062 Ma in Oggyc1. All samples except Mwb1 have small numbers of grains 
between 1100-1200 Ma, with non-matching age peaks at 1115 (Oggyc1), 1153 (Te2) and 1112 and $1177 \mathrm{Ma}$ (TrittonNE). Zircons in the 1000-1200 Ma populations have either positive or zero to negative values of $\varepsilon_{\mathrm{Hf}}$ (Figure $16 \mathrm{~b}, \mathrm{c}$ ).

All samples except Oggyc1 have a small grouping of grains around 2250-2450 Ma (Figures 1215): those in TrittonNE and Te2 overlap within error $(2271 \pm 22,2298 \pm 10$ Ma respectively). The corresponding population in Mwb1 is older with a mean at $2445 \pm 33$ Ma.

Trace element data show that the percentages of zircons derived from high and low-silica granitoids and from alkaline melts in the late Panafrican age population do not vary as much as those in the late Grenvillian age population (Figure 16d, e). Percentages of zircons derived from mafic melts are reasonably consistent across all populations in both samples, whereas those from alkaline melts are more common in the younger population.

An undated sample of quartzite (sample TH1, Fergusson, Fanning, Phillips, \& Ackerman, 2005 from the Girilambone Group $\sim 16 \mathrm{~km}$ north of our Tritton samples) has zircon age peaks at $545>\sim 586>>473 \mathrm{Ma}$, as well as peaks at $c a 2500$ and $2700 \mathrm{Ma}$ (Figure 16a2). Their sandstone sample GG2 $20 \mathrm{~km}$ northeast of our Tritton samples has a very broad peak at $511 \mathrm{Ma}$, with an adjacent shoulder at $c a 535$ and a much smaller one at $570 \mathrm{Ma}$ (Figure 16a2), and almost single grain peaks at $c a 2300$ and $c a 2500 \mathrm{Ma}$. Some of these peaks (eg $586 \mathrm{Ma}$ ) correlate with peaks from our samples (e.g. $581 \mathrm{Ma}$ in TrittonNE and $577 \mathrm{Ma}$ in Oggyc1; $473 \mathrm{Ma}$ with $475 \mathrm{Ma}$ in Te2; and the early Paleoproterozoic to Archean populations).

In summary, the original host magmas of the Hermidale Terrane detrital zircons were mainly 470-600 Ma granitoids \pm alkaline \pm mafic rocks, some $800-1000$ Ma granitoids and 1000-1100 Ma granitoids, all derived from melting mainly Meso-(Paleo)-Proterozoic crust. Significantly, granites derived from Archean crust (2.4-2.7 Ga and importantly, 2.8-3.0 Ga), with a minor 2.42.7 Ga mantle component, were exposed to erosion between the ages of deposition of Te2 and Oggyc1 (see Appendix 1).

\section{The Albury-Bega Terrane}

The two parts of this terrane are separated by the Macquarie volcanic province (Macquarie Arc of Glen et al., 2009) (Figure 1). The western part comprises the turbiditic Pinnak Sandstone (Adaminaby Group) and overlying Bendoc Group in Victoria, and the turbiditic Wagga Group and the overlying Bendoc Group in NSW. The eastern part consists of the turbiditic Adaminaby Group, overlain by the Bendoc Group (Glen et al., 2009). Turbidite packages in the Wagga and Adaminaby groups in NSW contain two major continuous chert units, a lower one of Lancefieldian-Chewtonian age and an upper one of Darriwilian age (Figure 1b), as well as other chert horizons. Correlative chert horizons in the Albury-Bega Terrane west in Victoria were not distinguished during mapping (Glen et al., 2009; Percival et al., 2011).

\section{Lower-Middle Ordovician of the Albury-Bega Terrane west}

Oww5 Wagga Group (adjacent to a probable Chewtonian chert)

Sixxty-one zircons were dated (including rim and core from 2 samples), but 16 grains (including one of the core + rim) were not used, as they were $>10 \%$ discordant. Forty-four grains range from ca 450 to $2800 \mathrm{Ma}$; three grains at 2372, 2767 and 2801 Ma plot below concordia (Figure 14a, b). Within this range, Figure 17 (c, d) highlight a dominant ca 490-620 Ma population (late Panafrican age, with age peaks at 507>530>576 Ma) and a secondary 1000-1120 Ma population 
(almost all late Grenvillian age, with age peaks at 997>1034>1111 Ma). Additional groupings occur at ca 610-700 and 1160-1270 Ma (Figure 17d).

The late Panafrican age population (Figure 17e) contains: i) a spread of 13 younger grains between $c a$ 490-540 Ma that contribute to the 507 and 530 Ma peaks; ii) 3 grains around 580 Ma which contains the 576 Ma peak. The spread of 3 grains from $c a$ 620-660 Ma is not included in the late Panafrican age population.

The late Grenvillian age population (Figure 17f) contains: i) a spread of 12 younger grains from ca 960-1060 Ma, containing the age peaks of 997 and $1034 \mathrm{Ma}$; and ii) 3 grains around $1100 \mathrm{Ma}$ producing the age peak of $111 \mathrm{Ma}$. Three grains at ca 1180-1250 Ma producing the age peaks of 1188 and $1241 \mathrm{Ma}$ (Figure 17f) are not included in the late Grenvillian age population.

$\varepsilon_{\mathrm{Hf}}$ values of the Panafrican zircons range from -14 to +6.5 , with most plotting from -7.5 to +3.5 (Figure 17g). We have subdivided zircons in this latter range into two clusters (Figure 17h, Table 2). Although there are three grains with negative values, most grains in the Grenvillian population have $\varepsilon_{\mathrm{Hf}}$ values from 0 to +10 that we have divided into two clusters (Figure $17 \mathrm{~h}$; Table 2). Most zircons are derived from granitoid melts (Figure 17g, h).

Oww3 Wagga Group (adjacent to a Darriwilian4 chert)

Twenty-two $>10 \%$ discordant grains were discarded from the analysis. Of the 39 zircons, two grains either side of $2000 \mathrm{Ma}$, two grains $2557 \mathrm{Ma}$ and one near $3200 \mathrm{Ma}$ plot just below concordia (Figure 18a, b). Zircons lie between ca 460 and $3200 \mathrm{Ma}$, with a near-continuous spread of ages from ca 460 to $1070 \mathrm{Ma}$, and much fewer zircons >1100 Ma (Figure 18c, d). Within the main age range, the probability plot has a spiky character, with major peaks at 531 , 547, 593 and $1040 \mathrm{Ma}$, and a large number of intermediate, smaller peaks, many of which represent only one or two zircon grains.

The Panafrican age part of this spread (Figure 18e) contains 3 groups of grains from $c a 460-610$ Ma: i) two gains younger than $500 \mathrm{Ma}$. The youngest peaks of 469 and 498 Ma reflect single grains at 468 and $498 \mathrm{Ma}$, with the younger zircon slightly older than the inferred 461-463 Ma paleontological age (Table 2); ii) 4 grains around 540 Ma providing the age peaks of 531 and 547 $\mathrm{Ma}$; and iii) a spread of 5 grains from $c a$ 580-610 Ma containing the age peak of $593 \mathrm{Ma}$.

Four grains around 680 Ma provide the age peak of 686 Ma. Older peaks at 846, 910 and 960 represent 1 or 2 grains.

The older part of this spiky age spread corresponds to a late Grenvillian age population (Figure 18f) and is represented by the age peak of $1040 \mathrm{Ma}$ (Figure 18d) corresponding only to four grains between 1000 and $1100 \mathrm{Ma}$ (Figure 18f). The corresponding poor mean age (4/4 grains) is $1040 \pm 13 \mathrm{Ma} 95 \%$ confidence, MSWD=3.0, probability=0.029) (Figure 18i). Grains > ca 1200 Ma show a scatter of ages to $c a 2000$ Ma.

$\varepsilon_{\mathrm{Hf}}$ values of zircons in the Panafrican age population are mainly -1 to +5.5 , with some more negative (Figure 18g) and are shown as one cluster in Figure 18h. Most of these grains are derived from granitoids. In the late Grenvillian age population, $\varepsilon_{\mathrm{Hf}}$ values range from +5 to +11 , with two more negative values. All are derived from high-silica granitoids. Zircons with ages between 650 and 900 Ma have mainly negative $\varepsilon_{\mathrm{Hf}}$ (between -7 and 0 in clusters 3 and 5), although 3 grains derived from high-silica granitoids have positive $\varepsilon_{\mathrm{Hf}}$ (cluster 2, Figure 18h). 
Comparisons between Albury-Bega Terrane west samples

There are significant differences between the two samples from the Wagga Group. Oww5 contains no zircons with ages between $c a 660$ and 950 Ma (Figure 19a), except for one grain at $829 \mathrm{Ma}$. In contrast, Oww3 has a significant number of detrital zircons with ages between $c a 650$ and $950 \mathrm{Ma}$ (Figure 19a), with peaks at 686, 728, 790, 843 and 910 Ma. $\varepsilon_{\mathrm{Hf}}$ values also differ, mainly because $0 w w 3$ has $\varepsilon_{\mathrm{Hf}}$ clusters 3 and 5 derived from high-silica granites with ages between 650 and $950 \mathrm{Ma}$ (Figure 19b, c). Conversely, the large numbers of grains in Oww5 between 950-1250 Ma (peaks at 997, 1034, 1111, 1188, $1241 \mathrm{Ma}$ ) contrast with the dominant peak at $1040 \mathrm{Ma}$ and a lesser one at $1166 \mathrm{Ma}$ in Oww3. The ca 490-660 Ma population in Oww5 and the $c a$ 460-700 Ma population in 0ww3 are only broadly similar: peaks are mismatched, being older in Oww3, with the exception of the 469 Ma peak (Figure 19a). The spread of 13 grains between ca 490-540 Ma in Oww5 contrasts with only 4 grains in Oww3 (Figures 17 and 18).

By way of comparison, a sample from near the base of the Adaminaby Group near Howqua in central Victoria (sample HQ9 of Fergusson, Nutman Kamiichi, \& Hidaka, 2013) has peaks at 502, 535 and $1038 \mathrm{Ma}$, matching those in both Oww5 and Oww3 (Figure 19a).

Trace element data show that the percentages of zircons derived from the different magma types varies quite markedly (Figure 19 e, f), with the percentage of 'high-silica' zircons higher in the younger sample (Oww3) in both late Panafrican and late Grenvillian age populations.

These data suggest that the sources of the detrital zircons of the Albury-Bega Terrane west underwent a major change with time. Source rocks at the time of deposition of Oww5 consisted of approximately equal proportions of 490-600 Ma and 970-1120 Ma granitoids, which had been melted from largely 1.2-1.7 Ga continental crust. By Oww3, source rocks had changed to dominantly ca 460-950 Ma granitoids and fewer 960-1100 Ma granitoids, melted mainly from 1.2-2.0 Ga crust.

\section{Lower-Middle Ordovician turbidites of the Albury-Bega Terrane east}

In the Albury-Bega Terrane east (Figure 1), samples from four sandstone beds were collected from the Goulburn 1:100 000 sheet (details in Table 1).

Mum1 Adaminaby Group (below a Bendigonian3 chert)

A total of 70 grains were analysed, but 32 were more than $>10 \%$ discordant and were not used for further analysis. The remaining grains lie along or just below Concordia with age peaks from ca 500 to $3529 \mathrm{Ma}$, except for a discordant grain around $2200 \mathrm{Ma}$, and another at ca $1400 \mathrm{Ma}$ (Figure 20a, b). Within this range, the dominant population between ca 480-600 Ma is late Panafrican in age, with peaks at 577, 541 and 494 Ma (Figure 20c, d). Smaller populations occur between $c a$ 800-900 Ma (peaks at 824 and $882 \mathrm{Ma}$ ), between $c a 990-1150 \mathrm{Ma}$ (the late Grenvillian population, with an age peak at $1047 \mathrm{Ma}$ ) and around $1140 \mathrm{Ma}$ (peak at $1141 \mathrm{Ma}$, Figure 20d).

The late Panafrican age population (Figure 20e) contains 3 groups of grains; i) a spread of 6 grains between $c a 480-520 \mathrm{Ma}$, producing the peak at $494 \mathrm{Ma}$; ii) 4 grains at $c a 540 \mathrm{Ma}$, producing the peak age at $541 \mathrm{Ma}$; and iii) 4 grains at ca $580 \mathrm{Ma}$, producing the peak at $577 \mathrm{Ma}$ and the corresponding mean age from all 4 grains of $579 \pm 7$ Ma (Figure 20g in Appendix 1). 
Four grains between 640-680 Ma (peak at $647 \mathrm{Ma}$ ) are not part of the late Panafrican age population,

The late Grenvillian age population (Figure 20f) comprises 6 grains between ca 990-1150 Ma, producing the peak of $1047 \mathrm{Ma}$, with corresponding mean from the 4 oldest grains of $1044 \pm 1$ Ma (Figure 20h in Appendix 1) and two grains around $1150 \mathrm{Ma}$, producing the peak age of 1141 Ma.

Bun8 Adaminaby Group (below a Bendigonian chert)

Out of 60 grains analysed, 13 were $>10 \%$ discordant and were rejected. The remaining 47 grains have ages mainly ranging from $c a 500-2000 \mathrm{Ma}$, with a lone grain at 2684 Ma. One grain at 1858 Ma lies below concordia (Figure 21a, b). Within this range, the dominant population lies from $c a$

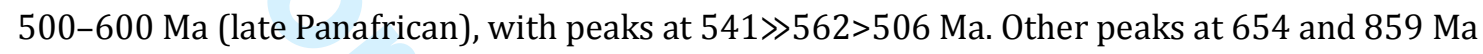
have similar probability to the 1021>1092 Ma peaks in the late Grenvillian 950-1100 Ma population (Figure 21c, d).

The late Panafrican age population (Figure 21e) consists of several groups: i) 2 grains between 500 and $510 \mathrm{Ma}$, producing the peak at $506 \mathrm{Ma}$; ii) a spread of 3 grains from 520-535 Ma; iii) a group of 6 grains around $540 \mathrm{Ma}$, producing the age peak of $541 \mathrm{Ma}$ and corresponding mean from all 6 grains of $542 \pm 5$ Ma (Figure 21i in Appendix 1); and iv) a spread of 6 grains from $c a$ 550 to $590 \mathrm{Ma}$, containing the peak at $562 \mathrm{Ma}$ (Figure 21e).

The smaller late Grenvillian age population (Figure 21f) consists of: i) 4 grains spread from $c a$ 950-980 Ma, producing a peak at $958 \mathrm{Ma}$ (not labelled in Figure 21d); ii) 4 grains around $c a$ $1020 \mathrm{Ma}$, producing the peak at $1021 \mathrm{Ma}$ and corresponding mean from all 4 grains of $1024 \pm 11$ Ma (Figure 21j in Appendix 1); and iii) 3 grains around $1100 \mathrm{Ma}$, producing the peak of $1092 \mathrm{Ma}$. Three separate older grains around 1200 Ma produce the peak at 1205 Ma (Figure 21f): they are not part of the late Grenvillian age population.

$\varepsilon_{\mathrm{Hf}}$ values of the late Panafrican age population lie mainly from -8 to +5 (Figure $21 \mathrm{~g}$ ) and these have been divided into clusters in Figure $21 \mathrm{~h}$. $\varepsilon_{\mathrm{Hf}}$ values of the late Grenvillian age population are mainly positive, from -1 to +8 (which we put into two clusters), with a few outside this range (Figure 21g, h). Grains in both populations are mainly derived from granitoids, although input from mafic rocks occurs in both populations, with alkaline rocks also present in the late Panafrican age population. Grains between 640 and 750 Ma have $\varepsilon_{\mathrm{Hf}}$ values between 0 and +11 , although most lie in cluster 3.

Bun9 Adaminaby Group (above a Bendigonian chert)

A total of 40 grains were analysed, with $20>10 \%$ discordant and thus rejected. Two of the remaining 20 grains lie below concordia, at 620 and 1411 Ma, the latter shown in Figure 22b. There are 2 grains at 258 and $270 \mathrm{Ma}$ (Figure 22d), both of which are far younger than the biostratigraphic age of 475-482 Ma (Table 2). We suspect hydrothermal growth or Pb loss. The $468 \mathrm{Ma}$ grain is also younger than the 475-482 Ma stratigraphic age and we suspect $\mathrm{Pb}$ loss. Most of the remaining 17 concordant grains have ages from $c a$ 520-620 Ma (late Panafrican age population, with peaks at 558》525,612 Ma), peaks at 682 and 781 and then a $1000-1100 \mathrm{Ma}$ (late Grenvillian age ) population represented by a peak at 1069 Ma. Older grains produce the peaks at 1184 and 1509 Ma peaks: there are no older grains (Figure 22c, d). 
Figure 22e shows that the late Panafrican age population consists of: i) a spread of 3 grains from ca 520-540 Ma, producing the peak age of $525 \mathrm{Ma}$; ii) 4 grains at ca $555 \mathrm{Ma}$, producing the peak at $558 \mathrm{Ma}$ and corresponding mean at $557 \pm 7 \mathrm{Ma}$ (Figure 22i); and iii) a spaced spread of 3 single grains from ca 575-625 Ma.

Figure 22c shows that there are only 4 grains between 1000 and $1200 \mathrm{Ma}$. The 3 youngest grains produce a peak age of $1069 \mathrm{Ma}$, coinciding with the mean age from all three of $1070 \pm 13 \mathrm{Ma}$ (Figure 22f).

$\varepsilon_{\mathrm{Hf}}$ values for the Panafrican age population are spread from -21 to +8 (Figure 22g), with 4 forming a cluster from -4 to 0 (Figure $22 \mathrm{~h}$ ). Most are derived from high-silica granitoids. $\varepsilon_{\mathrm{Hf}}$ data are available for only one late Grenvillian grain, a mafic zircon with a value of +6 .

Bun4 Adaminaby Group (adjacent to a Darriwilian4 chert)

Of the 60 zircons analysed, 15 were $>10 \%$ discordant and were not used further. The remaining 45 zircons lie on concordia (Figure 23a, b) and have ages between $c a 500 \mathrm{Ma}$ and $c a 2700 \mathrm{Ma}$ (Figure 23c, d). Within this range there is a dominant population between ca 500-620 Ma (late Panafrican age, with peaks at 591>569»513 Ma) and a much smaller secondary ca 1000-1100 Ma (late Grenvillian age) population with peaks of $1028>1092 \mathrm{Ma}$, each representing only a few grains (Figure 23d). Single grain peaks occur at 732, 1177 and 1240 Ma (not all shown), while the 1932 Ma peak and the double peak of 831 and 852 Ma (not shown) represent 3 grains each. There is a gap in zircon ages from the 1240 Ma peak to the 1932 Ma peak (Figure 23c).

The late Panafrican age population consists of a spread of 24 grains across the population (Figure 23e). Within this spread, there are several groups: i) 5 grains between 501-520 (peak of $513 \mathrm{Ma}$ ); ii) a spread of 4 grains between $c a 540-560 \mathrm{Ma}$; ii) a spread of 13 grains from $c a 560$ $600 \mathrm{Ma}$, with the 569 and 591 Ma peaks reflecting parts of this spread (Figure 23e).

The Grenvillian age population (Figure 23f) is reflected by only 8 grains between $c a 1000-1100$ Ma. It contains: i) 3 grains around $950 \mathrm{Ma}$; ii) 3 older grains spread from ca 1000 to $1050 \mathrm{Ma}$, producing the peak of $1028 \mathrm{Ma}$ (Figure 23f); and iii) 4 older grains between ca 1100-1250 Ma, two of which produce the peak of $1092 \mathrm{Ma}$. The two older grains out of these four are not included in the late Grenvillian age population.

$\varepsilon_{\mathrm{Hf}}$ values in the late Panafrican age population lie between -25 to +3 (Figure $23 \mathrm{~g}$ ). In Figure 23h, we have divided these grains into 4 clusters. Most of these grains are derived from lowsilica granitoids with a contribution from alkaline rocks. $\varepsilon_{\mathrm{Hf}}$ values in the late Grenvillian age population are quite scattered, above and below CHUR, and are granitoid-derived. 6 zircons between 810-1050 Ma have been put into two clusters, one of 4 mafic grains and one low silica granitoid with positive $\varepsilon_{\mathrm{Hf}}$, and a second low-silica granitoid-derived grain, with $\varepsilon_{\mathrm{Hf}}$ close to zero (Figure 23g, h).

Comparisons between Albury-Bega Terrane east samples

Comparisons between samples from the Adaminaby Group are hindered by the lack of $\varepsilon_{\mathrm{Hf}}$ data from Mum 1 and by the presence in Bun 9 of 7 grains between 100 and $300 \mathrm{Ma}$, only 2 of which are concordant, with peaks at 258 and $270 \mathrm{Ma}$. The presence of these Mesozoic ages, either due to crystallisation from hydrothermal fluids or to loss of $\mathrm{Pb}$, complicates comparison with other samples, especially with Bun8, which was collected from the same outcrop, but below an intervening chert bed rather than above. As a result, differences in zircon populations between 
Bun8 and Bun9 might reflect variations in sources, or sedimentary processes, or subsequent fluid activity.

In the $c a$ 500-600 Ma population, Bun4 has asymmetrical peaks, with the highest probability peak (591 Ma) being the oldest (Figure 24). Mum1 has three almost equal-height peaks, whereas Bun8 and Bun9 are approximately symmetrical about a central peak at $541 \mathrm{Ma}$ and $558 \mathrm{Ma}$, respectively. The $\varepsilon_{\mathrm{Hf}}$ plots show that all three samples have clusters in the 500-600 Ma population with $\varepsilon$ values -10 to +5 (clusters 3,4,5 in Bun8 and Bun4; cluster 1 in Bun9; Figure $24 \mathrm{~b}-\mathrm{d}$ ). However, the youngest sample (Bun 4 ) also contains zircons with very negative $\varepsilon_{\mathrm{Hf}}$ values ( -25 to -18 , part of cluster 6, Figure $24 \mathrm{~d}$ ) that do not occur in Bun8, although they overlap with 2 grains in Bun9.

The 1000-1100 Ma population also shows differences between samples. The single peak of 1047 Ma in Mum1 lies between the younger peaks of 1021 and $1028 \mathrm{Ma}$ in Bun8 and Bun4 respectively and the older peaks of 1069 Ma in Bun9 and 1092 Ma in Bun4 (Figure 24a1). The 1141 Ma peak in Mum1 coincides with a dearth of zircons in the other samples. The $\varepsilon_{\mathrm{Hf}}$ data show that clusters 1 and 2 in Bun8 (950-1100 Ma, $\varepsilon_{\mathrm{Hf}}=-1$ to $+3 ; 950-1050 \mathrm{Ma}, \varepsilon_{\mathrm{Hf}}=+5$ to +9 ) are present, albeit less clearly, in Bun4, which also contains more negative values (Figure b-d). Bun8 has minor but significant scattered grains between $c a 500-1500 \mathrm{Ma}$, mainly with positive $\varepsilon_{\mathrm{Hf}}$, derived from primitive mafic \pm alkaline magmas that overlap with a tight cluster of similar 800-950 Ma grains in Bun4.

Other zircon data from the Adaminaby Group in the Albury-Bega Terrane east can be found in the literature (Figure $24 \mathrm{a} 2$ ). In the 'south of Lyndhurst' sample of Meffre et al. (2007), the main 488 and 592 Ma peaks resemble those of Mum1, with the lesser 529 Ma peak close to the 541 Ma one. Older peaks do not match up as well. The Barra Creek and 'south of Oberon' samples are basically unimodal, with peaks at 492 and 497 Ma respectively (Meffre et al., 2007), similar to both the main peak in the 'south of Lyndhurst' sample and the Mum1 494 Ma peak, but different from Bun8, 9 and 4. The Lower Ordovician Melville Point (MVP) sample of Fergusson et al. (2013) has a single peak of 529 Ma (ignoring a peak at 368 Ma younger than the depositional age), which is closest to the unimodal 541 Ma peaks in Bun8 and Mum1. This similarity is enhanced by the 1041 Ma peak in MVP that is close to the 1047 Ma peak in Mum1 (Figure 24a2).

Trace element data show that late Panafrican age mafic, alkaline and high-silica zircons decrease in abundance markedly from Bun8 to Bun4, whereas that of low-silica zircons increases (Figure 24e). The late Grenvillian age population shows approximate constant percentages of low-silica zircons but an increase in low silica ones from Bun8 to Bun4 (Figure 24f).

In summary, the source rocks for Albury-Bega Terrane east samples were mainly ca 480-600 Ma in age, but also $c a 1000-1100 \mathrm{Ma}$, and were derived from granitoid, mafic and alkaline magmas. These melts were extracted from mixtures of $c a$ 1.2-1.8 Ga continental crust and mantle (Table 2). By the time of deposition of Bun4, an additional source was being eroded comprising ca 500-600 Ma granitoids melted from 1.9-2.1 and Archean 2.6-2.9 Ga crust.

\section{Part Three: Terrane Comparisons}

\section{Detrital muscovite data}

Detrital ${ }^{40} \mathrm{Ar}-{ }^{39} \mathrm{Ar}$ muscovite ages are available in some terranes. Muscovite data from two samples were reported by Turner, Kelley, VandenBerg, Foden, Sandiford, \& Flottmann, (1996): 
one sample (Bam) from Lancefieldian turbidites at Bamganie in the Castlemaine Group in the Bendigo Terrane and a second (Har) from pre-Darriwilian turbidites in the Pinnak Sandstone, Adaminaby Group, Albury-Bega Terrane west at Harrietville in central Victoria. Figure 25 shows that the main group (488 to $503 \mathrm{Ma}$ ) of muscovites at Bamganie in the Bendigo Terrane overlap in age with the younger detrital zircons from the Bendigo Terrane, although there is one younger zircon in Cob1 (Figure 25). Older muscovites (507 and $512 \mathrm{Ma}$ ) have no match with our detrital zircons from that terrane. The detrital muscovites in the Albury-Bega Terrane west in the Harrietville (Har) sample have an age gap between 491-502 Ma which is not present in the Bendigo Terrane sample, suggesting differing sources or diachroneity, although the data are few. We have no zircon data from the Albury-Bega Terrane west in Victoria, but the mica ages show only moderate correlation with zircons hundreds of kilometres north in that terrane. Figure 25 also compares these two samples with other detrital muscovite ages: (F) between 490 and 550 Ma from the Stawell and Bendigo zones (Foster et al., 1998); (H26) between 476 and 485 Ma and then 543, 562 and 611 Ma from the Girilambone Group, Hermidale Terrane (Fergusson et al., 2005); and two average ages of 505 and 513 from Mogo, the coastal Adaminaby Group, AlburyBega Terrane east (Fergusson \& Phillips, 2001). These are compared with detrital muscovite ages from mid-Cambrian to Lower Ordovician shallow-water rocks of the Upper Byrd Group in the Ross Orogen (Goodge, Williams, \& Myrow, 2004b) (see below).

Part Three: Discussion: Comparisons and contrasts between turbidite terranesEarlier in this paper we looked at differences and similarities between samples within terranes - intraterrane comparisons. Here we look for similarities and differences between terranes - interterrane comparisons. Are any differences only due to 'noise', or do they have geological significance? Of course, our $\mathrm{U}-\mathrm{Pb}$ and $\varepsilon$ datasets are very small, so any conclusions we may reach are tentative, and may of course refuted, modified or substantiated by future data.

\section{Comparison of $\varepsilon_{H f}$ data}

The $\varepsilon_{\mathrm{Hf}}$ dataset of our samples is particularly useful for making inter-terrane comparisons. Panafrican $\varepsilon_{H f}$ data across all samples (Table 2, Figure 26) show significant changes between the older and younger samples in each terrane except the Bendigo Terrane. In the Bendigo Terrane, Panafrican $\varepsilon_{\mathrm{Hf}}$ values in all 3 samples from Bendigonian (ca 475-482 Ma) to DarriwilianGisbornian (461-463 Ma) form two consistent clusters, one with positive to slightly negative values, and the other with low negative values (Figure 26e-g). In contrast, the other terranes show major changes in Panafrican $\varepsilon$ values between older and younger samples (Figure 26h-l). This is most obvious in the Hermidale Terrane and Albury-Bega Terrane east where late Darriwilian or Darriwilian4 samples Oggyc1 and Bun4 contain additional grains with much more negative values of $\varepsilon_{\mathrm{Hf}}$ down to -25 , in addition to those clusters with positive to slightly negative values like those in the Bendigo Terrane. (In the Albury-Bega Terrane east, the limited number of robust ages from sample Bun9 referred to earlier means we do not know whether the Panafrican $\varepsilon$ values between -20 and -10 represent only a few scattered grains or are 'relics' of a larger population like that in Bun4). The grains with very negative $\varepsilon_{\mathrm{Hf}}$ values in Oggyc1 and Bun 4 (Figure 26d, l) were derived from eroding late Panafrican granitoids, themselves derived by melting early Paleoproterozoic to Archean crust, that were not present in older samples from these terranes (Figure 26c, j). The Albury-Bega Terrane west shows different changes with age: the Darriwilian sample 0ww3 contains more zircons between ca 650-900 Ma than Oww5; a greater proportion of late Panafrican zircons with positive $\varepsilon_{\mathrm{Hf}}$ than Oww5; and fewer late Panafrican zircons with negative $\varepsilon_{\mathrm{Hf}}$ than Oww5. 
Similar but less obvious changes occur in the late Grenvillian population between older and younger samples. Thus, in the Hermidale Terrane and Albury-Bega Terrane east, the Grenvillian zircons in the younger samples Oggyc1 and Bun4 have more negative $\varepsilon$ values than the older samples Te2 and Bun8. Such a change is not apparent in the Bendigo Terrane samples, while in the Albury-Bega Terrane west, the younger Oww3 is lacking the less positive cluster of Oww5 (Figure $26 \mathrm{~h}$, i).

\section{Comparison of different zircon populations (Figure 27)}

The colour coding in Figure 27 allow us to look for patterns in different age populations across all our turbidite samples. The percentages of late Panafrican grains in all the turbidite samples are quite variable both within terranes (an extreme case is in the Hermidale Terrane where it varies from $29.4 \%$ in $\mathrm{Te} 2$ to $71.9 \%$ in TrittonNE) and across terranes (from $61.1 \%$ in Ben5 to $26.3 \%$ in Oww3). However, most of this variation occurs in the Lower Ordovician samples. In the younger (late Middle Ordovician) samples from three of four terranes (Cob1, Oggcy1 and Bun 4 in the Bendigo, Hermidale and Albury-Bega Terrane east), late Panafrican grains consistently constitute $\sim 50 \%$ of zircon, with the Albury-Bega Terrane west (Oww3) being the exception. The percentages of late Grenvillian grains are more constant in the Bendigo Terrane (13.0-18.2\%) and Albury-Bega Terrane east (16.7-23.9\%) than in the other two terranes where they can vary by double. Again, there is mostly less inter-terrane variation in the younger than in the older samples, with Oggyc1 in the Hermidale Terrane being the exception. Early (1121-1250 $\mathrm{Ma})$ Grenvillian grains occupy the smallest percentage in the Bendigo Terrane $(<3.7 \%)$, and are higher in the rest $2.09 .8 \%$ in Hermidale Terrane; $5.29 .1 \%$ in Albury-Bega Terrane west and 5.68.7\% in Albury-Bega Terrane east). The ratio of late Panafrican to late Grenvillian grains is highest in the Hermidale Terrane (between 1:1 and 7.3:1) compared to the others (between 1.2:1 and 1.7:1 in Albury-Bega Terrane west, 2:1 and 4.7:1 in Bendigo Terrane, between 1.5 and 2.9:1 in Albury-Bega Terrane east).

In summary, the only patterns we can discern are the greater uniformity of numbers of late Grenvillian grains in the Bendigo Terrane and the greater inter-terrane variability of most populations in the Lower Ordovician compared to the late Middle Ordovician samples.

\section{Source magmas}

Identification of source magmas is based on the empirical geochemistry of zircons that crystalled from different melt compositions (Belousova et al., 2002). Differences between the source magmas of the youngest zircons have been discussed above, with reference to Figure 25, which shows different geochemistries of the youngest grains in each terrane.

Panafrican age populations in the Bendigo and Hermidale terranes have a more constant percentage of zircons derived from high-silica granitoids than in the other two terranes (Figure 28a). In the Albury-Bega Terrane east, it is the Grenvillian age population that has the more constant percentage of high-silica zircons (discounting the data-poor Bun9 as previously suggested). Bendigo Terrane samples have the highest and most constant ( 18-25\%) percentage of alkaline-magma ('alkaline') late Panafrican age zircons (Figure 28a), followed by the Hermidale Terrane ( $\sim 15 \%)$. The Hermidale Terrane samples have a higher, less varied population of late Panafrican age zircons derived from low-silica granitoids than the other terranes. This also contrasts with the Grenvillian population (Figure 28b) from the same terrane that is dominated by high-silica zircons. In the Albury-Bega Terrane west, high-silica zircons 
increase upsection, matched by a decrease in low-silica ones in both late Panafrican and Grenvillian age populations

Most of the detrital zircons are derived from granitoid rocks, and Grenvillian zircons from highsilica granitoid are generally more numerous than those from low-silica granitoid. The same applies for Panafrican zircons in the Bendigo Terrane, but in other terranes, Panafrican zircons from low-silica granitoids are more numerous in 5/7 samples (exceptions are Oww3 and Bun9). Minor contributions from mafic rocks (Figure 28) are more common in older samples than the younger ones in both Panafrican and Grenvillian populations, except for the Panafrican population in the Hermidale Terrane, with those in the Bendigo Terrane the youngest of all (Figure 25), and those from Bun8 the most numerous. Alkaline zircons are relatively rare in the Grenvillian population (except in Ben5) and mafic zircons are also relatively rare (except Bun8, Bun9 and to a lesser extent Ben5).

\section{$\mathrm{U}-\mathrm{Pb}$ plots -475-530 Ma}

Figure 25 compares zircons between 475-530 Ma and illustrates some mismatches in populations at different times. The gap in zircons in the Bendigo Terrane from 501-510 Ma is not matched in the other turbidite terranes, but all of these have a gap between 510-515 Ma, bar two grains. Zircons in Bun8, 9, 4 in the Albury-Bega Terrane east are not as young as those in other terranes, although Mum1 in Albury-Bega Terrane east overlaps with them, pointing to variation in Albury-Bega Terrane. In contrast, the age distribution of detrital zircons in the two oldest (and nearby) samples in the Hermidale Terrane, TrittonNE and Mwb1, are very similar, pointing to reproducibility in our sampling.

Comparisons of 400-1600 Ma and 400-700 Ma probablity plots across the four Ordovician turbidite terranes are shown in Figure 29. The youngest samples across the four Ordovician turbidite terranes (Figure 29, column1) show mismtaches between 700-950 Ma and in the Panafrican and late Grenvillian age populations. The age gap between 950-700 Ma in Cob1 (Bendigo Terrane) contrasts with more grains in Oggyc1 and Bun4 and with many more grains in Oww3. In the late Panafrican age population, the central age peak with symmetrical 'wings' in Cob1 differs from the asymmetrical age distributions in Oggyc1 and Bun4, with older ages more common in both. This age population is also symmetrical in Oww3, but in contrast to Cob1, there are two flanking peaks about a central age gap at $563 \mathrm{Ma}$. In the late Grenvillian age population, both Cob1 and Oww3 show asymmetrical peaks, with the older grains more numerous. Oggyc1 appears symmetrical, whereas in Bun4 the older grains are more common than the older ones (column 1, Figure 29). Diffferences are also apparent between the older samples (column 2, Figure 29). Oww5 shows clear asymmetry with younger ages dominant in the late Panafrican and late Grenvillian age populations. Relations are more complex in the Albury-Bega Terrane east. Bun8 is symmetrical in both populations, Mum1 is symmetrical in the late Panafrican, whereas Bun9 is asymmetrical with older ages more common. Column 4 in Figure 29 shows that the probability plots from the Bendigo Terrane possess a central peak at ca 540-550 Ma and valleys at 510 and 590-600 Ma, with outer peaks at 490 and 360-600 Ma. In contrast, most other samples contain peaks at or near 500 Ma and 580-590 Ma. The two samples from the Albury-Bega Terrane west possess a valley at $560 \mathrm{Ma}$, and peaks at 500, 530 (a double with 545 Ma in 0ww3) and 580-590 Ma. Three samples from the Hermidale Terrane have broad valleys between 520-550 Ma (but not Te2). In Albury-Bega Terrane east, three samples have peaks at $540 \mathrm{Ma}$, with the other (Bun9) at $560 \mathrm{Ma}$. 
Figure 29 columns 2 and 3 also contrast the 1180 and 1177 Ma age peaks from two samples on the Gnalta Shelf with plots from the Ordovician turbidites.

In attempting to summarise these comparisons, we note $\mathrm{U}-\mathrm{Pb}$ age peak variability within similar age samples in some terranes, and consistency in others. We also note that we can match individual age peaks across some terranes. However, when we compare all our data- $\mathrm{U}-\mathrm{Pb}$ plots, Hf plots and trace element source magma-we find differences, especially in the upper Middle Ordovician samples. We also cautiously suggest that the Bendigo Terrane samples have differences with those from other terranes. Differences between old and young also samples occur in all but the Bendigo Terrane. Such differences, indicating changing sources with time, are consistent with the findings of Bruce and Percival (2014) on the changing sources of clay-sized material in the Lower and upper Middle Ordovician chert packets in the Girilambone Group (Hermidale Terrane) and the Adaminaby Group (Albury-Bega Terrane east). For instance, the difference in zircon populations between Bun8 and Bun9 across one chert interval may either be random, or may reflect the sort of changes seen by them across this time interval.

\section{Part Four: Possible source areas for the Ordovician turbiditic sandstones}

\section{Constraints}

Sources of the Lachlan Ordovician turbidites singly or together supplied:

1. a dominant population of late Panafrican (490-620 Ma) zircons, with a wide range of positive to negative values of $\varepsilon_{\mathrm{Hf}}$, mixed with a secondary population of late Grenvillian (950-1120 Ma) zircons with mainly positive values of $\varepsilon_{\mathrm{Hf}}$;

2. very small percentages of Archean, and Paleo- and early Meso-proterozoic zircons

3. a small population of early Grenvillian grains (1121-1250 Ma), $<3.7 \%$ in Bendigo Terrane and $<9 \%$ in the others (see later, Figure 32 );

4. zircons derived from 500-800 Ma mafic and alkaline rocks, possibly rift-related;

5. some differences in Panafrican age zircon patterns and $\varepsilon_{\mathrm{Hf}}$ patterns between samples in the Bendigo Terrane and those in other terranes (see part 4);

6. detrital muscovite grains, mainly from metamorphic sources, with ages from 478-515 Ma, but some up to $611 \mathrm{Ma}$; and

7. very negative $\varepsilon_{\mathrm{Hf}}$ zircons in upper Middle but not Lower Ordovician sandstones in the Hermidale and Albury-Bega east terranes, sourced from 485 to $615 \mathrm{Ma}$, low-silica granitoids derived by Panafrican melting of lower Paleoproterozoic-Archean crust.

An early paper (Packham, 1969) suggested several possible sources of the Ordovician turbidites: i) rocks of the Adelaide Rift Complex deformed in the Delamerian Orogeny; ii) the Amadeus Basin of central Australia; or iii) shallow-water Ordovician rocks in western Tasmania. Cas, Powell, \& Crook (1980) favoured mixed sources from western Tasmania in the south and from cratonic Australia in the west (our Delamerian Orogen: note they thought the turbidites were Upper Ordovician, the prevailing view prior to Glen et al., 1990). In contrast, Wyborn, Chappell, \& Wyborn (1979) first used an analogy with the Robertson Bay Terrane in the Ross Orogen to suggest that similar age rocks underlay Ordovician turbidites of the Lachlan Orogen. Subsequent workers suggested sources from the Delamerian Orogen of South Australia or combined sources from the approximately coeval Delamerian mountains (Turner et al., 1996) plus the Ross Mountains/Orogen of Antarctica (e.g. Coney, Edwards, Hine, Morrison, \& Windrim, 1990; Fergusson et al., 2013; Glen, 1993; Gray and Foster, 2004; Offler and Fergusson, 2016; VandenBerg and Stewart, 1992). Offler and Fergusson (2016), who used sediment geochemistry 
to suggest a Delamerian Orogen source in the Lower and Middle Ordovician and a possible East Antarctic source in the Upper Ordovician or from within East Antarctica (e.g. Wilkes Land; Veevers et al., 2006; or from the East African Antarctic Orogen \pm Gamburtsev Subglacial Mountains; Veevers, 2015). Williams, Chappell, Crook, \& Nicoll (1994) were impressed by the homogeneity of zircon patterns in the Ordovician turbidites and proposed an origin along the proto-Pacific margin of East Gondwana (Williams \& Pulford 2008; Williams, Goodge, Myrow, Burke, \& Kraus, 2002), which they then in turn sourced back to the Panafrican Mozambique belt (see also Squire, Campbell, Allen, \& Wilson, 2006c for the model of Transgondwanan Supermountain).

We first consider possible Australian sources, then Antarctic ones. Because our data suggest that Australia sources did not contribute significantly to the zircon populations in the Lachlan Ordovician turbidites, we provide only brief discussion in the main text on these possible sources with more information in Supplementary Papers (Appendix 1).

In addition to comparing $\mathrm{U}-\mathrm{Pb}$ ages, we have tried to compare our $\varepsilon_{\mathrm{Hf}}$ data with that in the literature. However, most potential source lithologies have published whole rock $\varepsilon_{\mathrm{Nd}}$ rather zircon $\varepsilon_{\mathrm{Hf}}$ data, and we have been only able to find six measurements of de facto Ordovician turbidites from the Lachlan Orogen, two (-9.2 and -8.3) from the very S-type Cooma Granodiorite, regarded as virtually in situ, melted Ordovician sedimentary rocks (McCulloch and Chappell, 1982) and four $(-10.5,-9.9,-9.7,-9.5)$ from inferred Ordovician hosts to the Bega and Berridale batholiths (McCulloch and Woodhead, 1993). As a result, we have used equations from Vervoort, Patchett, Blichert-Toft, \& Albarède (1999) to convert published $\varepsilon_{N d}(i), \varepsilon_{N d}(t)$, or $\varepsilon_{N d}$ data to $\varepsilon_{\mathrm{Hf}}(\mathrm{i})$ and $\varepsilon_{\mathrm{Hf}}(\mathrm{t})\left(=\varepsilon_{\mathrm{Hf}}\right)$ data. Vervoort et al. (1999) recognised several linear arrays between Lu-Hf and Sm-Nd isotopic systems: a crustal array for sediments, continental basalts, granitoids and juvenile crustal rocks of $\varepsilon_{\mathrm{Hf}}=1.34 \times \varepsilon_{\mathrm{Nd}}+2.82$ (equation 1); and the one we have mainly used here, for passive margin sediments derived from evolved sources, of $\varepsilon_{\mathrm{Hf}}=1.83 \times \varepsilon_{\mathrm{Nd}}$ +0.60 (equation 2). Using this calculation to compare published whole rock granite or sandstone $\varepsilon_{\mathrm{Nd}}$ data with our zircon $\varepsilon_{\mathrm{Hf}}$ data can only provide approximations as comparisons between whole-rock $\mathrm{Nd}$ data and zircon $\mathrm{Hf}$ data can be uncertain. Key points are what minerals in the rock carry the $\mathrm{Nd}$, and what their ages are. In comparing the Lachlan data in Table 2 with source data in Tables 3-6, summarised in Figures 31 and 32, we try to match age for age: thus in Figure 32, the key matches are Panafrican age zircons with Panafrican granites or events and Grenvillian age zircons with Grenvillian intrusions or events. Finally, in using published model age data, we note that that different isotope ratios and different calculations (one stage or two stage) may have been used to arrive at the final model age that precludes possible Australian sources within the Albany-Fraser Orogen, Pinjarra Orogen and volcanics in the Delamerian Orogen and Lachlan Orogen

In the Supplementary Papers (Appendix 1) and Table 3 we consider possible Australia sources, some of which have been postulated as sources by papers cited in Appendix 1. Many of these locations are shown in Figure 30. Figure 25 compares ages of potential sources in the Lachlan Orogen and Delamerian Orogen with the 475-530 Ma populations in the turbidites. Figure 31 compares our 400-1600 Ma U-Pb probability density plots with 400-1600 Ma from a wide range of possible Australia and Antarctic sources. Figure 32 does the same for $\varepsilon N d$ and $\varepsilon$ data, with the treatment of data discussed above. 


\section{The Albany-Fraser and Pinjarra orogens}

The dominant (490-620 Ma) and secondary (950-1120 Ma) detrital zircon peaks in the Ordovician turbidites rule out sources in the Albany-Fraser Orogen along the south coast of Western Australia, which is characterised instead by: i) the widespread presence of 1260-1345 Ma felsic intrusions; ii) the presence of 1650-1710 intrusions, commonly carrying older zircons; iii) an absence of intrusions around 950-1100 Ma; and iv) an absence of 480-600 Ma zircons, even though the southwestern margin of the orogen was deformed at 500-550 Ma, as summarised by Fitzsimons (2003).

Similar arguments also rule out the northern part of the Pinjarra Orogen along the west coast of Western Australia, where there is a major population of 1100-1900 Ma zircons, and an absence of 500-550 Ma magmatism The Leeuwin Complex in the southern Pinjarra Orogen does contain 1000-1200 Ma (dominantly ca $1090 \mathrm{Ma}$ ) and 650-800 Ma zircons from orthogneiss, intrusions at $540 \mathrm{Ma}$ and metamorphic rocks at 500-550 Ma, while lacking zircon >1200 Ma. The very small size of this crustal block precludes it as a major source for the Lachlan turbidites, but the Antarctic extensions of these rocks are a potential source (see below).

\section{Ordovician and Cambrian volcanic rocks of the Lachlan Orogen and Delamerian Orogen}

At the other end of the time scale, ages and trace-element geochemistry of the youngest detrital zircons in our samples ( $<530 \mathrm{Ma}$; Figure 25) rule out major input to the Panafrican population only from 490-514 Ma Cambrian-Ordovician volcanic sources in the Delamerian Orogen and Lachlan Orogen. Precluded as major sources are:

(i) The oldest (?480-490 Ma; Percival and Glen, 2007) volcanics of the Macquarie Volcanic Province in the Lachlan Orogen (mvp, Figure 30) because they are too young and because zircons with this age are not significant in turbidites of the Albury-Bega Terrane flanking these volcanics.

(ii) Three younger (ca 498-505 Ma) correlative Cambrian volcanics in the Delamerian and Lachlan orogens. The ca 499-505 Ma Mount Read Volcanics in west Tasmania (DO south of the Australia mainland, Figure 30) are mainly andesites and basalts with $\varepsilon_{\mathrm{Nd}}$ values of -2.2 to +1 , converted to $\varepsilon_{\mathrm{Hf}}$ values of -0.1 to +4.2 using equation 1 above from Vervoort et al. (1999). Less common rhyolites and dacites have $\varepsilon_{\mathrm{Nd}}$ values of -9.1 to -1.9 (converted to $\varepsilon_{\mathrm{Hf}}$ values of -9.4 to +4.4 , with all $\varepsilon_{\mathrm{Nd}}$ data from the summary of Corbett and Vicary, 2014). Correlative ca 495-502 Ma, Jamieson and Licola volcanics from the basement Selwyn Block in the Lachlan Orogen (SB, Figure 30) outcrop as the Mount Wellington Fault Zone and are mainly andesitic (VandenBerg et al., 2000). The correlative ca 499-507 Ma Mount Stavely Volcanic Complex (Crawford, Donaghy, Black, \& Stuart-Smith, 1996) in DO in western Victoria is mainly an andesitic breccia with a local dacite near the top. We preclude major input from all three units because our data (Figure 25) record only two detrital 'mafic' zircons in the Lachlan Ordovician turbidites, one with negative $\varepsilon_{\mathrm{Hf}}$ and with one positive. Most detrital zircons of this age are derived from high-silica granitoids, with mainly negative $\varepsilon_{\mathrm{Hf}}$ (Figure 25), restricting any possible input to the more felsic volcanics. Significant input is not surprising since these volcanics developed in generally submarine settings. 
(iii) Older Cambrian (mafic and ultramafic) volcanics in the Delamerian Orogen of west Tasmania, locally eastern South Australia, and in western Victoria. These include mafic-ultramafic complexes $\geqslant 514$ Ma in west Tasmania (with $\varepsilon N d-3$ to +3.7 ; Brown and Jenner, 1989, converted to $\varepsilon_{\mathrm{Hf}}$ values of -1.2 to +7.8 using equation 1 of Vervoort et al., 1999), ca 522 Ma rift volcanics in the Delamerian Orogen in eastern South Australia, ca 515 Ma basalts of the Stawell volcanics at Stawell in the western Lachlan Orogen, and 510-?525 Ma arc rocks in western Victoria. We preclude major input from these units because there is only one detrital zircon at 514 Ma in the Lachlan Ordovician turbidites, because four out of five mafic zircons in this age range have more negative $\varepsilon_{\mathrm{Hf}}$ values than those in west Tasmania, and because there is an age gap in detrital zircon ages in the Lachlan Ordovician turbidites from 510-515 Ma, and up to $517 \mathrm{Ma}$ in the closest turbidites, those of the Bendigo Terrane (Figure 25).

\section{Granitoids of the Delamerian Orogen in West Tasmania}

Granitoids of the Delamerian Orogen are also possible sources. Little is known about their distribution in west Tasmania, but the 498 Ma S-type South West Cape Granite contains a large number of xenocrystic zircons with ages between 1500-1700 and $c a$ 1720-1880, with neither present in large numbers in the Ordovician turbidites (Table 3, Figures 25 and 31). The 499 Ma Itype Elliott Bay Granite is too young to have supplied many zircons, since Black, McClenaghan, Korsch, Everard, \& Foudoulis (2005) reported an absence of xenocrysts. Parenthetically, the Proterozoic sedimentary rocks of western Tasmania are also unlikely sources because of their predominant 1650-1800 and 1400-1450 Ma detrital zircons (Black, Calver, Seymour, \& Reed, 2004).

\section{Granitoids of the Delamerian Orogen in South Australia and Western Victoria}

Granites from the South Australian part of the Delamerian Orogen (DO, Figure 30) comprise 490-514 Ma foliated, syn-tectonic and 480-490 Ma post-tectonic intrusions (Foden et al., 2002). The oldest granites are like the Rathjen Gneiss, and were probably generated by melting of the host Kanmantoo Group (Foden, Sandiford, Dougherty-Page, \& Williams, 1999). Available U-Pb zircon ages and $\varepsilon_{\mathrm{Hf}}$ and model age data are listed in Table 3, and shown in Figures 25, 31 and 32.

The 480-514 Ma age range of these granites overlaps with the ages of our youngest detrital zircons (Figure 25). Foden et al. (2002) provided $\varepsilon_{\mathrm{Nd}}(\mathrm{i})$ values of -10.5 to +1.8 for I -type granites, -13.7 to -8.1 for S-types and mainly -12.89 to -12.0 for porphyritic I-S granites. These convert to $\varepsilon_{\mathrm{Hf}}$ values of -19 to $+4,-25$ to -15 , and -23 to -21 , respectively using the Vervoort et al. (1999) equation discussed earlier. The corresponding model ages are $0.82-2.08$ Ga for the Itypes, 2.15-2.36 for the S-types and 1.33-2.39 for the I-S types (Figure 32). However, we do not think that these granites are the main sources for the 490-600 Ma detrital zircon population because: i) most of their ages are too young ( $<514$ Ma; Figures 25 and 31); ii) Foden et al. (1999) recorded xenocrystic cores with peaks of 550-675, 900-1100, ca 1250, ca 1950-2200 and ca $2500 \mathrm{Ma}$, but not individual grains between 900-1100 Ma; and iii) the distinctly negative values of $\varepsilon_{\mathrm{Nd}}(\mathrm{i})$, and $\varepsilon_{\mathrm{Hf}}$ values of -25 to -4 , calculated from Foden's data using the second equation of Vervoort et al. (1999), show only minimal overlap with the $\varepsilon_{\mathrm{Hf}}$ values of mainly -5 to +2 and also -15 to -10 from late Panafrican detrital zircons in turbidites of the Bendigo Terrane (those geographically closest to the Delamerian granites) (Table 2; Figure 32). The additional western Victorian data of Kemp, Hawkesworth, Collins, Gray, \& Blevin (2009), shown in Table 3 and labelled (K) in Figure 32 also preclude their S-types, 515 Ma I-types and 510 Ma I-types as 
potential sources, since their overall $\varepsilon_{\mathrm{Hf}}$ range ( -21 to -3$)$ is also in general too negative. Some 495 Ma I-types, however, have calculated $\varepsilon_{\mathrm{Hf}}$ values that overlap with zircons in Ordovician turbidites, and one individual I-S, and two I type granites have spot $\varepsilon_{\mathrm{Hf}}$ values that lie within the range.

\section{Kanmantoo Group of the Delamerian Orogen}

The Kanmantoo Group was deposited in a backarc rift from ca 514 to 522 Ma (Flöttman, Haines, Jago, James, Belperio, \& Gum, 1998a; Foden, Elburg, Dougherty-Page, \& Burtt, 2006). Ireland et al. (1998) showed that rifting was accompanied by a major change in zircon populations from the older passive-margin Adelaide Rift Complex, with the incoming of a Panafrican zircon population ( $\sim 500-650 \mathrm{Ma})$ and a smaller Grenvillian population $(\sim 900-1200 \mathrm{Ma})$. The Panafrican and Grenvillian zircons were probably derived from Antarctica (Ireland et al., 1998). The similarity of these populations to those in the Lachlan Ordovician turbidites led Turner et al. (1996) to suggest that the Kanmantoo Group, which was exhumed in the Delamerian Orogeny, provided sources for Ordovician turbidites of the Lachlan Orogen.

We examine this by using the $\varepsilon_{\mathrm{Nd}}$ data from the Kanmantoo Group of Haines, Turner, Foden and Jago (2009), using only their sandstone data for comparisons with Ordovician sandstones of our study. Haines et al. (2009) recorded $\varepsilon_{\mathrm{Nd}}$ sandstone values of -9.6 and -9.3 in the Carrickalinga Formation, -9.6 and -9.9 in the lower to middle Backstairs Passage Formation, the two together comprising the lowest $\sim 1600 \mathrm{~m}$ of the Kanmantoo Group. More negative $\varepsilon_{\mathrm{Nd}}$ values occur in sandstones in the upper $\sim 5600-7100 \mathrm{~m}$ of the group: -12 in the upper Backstairs Passage Formation, -11.2 in the Talisker Calc-Siltstone, -16.2 and -14.6 in the Tapanappa Formation and -14.6 in the Balquidder Formation, not including -13.7 from the Middleton Sandstone, the stratigraphic position of which is uncertain (thicknesses are from Flöttmann et al., 1998a). Only the $\varepsilon_{\mathrm{Nd}}$ values of -9.9 and $\mathbf{- 9 . 3}$ from the lower part of the Kanmantoo Group overlap with the Cooma and Bega Lachlan Orogen data, $\varepsilon_{\mathrm{Nd}}$ data (-8.3, -9.2; and -9.5, -9.7, -9.9, -10.5, respectively). Since we do not know of any $\varepsilon_{\mathrm{Nd}}$ from the Bendigo Terrane (nearest Lachlan Ordovician turbidites to the Kanmantoo Group), we have converted $\varepsilon_{\mathrm{Nd}}$ data from Kanmantoo Group into $\varepsilon_{\mathrm{Hf}}$ values (-17.0 and -16.4 for the lower part and -29.1 to -19.9 for the upper part) that can be directly compared with our measured late Panafrican zircon $\varepsilon_{\mathrm{Hf}}$ data from the Bendigo Terrane - approximately -1 to +2 and -15 to -10 . There is little correlation, suggesting little input from the Kanmantoo Group into the Lachlan Ordovician turbidites.

Turner et al. (1996) suggested that exhumation of the Kanmantoo Group in the Delamerian Orogen at $c a 500$ Ma shed detritus eastwards into the Ordovician turbidites of the Lachlan Orogen. Several structural studies in the western margin and best outcropping part of the Kanmantoo Group, south of Adelaide in the Fleurieu Peninsula (overlapping in space with most of the igneous samples used by Turner et al., 1996) suggest, however, that most products of exhumation would have been shed westwards instead. Flöttmann and James (1997) showed that the Kanmantoo Group, and underlying Normanville Group and Adelaidean rocks in Fleurieu Peninsula, were deformed by the Delamerian Orogeny into a west-verging thrust belt, generally by the reverse reactivation of an east-dipping set of normal faults. Flöttmann et al. (1998b) suggested that the resultant foreland basin, the repository of off-shed detritus, lay west of the Fleurieu Peninsula beneath Gulf St Vincent. In the absence of a detachment fault below the Kanmantoo Group, exhumation and erosion of lower Kanmantoo Group ( 1600 m thick) would likely involve liberation of dominant Grenvillian and older zircons from the underlying Normanville Group and also the dominant 1000-1800 Ma zircons of the underlying older 
Adelaide Rift Complex (zircon data of Ireland et al.,1998). These old zircons are uncommon to rare in the Lachlan Ordovician turbidites. Of course, structural relations in the equivalent, largely buried eastern margin of the Kanmantoo Trough in western Victoria might be different. However, Cayley et al. (2011) used deep seismic reflection data to infer (surprisingly) a dominantly east-dipping thrust system with some west-dipping back thrusts. In such a structural setting, detritus there too would have been largely shed to the west.

Thus, using available data, we do not concur with Turner et al.'s (1996) interpretation that Lachlan Ordovician turbidites were derived from exhumation of the Kanmantoo Group in eastern South Australia.

\section{Possible Antarctic sources excluding the Ross Orogen}

Data from outcrop along the coast, in near coastal mountains and along the Transantarctic Mountains indicate that geology of East Antarctica (Table 4) consists of:

1. Archean to Paleoproterozoic cratons

2. 900-1350 Ma Grenvillian age belts, many of which show signs of reworking in Panafrican times

3. Panafrican belts that commonly contain relics of Grenvillian tectonics

4. The Ross Orogen is preserved in the $\sim 3500 \mathrm{~km}$ long Transantarctic Mountains. The orogen is built above basement representative of unit 1 , and consists of a mid-upper Neoproterozoic passive margin phase and a mainly Cambrian to Lower Ordovician convergent margin phase (Harley, Fitzsimons, \& Zhao, 2013).

5. Younger units, which include Devonian and Permian-Triassic sedimentary rocks developed inland of the Upper Devonian to Carboniferous and Upper Carboniferous to lower Mesozoic continental margin arcs located in West Antarctica before Gondwana breakup (e.g. Elliott, 2013).

Relevant to this paper are belts of Grenvillian magmatism and metamorphism and Panafrican magmatism and metamorphism in East Antarctica.

Grenvillian and Panafrican belts In East Antarctica

Three belts of Grenvillian magmatism and metamorphism, labelled G1, G2 and G3 in Figure 30, correlate with previously contiguous Grenvillian basement in Australia, India and southern Africa. G1 comprises the Windmill Islands and Bunger Hills (WI and BH, respectively, Figure 30) and is an extension of the Albany-Fraser Orogen in Australia (AF, Figure 30). G1 is characterised by early granites from 1315 to $1342 \mathrm{Ma}$ with protoliths to $1700 \mathrm{Ma}$, followed by 1150-1214 Ma granites and limited 500 Ma deformation. Most of these bodies are too old to have sourced zircons in the Lachlan Ordovician turbidites. Nd model ages from 1.9-3.2 and 1.1-2.3 Ga (Table 4, Figure 32) are older than most of the Hf model ages indicated by the Ordovician zircons.

G2 is the Rayner Complex of Enderby, Kemp and MacRobertson lands and the northern Prince Charles Mountains, where they are divided into a northern Beaver Terrane and southern Fisher Terrane (RY and NPC, respectively, Figure 30). The Rayner Complex is an extension of the Eastern Ghats of India (EG, Figure 30). A defining feature is the dominant period of magmatism and metamorphism at 900-990 Ma, known as the Rayner Structural Episode that reworks older 
mafic and felsic protoliths with ages between ca 1020 and 1400 Ma (Mikhalsky et al., 2013; Table 4). While the younger intrusions could be sources of zircons in the Lachlan Ordovician turbidites, only the Fisher Terrane matches the mostly juvenile $\varepsilon_{\mathrm{Hf}}$ values of this population. This terrane, however, is too narrow to have sourced the Lachlan Ordovician turbidites, unless extensions of it under the ice are substantially larger.

G3 occurs as the Maud Belt in Western Dronning Maud Land and is part of the East African Antarctic Orogen, lying adjacent to southern Africa in Gondwanan reconstructions (WD, Figure 30). This belt is dominated by $1100-1170$ Ma felsic to mafic volcanic rocks overprinted by 1030-1100 Ma granitoid magmatism and granulite facies metamorphism (Harley et al., 2013; Jacobs et al., 2015). It is largely made up of juvenile Mesoproterozoic crust with $\varepsilon_{\mathrm{Nd}}$ values of 3.7 to +4.4 (Arndt, Todt, Chauvel, Tapfer, \& Weber, 1991). Neighbouring Coats Land (CL, Figure 30) contains $\mathrm{ca} 1100$ Ma magmatic ages similar to those in the Maud Belt, but lacks evidence of the 1000-1100 Ma metamorphic event and its origin is controversial (Boger, 2011).

The Maud Belt is a plausible exposed Antarctic source region for many of the juvenile late Grenvillian zircons in the Lachlan Orogen, although it cannot account for the youngest 950-1020 Ma grains.

It might seem that none of these three belts can provide the 490-620 Ma zircon population in the turbidites, unless they were locally reworked by Panafrican magmatism and metamorphism as described next. Areas marked as P1 and P2 are two broad belts of Panafrican magmatism or metamorphism, commonly but not exclusively reworking Grenville rocks equivalent to G1, G2 or G3. P1 is divided into P1a outcrops in the Denman Glacier region, while P1b outcrops occur in the Prydz Bay region (DG and PB, respectively, Figure 30). These two areas are regarded as southern extensions of the Pinjarra Orogen of Western Australia, where the southern Leeuwin Complex (south of PJ, Figure 30) contains both Grenvillian and Panafrican events (e.g. Harley et al., 2013). P1a outcrops around Denman Glacier contain 500-515 Ma charnockite and syenite plutons, with poorly studied gneissic basement that has yielded $c a 1.0$ and 3.0 Ga protolith ages. Basement and Panafrican plutons mostly have Nd model ages of 1.6-2.3 Ga (Fitzsimons, 2003). Farther west, in the P1b region, 495-550 Ma felsic magmatic and high-grade metamorphic rocks have reworked ca 1020-1400 Ma mafic and felsic protoliths (Rayner Complex) in Prydz Bay and the Grove Mountains (Liu, Todt, Chauvel, Tapfer, \& Weber, 2013), and a mixture of Archean (Ruker Complex) and Paleoproterozoic (Lambert Complex) protoliths, with local Grenvillian reworking (900-990 Ma Rayner Event), in the southern Prince Charles Mountains (Mikhalsky, Henjes-Kunst, Belyatsky, Roland, \& Sergeev, 2010). Panafrican granitoids in the southern Prince Charles Mountains have $\varepsilon_{\mathrm{Nd}}(\mathrm{t})$ values of -28 to -10 to (mostly -23 to -18 ), consistent with reworking of local 2800-3400 Ma basement rocks (model ages mostly 2.4-3.6 Ga; Mikhalsky et al., 2010), while those in the Grove Mountains have zircon $\varepsilon_{\mathrm{Hf}}$ values (estimated from Nd data) of -13.4 to -9.2 and model ages of 1.6 to 2.1 Ga (Liu et al., 2006), consistent with reworking of the Grenvillian Beaver Terrane and related rocks of the Rayner Complex.

Although the Panafrican P1 belt is a potential source of both Grenvillian and Panafrican detrital zircons, available $\mathrm{Nd}$ isotopic data suggest that exposed crust is too old to generate the more juvenile Panafrican and Grenvillian host magmas of the zircons in Ordovician turbidites of the Lachlan Orogen. The lack of Panafrican magmatic rocks older than $550 \mathrm{Ma}$ and an apparent absence of Panafrican mafic igneous rocks also argue against outcropping representatives of this belt being the sole source of detritus for the Lachlan turbidites. 
The second Panafrican belt (P2) lies between the Rayner Complex and the Maud Belt in Dronning Maud Land, and is exposed in Lützow-Holm Bay, the Sør Rondane Mountains, and outcrops in Central and Western Dronning Maud Land (LH, SR, CD, WD, respectively, Figure 30). These rocks are part of the East African Antarctic Orogen (Jacobs, Fanning, Henjes-Kunst, Olesch, \& Paech, 1998), a major belt of Panafrican continental collision and metamorphism exposed in eastern Africa, Madagascar, southern India, Sri Lanka and Antarctica. Panafrican events in Dronning Maud Land comprise 485-650 Ma high-grade metamorphism and deformation, associated with felsic and subordinate mafic magmatism, including large volumes of 485-520 Ma A-type late-tectonic granitoids (Table 4). Older basement rocks within this belt have dominantly Grenvillian protolith ages that vary consistently across the belt (Jacobs et al., 2015). The 1060-1150 Ma volcanic and granitoid protoliths in Western and Central Dronning Maud Land are interpreted as reworked Maud Belt rocks and have $\varepsilon_{N d}(t)$ values of -1 to +7 , which are similar to those further west where the Maud Belt has no record of a Panafrican overprint. Conversely, the 920-1015 Ma mafic to felsic protoliths with 1000-1070 Ma zircon xenocrysts in the Sør Rondane Mountains and adjacent nunataks have igneous ages equivalent to younger magmatic rocks in the Rayner Complex, but with more juvenile $\varepsilon_{\mathrm{Nd}}(\mathrm{t})$ values of -2 to +5 (Elburg et al., 2015; Jacobs et al., 2015). Jacobs et al. (2015) cited widespread 500-620 Ma magmatism in the central Dronning Maud Land and Elburg et al. (2015) cited 620 Ma granite and widespread 510-570 Ma granitoids in the Sør Rondane Mountains (Table 4). The boundary between these two protolith domains is interpreted as a major Panafrican suture (Jacobs et al., 2015), and it also marks a change in the isotopic character of Panafrican plutons. Panafrican granitoids in the Sør Rondane Mountains have $\varepsilon_{N d}(t)$ values of -5 to +2 , consistent with reworking of local juvenile Rayner crust, but they are more variable in Central and Western Dronning Maud Land with $\varepsilon_{N d}(t)$ values of -19 to -1 . The more negative values in this range are equivalent to model ages of 1.7-2.0 Ga and suggest the presence of Paleoproterozoic crust at depth below parts of the Maud Belt (Jacobs et al., 2015; Moyes, Groenewald, \& Brown, 1993).

Dronning Maud Land (P2) is a better match as a source for Lachlan Ordovician turbidites, and is consistent in part with the suggestions of Williams et al. (2002) and Squire et al. (2006c) that the sources of the Ordovician turbidites lay in the East African-Antarctic Orogen. Sources in Dronning Maud Land can provide both the 950-1120 and 490-620 Ma zircon populations that dominate the Lachlan turbidites, with few exposed rocks of other ages to dilute these ages. Older 1100-1400 Ma detrital zircons are relatively minor components in Dronning Maud Land and also in the Ordovician turbidites ( $\leq 10-15 \%)$. Late Grenvillian and late Panafrican mafic and felsic rocks in Dronning Maud Land also extend to suitably juvenile isotopic compositions, even though some model ages in Sør Rondane are too young. Importantly, this is also likely to have been a region of high elevation following the latest Neoproterozoic-Cambrian orogenesis and, even though it is exposed over a relatively small region, it is likely to extend under the Antarctic ice sheet for some distance towards Australia, increasing the volume of potential source rocks and decreasing the required sedimentary transport distance.

Inferred sub-ice terrains of the East Antarctica interior

Limited outcrop data together with detrital zircons from offshore and coastal regions imply that much of subglacial East Antarctica contains old Archean to Mesoproterozoic cratons, Grenvillian belts that show signs of reworking in the Panafrican, and Panafrican belts that contains relics of Grenvillian tectonics (Harley et al., 2013). Several such unexposed terranes may have provided zircons that match those in the Lachlan turbidites. 
Exposed Terre Adelie exposed basement is $\geq 1690$ Ma (TA, Figure 30). However, offshore sediments contain Grenvillian and Panafrican zircons that match those in the Lachlan Ordovician turbidites, as well major zircon populations $>1400 \mathrm{Ma}$, which are not seen in the turbidites (Veevers and Saeed, 2011) (Table 4; Figures 31 and 32). It is also possible that Grenvillian and Panafrican zircons in these offshore sediments were eroded from the Ross Orogen rather than Terre Adelie and so we exclude this region as a source.

Permian-Triassic sedimentary rocks in the Prince Charles Mountains and offshore in Prydz Bay contain major Panafrican and late Grenvillian zircons, presumably eroded from reworked Rayner Province or equivalent rocks (Veevers and Saeed, 2008) (Table 4). However, many samples contain significant pre-Grenvillian populations, suggesting this sector of the Antarctic interior is an unlikely source for Lachlan turbidites.

Offshore sediments eroded from Dronning Maud Land are also dominated by Panafrican and late Grenvillian zircons. The absence of significant pre-Grenvillian populations and the almost exclusively positive $\varepsilon_{\mathrm{Hf}}$ values of the late Grenvillian grains (Veevers and Saeed, 2013) make them a close match for the Lachlan turbidites. This distinctive subglacial zircon source was inferred by Veevers and Saeed (2013) to extend $1000 \mathrm{~km}$ inland from the Dronning Maud Land outcrops (VS, Figure 30), which is supported by aeromagnetic anomalies suggesting that the juvenile late Grenvillian outcrops in the Sør Rondane Mountains might extend inland across an area of at least 500 by $500 \mathrm{~km}$ (Jacobs et al., 2015) (TOAST, Figure 30). It is unlikely that this potential source region extends as far east as the Gamburtsev Subglacial Mountains (GSM, Figure 30), where detrital data point to a source with abundant pre-Grenvillian zircons (Veevers and Saeed, 2008), but its southern extent is unknown.

Based on detrital zircons in Permian strata, Elliott, Fanning, \& Hulett, (2015) proposed a possible 990-1080 Ma Grenvillian belt encompassing the Gamburtsev and Vostok Subglacial Mountains, with a possible 1100-1400 Ma belt (reworked in the Panafrican) between it and the western part of the Transantarctic Mountains. In the Miller Range, on the western side of the Transantarctic Mountains (MR, Figure 30), felsic orthogneiss glacial clasts with 1065-1100 Ma igneous protoliths (as well as ages $\geq 1400 \mathrm{Ma}$ ) and a 500-550 Ma metamorphic overprint led Goodge, Fanning, Brecke, Licht, \& Palmer (2010) to infer a Grenvillian source terrain with Panafrican overprint inland of the Central Transantarctic Mountains. The presence of preGrenville populations of similar abundance to late Grenville zircons makes a direct link to the Lachlan Ordovician turbidites unlikely.

\section{Ross Orogen}

The Ross Orogen of Eastern Antarctica (Figure 30) is exposed in the Transantarctic Mountains and extends along the paleo-Pacific margin of Antarctica between Australia and South America in Gondwana reconstructions. It is generally divided into six segments: northern Victoria Land (NV), itself comprising three or more terranes, southern Victoria Land (SV), the Central Transantarctic Mountains (CT), the Queen Maud Mountains (QM), the Thiel Mountains (TM) and the Pensacola Mountains (PS, all in Figure 30).

The development of a stratigraphy of metasedimentary units in the Transantarctic Mountains has had a checkered history, due to a scarcity of biostratigraphic constraints and the resultant difficulties in tracing units across major faults. The application of modern isotopic techniques to date detrital minerals and intrusive and extrusive units has produced new ideas and new correlations. As a result, we suggest we can recognise four main sequences (Figure 33). 
Sequence 1 (not discussed any further) is Archean and Paleoproterozoic basement of the Nimrod Group, a complex mixture of igneous and metasedimentary units intensely deformed by early orogenesis and only locally exposed in the Miller and Geologists ranges of the Central Transantarctic Mountains (Goodge, Myrow, Williams, \& Bowring, 2002) (MR, Figure 30). It forms part of the Mawson Craton (Boger, 2011). Sequence 2 is the mid-late Neoproterozoic passive margin sequence (sedimentary rocks + minor rift volcanics) that predates convergence in the Ross Orogen. Sequences 3 and 4 are latest Neoproterozoic to mainly Cambrian to earliest Ordovician sedimentary sequences deposited during the convergent margin phase of the Ross Orogen. The boundary between them is best represented by the structural boundary at the top of the Shackleton Limestone in the Byrd Group of the Central Transantarctic Mountains (Myrow, Pope, Goodge, Fischer \& Palmer, 2002). We use the different populations of detrital zircons above and below this boundary, specifically the incoming of $c a$ 470-600 Ma zircons in sequence 4 , as described in the literature, to extend this boundary into northern Victoria Land, Queen Maud and Pensacola mountains.

Sequences 2-4 are relevant to the Ordovician turbidites of the Lachlan Orogen. Brief descriptions of these units and their approximate detrital zircon age patterns follow. This text is tied into Figure 33 and is based on the greater detail presented in the Supplementary Papers (Appendix 5 and Table A6).

Sedimentary and rift-related volcanic rocks of Neoproterozoic Sequence 2 (Pre-convergent margin stage).

Neoproterozoic sequence 2 is best represented by the Beardmore Group in the Central Transantarctic Mountains, divided into a lower (ca ?675-690 Ma) Cobham Formation and an upper (ca ?550-675 Ma) Goldie Formation, which contains 668 Ma gabbros (Goodge et al., 2004b) (Figure 33). Both formations contain a dominant 1400-1900 Ma zircon population, with a lesser 1100-1300 Ma population, and fewer and variable numbers of grains between 2500$3000 \mathrm{Ma}$ (Goodge et al., 2004b). In southern Victoria Land, the age of the equivalent Skelton Group is poorly constrained but may extend from $675 \mathrm{Ma}$, with deformation and metamorphism of the sequence inferred to have begun at ca 615 Ma (Hagen-Peter, Cottle, Smit, \& Cooper, 2016). As in the Beardmore Group, detrital zircon ages in the Skelton Group define a ca 900-1300 Ma population and a ca 1500-2000 Ma population, but the dominance is reversed: 900-1330 Ma zircons are more numerous than 1500-2000 Ma zircons (Cooper, Maas, Scott, \& Barber, 2011; Stump, Gehrels, Talarico, \& Carosi, 2007). The Skelton Group also contains a small number of grains from ca 2000-2500 Ma (Figure 33). A ca 630-900 Ma population is present in some samples (Cooper et al., 2011; Stump et al., 2007), but not in the Dry Valley samples of Wysoczanski and Allibone (2004) and may reflect 'localised' rift volcanism. In the Wilson Terrane of northern Victoria Land, the ca 562-592 Ma lower Priestley Formation of Estrada et al. (2015) may also be part of sequence 2, based on their inferred lower and upper ages 562 and $592 \mathrm{Ma}$ (Figure 33). However, the detrital zircon pattern (dominant 550-700 Ma population, in addition to the less dominant 950-1300 Ma population, and grains between 1650-2100 and 2200-2800 Ma, Figure 33) is more akin to that of the younger sequence 3, thus querying its inferred age.

Rift-related igneous rocks of sequence 2 in the Transantarctic Mountains are relatively rare and have been linked to Neoproterozoic rifting along the Gondwana-proto-Pacific margin (Table 5). These igneous rocks include: The Cotton Plateau Gabbro dated at 667.8 \pm 0.6 Ma (Goodge et al., 2002); pillow basalts in the Skelton Group of southern Victoria Land with Sm-Nd (mantle 
separation) ages of 680-780 Ma (Rowell et al., 1993); and rhyolite clasts in rift-related and MORB-like mafic and felsic volcanics, also in the Skelton Group, with zircon ages of $650.1 \pm 4.8$ and 648.5 $\pm 3.2 \mathrm{Ma}$ (Cooper et al., 2011). An earlier stage in this rifting event might be preserved by picrites in the Shackleton Range with 770-870 Ma mantle-separation ages (Schmaedicke, Will, \& Mezger, 2015) that are inferred to have formed during Rodinia breakup (Table 5).

These ages suggest that mafic-derived detrital zircons in the Lachlan turbidites with ages of 800-900 Ma (in Bun4, Bun8 and Ben5) and 600-700 Ma may be rift-related, whereas those with ages $<535 \mathrm{Ma}$ (see above) relate to arc volcanism.

Sedimentary rocks of Sequence 3 (convergent margin stage)

Sedimentary sequence 3 is mainly Cambrian, although beginning at ca 545-550 Ma in the Neoproterozoic (Ediacaran). It extends along the Ross Orogen from northern Victoria Land to the Pensacola Mountains, although relationships with older units are generally not clear and ages are generally ill-defined. A characteristic of sequence 3 is the general presence of a new dominant detrital zircon population of $c a$ 540/550-700 Ma. In the Wilson Terrane of northern Victoria Land, these sequence 3 units also contain the older zircon populations of sequence 2, with 900-1200, 1550-2000, 2000-3400 Ma populations in the ?532-548 Ma upper Priestley Formation, but only 950-1300 and 2000-3400 Ma populations in the ?coeval Berg Group (Adams, Bradshaw, \& Ireland, 2014). In the Queen Maud and Pensacola mountains, sequence 3 is represented by the La Gorce Formation, deposited between ?537 and ?550 Ma (Curtis, Millar, Storey \& Fanning, 2004), the ?540-555 Ma Duncan Formation and the ?519-538 Ma Hannah Ridge Formation. All three units contain the dominant 550-650/700/755 Ma zircon population, the older 900-1200 Ma population, but no significant older grains. In the Central Transantarctic Mountains sequence 3 is represented by the Shackleton Limestone, dated between 513-521 Ma (Goodge et al., 2004b; Myrow et al., 2002; Peng, Babcock \& Cooper, 2012). In contrast to the Queen Maud Mountains and Pensacola Mountains, the basal sandstone in the Shackleton Limestone only contains the same detrital zircon patterns as found in the underlying sequence 2 and lacks the 540/550-700 Ma population.

\section{Koettlitz Glacier Alkaline Province in Southern Victoria Land}

Intrusions of the Koettlitz Glacier Alkaline Province in southern Victoria Land are thought to be transtension-related, emplaced into a failed continental rift (Read, 2010; Read, Cooper \& Walker, 2002). They have been dated between $c a$ 517-551 Ma, using both titanite and zircons (Read et al., 2002). Veevers et al. (2006) reported additional ages in the same range (plus one at $507 \mathrm{Ma}$ and a ?xenocryst at $567 \mathrm{Ma}$ ), and $\varepsilon_{\mathrm{Hf}}$ values from -4 to +10 . Read (2010) refined the emplacement ages, suggesting alkaline magmatism occurred at 542-557 Ma with younger ages reflecting resetting during subsequent deformation and cooling. Emplacement ages correlate in time with sequence 3 (Figure 33).

It is tempting to suggest that these rocks are potential sources for the late Panafrican alkaline volcanic-sourced zircons in the Lachlan Orogen turbidites, and Veevers et al. (2006) made this linkage. However, the turbidite 'alkaline' zircons commonly extend to more negative $\varepsilon_{\mathrm{Hf}}$ values (Table 5; Figure 32), and 26/39 'alkaline' late Panafrican age zircons in the Ordovician turbidites are $>557$ Ma older than the oldest age of Read (2010), although this would reduce when errors are taken into account. It thus appears that the Koettlitz Glacier Alkaline Province may not be a major contributor to alkaline zircons in the Lachlan Ordovician turbidites, especially since many 
of these zircons occur in sandstones of the Bendigo Terrane that may not be sourced from the Ross Orogen (see below).

The Granite Harbour Intrusives

The Ross Orogen convergent margin is represented by its granitic roots - lower Cambrian foliated to Lower Ordovician massive granites termed the Granite Harbour Intrusives that outcrop along the Transantarctic Mountains. These were generated by the subduction melting of mantle components mixed with different amounts of continental crust (e.g. Borg et al., 1987; Cox, Parkinson, Allibone \& Cooper, 2000).

The Granite Harbour Intrusives were emplaced mainly between $c a$ 480-510 Ma in northern Victoria Land (Rocchi, Bracciali, Di Vincenzo, Gemelli \& Ghezzo, 2011); ca 499-505 Ma in the Dry Valleys area of southern Victoria Land, according to Cox et al. (2000), but ca 492-515 Ma according to Hagen-Peter, Cottle, Tulloch \& Cox (2015); ca 490-545 Ma in the Central Transantarctic Mountains, with the oldest ages lying inboard in the Miller Range (Goodge, Fanning, Norman \& Bennett, 2012); and ca 485-535 Ma in the Queen Maud Mountains (Paulsen et al., 2013; summarised in Figures 30 and 31). Syntectonic granitoids (with a gneissic foliation) are older than ca $495 \mathrm{Ma}$ in northern Victoria Land (Rocchi et al., 2011), ca 520-545 Ma in the central Transantarctic Mountains (e.g. Goodge et al., 2012) and ca 505-535 Ma in the Queen Maud Mountains (Paulsen et al., 2013) (Table 5). The oldest granitoids in northern Victoria Land appear to be $521 \mathrm{Ma}$ (Bomparola and Ghezzo 2007) and 544 Ma (Black and Sheraton 1990), with mafic intrusives in part of the mafic Tiger Arc of Northern Victoria Land, having a Sm-Nd age of $535 \pm 21$ Ma (Bracciali, Di Vincenzo, Rocchi \& Ghezzo, 2009; Rocchi et al., 2011). In southern Victoria Land, the oldest convergent margin intrusion is a gabbro dated at $546 \mathrm{Ma}$ (Cottle and Cooper, 2006), with one suite dated at 516-531 Ma (Cox et al., 2000). The older intrusions imply that convergent margin tectonism began in the Ross Orogen by ca $550 \mathrm{Ma}$, although Goodge et al. (2012) used core and rim zircon data from glacial clasts to argue that the arc began by ca $590 \mathrm{Ma}$. Most of the Granite Harbour Intrusives granitoids are metaluminous (biotite-hornblende-rich) and calcalkaline, although some peraluminous ones in Northern Victoria Land have $\mathrm{Rb}-\mathrm{Sr}$ whole rock isochron ages of $484 \pm 17$ and $481 \pm 10 \mathrm{Ma}$ (Bomparola and Ghezzo, 2007). Cox et al. (2000) suggested that some of the igneous suites from southern Victoria Land had been generated by the subduction melting of mantle components mixed with different amounts of continental crust.

The ranges of intrusion ages match the Panafrican zircons in the Lachlan Ordovician turbidites, especially the younger ones, but can they provide the late Grenvillian populations? In northern Victoria Land, the 544 Ma diatexite dated by Black and Sheraton (1990) contains 1130 Ma and older zircon xenocrysts. Xenocrysts in Granite Harbour Intrusives dated by Bomparola and Ghezzo (2007) have major populations at 530-540, 600 and $700 \mathrm{Ma}$, but no Grenvillian peaks. Granites described by Cox et al. (2000) and Hagen-Peter et al. (2015) from southern Victoria Land did not contain any. The only Grenvillian xenocrysts described from the Central Transantarctic Mountains by Goodge et al. (2012) were restricted to one glacial clast in the Miller Range. Orthogneiss and diorite in the Central Transantarctic Mountains just north of the Shackleton Glacier have crystallisation ages of $504 \mathrm{Ma}$, with no inheritance (Paulsen et al., 2013). However, just south of the Shackleton Glacier in the Queen Maud Mountains (QM, Figure 30), Ross-age orthogneisses and undeformed granites (mainly biotite rich with only a few two-mica plutons; Stump, 1995) and with major zircon crystallisation ages of 503 and 532 Ma contain distinctive xenocrystic Grenvillian zircons, with age peaks at 958, 1020 and 1060 Ma (Paulsen et 
al., 2013). These xenocrystic granites extend into the Thiel Mountains and Pensacola Mountains (TM and PS, respectively, Figure 30), where Paulsen et al. (2013) cited $1093 \pm 23$ and $981 \pm 31$ Ma intercept discordia ages of Van Schmus, McKenna, Gonzales, Fetter \& Rowell (1997). Late Grenvillian ages could also extend to the Shackleton Range (SR, Figure 30), where Will, Zeh, Gerdes, Frimmel \& Millar (2009) recorded a ca 1060 Ma (late Grenvillian) granitoid overprinted by $c a 600$ Ma metamorphism.

Based on the data discussed above, up to $50 \%$ of the granite roots of the Ross Orogen continental-margin arc might thus contain both late Grenvillian and late Panafrican zircons that match the two main detrital zircon populations in Lachlan Ordovician turbidites - but these all occur in that part of the orogen farthest from Australia, between the Queen Maud and Pensacola mountains (referred to here as the southern Ross Orogen). The northern edge of these xenocrystic granites (shown by the limit to dots in Figure 30) lies approximately at the boundary between the Queen Maud Mountains to the south and the Central Transantarctic Mountains to the north, and coincides with the Shackleton Glacier, which also marks a change in the Nd model ages of Granite Harbour Intrusives from 1.1-1.5 Ga in the south to 1.6-1.9 Ga in the north (Borg and DePaolo, 1994). This change in granite geochemistry presumably reflects the age of underlying basement, and the combination of 1.1-1.5 Ga model ages and 950-1100 Ma zircon xenocrysts is consistent with juvenile Mesoproterozoic, late Grenvillian basement underlying the southern Ross Orogen (supported by Nd model ages of 0.7-1.5 Ga for 525-500 Ma rhyolitic units in the Queen Maud Mountains; Wareham, Stump, Storey, Millar \& Riley, 2001). In contrast, Paleoproterozoic basement is inferred to extend under the orogen northwards from the Shackleton Glacier to northern Victoria Land, with even older crust on the inland side of the Central Transantarctic Mountains (2.0-3.2 Ga model ages in Granite Harbour Intrusives of the Miller Range area; Borg and DePaolo, 1994; Goodge et al., 2012). Neoproterozoic crust also occurs beneath the outboard Bowers and Robertson Bay terranes in northern Victoria Land, where intrusive granitoids have 1.1-1.5 Ga model ages (Borg and DePaolo, 1994).

Variations in the ages and juvenile or evolved character of underlying basement are supported by preliminary results from a regional Hf isotopic study of Ross-age granites: Fanning, Goodge and Vervoort (2015) reported a total +7 to -16 range of zircon $\varepsilon_{\mathrm{Hf}}$ values and described a major discontinuity close to the Shackleton Glacier between Mesoproterozoic crust to the south and Archean-Proterozoic crust to the north (plotted in line 2 in row called Granite Harbour Intrusives central Transantarctic Mountains; Figure 32). Fanning et al. (2015) also reported zircon xenocryst ages of $c a 1200,1600,2000$ and 2500 Ma from these granites, although they did not describe their spatial distribution. They also did not report separate $\varepsilon_{\mathrm{Hf}}$ ranges for either side of the Shackleton Glacier discontinuity, precluding any direct comparisons with the Lachlan turbidites. However, limited xenocryst and whole-rock Nd data suggest that Granite Harbour Intrusives of the southern Ross Orogen and their inferred Mesoproterozoic basement could have supplied the dominant Panafrican and late Grenvillian detrital zircon populations.

Another way of ascertaining whether the Granite Harbour Intrusives are possible sources of zircons in the Lachlan Ordovician turbidites is by comparing available $\varepsilon_{\mathrm{Nd}}$ data (restricted in the literature to northern Victoria Land, southern Victoria Land and Central Transantarctic Mountains) with the $6 \varepsilon_{\mathrm{Nd}}$ values ( -10.5 to -8.3$)$ from the Lachlan 'Ordovician turbidites' referred to above. Comparison with data in Table 5 show these do overlap best with peraluminous granitoids from northern Victoria Land (Rocchi et al., 2011) and the postkinematic basement granites of the Central Transantarctic Mountains (Goodge et al., 2012). In the light of the very limited Lachlan Ordovician turbidite $\varepsilon_{\mathrm{Nd}}$ data, we compared our zircon $\varepsilon_{\mathrm{Hf}}$ 
data with $\varepsilon_{\mathrm{Hf}}$ data calculated from the $\varepsilon_{\mathrm{Nd}}$ data of the Granite Harbour Intrusives in Table 5 (with potential problems as stated above). We show this in upper rows of Figure 32, where the numbers are linked into lithotypes in Table 5. Our calculated $\varepsilon_{\mathrm{Hf}}$ values from $\mathrm{ca}$ 493-507 Ma post-kinematic outboard granites of Goodge et al. (2012) in the Central Transantarctic Mountains overlap with the very negative $\varepsilon_{\mathrm{Hf}}$ values of late Panafrican zircons in the Albury-Bega Terrane east and in the Hermidale Terrane, but most of these Panafrican detrital zircons are $>520 \mathrm{Ma}$ old. Only the more juvenile calculated $\varepsilon_{\mathrm{Hf}}$ values for syn-late kinematic basement intrusive rocks of Goodge et al. (2012; plotted in line 4 in the Central Transantarctic Mountains row in Figure 32) overlap with Ordovician turbidite zircon data. The calculated $\varepsilon_{\mathrm{Hf}}$ values of granites from unspecified settings in Goodge et al. (2012), -26.9 to -1.8 (line 1, Figure 32), show some overlap with zircons from Ordovician Lachlan Ordovician turbidites, as do some of the granitoids of Borg, DePaolo and Smith (1990) from the Central Transantarctic Mountains (line $7 b$, Figure $32 ; \varepsilon_{\mathrm{Hf}}-11.8$ to -4.9 ). In the Dry Valleys of southern Victoria Land, the adakitic suite calculated $\varepsilon_{\mathrm{Hf}}$ range of -12.6 to -2.9 to (line 3 in Figure 32) overlaps with most late Panafrican zircons in the Lachlan Ordovician turbidites, more so than the other granitoids in the area. In northern Victoria Land, a range in $\varepsilon_{\mathrm{Hf}}$ of -26.9 to -1.8 calculated from the $\mathrm{Nd}$ data of Rocchi, Tonarini, Armienti, Innocenti and Manetti (1998; plotted in line 1 Figure 32, northern Victoria Land granitoid Granite Harbour Intrusives row) is generally more negative than most detrital zircons in the Lachlan Ordovician turbidites.

Granite Harbour intrusives in the Queen Maud Mountains and PD3

The Grenvillian juvenile basement that underlies the southern Ross Orogen is marked with dots in Figure 30. Its affinity is unknown, and one possibility is that it may represent the southern extension of the Pinjarra Orogen. The location of this southern extension is conjectural, and at least three different pathways have been inferred under the ice, with ongoing debate about the relative roles of Grenvillian and Panafrican events in its evolution (e.g. Boger, 2011; Fitzsimons, 2003; Harley et al., 2013). One potential pathway labelled PD3 (for Prydz-Denman Orogen in Figure 30; Harley et al., 2013) is inferred to pass between the Queen Maud Mountains near the South Pole and Prydz Bay and Denman Glacier on the Indian Ocean coast of Antarctica. PD3 could only act as a source region for the Lachlan Ordovician turbidites if the concealed parts contain more juvenile Grenvillian zircons than these last two areas (Supplementary Papers, Appendix 1), but this matches the limited data on basement under the southern Ross Orogen. PD3 could also be the late Grenvillian and Panafrican source terrane of the glacial clasts and sandstone detritus between the central Transantarctic Mountains and the Gamburtsev Subglacial Mountains (Elliot et al., 2015; Goodge et al., 2010) (CT and GSM, repectively, Figure 30). However, there are other possibilities for this basement such as extensions of Dronning Maud Land, discussed above.

Convergent margin volcanic rocks of Sequence 4

Most of the volcanic upper parts of Ross Orogen convergent margin (lying in sequence 4) appear to have been removed by erosion. Remnants mainly occur in the Liv Group in the Queen Maud Mountains (Stump, 1995), for which Wareham et al. (2001) suggested a rift-basin setting behind a subducting margin with volcanism from $c a 500$ to $530 \mathrm{Ma}$. The oldest volcanics include the 526 \pm 2 Ma Wyatt Formation (dacitic pyroclastic ?ignimbrites) and $524 \pm 2$ Ma Ackerman Formation (interbedded sediments with volcanics and some lavas; Encarnacion and Grunow, 1996). Younger units in the Liv Group include the 514-517 Ma Leverett Formation, the 489-520 or ca 550 Ma Fairweather Formation (Van Schmus et al., 1997) and the ca 501 Ma Taylor Formation 
(Wareham et al., 2001) (Table 4). Tuff associated with basalt in the Shackleton Limestone (lower Byrd Group) in the Central Transantarctic Mountains has a U-Pb zircon age of $511 \pm 3 \mathrm{Ma}$ (Stump et al., 2004). The youngest arc-related volcanics are the $501 \pm 3$ and $500 \pm 5$ Ma felsic Gambacorta Volcanics in the Pensacola Mountains (Millar and Storey, 1995) and the $505 \pm 1 \mathrm{Ma}$ rhyolite porphyries of the Taylor Formation in the Liv Group of the Queen Maud Mountains (Encarnacion, Rowell \& Grunow, 1999). Mafic igneous rocks include a ca 546 Ma gabbro from southern Victoria Land (Cottle and Cooper, 2006) (Table 5) and gabbro at Gabbro Hills in the Queen Maud Mountains (Borg and DePaolo, 1991).

Convergent margin sedimentary rocks of Sequence 4

Cambro-Ordovician sedimentary sequence 4 is developed along the length of the Ross Orogen, recognised by units < ca $513 \mathrm{Ma}$, except in the Queen Maud Mountains where it is $<$ ca $525 \mathrm{Ma}$ (Figure 33). The distinguishing feature in most samples of sequence 4 is the presence of grains <ca 540/560 Ma, and extending to at least $480 \mathrm{Ma}$, and maybe even ca $465 \mathrm{Ma}$ in the Robertson Bay Group. In northern Victoria Land, sequence 4 is represented by the ca 483-494 Ma Molar Formation in the Bowers Terrane and the $c a$ 464-483 Ma Robertson Bay Group in the Robertson Bay Terrane. Both units also contain the older $c a$ 900-1200 and $c a$ 1400-1700 Ma populations, with the $>2000$ Ma population found only in the Molar Formation. In the Central Transantarctic Mountains, sequence 4 is represented by the upper Byrd Group, with a base at $513 \mathrm{Ma}$ and an uncertain upper age limit of $c a 470 \mathrm{Ma}$, defined by the youngest grains in the dominant $c a 470-$ 600 Ma population. The upper Byrd Group also contains all older detrital populations from the underlying sequences in the Central Transantarctic Mountains. In the Queen Maud Mountains, sequence 4 is represented by the Liv Group, with upper and lower boundaries defined by 503 and 526 Ma volcanics, respectively (e.g. Wareham et al., 2001). The dominant population is 480$650 \mathrm{Ma}$, with lesser populations of older grains (Paulsen et al., 2015) that are similar to those in the underlying sequence 3. In the Pensacola Mountains sequence 4 is represented by the Patuxent Formation, which contains 500 Ma volcanics (Rowell, Van Schmus, Storey, Fetter \& Evans, 2001). Detrital zircon grains in the Patuxent Formation define a dominant 500-620 Ma population with lesser numbers of 900-1200 Ma grains, like in underlying sequence 3.

Zircon probability plots of the upper Byrd and Liv groups plotted from the data of Goodge et al. $(2002,2004 b)$ and Paulsen et al. (2015) show most samples have major changes in populations around 540-560 Ma. In the upper Byrd Group, 3 samples have major peaks < $540 \mathrm{Ma}$, sample HRS has a peak at $c a 540 \mathrm{Ma}$, two have peaks above and below $540 \mathrm{Ma}$, while sample 98206A has a $c a 540 \mathrm{Ma}$ saddle between a major peak $>540 \mathrm{Ma}$ and a smaller peak $<540 \mathrm{Ma}$ (Figure 33a). In the Liv Group, 3 samples have major peaks $<540 \mathrm{Ma}$, two have major peaks at $540 \mathrm{Ma}$ (LUB2B, HEN2), RAM1 has a small peak only < 560 Ma while RAM2 has a double peak at ca 550 and $565 \mathrm{Ma}$ (Figure 33b).

The history of these Ross Orogen sequences recorded by the detrital zircon patterns in sedimentary rocks (Figure 33) shows: i) inheritance of older detrital populations upwards from sequence 2 in the Central Transantarctic Mountains (but sequence 3 elsewhere) into sequence 4, implying either recycling of older sedimentary units or the persistence of original primary sources through time; ii) the appearance of new and younger sources supplying a flood of $<540$ $560 \mathrm{Ma}$ zircons into sequence 4 depocentres along the orogen that were still receiving the older zircons from underlying sequences or their primary sources; and iii) orogen-parallel segmentation of depocentres, at least during sequence 2 and 3 times, principally between northern Victoria Land and Central Transantarctic Mountains on one hand, and the Queen Maud 
Mountains and Pensacola Mountains on the other. The flood of $<540-560$ Ma zircons in the Cambro-Ordovician sequence 4 in both regions suggests the overwhelming of old basin margins. Rather than a change from rift to sag-type deposition, Goodge et al. (2004b) suggested that the $<540 / 550$ Ma zircons probably marked the onset of syntectonic sedimentation.

Which of these sequences are relevant to the sources of the Lachlan Ordovician turbidites? The above descriptions show that sequence 4 in the Ross Orogen is a potential, but obviously not primary, source. Older sequences have potential only if there were additional sources of the $<540-560$ Ma zircons.

We further investigate this possible link between Lachlan Ordovician turbidites and sequence 4 of the Ross Orogen by looking at the upper Byrd and Liv groups, which have the most available zircon data. The closeness of this match is supported by the similar mineralogies. Sandstones in the upper Byrd Group range from massive quartz-rich to feldspathic greywackes, containing quartz, plagioclase, K-feldspar, muscovite, biotite, Fe-Ti oxides, tourmaline, sphene, and calcite, and lithic fragments that may include polycrystalline quartz, slate, schist, sandstone, quartzite, limestone, granite and/or calcite (Goodge et al., 2004a). These compare well with the modal compositions of the Lachlan turbidites (Figure 2a). The closeness of this match is also supported by overlapping ages of detrital muscovite grains from parts of the Lachlan Orogen and from the upper Byrd Group (inferred to have a metamorphic origin, Goodge et al., 2004b), and from the Liv Group, with inferred igneous or igneous and/or metamorphic origins (Figure 25; Paulsen et al., 2015).

This close match is also shown in Figure 34, which compares zircon probability plots for the upper Byrd Group (Goodge et al., 2002, 2004b) and the Liv Group (Paulsen et al., 2015) with samples of Ordovician turbidites from different terranes and ages in the Lachlan Orogen. This match works in the 400-1600 Ma range (Figure 34a-c), but note that the small relative size of the Grenvillian peaks in the Liv Group plot (Figure 34b) is because of the very high probability of the single Panafrican peaks in three samples with a unimodal age distribution. Figure $34 \mathrm{~d}$ illustrates better the relative contributions from this population. The 400-3000 Ma range probability plot (Figure 34d, e) emphasises the similarity in numbers of zircon grains older than the late Grenvillian (950-1120 Ma). In addition to the matching late Panafrican and late Grenvillian populations, three of the Ordovician turbidites (Oggyc1, Mum1, Oww5) also possess ca 650-675 Ma detrital peaks that encompass the ages of rift volcanism in sequence 3 (the Skelton Group), and which are also present in some samples of sequence 4 (Figure 34).

The 400-700 Ma comparison plots of zircons between the upper Byrd and Liv groups in sequence 4 and the four plots of Lachlan Ordovician turbidites (two Lower Ordovician, two upper Middle Ordovician from the three eastern terranes) show similar peaks and saddles, even with our restricted data (Figure 34h-j). Figure 34j shows Mum1 and Oww5 have peaks either side of a saddle at $c a 560 \mathrm{Ma}$, Oggyc1 has major peaks either side of saddles at ca 530 and 510 $\mathrm{Ma}$, and Bun4 has major peaks either side of a double saddle at ca 510 and $545 \mathrm{Ma}$. The plot of all the Lachlan Ordovician turbidites (Figure 34) shows the persistent saddles, at ca $530 \mathrm{Ma}$ (Bun4, 527 Ma; Mum1, 529 Ma; Te2, 532 Ma; Bun9, 534 Ma; Tritton NE, 535 Ma; Oggyc1, 537 Ma; Mwb1, 542 Ma); at ca 560 Ma (Oww5, 561 Ma; Bun8, 563 Ma; Oww3, 563 Ma; Mum1, 564 Ma); and at ca 515 (Oww5, 515 Ma; Oww3, 515 Ma; Bun8, 517 Ma). Samples from the Bendigo Terrane are exceptions, as discussed previously, with their younger saddles (Ben2, $504 \mathrm{Ma}$; Ben 5, $504 \mathrm{Ma}$; Cob1, $506 \mathrm{Ma}$ ) and older saddles (Ben2 and Ben5, $569 \mathrm{Ma}$; Cob1, $600 \mathrm{Ma}$ ). 
Although the upper Byrd and Liv groups from sequence 4 from the Ross Orogen provide excellent matches for the $\mathrm{U}-\mathrm{Pb}$ ages of zircons in the Lachlan turbidites, a more conclusive correlation requires matching $\varepsilon_{\mathrm{Hf} /} \varepsilon_{\mathrm{Nd}}$ data. Available $\varepsilon_{\mathrm{Nd}}$ values for 8 samples of upper Byrd Group range from - 10.7 to -5.2 (Goodge et al., 2012) overlap with the six $\varepsilon_{\mathrm{Nd}}$ values from the Lachlan 'Ordovician turbidites' from -10.5 to -8.3 . Despite the obvious limitations, these overlapping values support the linkage between the upper Byrd Group and the Lachlan Ordovician turbidites. We also converted the upper Byrd Group $\varepsilon_{\mathrm{Nd}}$ to $\varepsilon_{\mathrm{Hf}}$ values of -19.0 to -9.8 , mainly -12.0 to -8.9 (Table 6; Figure 32). These are more negative than most of the Panafrican zircons in the Lachlan Ordovician turbidites (Figure 32), illustrating the problems in comparing $\varepsilon_{\mathrm{Hf}}$ and $\varepsilon_{\mathrm{Nd}}$ data.

\section{Possible Antarctica-Lachlan Ordovician turbidite connections}

The need for relatively juvenile crust (Mesoproterozoic model ages) and limited numbers of early- and pre-Grenvillian zircons means that the most likely ultimate, primary sources of Lachlan Ordovician turbidites resolve into: i) Central and Western Dronning Maud Land, the Sør Rondane Mountains, and their extensions inland; ii) parts of the Ross Orogen exposed in the Queen Maud, Thiel and Pensacola mountains, with an inferred Mesoproterozoic basement, and possible extension inland that may connect with iii), a possible subglacial Antarctic extension (PD3) of the Pinjarra Orogen passing to the east and south of the Gamburtsev Subglacial Mountains.

Let us begin with option i). Of all our samples, those from the Bendigo Terrane show the least amount of change over time in $\varepsilon_{\mathrm{Hf}}$ values and U-Pb ages of Panafrican zircons (Figures 11, 26 and 29). We infer a near-constant source for these rocks that contained fewer late Grenvillian 900-1100 Ma granites \pm mafic \pm alkaline rocks and more late Panafrican 485-600+ Ma granites \pm mafic \pm alkaline rocks, with both derived by repeated melting of 1.1-1.9 Ga crust. The constancy of these sources might imply an intraplate location by the late Panafrican. We thus tentatively suggest that these rocks, the most inboard Ordovician turbidites in the Lachlan Orogen, were derived directly from an East Antarctic source such as Dronning Maud Land, by repeated melting in late Grenvillian and late Panafrican times. If that were the case, we then envisage a direct distributary system from Dronning Maud Land into the Bendigo Terrane of the Tasmanides (Figure 30), from ca 460-485 Ma and filling a backarc sub-basin lying west of the Selwyn Block (SB, Figure 30) (Glen et al., 2016). Of course, and as shown in Figure 30, such a distributary system must have crossed the inferred path of PD3, with the probability of picking up zircons along the way, unless the intersections were in low covered areas with no outcrop. Indications that Panafrican movements along this belt included a significant component of strike-slip faulting (Fitzsimons, 2003) suggest it might not have formed a significant topographic barrier to sediment transport.

Let us now look at option ii) sources in or flanking the Ross Orogen. Our second, tentative conclusion concerns the chert-rich Lower Ordovician turbidites of the Hermidale and AlburyBega terranes in the Lachlan Orogen, filling the backarc sub-basin east of the Selwyn Block (Glen et al., 2016). Because zircons in these turbidites show much more variation in both ages and $\mathrm{Hf}$ values between terranes, and also upsection within a terrane than those in the Bendigo Terrane, we speculate that they were derived from sources adjacent to the evolving proto- to paleoPacific plate boundary in East Antarctica. 
It was shown above that there is an excellent match in $\mathrm{U}-\mathrm{Pb}$ detrital zircon ages and available $\mathrm{Nd}$ data between sequence 4 units in the Ross Orogen, especially the upper Byrd and Liv groups, and the Lachlan Ordovician turbidites. Potential sources of sequence 4 in the Ross Orogen can thus help identify the sources of the Ordovician turbidites. Using this example, we discuss this now in more detail than we could do for sources of the Bendigo Terrane.

What were the primary sources of the zircons $<$ ca 540-560 Ma in sequence 4 and, by extrapolation, in the eastern Lachlan Ordovician turbidites where they form distinctive groupings? Some of these zircons could have been sourced from Ross arc volcanics, now largely eroded. Goodge et al. (2004b) and Paulsen et al. (2015) both described euhedral igneous zircons from the upper Byrd Group, and the Liv Group also contains subduction-related volcanics at 526, $524,515,501 \mathrm{Ma}$, with samples of sedimentary rocks containing unimodal peaks. Other zircons in this population may have come from the Granite Harbour Intrusives, with the general consensus from Ar-Ar data that this source was not available at the surface until ca $515 \mathrm{Ma}$, based on cooling ages of muscovite, hornblende and biotite that were related to exhumation, uplift and the unroofing of the Ross Orogen (see below).

Other zircons $<540-550$ Ma were derived from metasedimentary sources. Metasedimentary input into sequence 4 (and thus, we suggest, by extension into the Lachlan Ordovician turbidites) is reflected by fragments of slate, mica schist and wacke, together with detrital muscovite grains (e.g. Goodge, Myrow, Phillips, Fanning \& Williams, 2004a; Paulsen et al., 2015). The muscovites were derived from metasedimentary rocks, since the "I-type" Granite Harbour Intrusives are overwhelmingly hornblende- and biotite-bearing, not muscovite-bearing (Goodge et al., 2004a). The 48/50 detrital muscovite grains in four samples of the upper Byrd Group are $<545 \mathrm{Ma}$ (Goodge et al., 2004a), although from an additional sample, Paulsen et al. (2015) recorded more complex, multiple age populations of muscovites (527-579>590-620>590-600 $\mathrm{Ma}$ ), derived from either metamorphic sources or metamorphic \pm igneous sources. $\varepsilon_{\mathrm{Nd}}$ data of sandstone in the upper Byrd Group show only moderate matches with granitoids from the Central Transantarctic Mountains (Goodge et al., 2012), supporting input from other sources or reflecting complex mixing. Whether this metamorphic sedimentary component was derived directly from external sources or indirectly, via secondary sources such sequences 2 and 3 in the Ross Orogen, is unknown.

A key question is whether the flood of zircons <ca 540-560 Ma reflects changing dynamics only within the Ross Orogen. Zircons as young as 485 and 500 Ma also occur in parts of belt PD3, Dronning Maud Land and Sør Rondane, and thus suggest that this zircon population reflects wider changes. Several workers have suggested that the East African Antarctic Orogen underwent a transition from Panafrican collision-generated deformation and melting at 560$580 \mathrm{Ma}$, to extensional exhumation and melt generation beginning around 530-540 Ma (e.g. de Wit et al., 2001; Fitzsimons, 2016; Jacobs, Fanning \& Bauer, 2003). Alternatively, the 515-530 Ma events have been interpreted as a later collision by several workers (e.g. Boger, 2011; Collins and Pisarevsky, 2005). It thus appears that these fundamental changes are also recorded in the zircons in and around the Ross Orogen and also in the Lachlan Ordovician turbidites, albeit beginning slightly earlier at $c a 560 \mathrm{Ma}$ in both regions.

What was the source of the $c a 550-700$ Ma population in sequences 3 and 4 in the Ross Orogen and the $c a$ 550-620 Ma part of the late Panafrican population in the eastern Lachlan Ordovician turbidites? In the Ross Orogen, zircons of this age were recycled through sequences 3 and 4 and predate the onset of Ross Orogen subduction-related magmatism, although Goodge et al. (2012) 
suggested that 589 Ma zircon cores in glacial granites in the Miler Range area marked the onset of arc activity. If they predated Ross magmatism, they must have been derived from inland sources, external to the Ross Orogen. Central and western Dronning Maud Land, Sør Rondane or an extension of the Pinjarra Orogen, such as belt PD3, all contain zircons of the appropriate ages, as well as being able to supply the late Grenvillian population.

What is the source of the late Grenvillian 950-1120 Ma population? Zircons of this age are present in all three Ross sequences (excluding the Beardmore Group; Figure 33) and suggest derivation from external sources, with central and western Dronning Maud Land, Sør Rondane or an extension of the Pinjarra Orogen such as belt PD3, the most likely source regions with best age matches. What about Ross Orogen primary sources? Granite Harbour Intrusives in the Central Transantarctic Mountains, southern Victoria Land and northern Victoria Land lack Grenvillian xenocrystic zircons, so these outcropping granitoids did not supply any zircons of this age to sequence 4. However, Granite Harbour Intrusives in the Queen Maud and Pensacola mountains contain late Grenvillian xenocrysts (with those in the Queen Maud Mountains in the range ca 950-1100 Ma; van Schmus et al., 1997) presumably from melting a primary or secondary Grenvillian source. Thus, the Granite Harbour Intrusives in these southern parts of the Ross Orogen could have supplied both the late Panafrican and late Grenvillian populations to the adjacent sedimentary units, and as well (we suggest) to the Lachlan Ordovician turbidites.

Small numbers of 1600-2000 Ma and 2000-2600 Ma zircons in sequence 4 and Lachlan Ordovician turbidites were most likely sourced from the Mawson Craton described by Boger (2011), and either recycled through sequences 2-3 into sequence 4 of the Ross Orogen, or were continually derived from that craton.

Input from Granite Harbour Intrusives in the Queen Maud Mountains is supported by Figure 34k, a 400-700 Ma plot of zircon grains analysed by Paulsen et al. (2013). This plot shows a dominant age peak at $504 \mathrm{Ma}$ (coinciding with a major peak in three samples of the Liv Group; Figure 34i) a smaller $536 \mathrm{Ma}$ peak and a saddle between them at $529 \mathrm{Ma}$.

Finally, the presence of small numbers of mafic-and alkaline-derived zircons in the Lachlan Ordovician turbidites could have been derived from rift volcanics in East Antarctica and/or from mafic parts of the continental margin arc, either directly, or indirectly since these grains also occur in the Ross Orogen sediments. However, most of the alkaline-volcanic derived zircons are older than $557 \mathrm{Ma}$, the oldest recorded intrusion of the Koettlitz Glacier Alkaline Province, thus restricting this as a dominant source.

\section{The Ross Orogen-eastern Lachlan Orogen distributary system}

Our view of the distributary system for these more outboard Lachlan Ordovician turbidite terranes is that they were deposited from submarine fan systems in outboard parts of the Ross Orogen forearc basin, the inboard parts of which consisted of sequence 4 sedimentary units. The eastern Lachlan Ordovician turbidites could have been fed either directly from the source rocks, cutting through the arc, or indirectly via shallow-water rocks of sequence 4 such as the upper Byrd Group. We infer that these distributary systems then flowed north along the plate boundary, before deviation and deposition in backarc settings in the Lachlan Orogen (Glen, 2013) (Figure 30). Using the 165 Ma reconstruction of White, Gibson \& Lister (2013), this involved transport distances ranging from $\sim 2500$ to $3400 \mathrm{~km}$, from Queen Maud Mountains to southern Victoria or central northern NSW. 
Although we suggest long-range sedimentary transport, the northward translation of separate terranes after turbidite deposition is another possibility. However, we tend to discount this, based on the presence of other distributary systems tentatively identified by the same populations of late Panafrican and late Grenvillian zircons plus, where available, the same Hf patterns. We cautiously suggest that before Cretaceous breakup, paleocurrents may have flowed not only north into the Lachlan Orogen and into the South Island of New Zealand, but also into Marie Byrd Land in West Antarctica. In the South Island of New Zealand (NZ, Figure 30), detrital zircons especially from Ordovician turbidites in the Buller Terrane (Nebel-Jacobsen, Münker, Nebel \& Mezger, 2011), and to a lesser extent, from late Cambrian and younger units in the Takaka Terrane (Adams, Mortimer, Campbell \& Griffin, 2015) show similar late Panafrican and late Grenvillian U-Pb populations. Although Adams et al. (2015) proposed derivation from underlying proto-Zealandia basement (unlike the oceanic substrate inferred for Lachlan Ordovician turbidites; e.g. Glen, 2013), comparison with data in this paper suggests the likelihood of East Antarctic sources.

In West Antarctica, sedimentary rocks with similar late Panafrican and late Grenvillian zircon populations occur in the Ross Province of Marie Byrd Land (part of RS, Figure 30), in the preDevonian, undated Swanson Formation that has been correlated with Ordovician units in New Zealand (Yakymchuk et al., 2015). To take one example, their sample Y2MD092 shows a dominant Panafrican detrital zircon population (ca 520-680 Ma, with age peaks at 528, 554 585, $638 \mathrm{Ma}$ and positive to negative values of $\varepsilon_{\mathrm{Hf}}$ ), a secondary Grenvillian detrital zircon population (ca 960-1200 Ma, with age peaks at 1044 and $1137 \mathrm{Ma}$, with positive values of $\varepsilon_{\mathrm{Hf}}$ ), and with a minor grouping of 1600-1700 Ma zircons (Yakymchuk et al., 2015).

The Ellsworth Mountains in West Antarctica (dark grey part of EWM, Figure 30) formed along strike from the Ross Orogen, but have since been rotated through $\sim 90^{\circ}$ during opening of the Weddell Sea (Curtis, 2001). Zircon data reported by Flowerdew et al. (2007) show juvenile Grenvillian $\varepsilon_{\mathrm{Hf}}$ data and mixed juvenile and continental crustal Panafrican $\varepsilon_{\mathrm{Hf}}$ data. Late Panafrican zircons show a significant change from more juvenile to more evolved $\varepsilon_{\mathrm{Hf}}$ values passing upsection from the lower-upper Cambrian Heritage Group into the overlying upper Cambrian to Devonian Crashite Group. This change mirrors that between Lower and upper Middle Ordovician samples in the Hermidale Terrane and Albury-Bega Terrane east in the Lachlan Orogen, but whether it was sourced from the same region of East Antarctica is unknown.

\section{Final note: Gnalta Shelf versus Lachlan Ordovician turbidites}

The Lower Ordovician Gnalta Shelf rocks stand apart from the Lower Ordovician Lachlan Ordovician turbidites by: i) the dominance (70-80\%) of zircons derived from low-silica granitoid melts, and the minor contribution of other sources (compare Figures 7 and 33); ii) the presence of significant numbers of early Grenvillian grains with age peaks at 1180 Ma in Scropes Range Formation and $1177 \mathrm{Ma}$ in the Yandaminta Quartzite (Figure 34b2); iii) with one exception, the youngest grains being older than youngest grains in the Bendigo and Hermidale terranes and the Albury-Bega Terrane east; and iv) differences in the $\varepsilon_{\text {Hf }}$ plots such as the general lack of Panafrican grains with positive $\varepsilon_{\mathrm{Hf}}$ values and the tight cluster of mafic and syenitic zircons at 600-700 Ma with positive $\varepsilon_{\mathrm{Hf}}$ values (Figure 31). All lead to the suggestion of deposition from independent sources, albeit at a broadly comparable time. 


\section{Conclusions}

1. Zircons from Lower Ordovician sandstones on the Gnalta shelf (Koonenberry Belt, Delamerian Orogen) contain distinctive 1180 and 1177 Ma age peaks not shared by any of other samples in this study. While the sources of the Panafrican population in these rocks are unclear, these early Grenvillian ages suggest a source in the Musgrave Province of central Australia. As suggested by others, there appears to have been a major distributary system emanating from central Australia that supplied detritus to parts of the Adelaide Rift Complex, the Koonenberry Belt and parts of the Thomson Orogen.

2. This Musgrave system was coeval with other distributary systems that supplied detritus to the Ordovician turbidites of the Lachlan Orogen; these turbidites are not downstream equivalents of the Gnalta Shelf rocks. Nor do our data suggest that the Gnalta Shelf samples are downstream equivalents of the deeper water turbidites.

3. All sandstones in the Ordovician turbidites of the Lachlan Orogen were sampled from Lancefieldian-Bendigonian-(Chewtonian) (Lower Ordovician) and Darriwilian (upper Middle Ordovician) time slices, constrained in age by graptolites in the Castlemaine Group (Bendigo Terrane) and by cherts in the Girilambone Group (Hermidale Terrane) and Wagga Group (Albury-Bega Terrane west) and Adaminaby Group (Albury-Bega Terrane east). This enabled us to us to examine any intra-terrane as well as interterrane changes.

4. All of these sandstones contain a dominant population of $c a$ 490-620 Ma zircon grains, called here late Panafrican, and a lesser population of $c a 950-1120$ Ma grains, called here late Grenvillian.

5. Most of these zircons were derived from a mixture of low silica $\left(<65 \mathrm{wt} \% \mathrm{SiO}_{2}\right)$ granitoids, which includes diorites, and high silica $\left(70-75 \mathrm{wt} \% \mathrm{SiO}_{2}\right)$ granitoids, with lesser contributions from mafic and alkaline igneous rocks.

6. While conscious of the limited number of concordant detrital zircon grains, we recognise changes in both $\mathrm{U}-\mathrm{Pb}$ and $\varepsilon_{\mathrm{Hf}}$ ratios upsection within the Hermidale and Albury-Bega terranes. The Bendigo Terrane differs in that the same sources remarkably supplied detritus to the Castlemaine Group over a period of 12-21 Ma, suggesting differences between that terrane and the others.

7. Source regions for the Lachlan Ordovician turbidites must contain late Grenvillian age, mainly juvenile zircons (with positive values of $\varepsilon_{\mathrm{Hf}}$ ), and late Panafrican age zircons with more isotopically evolved compositions and dominantly negative values of $\varepsilon_{\mathrm{Hf}}$. These joint criteria rule out any significant input from Australia. Instead they indicate that the most significant sources of all our turbiditic sandstones lay in East Antarctica.

8. The identification of potential East Antarctic sources would be challenging, even if there were no ice cover. With that in mind, we make the following tentative conclusion that sandstones in the Bendigo Terrane, with their relatively consistent $\mathrm{U}-\mathrm{Pb}$ and $\mathrm{Hf}$ ratios in late Panafrican zircons, were derived from inland sources, such as found in western and central Dronning Maud Land, Sør Rondane and extensions inland, where melting of 1.1-1.9 Ga crust in late Grenvillian and late Panafrican times produced juvenile upper 
Grenvillian age rocks that were reworked by late Panafrican age belts, coupled with limited 600-700 Ma rift igneous rocks. Three sandstone samples in the Bendigo Terrane are characterised by consistent 485, 486 and 489 Ma ages of the youngest zircon grains, and by two almost identical late Panafrican peak ages: one of 485, 488 and $494 \mathrm{Ma}$ and the other of 541,546, and $550 \mathrm{Ma}$. The latter 3 peaks plot close to the 535 Ma granite peak of Jacobs et al. (2015) in the Dronning Maud Land that avoids the saddle of the eastern Lachlan Ordovician turbidites.

9. Sandstones in the Hermidale and Albury-Bega terranes have much greater variation in the ages of the youngest zircons and in zircon $\mathrm{U}-\mathrm{Pb}$ and $\mathrm{Hf}$ data, and are thought to have been sourced within, or inboard of, the Neoproterozoic-Cambrian Ross Orogen, developed along part of the Cambrian Gondwana-Pacific plate margin. The remainder of the conclusions concerns these two terranes.

10. Our suggested sources for the Hermidale and Albury-Bega terranes are a combination of igneous and sedimentary sources within the Ross Orogen, and nearby external, inland sources. Igneous (primary) sources within the Ross Orogen include: i) ca 650670 Ma rift volcanics within sequence 2 ; ii) the largely eroded volcanic carapace of the Ross Orogen arc; and iii) late Panafrican <545 Ma Granite Harbour Intrusives, generated from juvenile mantle-derived material derived by subduction melting that was mixed to varying degrees with older and more evolved crustal material in the overriding plate (and/or with some subducted sediments). In the Queen Maud and Pensacola mountains, melting of continental 1.2-2.0 Ga basement crust supplied the late Grenvillian xenocrystic zircons. This basement may be an extension of belt PD3, or even Dronning Maud Land. Secondary sources in the Ross Orogen are represented by (meta)sedimentary units of sequences 2 and 3 derived from inland sources such as central and western Dronning Maud Land, Sør Rondane or PD3.

11. The upper Middle Ordovician samples in the Hermidale Terrane and Albury-Bega Terrane east were sourced from late Panafrican granitoids melted from Archean (2.6$3.0 \mathrm{Ga}$ ) crust. The absence of these sources in lower Ordovician turbidites in the same terranes might simply reflect changing distributary systems or something more fundamental such as variable exhumation. The location of this old crust is intriguing, with the central and eastern Dronning Maud Land a possible candidate.

12. The excellent correlation between zircons in the Hermidale and Albury-Bega terranes and in sequence 4 in the southern Ross Orogen allows us to suggest that this sequence, with its already-premixed zircon populations, is a likely source of these eastern Ordovician turbidites. In particular, we note almost all eastern Ordovician samples show changes in zircon numbers at 540-550 Ma, with zircons $<550 \mathrm{Ma}$ a distinguishing feature of sequences 3 and 4 in the Ross Orogen. We thus suggest that distributary systems flowing across and within the continental margin arc deposited the Liv and upper Byrd groups in the continental and /shallow-water parts of the intra-arc-and forearc basins. The same systems could have continued into deepwater parts of the forearc basin, generating some turbidity currents that tracked northwards along the continental margin into the Lachlan Orogen, and others that tracked outboard into parts of New Zealand, Marie Byrd Land and possibly the Ellsworth Mountains. An alternative interpretation is that the sources that fed the Liv and upper Byrd groups also fed the eastern Lachlan Ordovician turbidites. Another possibility is that the Ross- 
Lachlan distributary system was initiated after abandonment of the Liv and upper Byrd one. However, the 480-490 Ma young grains of sequence 4 in the RossOrogen overlap with those of the Lachlan Ordovician turbidites, suggesting synchronous deposition.

13. Using the 165 Ma reconstruction of White et al. (2013), the Ross-Lachlan system involved transport distances ranging from $\sim 2500$ to $3400 \mathrm{~km}$ (from Queen Maud Mountains to southern Victoria or central northern NSW).

14. The triggers for the major changes in zircon age patterns across the sequence 3-4 and 2-3 boundaries in the Ross Orogen, and thus by extension the onset of deposition of the Lachlan Ordovician turbidites, were probably responses to a significant geodynamic change during the later stages of Gondwana assembly, perhaps reflecting suturing events and/or a switch from contractional to extensional tectonics in Gondwanan collisional orogens.

\section{Acknowledgments}

We thank Elena Belousova, Cameron Quinn, Ian Percival and Michael Bruce for discussions and assistance. Sample analysis was funded by a Macquarie University External Collaborative Research Grant and by a collaborative project with the Geological Survey of NSW, New South Wales Trade and Investment, where Glen worked before his retirement. Use of QEMSCAN scanning technology, now owned by FEI, was facilitated by Alan Butcher in a trial survey with the GSNSW. U-Pb data from zircons in Mum1 were kindly analysed by Yoann Greau. Zircons from Murrawombie1 and TrittonNE were collected with Straits Resources and Phil Jones, and analysed by Elena Belousova, with permission to use the data kindly given by Straits Resources through Chris Raymond. Samples from the Wagga Group and the Castlemaine Group were collected with Jeff Vassallo, the latter with assistance from Fons VandenBerg. The Gnalta Shelf samples were collected with Kingsley Mills, while sample Te2 was located by Steve Trigg. Collection of the BUN samples was based on mapping by Trangie Johnston and paleontology by Ian Percival. We thank Ross Cayley and Gordon Packham for their helpful reviews, especially Gordon who in his painstaking first review asked questions and suggested changes, which encouraged us to restructure our paper and to assemble more detailed $\mathrm{U}-\mathrm{Pb}$ and $\mathrm{Hf}$ data from potential source regions. This is contribution 875 from the ARC Centre of Excellence for Core to Crust Fluid Systems (www.ccfs.mq.edu.au) and contribution 1125 from the GEMOC National Key Centre (www.gemoc.mq.edu.au). It is also a contribution to IGCP project 648 on "Supercontinent Cycles and Geodynamics". The analytical data were obtained using instrumentation funded by DEST Systemic Infrastructure Grants, ARC LIEF, NCRIS/AuScope, industry partners and Macquarie University.

\section{References}

Adams, C. J., Bradshaw, J. D., \& Ireland, T. R. (2014). Provenance connections between late Neoproterozoic and early Paleozoic sedimentary basins of the Ross Sea Region, Antarctica, southeast Australia and southern Zealandia. Antarctic Science, 26, 173-182.

Adams, C. J., Mortimer, N., Campbell, H. J., \& Griffin, W. L. (2015). Detrital zircon ages in Buller and Takaka terranes, New Zealand: constraints on early Zealandia history. New Zealand Journal of Geology and Geophysics, 58, 176-201.Allibone, A. H. \& Wysoczanski, R. (2002). Initiation of magmatism during the Cambrian-Ordovician Ross orogeny in southern Victoria Land, Antarctica. 114, 1007-1018. 
Allibone, A. H., Cox, S. C., Graham, I. J., Smellie, R. W., Johnstone, R. D., Ellery, S. G., \& Palmer K. (1993). Granitoids of the Dry Valleys Area, Southern Victoria Land, Antarctica: Plutons, field relationships, and isotopic dating. New Zealand Journal of Geology and Geophysics, 36, 281-297.

Andersen, T. (2002). Correction of common $\mathrm{Pb}$ in $\mathrm{U}-\mathrm{Pb}$ analyses that do not report ${ }^{204} \mathrm{~Pb}$. Chemical Geology, 192, 59-79.

Andersen, T. (2005). Detrital zircons as tracers of sedimentary provenance: limiting conditions from statistics and numerical simulation. Chemical Geology, 216, 249-270.

Arndt, N. T., Todt, W., Chauvel, C., Tapfer, M., \& Weber, K. (1991). U-Pb zircon age and Nd isotopic composition of granitoids, charnockites and supracrustal rocks from Heimefrontfjella, Antarctica. Geologische Rundshau, 80, 759-777.

Baba, S., Hokada, T., Kaiden, H., Dunkley, D. J., Owada, M., \& Shiraishi, K. (2010). SHRIMP U-Pb dating of sapphirine-bearing granulite and biotitehornblende gneiss in the Schirmacher Hills, East Antarctica: implications for Neoproterozoic ultra-high-temperature metamorphism prefacing the assembly of Gondwana. Journal of Geology, 118, 621-639.

Barovich, K. M., \& Foden, J. (2000). A late Proterozoic continental flood basalt province in Southern Central Australia: geochemical and Nd isotope evidence from Neoproterozoic basin fill. Precambrian Research, 100, 213-234.

Belousova, E. A., Reid, A. J., Griffin, W. L., \& O'Reilly, S. Y. (2009). Rejuvenation vs. recycling of Archean crust in the Gawler Craton, South Australia: Evidence from U-Pb and Hf isotopes in detrital zircon. Lithos, 113, 570-582.

Belousova, E. A., Walters, S., Griffin, W. L., O'Reilly, S. Y., \& Fisher, N. I. (2002). Igneous zircon: zircon trace-element compositions as indicators of source rock type. Contributions to Mineralogy and Petrology, 143, 602-622.

Berry, R. F., Steele, D. A. \& Meffre, S. (2008). Proterozoic metamorphism in Tasmania: Implications for tectonic reconstructions. Precambrian Research, 166, 387-396.

Bizzarro, M., Baker, J. A., Haack, H., Ulfbeck, D., \& Rosing, M. (2003). Early history of Earth's crust-mantle system inferred from hafnium isotopes in chondrites. Nature, 421, 931-933.

Black, L. P. (2007). SHRIMP U-Pb zircon ages obtained during 2006/2007 for NSW Geological Survey projects. Maitland NSW: Unpublished report GSNSW 2007/298.

Black, L. P., \& Sheraton, J. W. (1990). The influence of Precambrian source components on the U$\mathrm{Pb}$ zircon age of a Palaeozoic granite from northern Victoria Land, Antarctica. Precambrian Research, 46, 275-293.

Black, L. P., Calver, C. R., Seymour, D. B., \& Reed, A. (2004). SHRIMP U-Pb detrital zircon ages from Proterozoic and Early Palaoeozoic sandstones and their bearing on the geological evolution of Tasmania. Australian Journal of Earth Sciences, 51, 885-900.

Black, L. P., Everard, J. L., McClenaghan, M. P., Korsch, R. J., Calver, C. R., Fioretti, A. M., Brown, A. V., \& Foudoulis, C. (2010). Controls on Devonian-Carboniferous magmatism in Tasmania, based on inherited zircon age patterns, $\mathrm{Sr}, \mathrm{Nd}$ and $\mathrm{Pb}$ isotopes, and major and trace element geochemistry. Australian Journal of Earth Sciences, 57, 933-968.

Black, L. P., McClenaghan, M. P., Korsch, R. J., Everard, J. L., \& Foudoulis, C. (2005). The significance of Devonian-Carboniferous igneous activity in Tasmania, as derived from U$\mathrm{Pb}$ SHRIMP dating of zircon. Australian Journal of Earth Sciences, 52, 807-829.

Black, L. P., Seymour, D. B., Corbett, K. D., Cox, S. E., Streit, J. E., Bottrill, R. S., Calver, C. R., Everard, J. L., Green, G. R., McClenaghan, M. P., Pemberton, J., Taheri, J., \& Turner, N. J. (1997). Dating Tasmania's oldest geological events. Australian Geological Survey Organisation Record 1997/15. Canberra ACT: AGSO. 
Blewett, R. S., Black, L. P., Sun, S.-S., Knutson, J., Hutton, L. J., \& Bain, J. H. C. (1998). U-Pb zircon and Sm-Nd geochronology of the Mesopoterozoic of north Queensland: implications for a Rodinian connection with the Belt Supergroup of North America. Precambrian Research, 89, 101-127.

Boger, S. D. (2011). Antarctica-before and after Gondwana. Gondwana Research, 19, 335-371.

Bomparola, R. M.,\& Ghezzo, C. (2007). Inside the Granite Harbour Intrusives of northern Victoria Land: Timing and origin of the intrusive sequence. In K. A. Cooper \& C. R. Raymond et al.(Eds.) Antarctica: A Keystone in a Changing World. Abstract 043. Online Proceedings of the $10^{\text {th }}$ ISAES.US Geological Survey Open File Report 2007-1047. https://pubs.usgs.gov/of/2007/1047

Bomparola, R. M., Ghezzo, C., Belousova, E., Griffin, W. L. \& O'Reilly, S. Y. (2007). Resetting of the U-Pb zircon system in Cambro-Ordovician intrusives of the Deep Freeze Range, northern Victoria Land, Antarctica. Journal of Petrology, 48, 327-364.

Borg, S. G., \& DePaolo, D. J. (1991). A tectonic model of the Antarctic Gondwana margin with implications for southeastern Australia: isotopic and geochemical evidence. Tectonophysics, 196, 339-385.

Borg, S. G., \& DePaolo, D. J. (1994). Laurentia, Australia, and Antarctica as a Late Proterozoic supercontinent - constraints from isotopic mapping. Geology, 22, 307-310.

Borg, S. G., DePaolo, D. J., \& Smith, B. M. (1990). Isotope structure and tectonics on the central Transantarctic Mountains. Journal of Geophysical Research, 95, 6647-6667.

Borg, S. G., Stump, E., Chappell, B. W., McCulloch, M. T., Wyborn, D., Armstrong, R. L., \& Holloway, J. R. (1987). Granitoids of northern Victoria Land, Antarctica: Implications of chemical and isotopie variations to regional crustal structure and tectonics. American Journal of Science, 287, 127-169.

Bracciali, L., Di Vincenzo, G., Rocchi, S., \& Ghezzo, C. (2009). The Tiger Gabbro from northern Victoria Land, Antarctica: the roots of an island arc within the early Palaeozoic margin of Gondwana. Journal of the Geological Society of London, 166, 711-724.

Brown, D., Purdy, D., Carr, P., Cross, A., \& Kositcin, N. (2014). New isotopic data from Thomson Orogen basement cores: a possible link with the Centralian Superbasin. Abstracts of the Geological Society of Australia, 110, 243-244.

Brown, A. V., \& Jenner, G. A. (1989). Geological setting, petrology and chemistry of Cambrian high-magnesian andesite and low-titanium tholeiite lavas in western Tasmania. In A. J. Crawford (Ed.) Boninites and Related Rocks (pp. 233-263). Boston Ma: Unwin Hyman.

Bruce, M. C., \& Percival, I. G. (2014). Geochemical evidence for provenance of Ordovician cherts in southeastern Australia. Australian Journal of Earth Sciences, 61, 927-950.

Burton, G. R., Trigg, S. J., \& Campbell, L. M. (2012). Sussex and Byrock 1:100 000 geological sheets, 1st edition, Explanatory Notes. Maitland, NSW: Geological Survey of New South Wales.

Camacho, A., Hensen, B. J., \& Armstrong, R. (2002). Isotopic test of a thermally driven intraplate orogenic model, Australia. Geology, 30, 887-890.

Cas, R. A. F., Powell, C. M. \& Crook, K. a. W. (1980). Ordovician palaeogeography of the Lachlan Fold Belt a modern analogue and tectonic constraints. Journal of the Geological Society of Australia, 27, 1932.

Cawood, P. A., \& Korsch, R. J. (2008). Assembling Australia: Proterozoic building of a continent. Precambrian Research, 166,1-38.

Cayley, R. A. (2011). Exotic crustal block accretion to the eastern Gondwanaland margin in the Late Cambrian - Tasmania, the Selwyn Block, and implications for the Cambrian-Silurian evolution of the Ross, Delamerian, and Lachlan orogens. Gondwana Research, 19, 628-649. 
Cayley, R. (2014). Emerging geological concepts, and how they are changing Victorian gold and base metals prospectivity. https://www.aig.org.au/wpcontent/uploads/2014/09/Cayley-The-Lachlan-Orocline-of-Eastern-Australiapresentation.pdf. In New Perspectives Workshop, September 2014. Romsey Victoria: Presented by AIG Victoria and AusIMM Central Victoria Branch.

Cayley, R. A., J., K. R., Kennett, B., Skladzien, P., Jones, L., Morand, V. J., Gibson, G., Rawling, T. J. \& Betts, P. G. (2011). Results of deep seismic reflection imaging of the eastern Delamerian Orogen, South Australia and western Victoria. Data CD version: 4 March 2011. Melbourne Vic: Geoscience Victoria, Department of Primary industries.

Cayley, R. A., Korsch, R. J., Moore, D. H., Costelloe, R. D., Nakamura, A., Willman, C. E., Rawling, T. J., Morand, V. J., Skladzien, P. B., \& O'Shea, P. J. (2011). Crustal architecture of central Victoria: results from the 2006 deep crustal reflection seismic survey. Australian Journal of Earth Sciences, 58, 113-156.

Cayley, R. A., Taylor, D. H., Vandenberg, A. H. M., \& Moore, D. H. (2002). Proterozoic-early Palaeozoic rocks and the Tyennan orogeny in central Victoria. The Selywn Block \& its tectonic implications. Australian Journal of Earth Sciences, 49, 225-254.

Clark, D. J., Hensen, B. J., \& Kinny, P. D. (2000). Albany-Fraser orogen. Precambrian Research, 102, 155-183.

Cobb, M. M., Cawood, P. A., Kinny, P. D., \& Fitzsimons, I. C. W. (2001). SHRIMP U-Pb zircon ages from the Mullingarra Complex, Western Australia: isotopic evidence for allochthonous blocks in the Pinjarra Orogen and implications for East Gondwana assembly. Abstracts of the Geological Society of Australia, 64, 21-22.

Collins, A. S. \& Pisarevsky, S. A. (2005). Amalgamating eastern Gondwana: the evolution of the Circum-Indian Orogens. Earth Science Reviews, 71, 229-270.

Colquhoun, G. P., Fergusson, C. L., \& Tye, S. C. (1999). Provenance of early Palaeozoic sandstones, southeastern Australia. Part 2: Cratonic to arc switching. Sedimentary Geology, 125, 153163.

Coney, P. J., Edwards, A., Hine, R., Morrison, F., \& Windrim, D. (1990). The regional tectonics of the Tasman orogenic system, eastern Australia. Journal of Structural Geology, 12, 519-543.

Cook, Y. A. (2007). Precambrian rift-related magmatism and sedimentation, southern Victoria Land, Antarctica. Antarctic Science, 19, 471-484.

Cook, Y. A., \& Craw, D. (2001). Amalgamation of disparate crustal fragments in the Walcott BayFoster Glacier area, Southern Victoria Land, Antarctica. New Zealand Journal of Geology \& Geophysics, 44, 403-416.

Cooper, A. F., Maas, R., Scott, J. M., \& Barber, A. J. W. (2011). Dating of volcanism and sedimentation in the Skelton Group, Transantarctic Mountains: implications for the Rodinia-Gondwana transition in southern Victoria Land, Antarctica. Geological Society of America Bulletin, 123, 681-702.

Corbett, K. D., \& Vicary, M. J. (2014). Middle Cambrian post-collisional volcanism and sedimentation. In K. D. Corbett, P. G. Quilty \& C. R. Calver (Eds.) Geological evolution of Tasmania (pp. 145-183). Geological Society of Australia Special Publication 24. Hobart Tas: Geological Society of Australia.

Cottle, J. M., \& Cooper, A. F. (2006). The Fontaine Pluton: an early Ross Orogeny calc-alkaline gabbro from southern Victoria Land, Antarctica. New Zealand Journal of Geology and Geophysics, 49, 177-189. 
Cox, S. C., Parkinson, D. L., Allibone, A. H., \& Cooper, A. F. (2000). Isotopic character of CambroOrdovician plutonism, southern Victoria Land, Antarctica. New Zealand Journal of Geology and Geophysics, 43, 501-520.

Crawford, A. J., \& Berry, R. F. (1992). Tectonic implications of Late Proterozoic-early Palaeozoic igneous rock associations in western Tasmania. Tectonophysics, 214, 37-56.

Crawford, A. J., \& Keays, R. R. (1987). Petrogenesis of Victorian Cambrian tholeiites and implications for the origin of associated boninites. Journal of Petrology, 28, 1175-1109

Crawford, A. J., Donaghy, A. G., Black, L., \& Stuart-Smith, P. (1996). Mt Read Volcanics correlates in western Victoria: a new exploration opportunity. Bulletin Australian Institute of Geoscientist, 20, 97-102.

Crawford, A. J., Stevens, B. P. J., \& Fanning, M. (1997). Geochemistry and tectonic setting of some Neoproterozoic and Early Cambrian volcanics in western New South Wales. Australian Journal of Earth Sciences, 44, 831-852.

Curtis, M. L. (2001). Tectonic history of the Ellsworth Mountains, West Antarctica: Reconciling a Gondwana enigma. Geological Society of America Bulletin, 113, 939-958.

Curtis, M. L., Millar, I. L., Storey, B. C., \& Fanning, C. M. (2004). Structural and geochronological constraints of early Ross orogenic deformation in the Pensacola Mountains, Antarctica. Geological Society of America Bulletin, 116, 619-636.

De Wit, M. J., Bowring, S. A., Ashwal, L. D., Randrianasolo, L. G., Morel, V.P. I., \& Rambelson, R. A. (2001). Age and tectonic evolution of Neoproterozoic ductile shear zones in southwestern Madagascar, with implications for Gondwana studies Tectonics, 20, 1-45.

Direen, N. G., \& Crawford, A. J., (2003). Fossil seaward dipping reflector sequences preserved in southeastern Australia. Journal of the Geological Society of London, 160, 985-990.

Di Vincenzo, G., Grande, A., \& Rossetti, F. (2014). Paleozoic siliciclastic rocks from northern Victoria Land (Antarctica): Provenance, timing of deformation, and implications for the Antarctica-Australia connection. Geological Society of America Bulletin, 126, 1416-1438.

Draper, J. J. (2006). The Thomson Fold Belt in Queensland revisited. AESSC2006, CD-ROM extended abstract. Melbourne Vic: Geological Society of Australia, $6 \mathrm{p}$.

Durocher, E., Kyser, T. K., Marlatt, J., \& Hanly, A. (2003). New ${ }^{40} \mathrm{Ar} /{ }^{39} \mathrm{Ar}$ ages from the central Paterson Orogen, Western Australia. Australian Journal of Earth Sciences, 50, 601-610.

Edwards, J., Wohlt, K. E., Slater, K. R., Olshina, A., \& Hutchinson, D. F. (1998). Heathcote and parts of Woodend and Echuca 1:100 000 map area geological report. Geological Survey of Victoria Report, 108, 212 pp. Melbourne Vic: Geological Survey of Victoria.

Elburg, M., Jacobs, J., Andersen, T., Clark, C., Läufer, A., Ruppel, A. S., Krohne, N., \& Damaske, D. (2015). Early Neoproterozoic metagabbro-tonalite-trondhjemite of Sør Rondane (East Antarctica): Implications for supercontinent assembly. Precambrian Research, 595, 189206.

Elliott, D. H. (2013). The geological and tectonic evolution of the Transantarctic Mountains: a review. In M. J. Hambrey, P. F. Barker, P. J. Barrett, V. Bowman, B. Davies, J. L. Smellie \& M. Tranter (Eds.) Antarctic Palaeoenvironments and Earth-Surface Processes (pp. 7-35). London UK: Geological Society London, Special Publication 381.

Elliot, D. H., Fanning, C. M., \& Hulett, S. R. W. (2015). Age provinces in the Antarctic craton: Evidence from detrital zircons in Permian strata from the Beardmore Glacier region, Antarctica. Gondwana Research, 28, 152-164.

Encarnacion, J., \& Grunow, A. (1996). Changing magmatic and tectonic styles along the paleoPacific margin of Gondwana and the onset of early Paleozoic magmatism in Antarctica. Tectonics, 15, 1325-1341. 
Encarnación, J., Rowell, A. J., \& Grunow, A. (1999). A U-Pb age for the Cambrian Taylor Formation, Antarctica: implications for the Cambrian time scale. Journal of Geology, 107, 497-504.

Estrada, S., Läufer, A., Eckelmann, K., Hofmann, M., Gärtner, A., \& Linnemann, U. (2015). Continuous Neoproterozoic to Ordovician sedimentation at the East Gondwana margin Implications from detrital zircons of the Ross Orogen in northern Victoria Land, Antarctica. Gondwana Research, 37, 426-448

Fanning, C. M., Goodge, J. W., \& Vervoort, J. D. (2015). Proterozoic crustal history of central East Antarctica. Abstract Volume XII Intenational Symposium on Antarctic Earth Sciences, 1317 July 2015 (pp. 29-30). Goa, India.

Felton, E. A. (1981). Geology of the Canbelego 1:100 000 sheet 8134. Sydney NSW: Geological Survey of New South Wales.

Fergusson, C. L. (1998). Cambrian-Silurian oceanic rocks, upper Howqua River, eastern Victoria: tectonic implications. Australian Journal of Earth Sciences, 45, 633-644.

Fergusson, C. L. (2003). Ordovician-Silurian accretion tectonics of the Lachlan Fold Belt, southeastern Australia. Australian Journal of Earth Sciences, 50, 475-490.

Fergusson, C. L. (2009).Tectonic evolution of the Macquarie Arc, central New South Wales: arguments for subduction polarity and anticlockwise rotation. Australian Journal of Earth Sciences, 56, 179-193.

Fergusson, C. L., \& Phillips, D. (2001). ${ }^{40} \mathrm{Ar} /{ }^{39} \mathrm{Ar}$ and $\mathrm{K}-\mathrm{Ar}$ age constraints on the timing of regional deformation, south coast of New South Wales, Lachlan Fold Belt: problems and implications. Australian Journal of Earth Sciences, 48, 395-408.

Fergusson, C. L., \& Tye, S. C. (1999). Provenance of early Palaeozoic sandstones, southeastern Australia. Part 1: vertical changes through the Bengal fan-type deposit. Sedimentary Geology, 125, 135-151.

Fergusson, C. L., Carr, P. F., Fanning, C. M., \& Green, T. J. (2001). Proterozoic-Cambrian detrital zircons and monzonite ages from the Anakie Inlier central Queensland: Grenville and Pacific-Gondwana signatures. Australian Journal of Earth Sciences, 48, 857-866.

Fergusson, C. L., Fanning, C. M., Phillips, D., \& Ackerman, B. (2005). Structure, detrital zircon U$\mathrm{Pb}$ ages and ${ }^{40} \mathrm{Ar} /{ }^{39} \mathrm{Ar}$ geochronology of the early Palaeozoic Girilambone Group, central New South Wales: subduction, contraction and extension associated with the Benambran Orogeny. Australian Journal of Earth Sciences, 52, 137-159.

Fergusson, C. L., Henderson, R. A., Fanning, C. M., \& Withnall, I. W. (2007). Detrital zircon ages in Neoproterozoic to Ordovician siliclastic rocks, northeastern Australia: implications for the tectonic history of the East Gondwana continental margin. Journal of the Geological Society, London, 164, 215-225.

Fergusson, C. L., Nutman A. P., Kamiichi T., \& Hidaka, H. (2013). Evolution of a Cambrian active continental margin: The Delamerian-Lachlan connection in southeastern Australia from a zircon perspective. Gondwana Research, 24, 1051-1066.

Fitzsimons, I. (2016). Pan-African granulites of Madagascar and southern India: Gondwana assembly and parallels with modern Tibet. Journal of Mineralogical and Petrological Sciences, 111, 73-88.

Fitzsimons, I. C. W. (2003). Proterozoic basement provinces of southern and southwestern Australia, and their correlation with Antarctica. In M. Yoshida, B. F. Windley \& S. Dasgupta (Eds.) Proterozoic East Gondwana: Supercontinent Assembly and Breakup (pp. 93-130). London UK: Geological Society London, Special Publication 206. 
Flöttmann, T., \& James, P. R. (1997). Influence on basin architecture on the style of inversion and fold-thrust belt tectonics-the southern Adelaide Fold-Thrust Belt, South Australia. Journal of Structural Geology, 19, 1093-1110.

Flöttmann, T., Haines, P. W., Cockshell, C. D., \& Preiss, W. V. (1998b). Reassessment of the seismic stratigraphy of the Early Palaeozoic Stansbury Basin, Gulf St Vincent, South Australia. Australian Journal of Earth Sciences, 45, 547-557.

Flöttmann, T., Haines, P., Jago, J., James, P., Belperio, A., \& Gum, J. (1998a). Formation and reactivation of the Cambrian Kanmantoo Trough, SE Australia: implications for early Palaeozoic tectonics at eastern Gondwana's plate margin. Journal of the Geological Society, London, 155, 525-539.

Flowerdew, M. J., Millar, I. L., Curtis, M. L., Vaughan, A. P. M., Horstwood, M. S. A., Whitehouse, M. J., \& Fanning, C. M. (2007). Combined U-Pb and Hf isotope geochemistry of detrital zircons from early paleozoic sedimentary rocks, Ellsworth-Whitmore Mountains block, Antarctica. Geological Society of America Bulletin, 119, 275-288.

Foden, J., Sandiford, M., Dougherty-Page, J., \& Williams, I. (1999). Geochemistry and geochronology of the Rathjen Gneiss: implications for the early tectonic evolutionof the Delamerian Orogen. Australian Journal of Earth Sciences, 46, 377-389.

Foden, J. D., Elburg, M. A., Turner, S. P., Sandiford, M., O Callagahan, J. O., \& Mitchell, S. (2002). Granite production in the Delamerian Orogen, South Australia. Journal of the Geological Society, London, 159, 557-575.

Foden, J., Elburg, M. A., Dougherty-Page, J., \& Burtt, A. (2006). The Timing and Duration of the Delamerian Orogeny: Correlation with the Ross Orogen and Implications for Gondwana Assembly. The Journal of Geology, 14, 189-210.

Foster, D. A., Gray, D. R., Kwak, T. A. P., \& Bucher, M. (1998). Chronology and tectonic framework of turbidite-hosted gold deposits in the Western Lachlan Fold belt, Victoria: ${ }^{40} \mathrm{Ar}-{ }^{39} \mathrm{Ar}$ results. Ore Geology Reviews, 13, 229-250.Ghezzo, C., et al. (1987). Granitoids from the David Glacier-Aviator Glacier segment of the Transantarctic Mountains, North Victoria Land, Antarctica. Memorie Della Societa Geografica Italiana, 33, 143-159. 11 author

Giacomini, F., Tiepolo, M., Dallai, L., \& Ghezzo, C. (2007). On the onset and evolution of the Rossorogeny magmatism in Northern Victoria Land Antarctica. Chemical Geology, 240, 103128.

Glen, R. A. (1992). Thrust, extensional and strike-slip tectonics in an evolving Palaeozoic orogen - a structural synthesis of the Lachlan Orogen of southeastern Australia. Tectonophysics, 214, 341-380.

Glen, R. A. (1993). Palaeomagnetism and terranes in the Lachlan Orogen. Exploration Geophysics, 24, 247-256.

Glen, R. A. (1994). Ordovician-earliest Silurian sedimentary rocks. In P. C. Lewis, R. A. Glen, G. W. Pratt, \& I. Clarke (Eds.) Bega-Mallacoota 1:250 000 geological Sheet SI/55-4, SJ/55-8: Explanatory Notes (pp. 17-27). Sydney NSW: Geological Survey of New South Wales.

Glen, R. A. (2005). The Tasmanides of eastern Australia. In A. P. M. Vaughan, P. T. Leat \& R. J. Pankhurst (Eds.) Terrane Processes at the Margins of Gondwana (pp. 23-96). Special Publication of the Geological Society, London 246. London: Geological Society, London.

Glen, R. A. (2013). Refining accretionary orogen models for the Tasmanides of eastern Australia. Australian Journal of Earth Sciences, 60, 315-370.

Glen, R. A., \& VandenBerg, A. H. M. (1987). Thin-skinned tectonics in part of the Lachlan Fold Belt near Delegate, southeastern Australia. Geology, 15, 1070-1073. 
Glen, R. A., \& Wyborn, D. (1997). Inferred thrust imbrication, deformation gradients and the Lachlan Transverse Zone in the eastern belt of the Lachlan Orogen, New South Wales. Australian Journal of Earth Sciences, 44, 49-68.

Glen, R. A., Belousova, E. \& Griffin, W. L. 2016. Different styles of modern and ancient non-collisional orogens and implications for crustal growth: a Gondwanaland perspective. Canadian Journal of Earth Sciences, special issue on "Uniformitarianism and Plate Tectonics: A tribute to Kevin C. Burke and John F. Dewey, 53, 1372-1415.

Glen, R. A., Crawford, A. J., \& Cooke, D. R. (2007). Tectonic setting of porphyry $\mathrm{Cu}-\mathrm{Au}$ mineralisation in the Ordovician-Early Silurian Macquarie Arc, eastern Lachlan Orogen, New South Wales. Australian Journal of Earth Sciences, 54, 465-479.

Glen, R. A., Korsch, R. J., Direen, N. G., Jones, L. E. A, Johnstone, D. W., Lawrie, J. C., Finlayson, D. M., \& Shaw, R. D. (2002). Crustal structure of the Ordovician Macquarie Arc, Eastern Lachlan Orogen, based on seismic-reflection profiling. Australian Journal of Earth Sciences, 49, 323348.

Glen, R. A., Korsch, R. J., Hegarty, R., Saeed, A., Poudjom Djomani, Y., Costelloe, R. D., \& Belousova, E. (2013). Geodynamic significance of the boundary between the Thomson Orogen and the Lachlan Orogen, northwestern New South Wales and implications for Tasmanide tectonics. Australian Journal of Earth Sciences, 60, 371-412.

Glen, R. A., Percival, I. G., \& Quinn, C. D. (2009). Ordovician continental margin terranes in the Lachlan Orogen, Australia: implications for tectonics in an accretionary orogen along the east Gondwana margin. Tectonics, 28, TC6012, doi:10.1029/2009TC002446.

Glen, R. A., Stewart, I. R., \& Vandenberg, A. H. M. (1990). Imbrication of a reference section: Reevaluation of the Adaminaby Beds at El Paso, Dalgety, New South Wales. Journal \& Proceedings of the Royal Society of New South Wales, 123, 15-26.

Glen, R. A., Walshe, J. L., Barron, L. M., \& Watkins, J. J. (1998). Ordovician convergent-margin volcanism and tectonism in the Lachlan sector of east Gondwana. Geology, 26, 751-754.

Goodge, J. W., Fanning, C. M., Brecke, D. M., Licht, K. J., \& Palmer, E. F. (2010). Continuation of the Laurentian Grenville Province across the Ross Sea margin of east Antarctica. The Journal of Geology, 118, 601-619.

Goodge, J. W., Fanning, C. M., Norman, M. D., \& Bennett, V. C. (2012). Temporal, isotopic and spatial relations of early Palaeozoic Gondwana-margin arc magmatism, central Transantarctic Mountains, Antarctica. Journal of Petrology, 53, 2027-2065.

Goodge, J. W., Hansen, V. L., \& Walker, N. W. (1993). Neoproterozoic-Cambrian basementinvolved orogenesis within the Antarctic margin of Gondwana. Geology, 21, 37-40.

Goodge, J. W., Myrow, P., Phillips, D., Fanning, C. M., \& Williams, I. S. (2004a). Siliciclastic record of rapid denudation in response to convergent-margin orogenesis, Ross Orogen, Antarctica. In M. Berne, \& C. Spiegel (Eds.) Detrital Thermochronology - Provenance analysis, exhumation, and landscape evolution of mountain belts (pp. 101-122). Boulder, Colorado: Geological Society of America Special Paper 378.

Goodge, J. W., Myrow, P., Williams, I., \& Bowring, S. (2002). Age and provenance of the Beardmore Group, Antarctica: Constraints on Rodinia supercontinent breakup. Journal of Geology, 110, 393-406.

Goodge, J. W., Vervoort, J. D., Fanning, C. M., Brecke, D. M., Farmer, G. L., Williams, I. S., Myrow, P. M., \& DePaolo, D. J. (2008). A positive test of East Antarctica-Laurentia juxtaposition within the Rodinia supercontinent. Science, 321, 235-240.

Goodge, J. W., Williams, I. S., \& Myrow, P. (2004b). Provenance of Neoproterozoic and lower Paleozoic siliciclastic rocks of the central Ross Orogen, Antarctica: detrital record of rift-, 
passive- and active-margin sedimentation. Geological Society of America Bulletin, 116, $253-$ 1279.

Gray, D. R., \& Foster, D. A. (1998). Character and kinematics of faults within the turbiditedominated Lachlan Orogen: implications for the structural evolution of eastern Australia. Journal of Structural Geology, 20, 1691-1720.

Gray, D. R., \& Foster, D. A. (2004). Tectonic evolution of the Lachlan Orogen, southeastern Australia: historical review, data synthesis and modern perspectives. Australian Journal of Earth Sciences, 51, 773-817.

Greenfield, J. G., \& Percival, I. G. (2010). Bilpa Conglomerate. In J. G. Greenfield, P. J. Gilmore, \& K. J. Mills (Compilers). Explanatory Notes for the Koonenberry Belt geological maps. Geological Survey of New South Wales Bulletin 35. Maitland NSW: Geological Survey of New South Wales.

Greenfield, J. E., Gilmore, P. J., \& Mills, K. J. (Compilers) (2010). Explanatory Notes for the Koonenberry Belt geological maps. Geological Survey of New South Wales Bulletin 35. Maitland NSW: Geological Survey of New South Wales.

Greenfield, J. E., Musgrave, R. G., Bruce, M., Gilmore, P. J., \& Mills, K. J. (2011). The Mount Wright Arc: a Cambrian subduction sys,tem developed on the continental margin of East Gondwana Koonenberry Belt, eastern Australia. Gondwana Research, 19, 650-669.

Griffin, W. L., Belousova, E. A., Shee, S. R., Pearson, N. J., \& O'Reilly, S. Y. (2004). Archean crustal evolution in the northern Yilgarn Craton: $\mathrm{U}-\mathrm{Pb}$ and Hf-isotope evidence from detrital zircons. Precambrian Research, 131, 231-282.

Griffin, W. L., Pearson, N. J., Belousova, E. A., Jackson, S. R., Van Achterbergh, E., O'Reilly, S. Y., \& Shee, S. R. (2000). The Hf isotope composition of cratonic mantle: LAM-MCICPMS analysis of zircon megacrysts in kimberlites. Geochimica et Cosmochimica Acta, 64, 133-147.

Griffin, W. L., Spetius, Z. V., Pearson, N. J., \& O'Reilly, S. Y. (2002). In situ Re-Os analysis of sulfide inclusions in kimberlitic olivine: new constraints on depletion events in the Siberian lithospheric mantle. Geochemistry, Geophysics, Geosystems, 3, doi:10.1029/2001GC000287.

Griffin, W. L., Powell, W. J., Pearson, N. J., \& O'Reilly, S. Y. (2008). GLITTER: data reduction software for laser ablation ICP-MS. In P. Sylvester (Ed.) Laser ablation-ICP-MS in the Earth Sciences (pp. 204-207). Ottawa Canada: Mineralogical Association of Canada Short Course Series, 40, Appendix 2.

Gum, J. C., \& Belousova, E. A. (2006). Musgrave Province Reconnaissance Using TerraneChron ${ }^{\mathrm{TM}}$. Abstract volume of the Australian Earth Science Convention Melbourne, 2006. Extended Abstracts CD, pp 1-8. Sydney NSW: Geological Society of Australia.

Hagen-Peter, G., Cottle, J. M., Tulloch, A. J., \& Cox, S. C. (2015). Mixing between enriched lithospheric mantle and crustal components in a short-lived subduction-related magma system, Dry Valleys area, Antarctica: insights from U-Pb geochronology, Hf isotopes, and whole-rock geochemistry. Lithosphere, 7, 174-188.

Hagen-Peter, G., Cottle, J. M., Smit, M., \& Cooper, A. F. (2016). Coupled garnet Lu-Hf and monazite $\mathrm{U}-\mathrm{Pb}$ geochronology constrain early convergent margin dynamics in the Ross orogen, Antarctica. Journal of Metamorphic Geology, 34, 293-319.

Haines, P. W., Turner, S. P., Foden, J. D., \& Jago, J. B. (2009). Isotopic and geochemical characterisation of the Cambrian Kanmantoo Group, South Australia: implications for stratigraphy and provenance. Australian Journal of Earth Sciences, 56, 1095-1110.

Haines, P. W., Turner, S. P., Kelley, S. P., Wartho, J.-A., \& Sherlock, S. C. (2004). ${ }^{40} \mathrm{Ar}-{ }^{39} \mathrm{Ar}$ dating of detrital muscovite in provenance investigations: a case study from the Adelaide Rift Complex, South Australia. Earth and Planetary Science Letters, 227, 297-311. 
Hall, T. S. (1899). The graptolite-bearing rocks of Victoria, Australia. Geological Magazine, 4 , 438-451.

Harley, S. L., Fitzsimons, I. C. W., \& Zhao, Y. (2013). Antarctica and supercontinent evolution: historical perspectives, recent advances and unresolved issues. In S. L. Harley, I. C. W. Fitzsimons \& Y. Zhao (Eds.) Antarctica and Supercontinent Evolution (pp. 1-34). Geological Society, London, Special Publications 383. London UK: Geological Society, London.

Harris, W. J. (1916). The palaeontologicai sequence of the Lower Ordoviclan rocks of the Castlemaine district, Part I. Proceedings of the Royal Society of Victoria, 29, 50-74.

Henjes-Kunst, F. (2003). Single-crystal Ar-Ar laser dating of detrital micas from metasedimentary rocks of the Ross orogenic belt at the Pacific margin of the Transantarctic Mountains, Antarctica. In D. K. Fütterer, D. Damaske, G. Kleinschmidt, H. Miller \& F. Tessensohn (Eds.) 9th International Symposium on Antarctic Earth Sciences (ISAES IX) Antarctic Contributions to Global Earth Sciences, Programme and Abstracts (pp. 150-151). Potsdam, Germany: Publishers Terra Nostra 2003/4.

Henjes-Kunst, F., \& Schüssler, U. (2003). Metasedimentary units of the Cambro-Ordovician Ross Orogen in northern Victoria Land and Oates Land: Implications for their provenance and geotectonic setting from geochemical and Nd-Sr isotope data. Terra Antarctica, 10, 105128.

Hutton, L., Fanning, C. M., \& Withnall, I. W. (1998). The Cape River area-evidence for Late Mesoproterozoic and Neoproterozoic crust in north Queensland. Abstracts Geological Society of Australia, 48, 216.

Ireland, T. R., Flottmann, T., Fanning, C. M., Gibson, G. M., \& Preiss, W. V. (1998). Development of the early Paleozoic Pacific margin of Gondwana from detrital zircon ages across the Delamerian orogen. Geology, 26, 243-246.Iwata, K., Schmidt, B. L., Leitch, E. C., Allan, A. D., \& Watanabe, T. (1995). Ordovician microfossils from the Ballast Formation (Girilambone Group) of New South Wales. Australian Journal of Earth Sciences, 42, 371-376.

Jacobs, J. (1999). Neoproterozoic/Lower Palaeozoic Events in Central Dronning Maud Land (East Antarctica) Gondwana Research, 2, 473-480.

Jacobs, J. \& Fitzgerald, P. G. (2009). Extensional collapse of the late Neoproterozoic-early Palaeozoic East African-Antarctic Orogen in central Dronning Maud Land, East Antarctica. In M. Yoshida, B. Windley \& S. Dasgupta (Eds.) Proterozoic east Gondwana: Supercontinent Assembly and Breakup (pp. 271-287). London UK: Geological Society of London Special Publication.

Jacobs, J., Elburg, M., Läufer, A., Kleinhanns, I. C., Henjes-Kunst, F., Estrada, S., Ruppel, A. S., Damaske, D., Montero, P., \& Bea, F. (2015). Two distinct Late Mesoproterozoic/Early Neoproterozoic basement provinces in central/eastern Dronning Maud Land, East Antarctica: The missing link, 15-21ํ․ Precambrian Research, 265, 249-272.

Jacobs, J., Fanning, C. M., \& Bauer, W. (2003). Timing of Grenville-age vs. Pan-African medium- to high grade metamorphism in western Dronning Maud Land (East Antarctica) and significance for correlations in Rodinia and Gondwana. Precambrian Research, 125,1-20.

Jacobs, J., Fanning, C. M., Henjes-Kunst, F., Olesch, M., \& Paech, H.-J. (1998). Continuation of the Mozambique Belt into East Antarctica: Grenville-age metamorphism and polyphase PanAfrican high-grade events in central Dronning Maud Land. Journal of Geology, 106, 385406.

Jell, P. A. (2013). Cambrian trilobites of Heathcote District, central Victoria, Australia. Acta Palaeontologica Sinica, 53, 452-485. 
Jones, P. (2012a). Tritton copper mine: mineralisation and host sequence. Post conference field excursion; Geology and mineralisation of the Cobar-Nyngan region. Cobar Regional Mining and Exploration Conference. Cobar: File Geological Survey of NSW GS2012/695. Maitland NSW: Geological Survey of NSW.

Kemp, A. I. S., Hawkesworth, C. J., Collins, W. J., Gray, C. M., \& Blevin, P. L. (2009). Isotopic evidence for rapid continental growth in an extensional accretionary orogen: The Tasmanides, eastern Australia. Earth and Planetary Science Letters, 284, 455-466.

Kirkland, C. L., Smithies, R. H., \& Spaggiari, C. V. (2015). Foreign contemporaries - Unravelling disparate isotopic signatures from Mesoproterozoic Central and Western Australia. Precambrian Research, 265, 218-231.

Kirkland, C. L., Spaggiari, C. V., Pawley, M. J., Wingate, M.T D., Smithies, R. H., Tyler, I. M., Howard, H. M., Belousova, E. A., \& Poujol, M. (2011). On the edge: U-Pb, Lu-Hf, and Sm-Nd data suggests reworking of the Yilgarn craton margin during formation of the Albany-Fraser Orogen. Precambrian Research, 187, 223-247.

Ksienzyk, A. K., \& Jacobs, J. (2015). Western Australia-Kalahari (WAlahari) connection in Rodinia: Not supported by U/Pb detrital zircon data from the Maud Belt (East Antarctica) and the Northampton Complex (Western Australia). Precambrian Research, 259, 207-221.

Ksienzyk, A. K., Jacobs, J., Boger, S. D., Kosler, J., Sircombe, K. N., \& Whitehouse, M. J. (2012). U-Pb ages of metamorphic monazite and detrital zircon from the Northampton Complex: evidence of two orogenic cycles in Western Australia. Precambrian Research, 198-199, 3750 .

Lewis, C. J., Taylor, D. H., Cayley, R. A., Schofield, A., \& Skladzien, P. B. (2015). New SHRIMP U-Pb zircon ages from the Grampians-Stavely Zone, Victoria: July 2013-July 2014. Geoscience Australia Record 2015/26. Canberra ACT: Geoscience Australia.

Liu, X., Jahn, B., Zhao, Y., Li, M., Li, H., \& Liu, X. (2006). Late Pan-African granitoids from the Grove Mountains, East Antarctica: Age, origin and tectonic implications. Precambrian Research, 145, 131-154.

Liu, X., Zhao, H., \& Hu, J. (2013). The c. 1000-900 Ma and c. 550-500 Ma tectonothermal events in the Prince Charles Mountains-Prydz Bay region, east Antarctica, and their relations to supercontinent evolution. In S. L. Harley, I. C. W. Fitzsimons \& Y. Zhao (Eds.) Antarctica and Supercontinent Evolution (pp. 95-112). Geological Society, London, Special Publications 383. London UK: Geological Society, London.

Lyons, P., Raymond, O. L., \& Duggan, M. B. (Compiling editors) (2000). Forbes 1:250 000 Geological Sheet SI55-7, 2nd edition, Explanatory notes. AGSO Record 2000/20. Canberra ACT: AGSO.

McCulloch, M. T. (1987). Sm-Nd isotopic constraints on the evolution of Precambrian crust in the Australian continent. In A. Kröner (Ed.) Proterozoic Lithospheric Evolution (pp. 115130). Washington, DC: American Geophysical Union, Geodynamics Series, 17.

McCulloch, M. T., \& Chappell, B. W. (1982). Nd isotopic characteristics of S- and I-type granites. Earth and Planetary Science Letters, 58, 51-64.

McCulloch, M. T., \& Woodhead, J. D. (1993). Lead isotopic evidence for deep crustal-scale fluid transport during granite petrogenesis. Geochimica et Cosmochimica Acta, 57, 659-674.

Maboko, M. A. H., McDougall, I., Zeitler, P. K., \& Williams, I. S. (1992). Geochronological evidence for 530-550 Ma juxtaposition of two Proterozoic metamorphic terranes in the Musgrave Ranges, central Australia. Australian Journal of Earth Sciences, 39, 457-471.

Maidment, D. W., Williams, I. S., \& Hand, M. (2007). Testing long-term patterns of basin sedimentation by detrital zircon geochronology, Centralian Superbasin, Australia. Basin Research, 19, 335-360. 
Meert, J. G. (2003). A synopsis of events related to the assembly of eastern Gondwana. Tectonophysics, 362, 1-40.

Meffre, S., Scott, R. J., Glen, R., \& Squire, R. (2007). Re-evaluation of contact relationships between Ordovician volcanic belts and the quartz-rich turbidites of the Lachlan Orogen. Australian Journal of Earth Sciences, 54, 363-383.

Mikhalsky, E. V., Belyatsky, B. V., Presnyakov, S. L., Skublov, S. G., Kovach, V. P., Rodionov, N. V., Antonov, A. V., Saltykova, A. K., \& Sergeev, S. A. (2015). The geological composition of the hidden Wilhelm II Land in East Antarctica: SHRIMP zircon, Nd isotopic and geochemical studies with implications for Proterozoic supercontinent reconstructions. Precambrian Research, 258, 171-185.

Mikhalsky, E. V., Henjes-Kunst, F., Belyatsky, B. V., Roland, N. W., \& Sergeev, S. A. (2010). New $\mathrm{Sm}-\mathrm{Nd}, \mathrm{Rb}-\mathrm{Sr}, \mathrm{U}-\mathrm{Pb}$ and $\mathrm{Hf}$ isotope systematics for the southern Prince Charles Mountains (East Antarctica) and its tectonic implications. Precambrian Research, 182, 101-123.

Mikhalsky, E. V., Sheraton, J. W., Kudriavtsev, I. V., Sergeev, S. A., Kovach, V. P., Kamenev, I. A., \& Laiba, A. A. (2013). The Mesoproterozoic Rayner Province in the Lambert Glacier area: its age, origin, isotopic structure and implications for Australia-Antarctica correlations. In S. L. Harley, I. C. W. Fitzsimons \& Y. Zhao (Eds.) Antarctica and Supercontinent Evolution (pp. 35-57). Geological Society, London, Special Publications 383. London UK: Geological Society, London.

Millar, I. L., \& Storey, B. C. (1995). Early Paleozoic rather than Neoproterozoic volcanism and rifting within the Transantarctic Mountains. Journal of the Geological Society of London, $152,417-420$.

Möller, A., Post, N. J. \& Hensen, B. J. (2002). Crustal residence history and garnet Sm-Nd ages of highgrade metamorphic rocks from the Windmill Islands area, East Antarctica. International Journal of Earth Sciences, 91, 993-1004.

Moyes, A. B., Groenewald, P. B., \& Brown, R. W. (1993). Isotopic constraints on the age and origin of the Brattskarvet intrusive suite, Dronning Maud Land, Antarctica. Chemical Geology, 106, 453-466.

Myers, J. S., Shaw, R. D., \& Tyler, I. M. (1996). Tectonic evolution of Proterozoic Australia. Tectonics, 15, 1431-1446.

Myrow, P. M., Pope, M. C., Goodge, J. W., Fischer, W., \& Palmer, A. R. (2002). Depositional history of pre-Devonian strata and timing of Ross orogenic tectonism in the central Transantarctic Mountains, Antarctica. Geological Society of America Bulletin, 114, 1070-1088.

Nebel-Jacobsen, Y., Münker, C., Nebel, O., \& Mezger, K. (2011). Precambrian sources of Early Paleozoic SE Gondwana sediments as deduced from combined $\mathrm{Lu}-\mathrm{Hf}$ and $\mathrm{U}-\mathrm{Pb}$ systematics of detrital zircons, Takaka and Buller terrane, South Island, New Zealand. Gondwana Research, 20, 427-442.

Offler, R., \& Fergusson, C. L. (2016). Proto-Pacific-margin source for the Ordovician turbidite submarine fan, Lachlan Orogen, southeast Australia: Geochemical constraints. Sedimentary Geology, 334, 53-65.

Osanai, Y., Nogi, Y., Baba, S., Nakano, N., Adachi, T., Hokada, T., Toyoshima, T., Owada, M., SatishKumar, M., Kamei, A., \& Kitano, I. (2013). Geologic evolution of the Sør Rondane Mountains, East Antarctica: collision tectonics proposed basedon metamorphic processes and magnetic anomalies. Precambrian Research, 234, 8-29. 
Packham, G. H. (1969). Tectonics and sedimentation. In G. H. Packham (Ed.) Geology of New South Wales. Journal of the Geological Society of Australia, 16, 216-226.

Page, R. W., Stevens, B. P. J., \& Gibson, G. M. (2005). Geochronology of the sequence hosting the Broken Hill Pb-Zn-Ag orebody, Australia. Economic Geology, 100, 633-661.

Pahl, J. K., \& Sikorska, M. (2004). Cathodoluminescence study of carbonate cements in the Upper Cambrian conglomerates from the Wonominta Block, northwestern New South Wales. Australian Journal of Earth Sciences, 51, 247-259.

Paulsen, T. S., Encarnación, J., Grunow, A. M., Valencia, V. A., Pecha, M., Layer, P. W., \& Rasoazanamparany, C. (2013). Age and significance of 'outboard' high-grade metamorphics and intrusives of the Ross orogen, Antarctica. Gondwana Research, 24, 349358.

Paulsen, T. S., Encarnación, J., Grunow, A. M., Valencia, V. A., Layer, P. W., Pecha, M., Stump, E., Roeske, S., Thao, S., \& Rasoazanamparany, C. (2015). Detrital mineral ages from the Ross Supergroup, Antarctica: Implications for the Queen Maud terrane and outboard sediment provenance on the Gondwana margin. Gondwana Research, 27, 377-391.

Peng, S., Babcock, L. E., \& Cooper, R. A. (2012). Chapter 19. The Cambrian Period. In F. M. Gradstein, J. G. Ogg, M. D. Schmitz, \& G. M. Ogg (Eds.) The Geologic Time Scale 2012 (pp. 437-488). Amsterdam: Elsevier.

Percival, I. G. (1999). Microfossiliferous cherts from the Forbes 1:250 000 map sheet, Central New South Wales. Unpublished palaeontological report, 99/02. Sydney NSW: Geological Survey of New South Wales GS1999/513.

Percival, I. G. (2011). Biotic characteristics of Ordovician deep-water cherts from Eastern Australia. Palaeogeogeography, Palaeoclimatology, Palaeoecology, 367-368, 63-72.

Percival, I. G. (2012). Appendix. In G. R. Burton, S. J. Trigg \& L. M. Campbell Sussex and Byrock 1:100 000 geological sheets, 1st edition, Explanatory Notes. Maitland, NSW: Geological Survey of New South Wales.

Percival, I. G., \& Glen, R. A. (2007). Ordovician to earliest Silurian history of the Macquarie Arc, Lachlan Orogen, New South Wales. Australian Journal of Earth Sciences, 54, 143-165.

Percival, I. G., Quinn, C. D., \& Glen, R. A. (2011). Review of Cambrian and Ordovician stratigraphy in New South Wales. Quarterly Notes of the Geological Survey of New South Wales, 137, 139.

Pogson, D. J., \& Felton, E. A. (1978). Reappraisal of Geology, Cobar-Canbelego-Mineral Hill Region, Central New South Wales. Quarterly Notes of the Geological Survey of New South Wales, 33, 1-14.

Preiss, W. V. (2000). The Adelaide Geosyncline of South Australia and its significance in Neoproterozoic continental reconstruction. Precambrian Research, 100, 21-63.

Pullen, A., Ibanez-Mejia, M., Gehrels, G. E., Ibanez-Mejia, J. C., \& Pecha, M. (2014). What happens when $\mathrm{n}=1000$ ? Creating large geochronological datasets with LA-ICP-MS for geologic investigations. Journal of Analytical Atomic Spectrometry, 29, 971-980.

Quinn, C. D., Percival, I. G., Glen, R. A., \& Xiao, W.-J. (2014). Ordovician marginal basin evolution near the palaeo-Pacific east Gondwana margin, Australia. Journal of the Geological Society, London, 171, 723-7

Reed, A. R. (2001). Pre-Tabberabberan deformation in eastern Tasmania: a southern extension of the Benambran Orogeny. Australian Journal of Earth Sciences, 48, 785-796.

Read, S. E. (2010). Koettlitz Glacier Alkaline Province : Late Neoproterozoic extensional magmatism in southern Victoria Land, Antarctica Ph.D. thesis, Department of Geology. Dunedin NZ: University of Otago. Dunedin, New Zealand (unpublished, with abstract available online). 
Read, S. E., Cooper, A. F., \& Walker, N. W. (2002). Geochemistry and U-Pb geochronology of the Neoproterozoic-Cambrian Koettlitz Glacier alkaline province, Royal Society Range, Transantarctic Mountains, Antarctica. In J. A. Gamble, D. N. B. Skinner, \& S. Henrys (Eds.) Antarctica at the close of a millennium (pp. 143-151). Royal Society of New Zealand Bulletin, 35.

Read, S. E. (2010). Koettlitz Glacier Alkaline Province : Late Neoproterozoic extensional magmatism in southern Victoria Land, Antarctica Ph.D. thesis, Department of Geology. Dunedin NZ: University of Otago (unpublished, with abstract available online).

Rocchi, S., Bracciali, L., Di Vincenzo, G., Gemelli, M., \& Ghezzo, C. (2011). Arc accretion to the early Paleozoic Antarctic margin of Gondwana in Victoria Land. Gondwana Research, 19, 594607.

Rocchi, S., DI Vincenzo, G., \& Ghezzo, C. (2004). The Terra Nova Intrusive Complex (Victoria Land, Antarctica). Terra Antarctica Reports, 10, 49 pp. + map ISBN 88-88395-07-5. Published by the Earth Science Section of the Museo Nazionale dell'Antartide.

Rocchi, S., Tonarini, S., Armienti, P., Innocenti, F., \& Manetti, P. (1998). Geochemical and isotopic structure of the early Palaeozoic margin of Gondwana in northern Victoria Land, Antarctica. Tectonophysics, 284, 261-281.

Rowell, A. J., Rees, M. N., Duebendorfer, E. M., Wallin, E. T., Van Schmus, W. R., \& Smith, E. I. (1993). An active Neoproterozoic margin - evidence from the Skelton Glacier area, Transantarctic Mountains. Journal of the Geological Society, London, 150, 677-682.

Rowell, A. J., Van Schmus, W. R., Storey, B. C., Fetter, A. H., \& Evans, K. R. (2001). Latest Neoproterozoic to Mid-Cambrian age for the main deformation phases of the Transantarctic Mountains: New stratigraphic and isotopic constraints from the Pensacola Mountains, Antarctica. Journal of the Geological Society of London, 158, 295-308.

Scherer, E., Munker, C., \& Mezger, K. (2001). Calibration of the Lutetium-Hafnium clock. Science, 293, 683-687.

Schmädicke, E., Will, T. M., \& Mezger, K. (2015). Garnet pyroxenite from the Shackleton Range, Antarctica: Intrusion of plume-derived picritic melts in the continental lithosphere during Rodinia breakup? Lithos, 238, 185-206.

Scott, M. M., \& Sherwin, L. (2000). Condobolin First Edition (1:100 000 geological map 8331). Canberra ACT: Australian Geological Survey Organisation/NSW Department of Mineral Resources.

Scrimgeour, I., \& Close, D. (1999). Regional high-pressure metamorphism during intracratonic deformation; the Petermann Orogeny, central Australia. Journal of Metamorphic Geology, 17, 557-572.Sheraton, J. W., Black, L. P. \& Tindle, A. G. (1992). Petrogenesis of plutonic rocks in a Proterozoic granulite-facies terrane - the Bunger Hills, East Antarctica. Chemical Geology, 97, 163-198.

Shiraishi, K., Dunkley, D. J., Hokada, T., Fanning, C.M., Kagami, H., \& Hamamoto, T. (2008). Geochronological constraints on the Late Proterozoic to Cambrian crustal evolution of eastern Dronning Maud Land, East Antarctica: a synthesis of SHRIMP U-Pb age and $\mathrm{Nd}$ model age data. In M. Satish-Kumar, Y. Motoyoshi, Y. Osanai, Y. Hiroi \& K. Shiraishi (Eds.) Geodynamic Evolution of East Antarctica: A Key to the East-West Gondwana Connection (pp. 21-67). Geological Society, London, Special Publication 308. London UK: Geological Society, London.

Smithies, R. H., Howard, H. M., Evins, P. M., Kirkland, C. L., Kelsey, D. E., Hand, M., Wingate, M. T. D., Collins, A. S., \& Belousova, E. (2011). High-temperature granite magmatism, crust- 
mantle interaction and the Mesoproterozoic intracontinental evolution of the Musgrave Province, Central Australia. Journal of Petrology, 52, 931-958.

Smithies, R. H., Kirkland, C. L., Korhonen, F. J., Aitken, A. R. A., Howard, H. M., Maier, W. D., Wingate, M. T. D., Quentin de Gromar, R., \& Gessner, K. (2014). The Mesoproterozoic thermal evolution of the Musgrave Province in central Australia - Plume vs. the geological record. Gondwana Research, 27, 1419-1429.

Smithies, R. H., Howard, H. M., Evins, P. M., Kirkland, C. L., Kelsey, D. E., Hand, M., Wingate, M. T. D., Collins, A. S., \& Belousova, E. (2011). High-temperature granite magmatism, crustmantle interaction and the Mesoproterozoic intracontinental evolution of the Musgrave Province, Central Australia. Journal of Petrology, 52, 931-958.

Spaggiari, C. V., Gray, D. R., \& Foster, D. A. (2003). Tethyan- and Cordilleran-type ophiolites of eastern Australia: implications for the evolution of the Tasmanides. In Y. Dilek \& P. T. Robinson (Eds.) Ophiolites in Earth History (pp. 517-539). Special Publication 218. London UK: Geological Society London.

Squire, R. J., Campbell, I. H., Allen, C. M., \& Wilson, C. J. L. (2006c). Did the Transgondwanan Supermountain trigger the explosive radiation of animals on Earth? Earth and Planetary Science Letters, 250, 116-133.

Squire, R. J., Stewart, I. R., \& Zang, W. L. (2006a). Acritarchs in polydeformed and highly altered Cambrian rocks in western Victoria. Australian Journal of Earth Sciences, 53, 697-705.

Squire, R. J., Wilson, C. J. L., Dugdale, L. J., \& Jupp, B. (2006b). Cambrian backarc-basin basalt in western Victoria related to evolution of a continent-dipping subduction zone. Australian Journal of Earth Sciences, 53, 707-719.

Stewart, I. R. (1988). Conodonts. In R. A. F. Cas \& A. H. M. VandenBerg, Ordovician. In J. G. Douglas \& J. A. Ferguson (Eds.) Geology of Victoria (pp. 79-81). Melbourne Vic: Geological Society of Australia, Victorian Division.

Stewart, I. R., \& Glen, R. A. (1986). An Ordovician age for part of the Girilambone group at Yanda Creek, east of Cobar. Quarterly Notes, Geological Survey of New South Wales, 64, 23-25.

Stump, E. (1995). The Ross Orogen of the Transantarctic Mountains. Cambridge: Cambridge University Press, 284 pp.

Stump, E., Edgerton, D. G., \& Korsch, R. J. (2002). Geological relationships at Cotton Plateau, Nimrod Glacier area, bearing on the tectonic development of the Ross orogen, Transantarctic Mountains, Antarctica. Terra Antarctica, 9, 3-1

Stump, E., Gehrels, G., Talarico, F., \& Carosi, R. (2007). Constraints from detrital zircon geochronology on the early deformation of the Ross orogen, Transantarctic Mountains, Antarctica. In A. K. Cooper \& C. R. Raymond (Eds.) Antarctica: A Keystone in a Changing World Antarctica: Abstract 166. Proceedings of the 10th ISAES. US Geological Survey Open File Report 2007-1047. https://pubs.usgs.gov/of/2007/1047

Stump, E., Gootee, B. F., Talarico, F., Van Schmus, W. R., Brand, P. K., Foland, K. A., \& Fanning, C. M. (2004). Correlation of Byrd and Selbourne Groups, with implications for the Byrd Glacier discontinuity. New Zealand Journal of Geology and Geophysics, 47, 157-171.

Thomas, O. D., \& Scott, M. M. 2012. Willigam Sandstone Member. In O. D. Thomas \& D. J. Pogson (compilers). Goulburn 1:250 000 Geological Sheet SH/55-12, 2nd edition, Explanatory Notes. Geological Survey of New South Wales, Maitland, NSW. pp. 300-303 (DVD).

Tonarini, S., \& Rocchi, S. (1994). Geochronology of Cambro-Ordovician intrusives in northern Victoria Land: a review. Terra Antartica, 1, 46-50. 
Tickell, S. J. (1989). Dookie 1:100 000 map Geological Report. Melbourne Vic: Geological Survey of Victoria Report 87, $70 \mathrm{pp}$.

Turner, S. P., Kelley, S. P., Vandenberg, A. H. M., Foden, J. D., Sandiford, M., \& Flottmann, T. (1996). Source of the Lachlan fold belt flysch linked to convective removal of the lithospheric mantle and rapid exhumation of the Delamerian-Ross fold belt. Geology, 24, 941-944.

Van Schmus, W. R., McKenna, L. W., Gonzales, D. A., Fetter, A. H., \& Rowell, A. J. (1997). U-Pb geochronology of parts of the Pensacola, Thiel, and Queen Maud Mountains, Antarctica. In C. A. Ricci (Ed.) The Antarctic region: geological evolution and processes (pp. 187-200). Sienna Italy: Terra Antartica.

VandenBerg, A. H. M., Cayley, R. A., Willman, C. E., Morand, V. J., Seymon, A. R., Osborne, C. R, Taylor, D. H., Haydon, S. J., McLean, M., Quinn, C., Jackson, P. (2006). Walhalla-Woods Point-Tallangalook special map area geological report, 127, 448 pp. Melbourne Vic: Geological Survey of Victoria

VandenBerg, A. H. M., Willman, C. E., Maher, S., Simons, B. A., Cayley, R. A., Taylor, D. H., Morand, V. J., Moore, D. H., \& Radojkovic, A. (2000). The Tasman Fold Belt System in Victoria. Special Publication. Melbourne, Vic: Geological Survey of Victoria..

Veevers, J. J., \& Saeed, A. (2011). Age and composition of Antarctic bedrock reflected by detrital zircons, erratics, and recycled microfossils in the Prydz Bay-Wilkes Land-Ross Sea-Marie Byrd Land sector $\left(70^{\circ}-240^{\circ} \mathrm{E}\right)$. Gondwana Research, 20, 710-738.

Veevers, J. J., \& Saeed, A. (2013). Age and composition of Antarctic sub-glacial bedrock reflected by detrital zircons, erratics, and recycled microfossils in the Ellsworth Land-Antarctic Peninsula-Weddell Sea-Dronning Maud Land sector $\left(240^{\circ} \mathrm{E}-0^{\circ}-015^{\circ} \mathrm{E}\right)$. Gondwana Research, 23, 296-332.

Veevers, J. J., Belousova, E. A., Saeed, A., Sircombe, K., Cooper, A. F., \& Read, S. E. (2006). PanGondwanaland detrital zircons from Australia analysed for Hf-isotopes and trace elements reflect an ice-covered Antarctic provenance of 700-500 Ma age, TDM of 2.0-1.0 Ga, and alkaline affinity. Earth-Science Reviews, 76, 136-174.

Vervoort, J. D., Patchett, J. D., Blichert-Toft, J., \& Albarède, F. (1999). Relationships between Lu$\mathrm{Hf}$ and $\mathrm{Sm}-\mathrm{Nd}$ isotopic systems in the global sedimentary system. Earth and Planetary Science Letters, 168, 79-99.

Wade, B. P., Barovich, K. M., Hand, M., Scrimgeour, I. R., \& Close, D. F. (2006). Evidence for early Mesoproterozoic arc magmatism in the Musgrave Block, Central Australia: Implications for Proterozoic crustal growth and tectonic reconstructions of Australia. The Journal of Geology, 114, 43-63.

Wade, B. P., Hand, M., \& Barovich, K. M. (2005). Nd isotopic and geochemical constraints on provenance of sedimentary rocks in the eastern Officer Basin, Australia: implications for the duration of the intracratonic Petermann Orogeny. Journal of the Geological Society of London, 162, 513-530.

Wareham, C. D., Stump, E., Storey, B. C., Millar, I. L., \& Riley, T. R. (2001). Petrogenesis of the Cambrian Liv Group, a bimodal volcanic rock suite from the Ross orogen, Transantarctic Mountains, Geological Society of America Bulletin, 113, 360-372.

Webby, B. D. (1978). History of the Ordovician continental platform shelf margin of Australia. Journal of the Geological Society of Australia, 25, 41-63.

White, L. T., Gibson, G. M., \& Lister, G. S. (2013). A reassessment of paleogeographic reconstructions of eastern Gondwana: Bringing geology back into the equation. Gondwana Research, 24, 984-998. 
Wiedenbeck, M., Alle, P., Corfu, F., Griffin, W. L., Meier, M., Oberli, F., Von Quadt, A., Roddick, J. C., \& Spiegel, W. (1995). Three natural zircon standards for U-Th-Pb, Lu-Hf trace element and REE analyses. Geostandards Newsletter, 19, 1-24.

Wilde, S. A. (1999). Evolution of the western margin of Australia during Rodinian and Gondwanan supercontinent cycles. Gondwana Research, 2, 481-499.

Will, T. M., Zeh, A., Gerdes, A., Frimmel, H. E., \& Millar, I. L. (2009). Palaeoproterozoic to Palaeozoic magmatic and metamorphic events in the Shackleton Range, East Antarctica: constraints from zircon and monazite dating, and implications for the amalgamation of Gondwana. Precambrian Research, 172, 25-45.

Williams, I. S., Goodge, J., Myrow, P., Burke, K. \& Kraus, J. 2002. Large scale sediment dispersal associated with the late Neoproterozoic assembly of Gondwana. Abstracts of the Geological Society of Australia, 67, 234.

Wyborn, L., Chappell, B. W., \& Wyborn, D. (1979). The Lachlan Fold Belt-early Palaeozoic links with Antarctica (abstract). Journal of the Geological Society of Australia, 26, 277.

Wysoczanski, R. J., \& Allibone, A. H. (2004). Age, correlation, and provenance of the Neoproterozoic Skelton Group, Antarctica: Grenville age detritus on the margin of East Antarctica. The Journal of Geology, 112, 401-416.

Yakymchuk, C., Brown, C. R., Brown, M., Siddoway, C. S., Fanning, C. M., \& Korhonen, F. J. (2015). Paleozoic evolution of western Marie Byrd Land, Antarctica, Geological Society of America Bulletin, 127 1464-1484.

Zhao, J. X., McCulloch, M. T., \& Bennett, V. C. (1992). Sm-Nd and U-Pb zircon isotopic constraints on the provenance of sediments from the Amadeus Basin, central Australia: evidence for REE fractionation. Geochimica et Cosmochimica Acta, 56, 921-940.

Zhen, Y.-Y., Percival, I. G., \& Webby, B. D. (2003). Early Ordovician conodonts from far western New South Wales, Australia. Records of the Australian Museum, 55, 169-220.

\section{Figures and table captions}

Figure 1. Southern Tasmanides of eastern Australia. (a) Map, showing terrane and stratigraphic names and locations of samples. Abbreviations: Fault names: mf, Moyston Fault; af, Avoca Fault; hf, Heathcote Fault Zone; dz, Djerriwah Fault; gof, Governor Fault Zone; kf, Kancoona and Kiewa faults; bf, Bootheragandra Fault and extensions; if, Indi-Long Plain Fault; gf, Gilmore Fault Zone; tf, Tullamore Fault; ks, Kiandra-Narromine Structure; rf, Rookery Fault System; OF, Olepoloko Fault; Lesz, Louth-Eumarra Shear Zone. Ordovician units in the New England Orogen from Glen (2013), updated in Glen et al. (2016). Linkage occurs between lower part of Castlemaine Gp in Bowers Terrane and southwest corner of Melbourne Terrane. Cayley (2016, written comments) suggests that the Waratah Bay Terrane is an outcropping part of the Selwyn Block. (b) WNW-ESE-oriented time-space plot, showing lithologies, terrane names as well as sample locations by black dots. Both updated from Glen et al. (2009), with geology north of Bendigo Terrane based on Glen et al. (2016).

Figure 2 (a) Sandstone compositions. (a) Compositions of six samples of sandstone obtained by FEI using combination of a scanning electron microscopy plus X-ray spectroscopy to map and analyse individual grains. The mineral composition of selected sandstone samples was determined using the QEMSCAN technology system, invented by CSIRO and now owned by FEI. The system uses back-scattered electron imaging to map and locate individual grains. It then samples multiple points within each grain to produce an energy-dispersive X-ray 
spectrum that is analysed to give the chemical composition of the grain itself. The first two samples are from two of the samples from the Gnalta Shelf, Delamerian Orogen: Scropes Range Formation (sample 06/1E/1 shortened to 06E1) and Yandaminta Quartzite (sample labelled 06/05/5 collected adjacent to analysed sample 606). The remaining four samples are from Ordovician turbiditic sandstones analysed for this study, one from the Hermidale Terrane, two from the Albury-Bega Terrane west and one from the Albury-Bega Terrane east. (b) Photomicrograph of typical turbiditic sandstone showing framework grains of quartz, feldspar and muscovite (circled). Scale bar $0.5 \mathrm{~mm}$. Carol Simpson photographer. (c) Willigam Sandstone Member from Thomas and Scott (2012) showing poorly sorted matrix-rich sandstone (wacke) typical of the member. Scale bar $0.5 \mathrm{~mm}$. Photographer O.D. Thomas.

Figure 3. Cathode-luminescent/scanning electron microscope images of zircon grains showing shapes and ages.

Figure 4. Gnalta Shelf, Bilpa Conglomerate. U-Pb probability plot.

Figure 5. Gnalta Shelf, Scropes Range Formation. $\mathrm{U}-\mathrm{Pb}$ and $\varepsilon_{\mathrm{Hf}}$ data $(\mathrm{a}-\mathrm{m})$.

Figure 6. Gnalta Shelf, Yandaminta Quartzite. U-Pb and $\varepsilon_{\mathrm{Hf}}$ data (a-h).

Figure 7. Comparison plots of Gnalta Shelf samples (a-e).

Figure 8. Bendigo Terrane, Castlemaine Group. Ben2. U-Pb and $\varepsilon_{\mathrm{Hf}}$ data (a-l).

Figure 9. Bendigo Terrane, Castlemaine Group. Ben5. U-Pb and $\varepsilon_{\mathrm{Hf}}$ data $(\mathrm{a}-\mathrm{k})$.

Figure 10. Bendigo Terrane, Castlemaine Group. Cob1. U-Pb and $\varepsilon_{\mathrm{Hf}}$ data (a-l).

Figure 11. Comparison plots of Bendigo Terrane samples (a-f).

Figure 12. Hermidale Terrane, Girilambone Group. Murrawombie1. U-Pb data (a-e).

Figure 13. Hermidale Terrane, Girilambone Group. TrittonNE. U-Pb data (a-f).

Figure 14. Hermidale Terrane, Girilambone Group. Te2. U-Pb and $\varepsilon_{\mathrm{Hf}}$ data (a-m).

Figure 15. Hermidale Terrane, Girilambone Group. Oggyc1. U-Pb and $\varepsilon_{\mathrm{Hf}}$ data (a-l).

Figure 16. Comparison plots of Hermidale Terrane samples (a-e).

Figure 17 Albury-Wagga Terrane west. Wagga Group. Oww5. U-Pb and $\varepsilon_{\mathrm{Hf}}$ data (a-l).

Figure 18. Albury-Wagga Terrane west. Wagga Group. Oww3. U-Pb and $\varepsilon_{\mathrm{Hf}}$ data $(\mathrm{a}-\mathrm{j})$.

Figure 19. Comparison plots of Albury-Bega Terrane west samples (a-f).

Figure 20. Albury-Wagga Terrane east. Adaminaby Group. Mum1. U-Pb data (a-j).

Figure 21. Albury-Wagga Terrane east. Adaminaby Group. Bun8. U-Pb and $\varepsilon_{\mathrm{Hf}}$ data (a-k).

Figure 22. Albury-Wagga Terrane east. Adaminaby Group. Bun9. U-Pb and $\varepsilon_{\mathrm{Hf}}$ data $(\mathrm{a}-\mathrm{j})$.

Figure 23. Albury-Wagga Terrane east. Adaminaby Group. Bun4. U-Pb and $\varepsilon_{\mathrm{Hf}}$ data (a-l).

Figure 24. Comparison plots of Albury-Bega Terrane east samples (a-f).

Figure 25. Plots of youngest (475-530 Ma) zircon ages in all samples, showing source rock types

(after Belousova et al., 2002), $\varepsilon_{\mathrm{Hf}}$ values and age ranges of potential Cambrian and Ordovician sources in the Delamerian and Lachlan orogens. Right side of figure shows ${ }^{40} \mathrm{Ar}-{ }^{39} \mathrm{Ar}$ data from detrital muscovite grains in the literature. Firstly, Lachlan Orogen samples: Bam and Har from Turner et al. (1996). Bam from Lancefieldian part of Castlemaine Group, Bendigo Terrane; Har from a pre-Darriwilian part of Pinnak Sandstone (Adaminaby Group), Albury-Bega Terrane west. F from Foster, Gray, Kwak \& Bucher (1998): summary of detrital mica histogram from Stawell Zone and Bendigo Zone (Castlemaine Group, Bendigo Terrane). H26 from Fergusson et al. (2005): Girilambone Group (Hermidale Terrane). Younger ages off-scale are 474, 472, 471, 469, 446, 458 Ma. Mogo from Fergusson and Phillips (2001): Adaminaby Group (Albury-Bega Terrane east). Sources of age data in left hand column: 1. Foden et al. (2006). 2. Black et al. (1997). 3. Haines et al. (2009). 4. Black et al. (1997), Crawford and Berry (1992). 5. Cayley (2014), Lewis, Taylor, Cayley, Schofield \& Skladzien (2015). 6. Draper (2006), Greenfield et al. 
(2011). 7. Corbett and Vicary (2014). 8. Crawford et al. (1996), Squire, Stewart \& Zang (2006a). 9. Crawford and Keays (1987), Spaggiari, Gray \& Foster (2003), VandenBerg et al. (2006). 10. Stawell Volcanics, Squire, Wilson, Dugdale \& Jupp (2006b). 11. Edwards, Wohlt, Slater, Olshina \& Hutchinson (1998), P. Jell and I. Stewart cited in VandenBerg et al. (2000), Jell (2013), I. Williams cited in Spaggiari et al. (2003). 12. Crawford and Keays (1987), Tickell (1989), Spaggiari et al. (2003). Secondly, Ross Orogen, Antarctica samples, described in Table 6: USF, CBG, SRG DSG from upper Byrd Group of Goodge et al. (2004a); RAM2 upper Byrd Group (Paulsen et al., 2015); Berg, Rennick, Molar and Robertson Bay units -(HJ) from Henjes-Kunst (2003); (DIV) from Di Vincenzo, Grande and Rossetti (2014).

Figure 26. Comparison $\varepsilon_{\mathrm{Hf}} \mathrm{V}$ age plots of all samples.

Figure 27. U-Pb data of Ordovician turbidites showing percentages of different populations as pie charts.

Figure 28. Host magmas of detrital zircons based on zircon trace element geochemistry model of Belousova et al. (2002). (a) Panafrican zircons. (b) Grenvillian zircons (a-l).

Figure 29. (a) Comparison probability plots between 400 and 1600 Ma for late Middle Ordovician units only. (b) Comparison probability plots between 400 and 1600 Ma for Lower Ordovician units only. (c) Comparison probability plots between 400 and $1600 \mathrm{Ma}$ for all Lower and upper Middle Ordovician units. (d) Comparison probability plots between 400 and 700 Ma for all Lower and upper Middle Ordovician units.

Figure 30. Possible source regions of zircons in Ordovician turbidites of the Lachlan Orogen and shallow-water sandstones of the Koonenberry Belt in the Delamerian Orogen. Figure modified from Harley et al. (2013), with most abbreviations from that paper. Inferred source regions of Ordovician turbidites and distributary patterns discussed in text. G1, 2, 3 $=$ regions of Grenvillian activity. P1a, P1b, P2 = regions of Panafrican activity, all described in text. PD3 one possible extension of Pinjarra Orogen in East Antarctica after Fitzsimons (2003). Ross Orogen is dark grey region of East Antarctica that extends from Northern Victoria Land (NV) to Pensacola Mountains (PS). Dotted part marks regions of Granite Harbour Intrusives containing Grenvillian xenocrysts. Areas of no outcrop in Antarctica left blank apart from the outline of the Gamburtsev Subglacial Mountains (GSM), Vostok Subglacial Highlands (VSH) and East Antarctic Rift System. Abbreviations: AF, AlbanyFraser Orogen; AM, Amundsen Province (Marie Byrd Land); AP, Antarctic Peninsula; BH, Bunger Hills; BK, Bundelkhand Craton; BS, Bastar Craton; CB, Coompana Block; CD, central Dronning Maud Land; CG, Congo Craton; $\mathrm{CH}$, Chatham Rise; CITZ, Central Indian Tectonic Zone; CK, Choma-Kalomo Block; CL, Coats Land; CM, Campbell Plateau; CP, Cape Fold Belt; CPR, Capricorn Orogen; CT, Central Transantarctic Mountains; DG, Denman Glacier; DM, Damara Orogen; DO, Delamerian Orogen; DW, Dharwar Craton; EG, Eastern Ghats Belt; EWM, Ellsworth-Whitmore Mountains Block; FM, Falkland-Malvinas Plateau; G, Grunehogna Craton; GM, Grove Mountains; GSM, Gamburtsev Subglacial Mountains; GW, Gawler Craton; IR, Irumide Orogen; KH, Kalahari Craton; kob, Koonenberry Belt; KB, Kibaran Orogen; LB, Lurio Belt; LF, Lufilian Arc; LH, Lutzow-Holm Complex; LO, Lachlan Orogen; MD, Madagascar; MP, Musgrave Province; MR, Miller Range; MY, Mirny; MZ, Mozambique Orogen; N, Napier Complex; NA, North Australian Craton; NEO, New England Orogen; NH, Northampton Complex; NN, Namaqua-Natal Orogen; NPC, northern Prince Charles Mountains; NV, Northern Victoria Land terranes (Wilson, Bowers and Robertson Bay terranes); NZ, New Zealand; PAT, Patagonia; PB, Prydz Bay; PJ, Pinjarra Orogen; PL, Pilbara Craton; PM, Petermann Orogen; PS Pensacola Mountains; PT, Paterson Orogen; QM Queen Maud Mountains; RG, Rauer Group; RS, Ross Province (Marie Byrd Land); RY, 
Rayner Complex; SB, Selwyn Block; SG, Southern Granulite Terrane; SI, Singhbhum Craton; SK, Shackleton Range; SP, present-day South Pole (with ticks indicating 00, 90E, 180 and 90W lines of longitude); SPC, Southern Prince Charles Mountains; SR, Sør Rondane Mountains; STR, South Tasman Rise; SV Southern Victoria Land; T, Tasmania; TA, Terre Adelie; THO, Thomson Orogen; TIB, Thurston Island Block; TM Thiel Mountains; TOAST, Tonian Oceanic Arc Super Terrane (Jacobs et al., 2015); TZ Tanzania Craton; VH, Vestfold Hills; VS subglacial source inferred by Veevers and Saeed (2013); VSH, Vostok Subglacial Highlands; WD, western Dronning Maud Land; WI, Windmill Islands; YG, Yilgarn Craton; ZM, Zambezi Orogen.

Figure 31. Ages of potential source rocks in orogenic belt, terranes and regions in Australia and East Antarctica compared with probability plots of Ordovician turbidites (400-1600 Ma) shown in Figure 29c3. Two sizes of xenocrystic zircon diagonal crosses reflect relative importance of population.

Figure 32. Comparison of $\varepsilon_{\mathrm{Hf}}$ and $\mathrm{T}_{\mathrm{DM}}(\mathrm{c})$ data from Ordovician turbidites with $\varepsilon_{\mathrm{Hf}}$ and model age - $\mathrm{T}_{\mathrm{DM}}$ (c) data - of possible source units in orogenic belt, terranes and regions in Australia and East Antarctica. $\varepsilon_{\mathrm{Hf}}$ values lie to left of double vertical line and model ages (Ga) to right. $\varepsilon_{\mathrm{Hf}}$ data in many cases calculated from $\varepsilon_{\mathrm{Nd}}(\mathrm{t})$ data as discussed in text. Data are from tables 3, 4, 5 or 6 . Note that in the second top row, ubg refers to upper Byrd Group sedimentary rocks from Goodge et al. (2012). Colour coding: pink, Panafrican population (s.l); black, Grenvillian (s.l) population; blue, population intermediate between the two as well 1720-1800 (s.l.). Note that model age data taken from literature has been rounded up or down since different authors have calculated this age in different ways. In the Delamerian granites (K) refers to data from Kemp et al. (2009), with other data from Foden et al. (2002).

Figure 33. Time-space plot of sedimentary sequences 2-4 developed along the length of the Ross Orogen from Northern Victoria Land to the Pensacola Mountains (locations in Figure 30). Data sources found in Table 6 and Supplementary Papers (Appendix 5), but mainly from: Northern Victoria Land, Adams et al. (2014), Estrada et al. (2106), including stratigraphic ages of units; Southern Victoria Land, Cooper et al. (2011), Stump et al. (2007); Central Transantarctic Mountains, Goodge et al. (2002, 2004a, b); Queen Maud Mountains, Paulsen et al. 2015); Pensacola Mountains, Curtis et al. (2004), Rowell et al. (2001), Goodge et al. (2004b).

Figure 34. Comparison of U-Pb zircon ages between sequence 4 Ross Orogen and Lachlan Ordovician turbidites. (a-c) are 400-1600 Ma probability plots, (e-g) are 400-3000 Ma probability plots. (a) upper Byrd Group, Central Transantarctic Mountains, from Goodge et al. (2002, 2004b); (b) 400-1600 Ma probability plots Liv Group, Queen Maud Mountains and upper Byrd Group Central Transantarctic Mountains, from Paulsen et al. (2015); (c) 400-1600 Ma probability plots of four representative Ordovician turbidites from the Hermidale Terrane and Albury-Bega Terrane Lachlan Orogen, two Early Ordovician (Oww5, Mum1) and two late Middle Ordovician (Oggyc1 and Bun4); (d) Data from one sample from the Liv Group above. See text for discussion; (e) 400-3000 Ma plots from upper Byrd Group from Goodge et al. (2002, 2004b). (f) 400-3000 Ma plots from Liv Group and upper Byrd Groups from Paulsen et al. (2015). (g) 400-3000 Ma plots of same Ordovician turbidites as in (c). (h) 400-700 Ma plots from upper Byrd Group from Goodge et al. (2002, 2004b). (i) 400-700 Ma plots from Liv Group and upper Byrd Groups from Paulsen et al. (2015). (j) 400-700 Ma probability plots of the four representative Ordovician turbidites.

Table 1. Ordovician terranes, descriptions and location. 
Table 2. Summary of $\mathrm{U}-\mathrm{Pb}, \varepsilon_{\mathrm{Hf}}$ and model age data.

Table 3. Possible source regions in Australia.

Table 4. Possible Antarctic source regions - I East Antarctic Shield.

Table 5. Possible Antarctic igneous sources - II Ross Orogen.

Table 6. Possible Antarctic sedimentary sources - III Ross Orogen.

\section{Supplementary papers}

A1. Additional information on zircon populations.

A2. Analytical procedures and methods.

A3. $\mathrm{T}_{\mathrm{DM}} \mathrm{C}$ graphic plots plots for different samples and clusters.

Figure A3-1. Scropes Range Formation.

Figure A3-2. Yandaminta Quartzite.

Figure A3-3. Ben2.

Figure A3-4. Ben5.

Figure A3-5. Cob1.

Figure A3-6. Te2.

Figure A3-7. Oggyc1.

Figure A3-8. Oww5.

Figure A3-9. Oww3.

Figure A3-10. Bun8.

Figure A3-11. Bun9.

Figure A3-12. Bun4.

Appendix 4. Terminology of zircon age populations.

Appendix 5. Supplements the text summary of published detrital zircon data from sedimentary sequences in the Ross Orogen.

Appendix 6. U-Pb data: Excel table.

Appendix 7. $\varepsilon_{\mathrm{Hf}}$ data: Excel table. 


\section{SHELF $\quad$ Australian Journal of Earth Sciences}

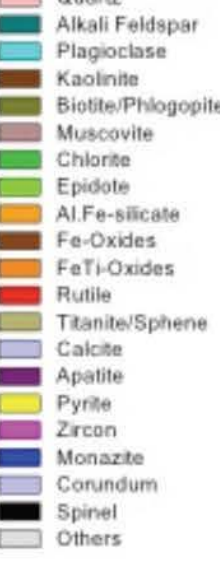

$106 / 05 / 5:-$

1

2

3

4

5 oggyc

6

7

8 8
100 ww5:
11 $12^{\text {Oww3:- }}$ 13

14 ALBURY-BEGA TERRANE (E)

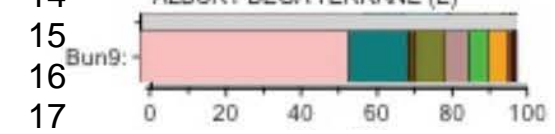

18

19

20

21

22

23

24

25

26

27

28

29

30

31

32

33

34

35

36

37

38

39

40

41

42 


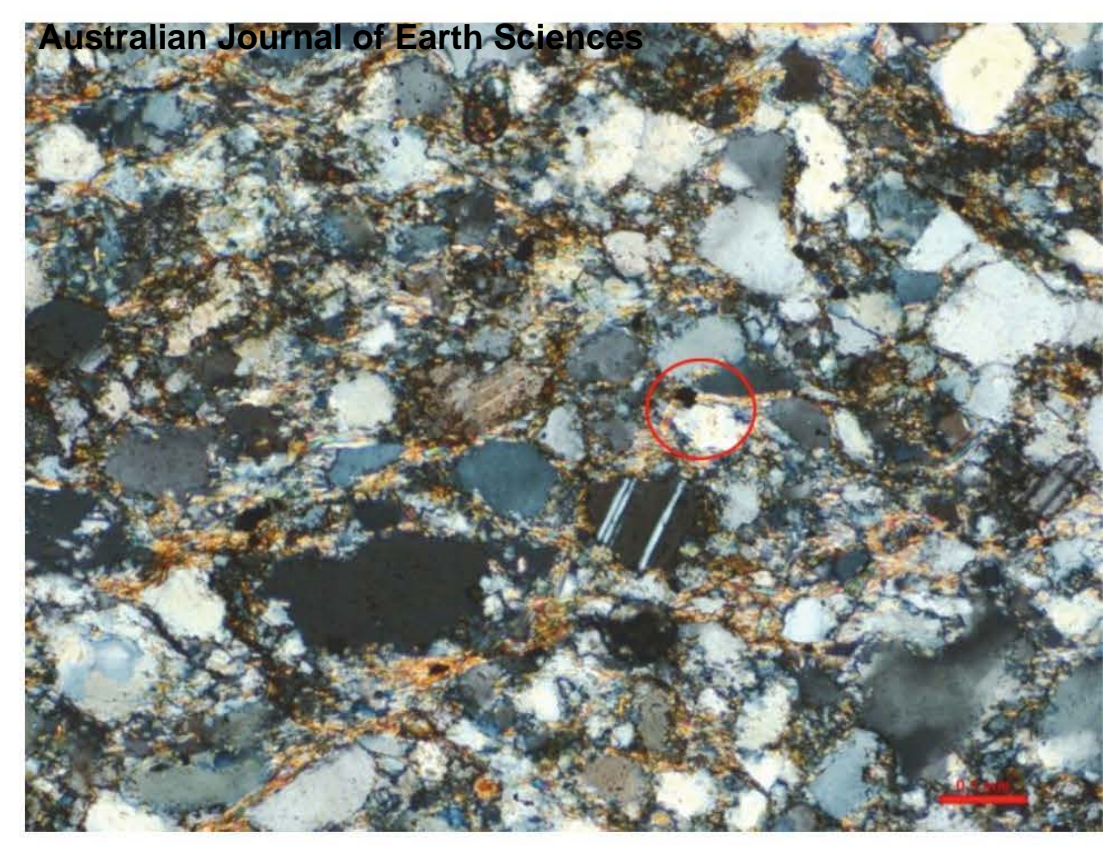




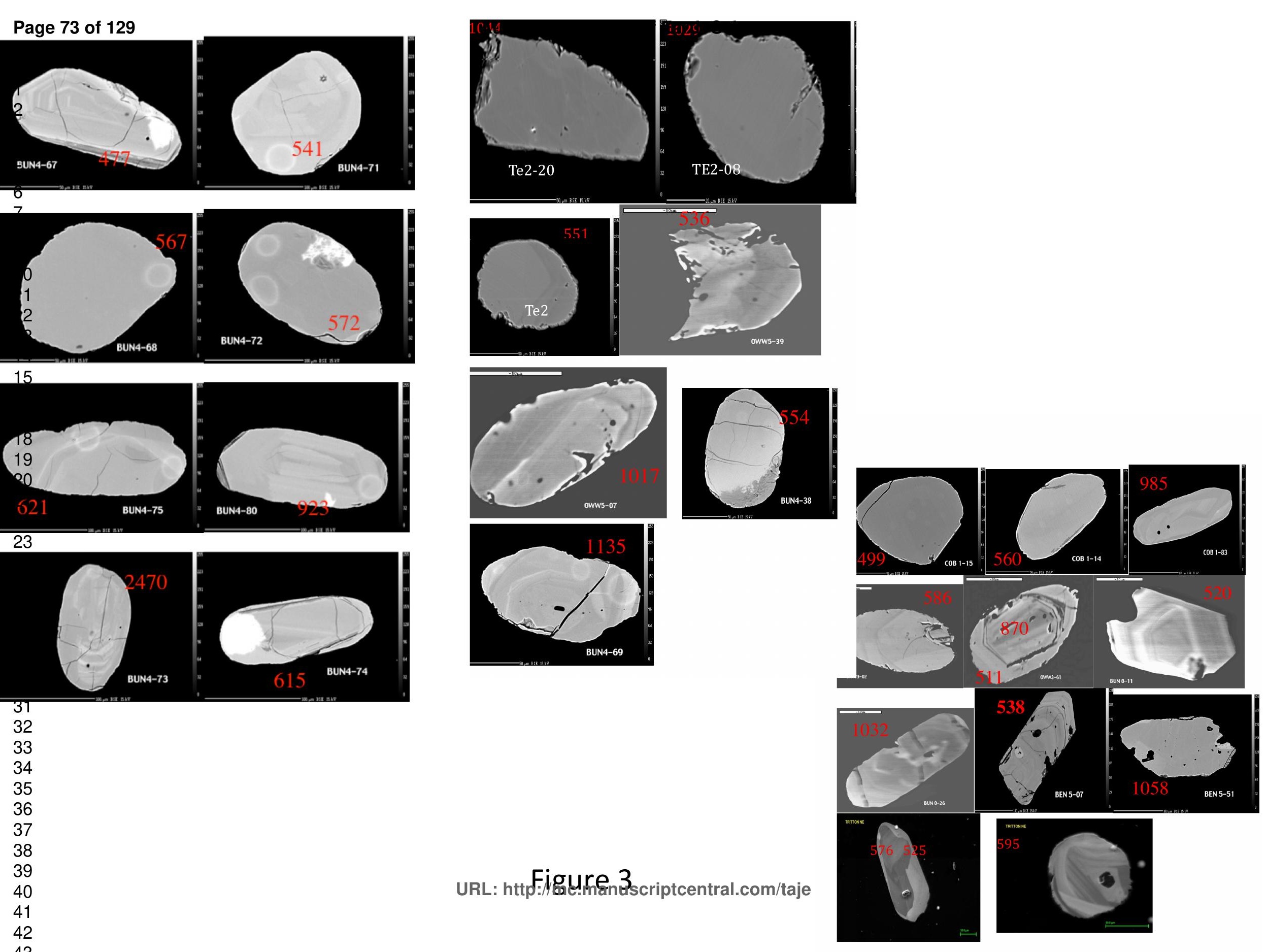


Australian Journal of Earth Sciences Page 74 of 129

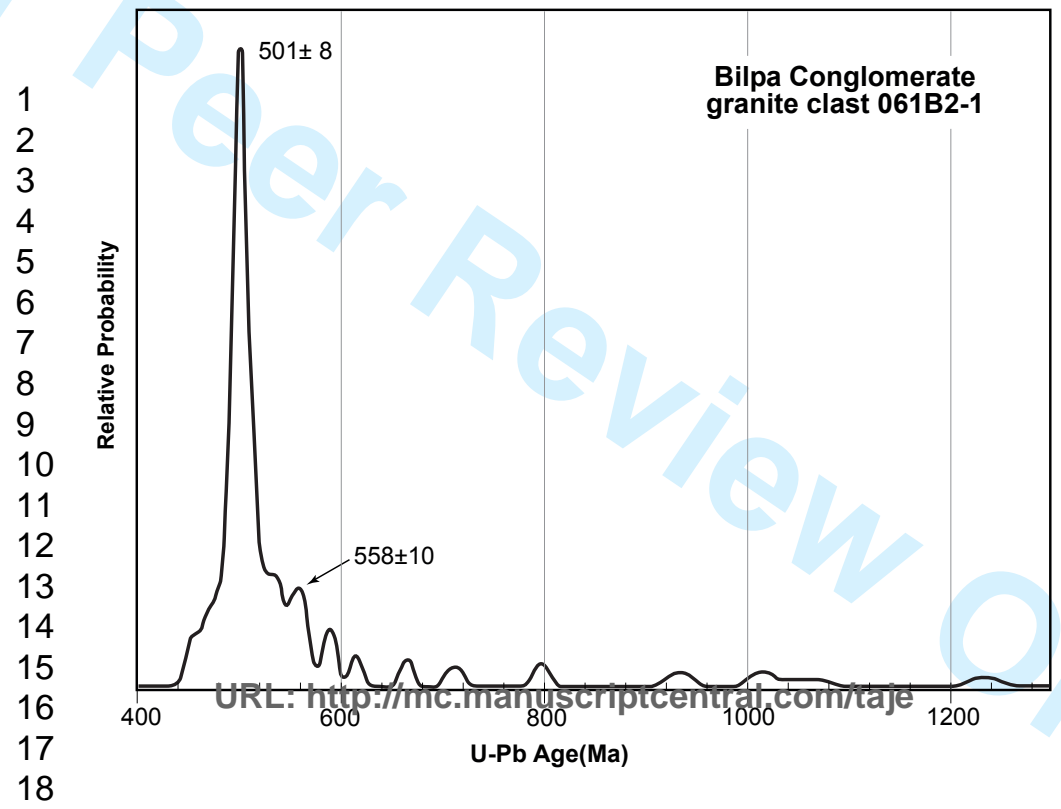





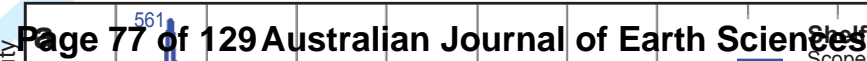

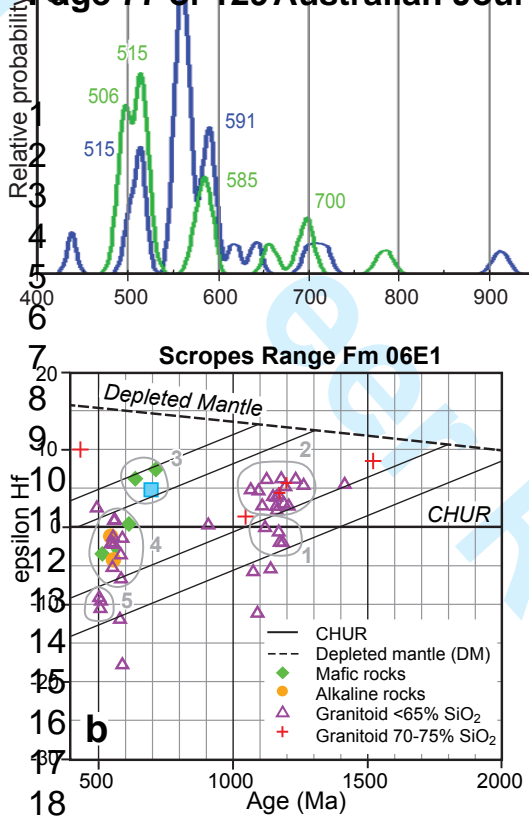

Scopes Range Fm 06E1 (?La)

—_ Yandaminta Qtzite 0606 (Be)
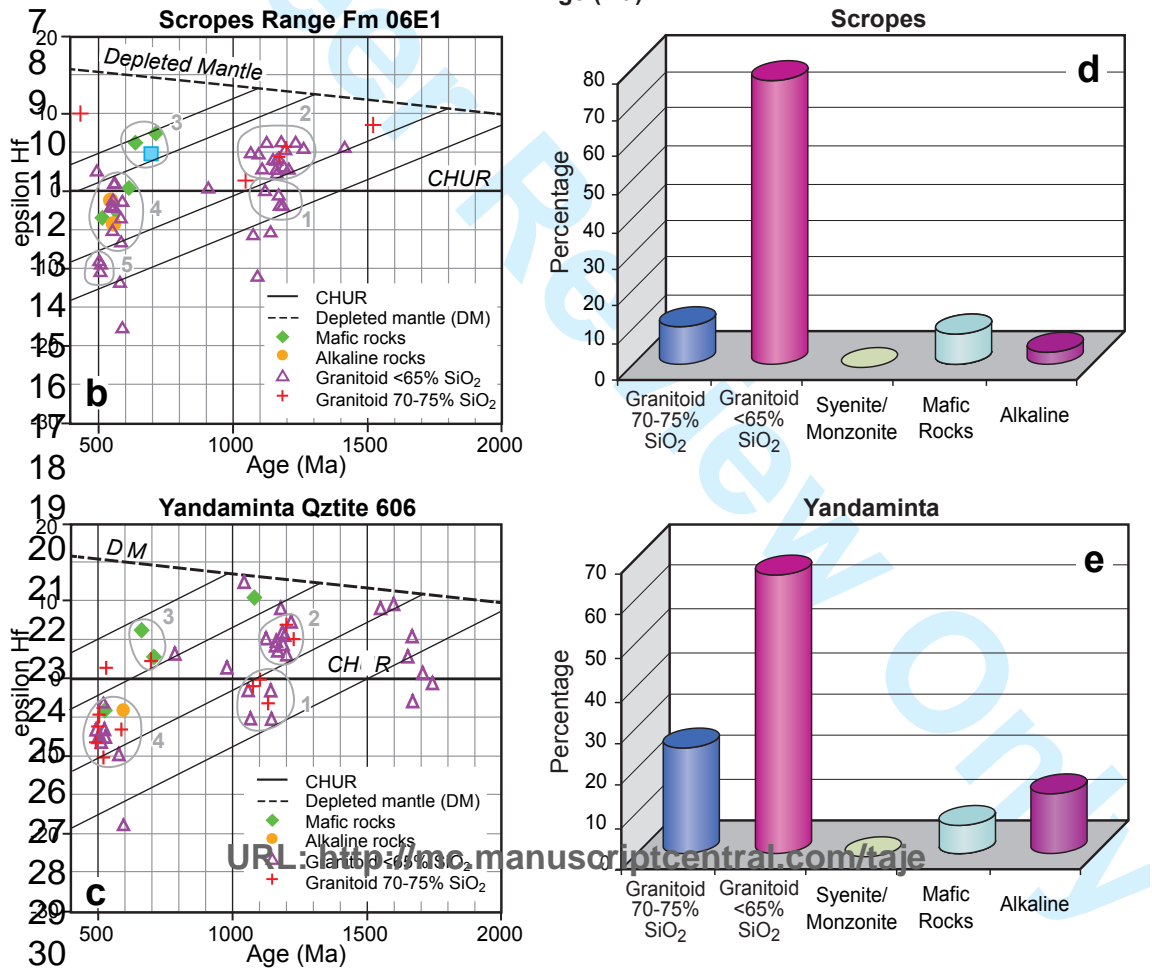


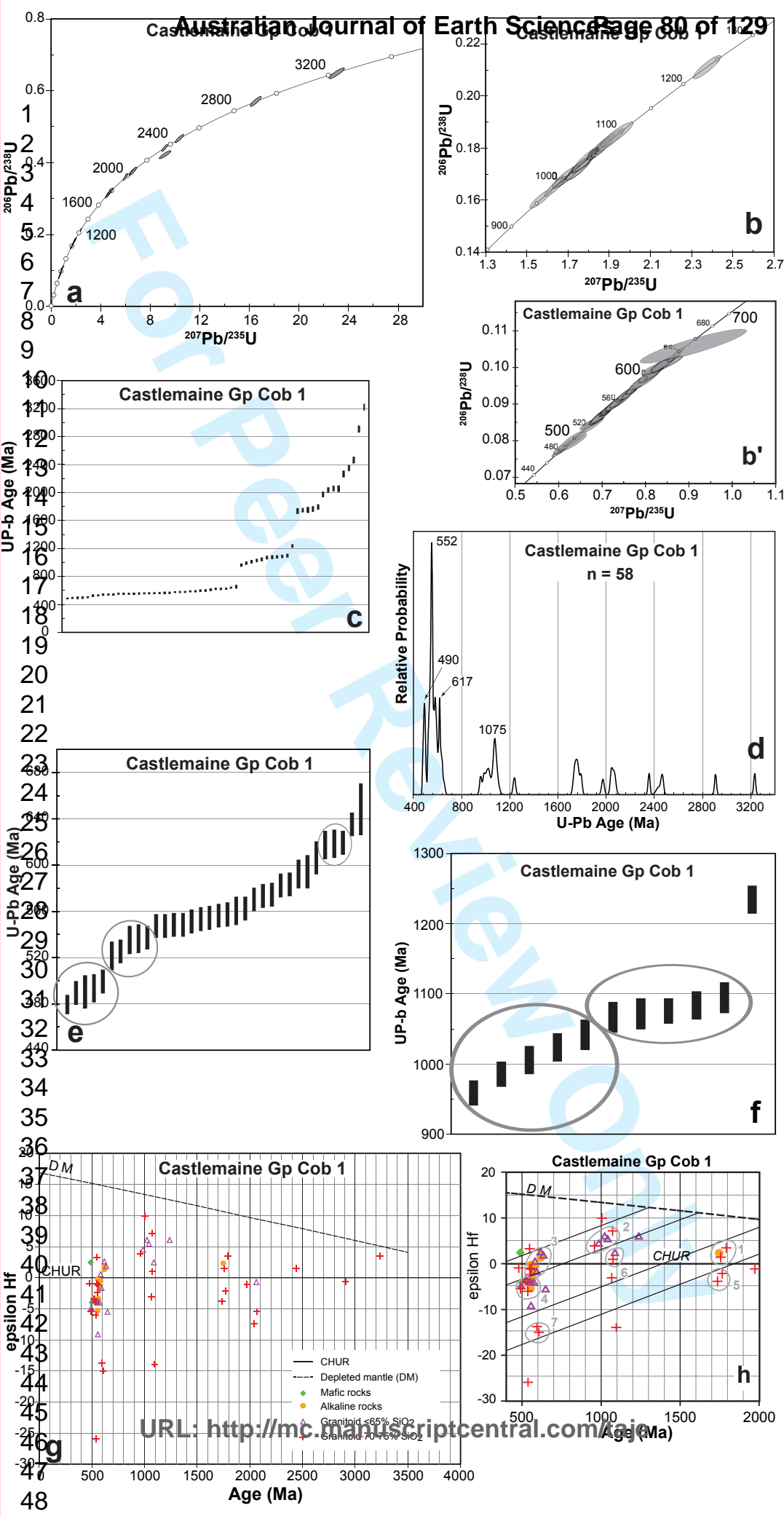




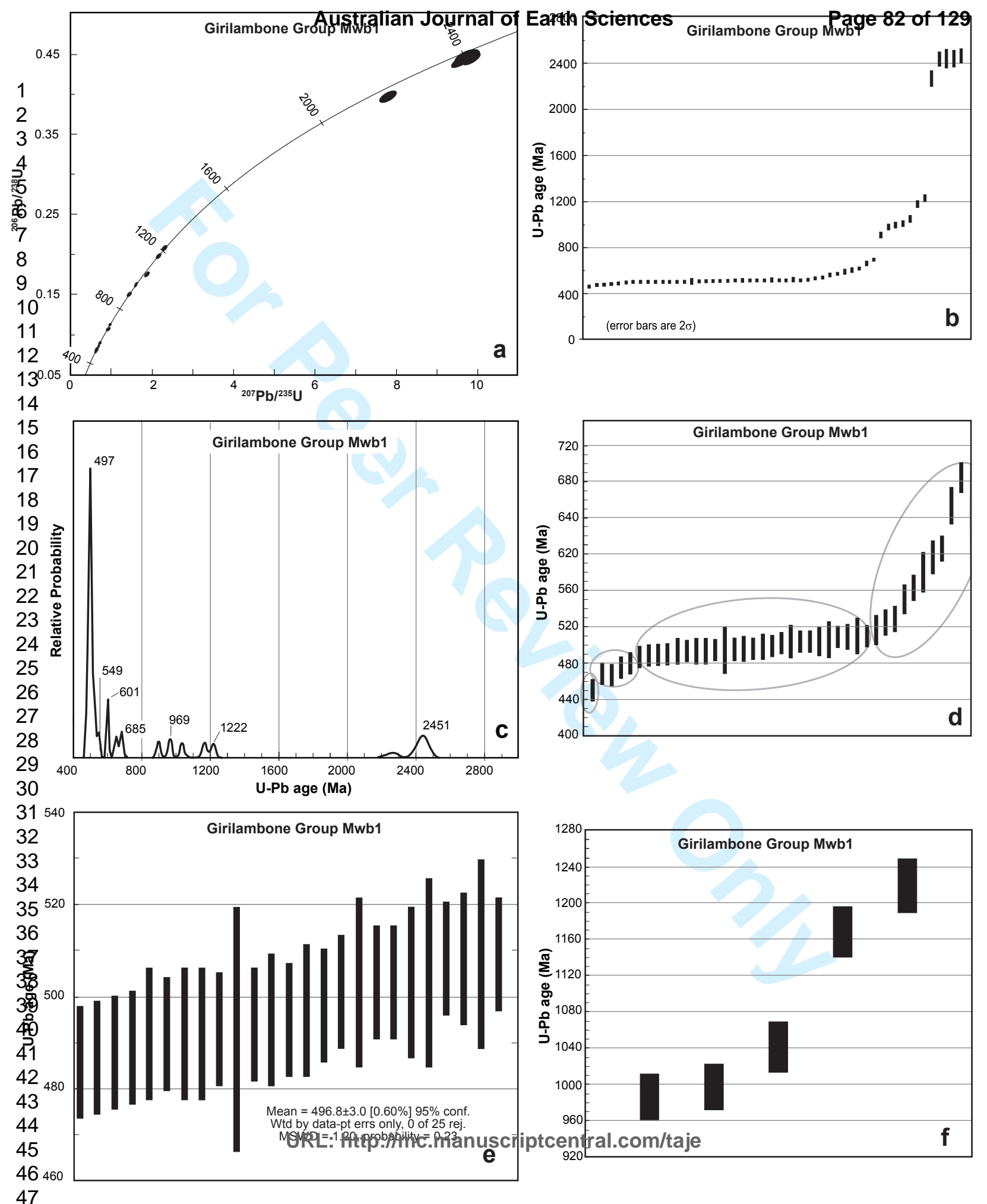




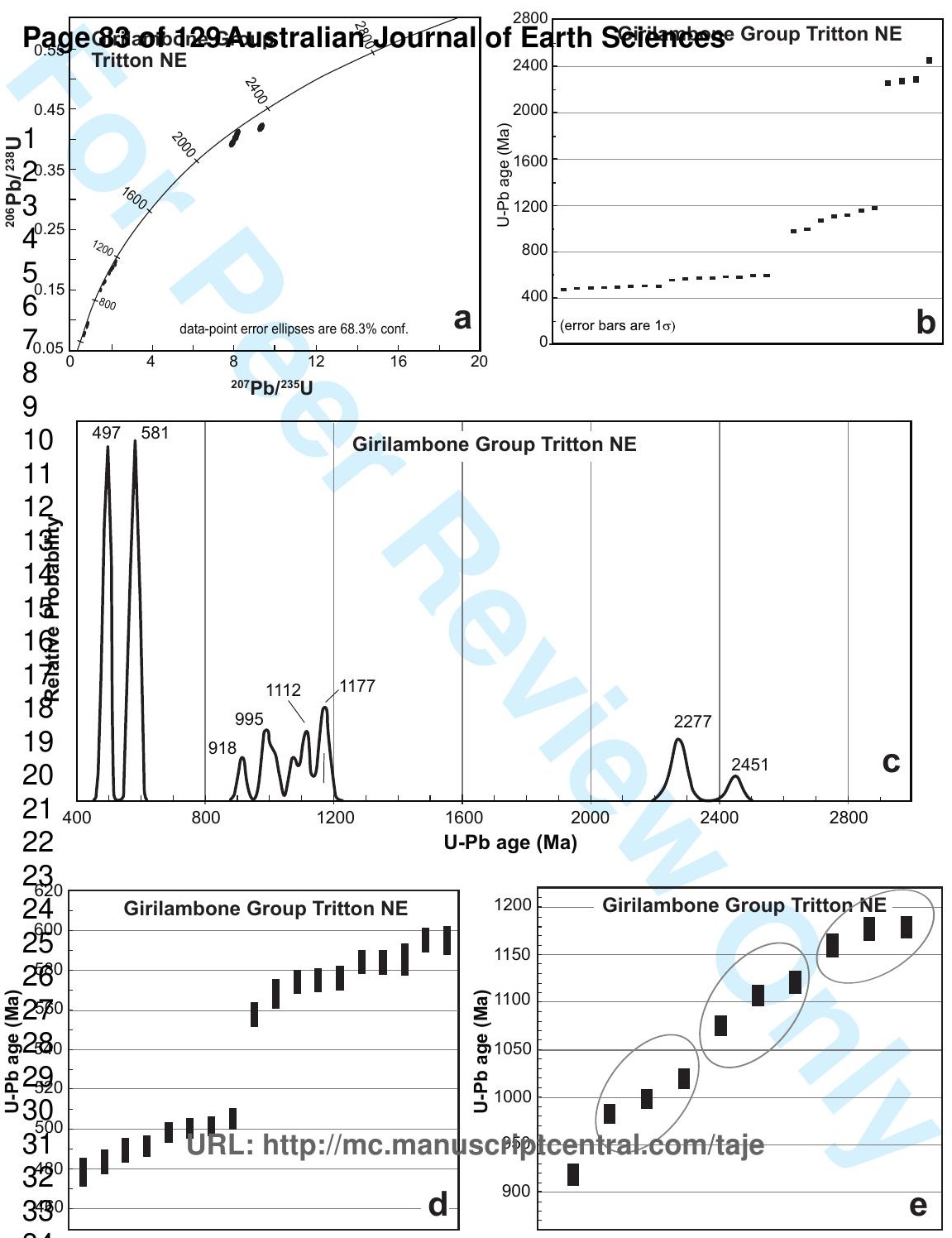




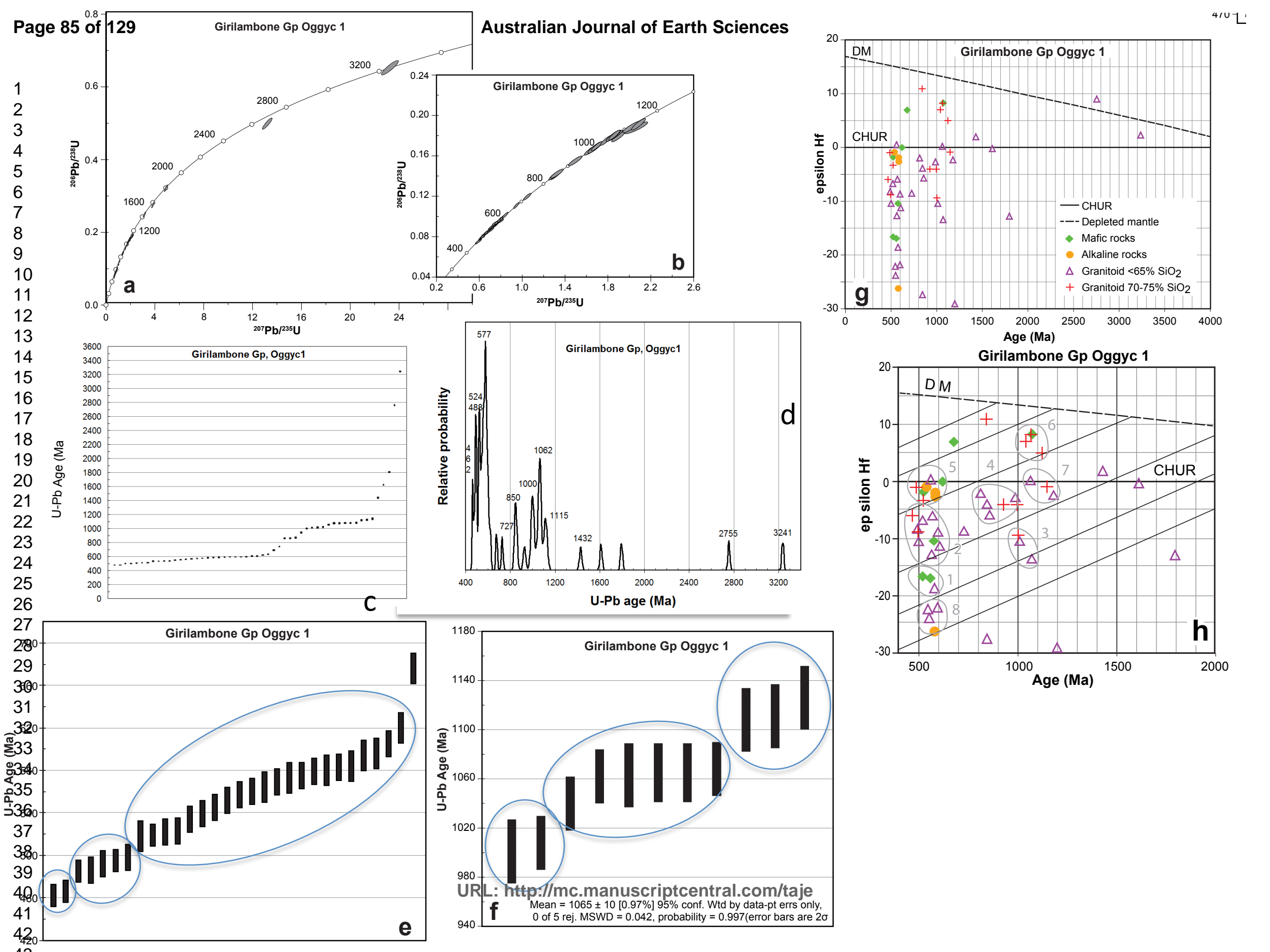




\section{Page 87 of 12gvagga Gp Oww 5 Austratia Journal of Earth Sciences}
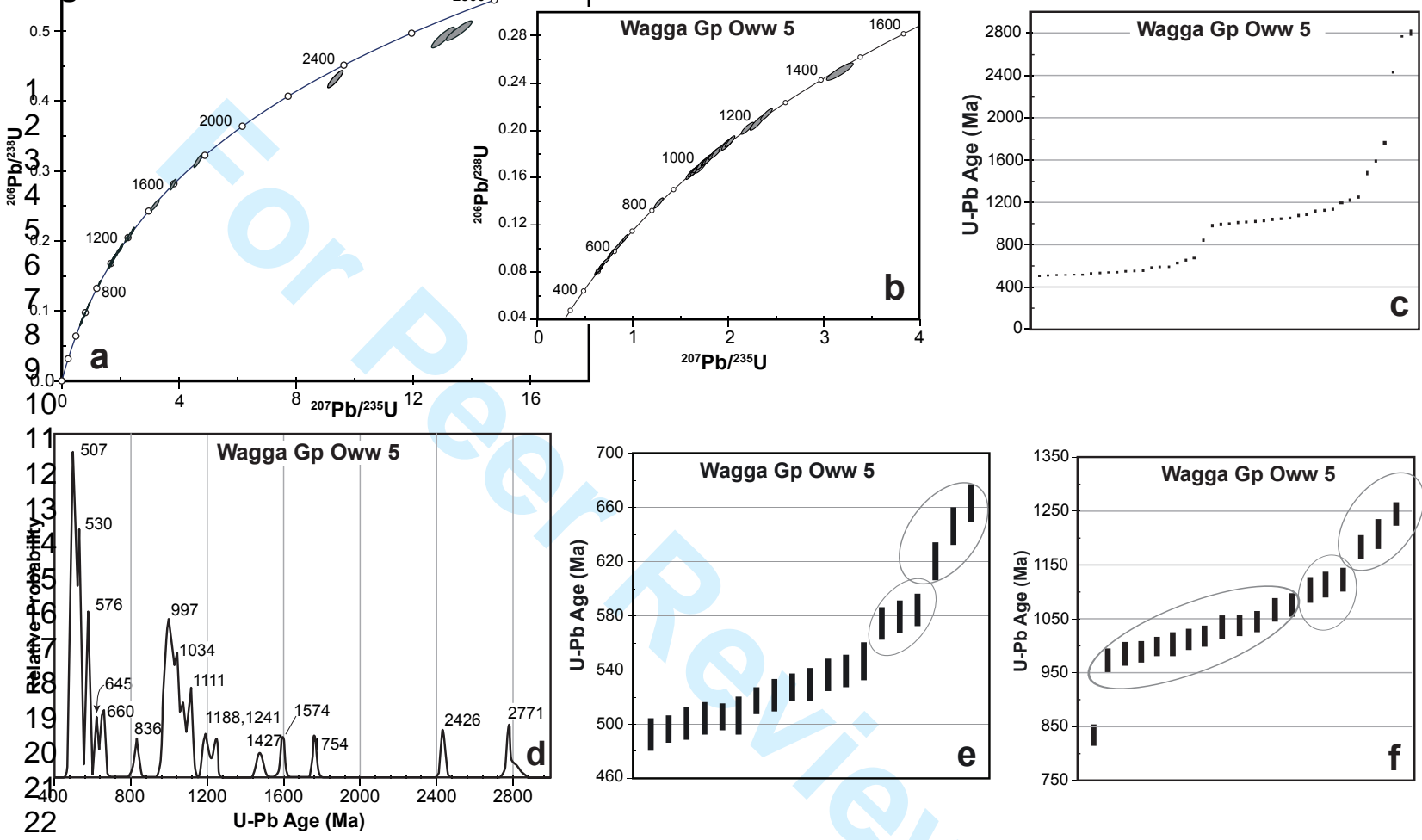

26
25
25
26
27
26

24
25
2
2
2
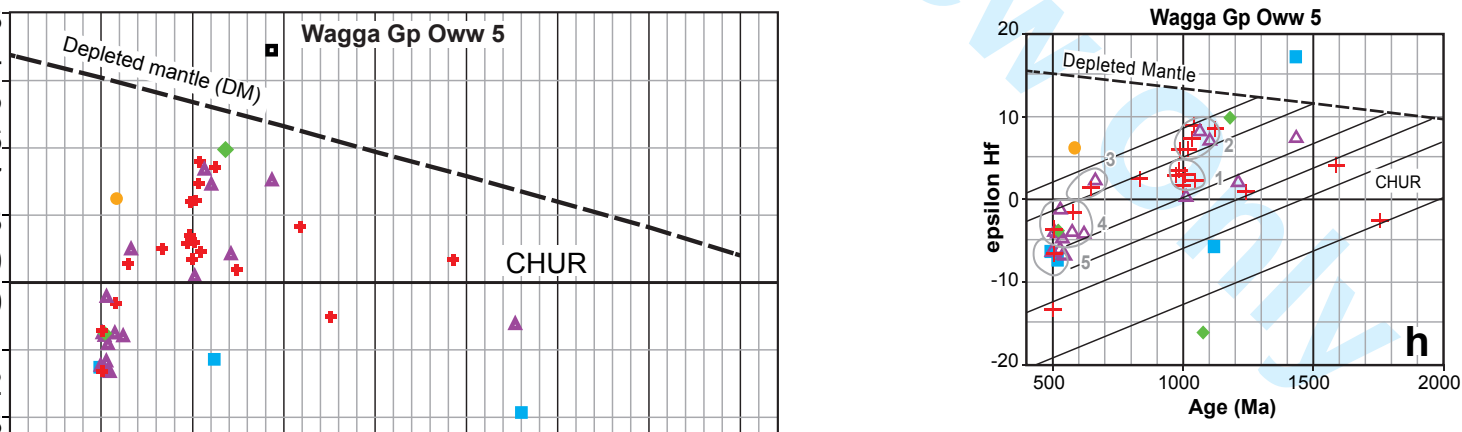

35

36

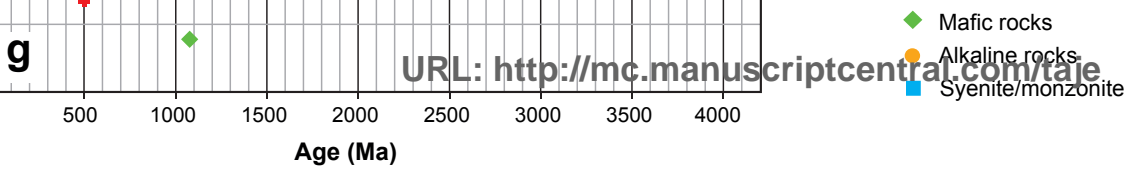

$\Delta$ Granitoid $<65 \%$ SiO2

+ Granitoid 70-75\% $\mathrm{SiO}_{2}$ 


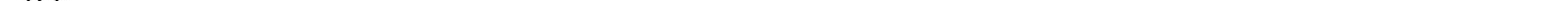



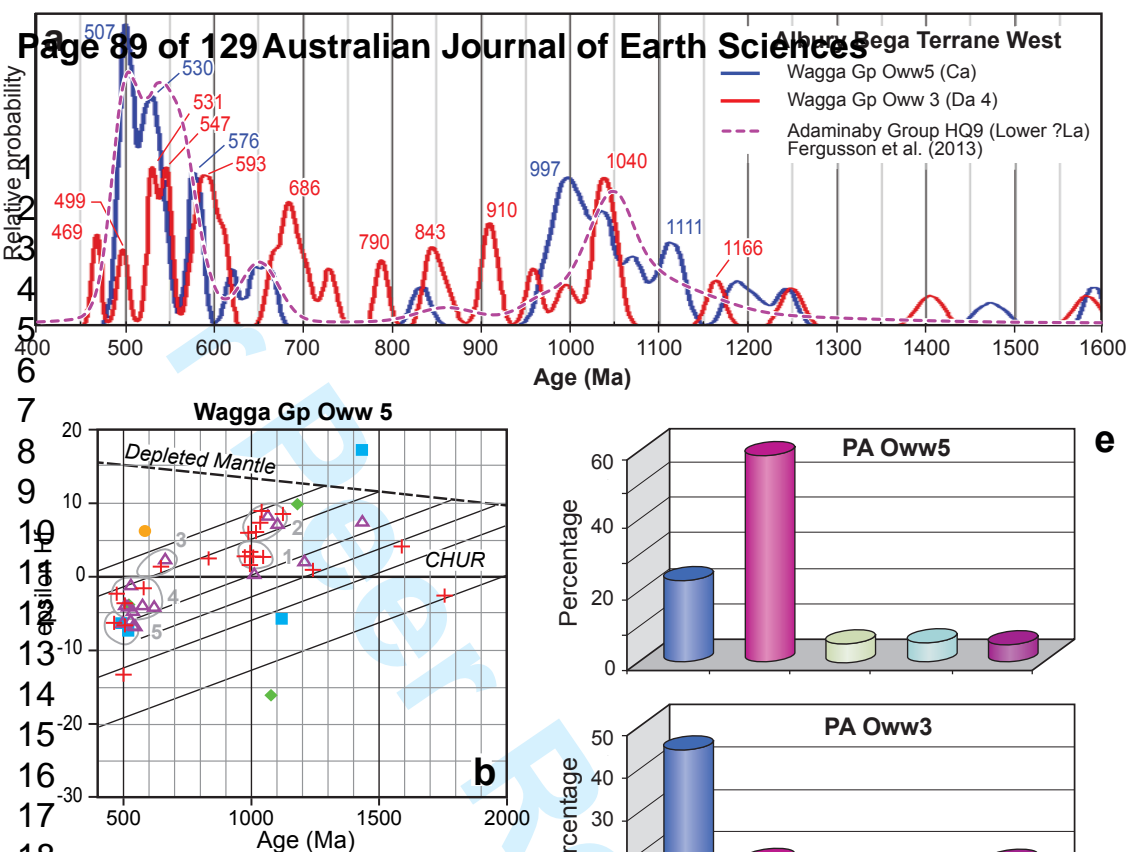

e
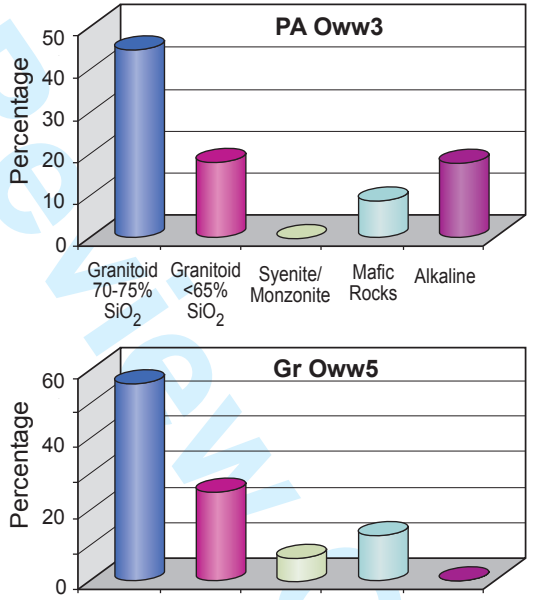

29

Wagga Gp Oww 3
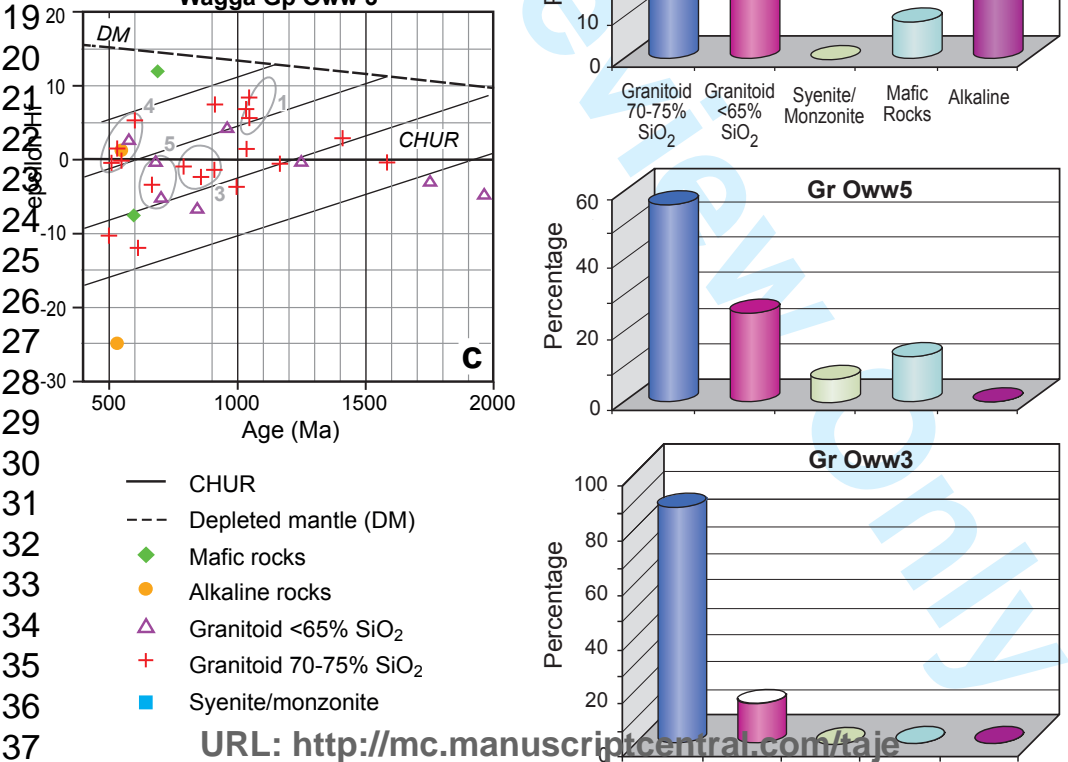


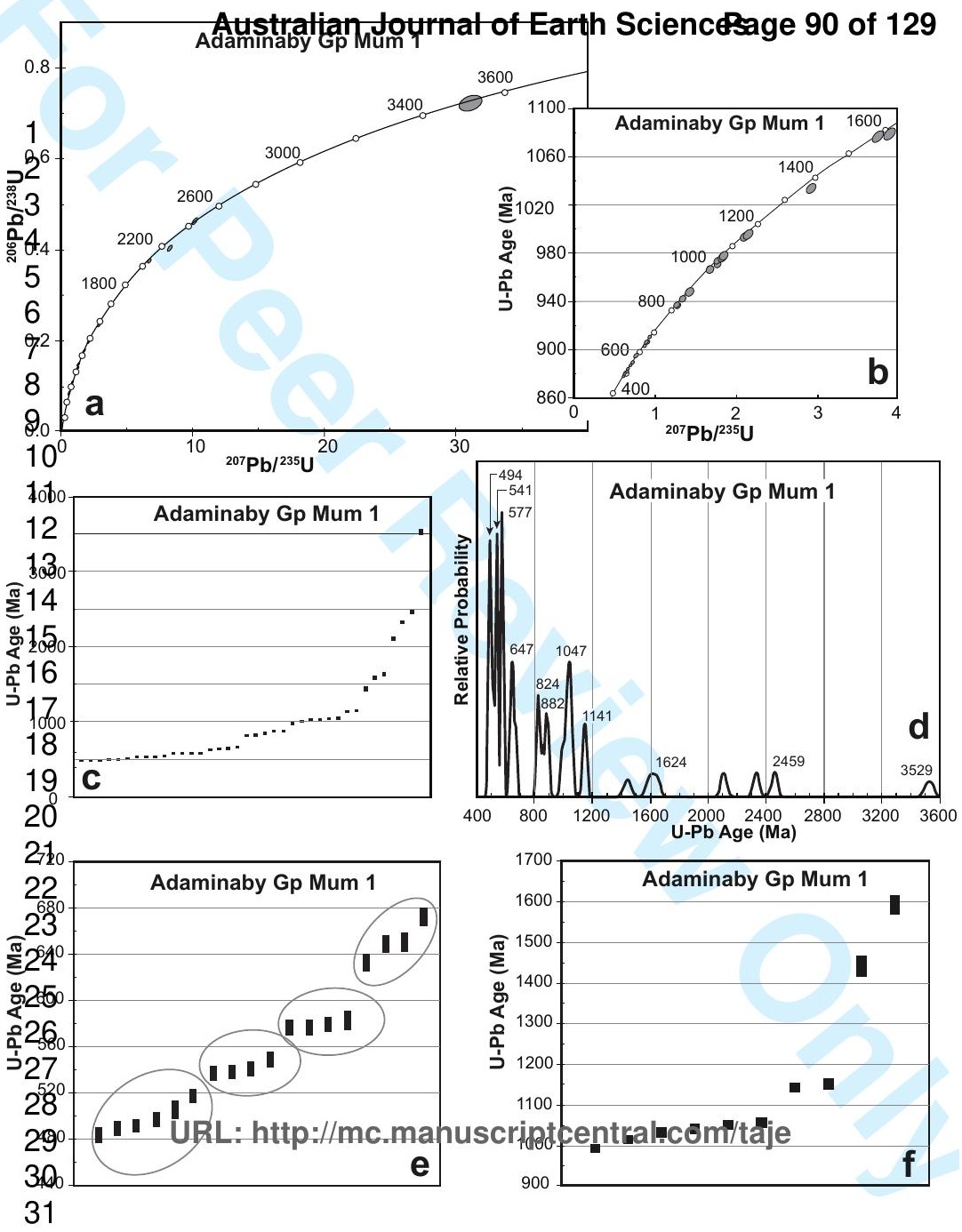




\section{Page 91 of 129ustraliangdeurnal of Earth Sciences}
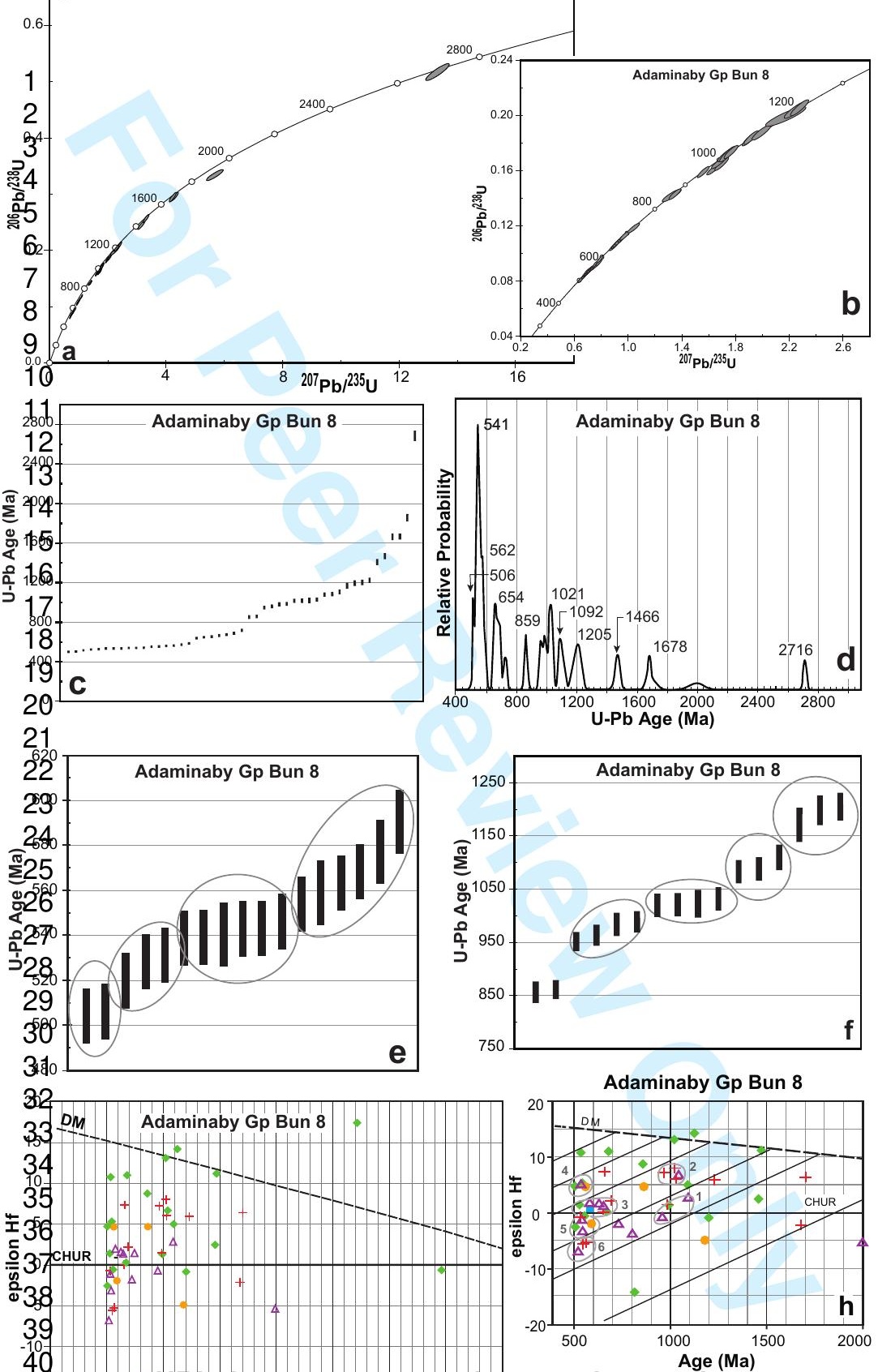

40

$-45$

4 URL: http://mc.manuscriptcentralcorm/taje $\Delta$ 9

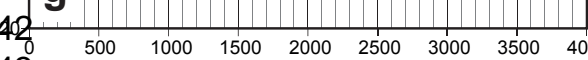

43

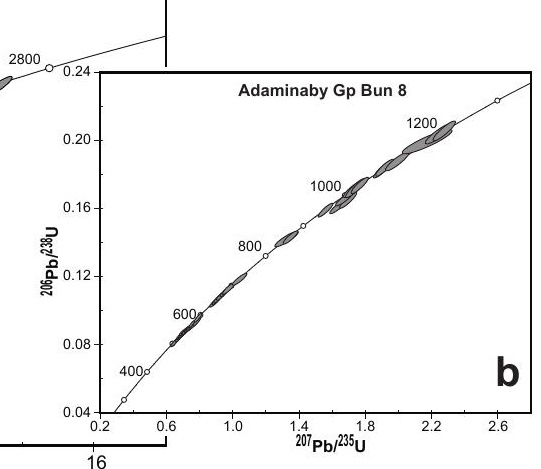

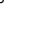




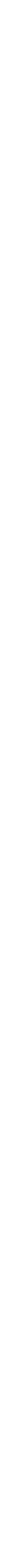




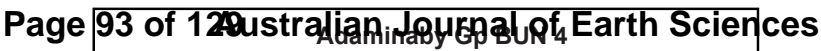
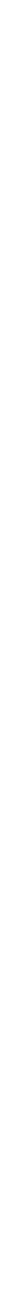

32

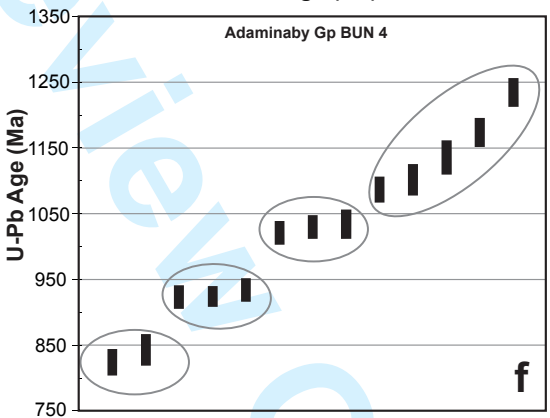

33

34

35

35

3द्व

$3 \frac{10}{20}$

39

40

4

4

4

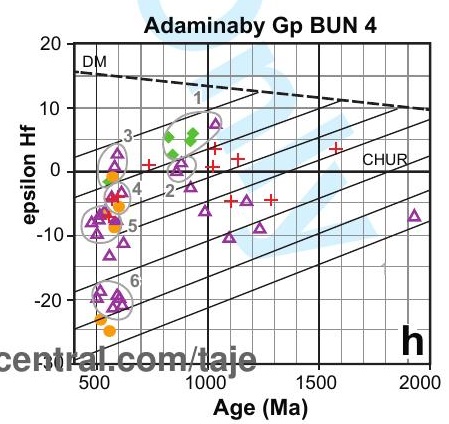

$$
30003500 \quad 4000
$$




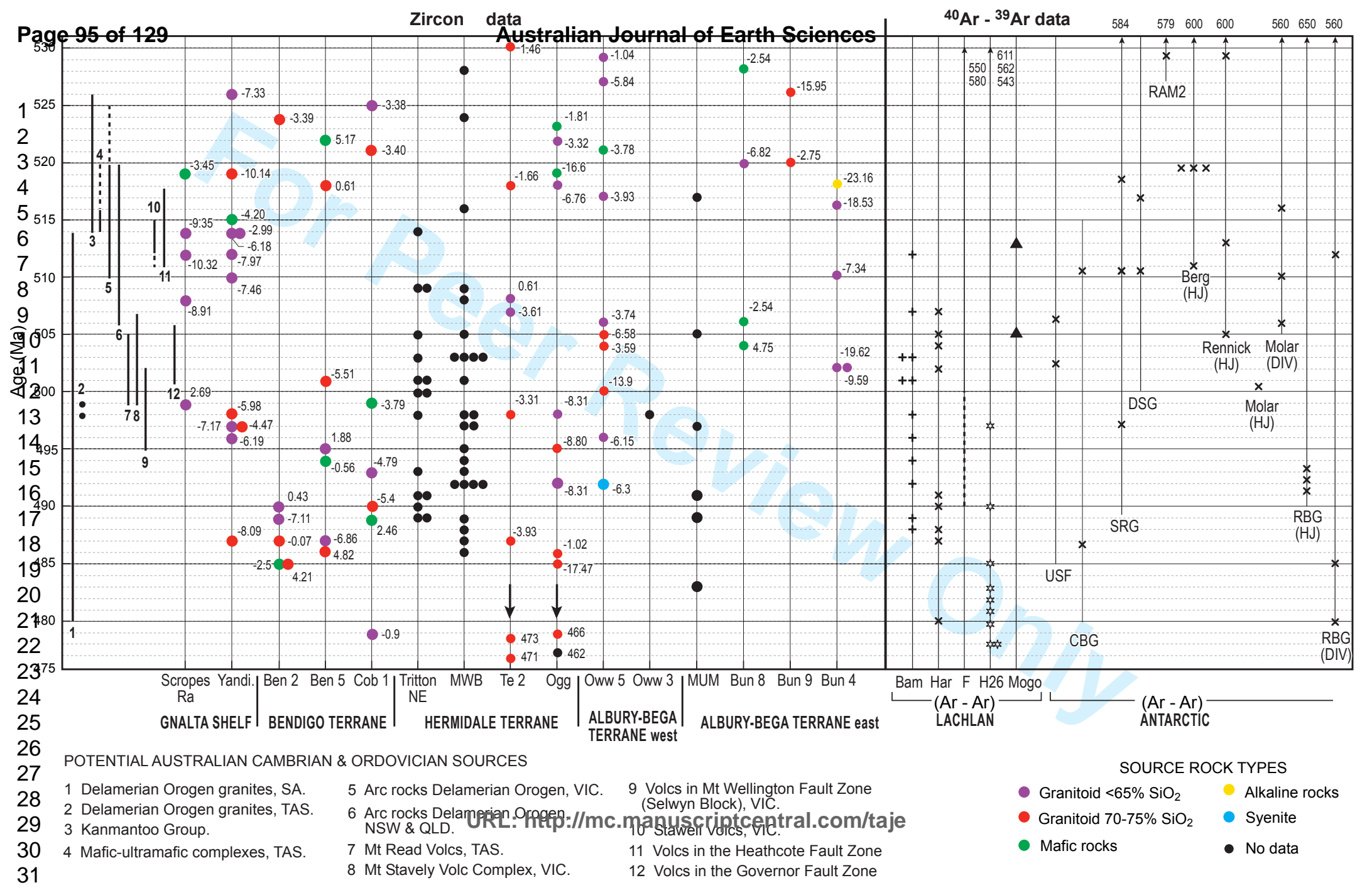




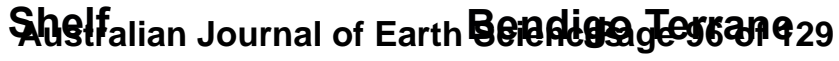
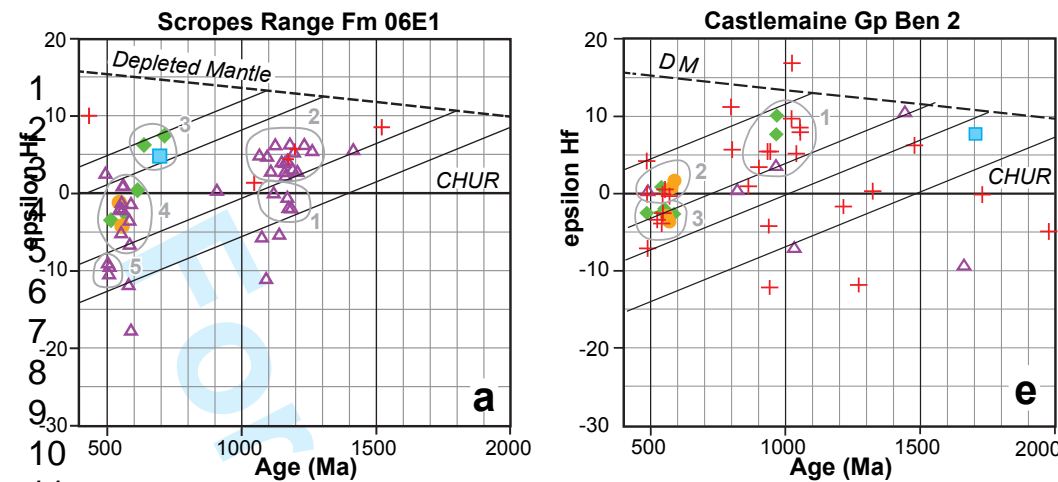

11
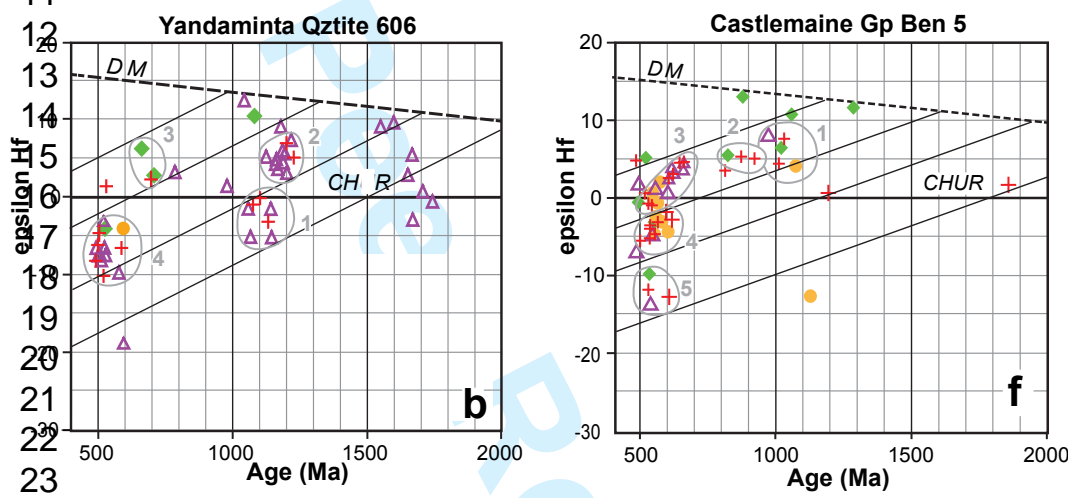

24 Hermidale Terrane

25
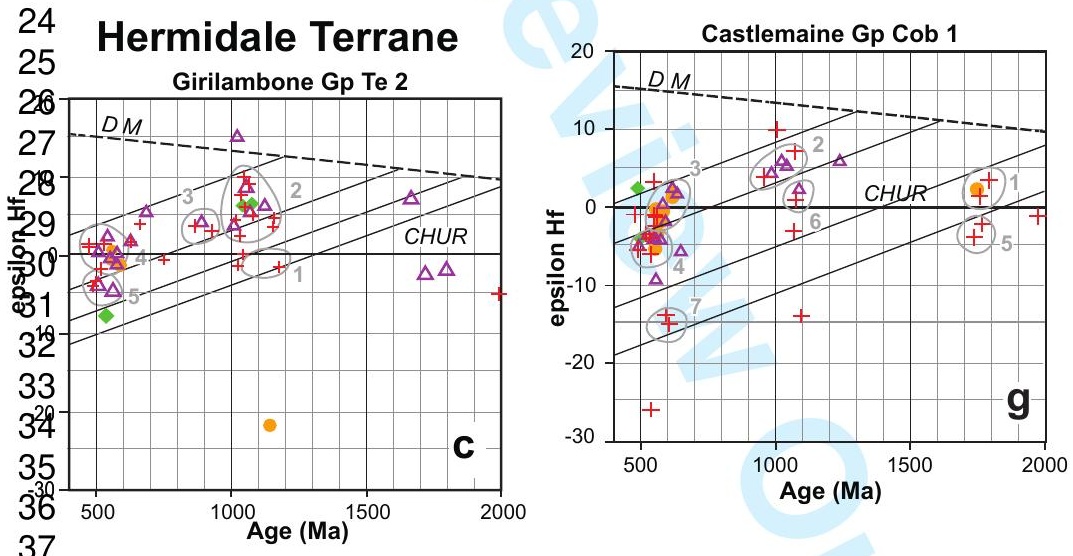

3
3
3
4
$\frac{4}{4}$
$\frac{9}{0}$
9
4
4
4
4
4
4

3
39
40
$\frac{4}{4}$
$\frac{9}{5}$
4
4
4
4
4
4
4

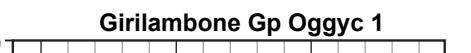



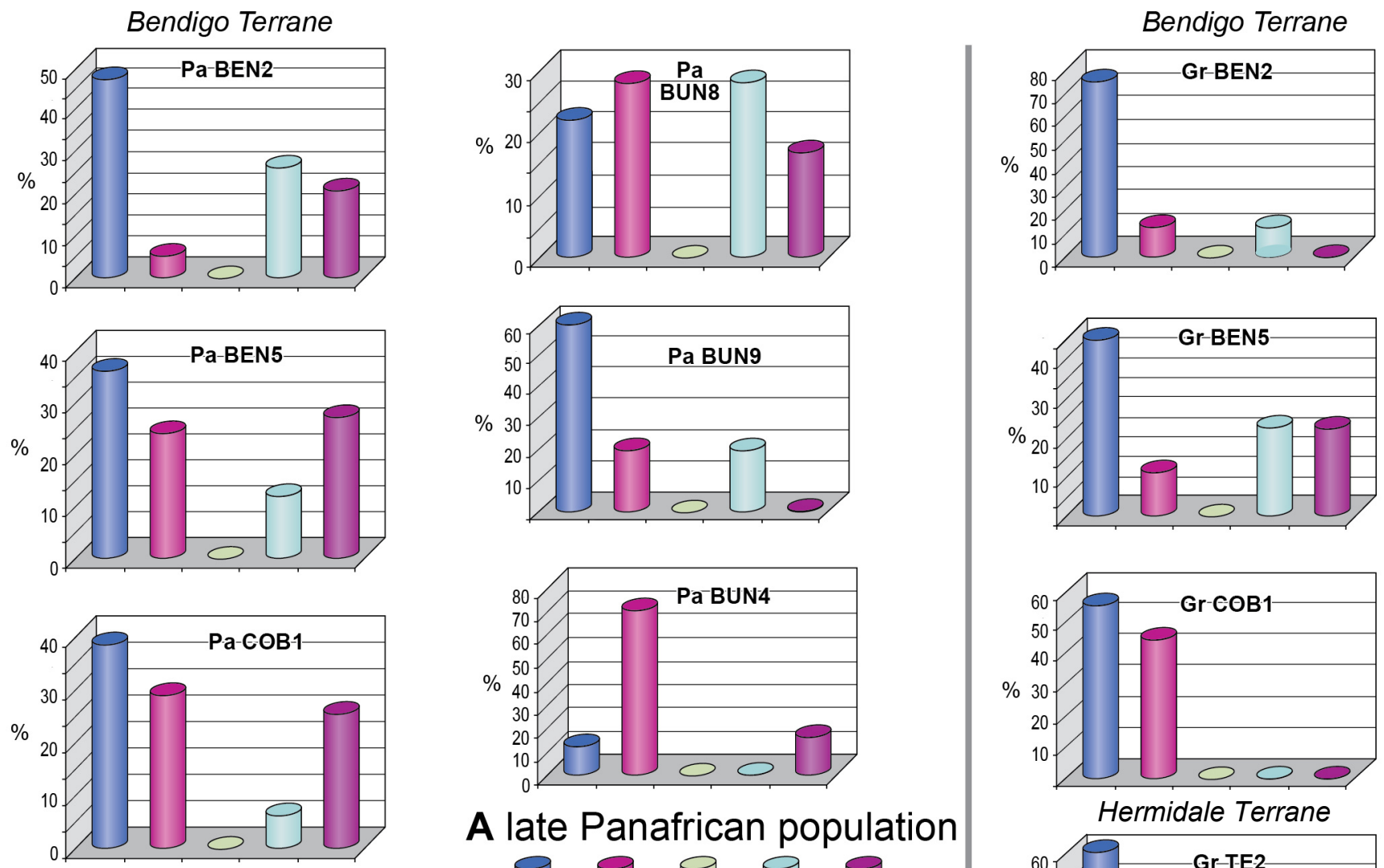

A late Panafrican population
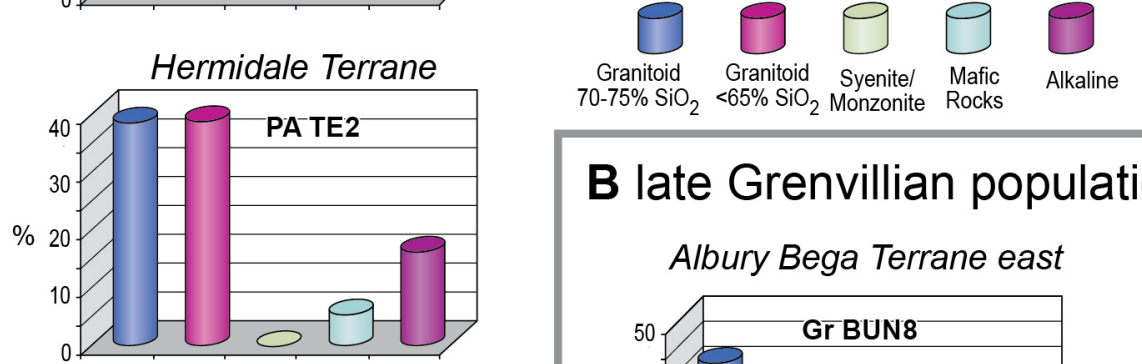

\section{B late Grenvillian population}

Albury Bega Terrane east
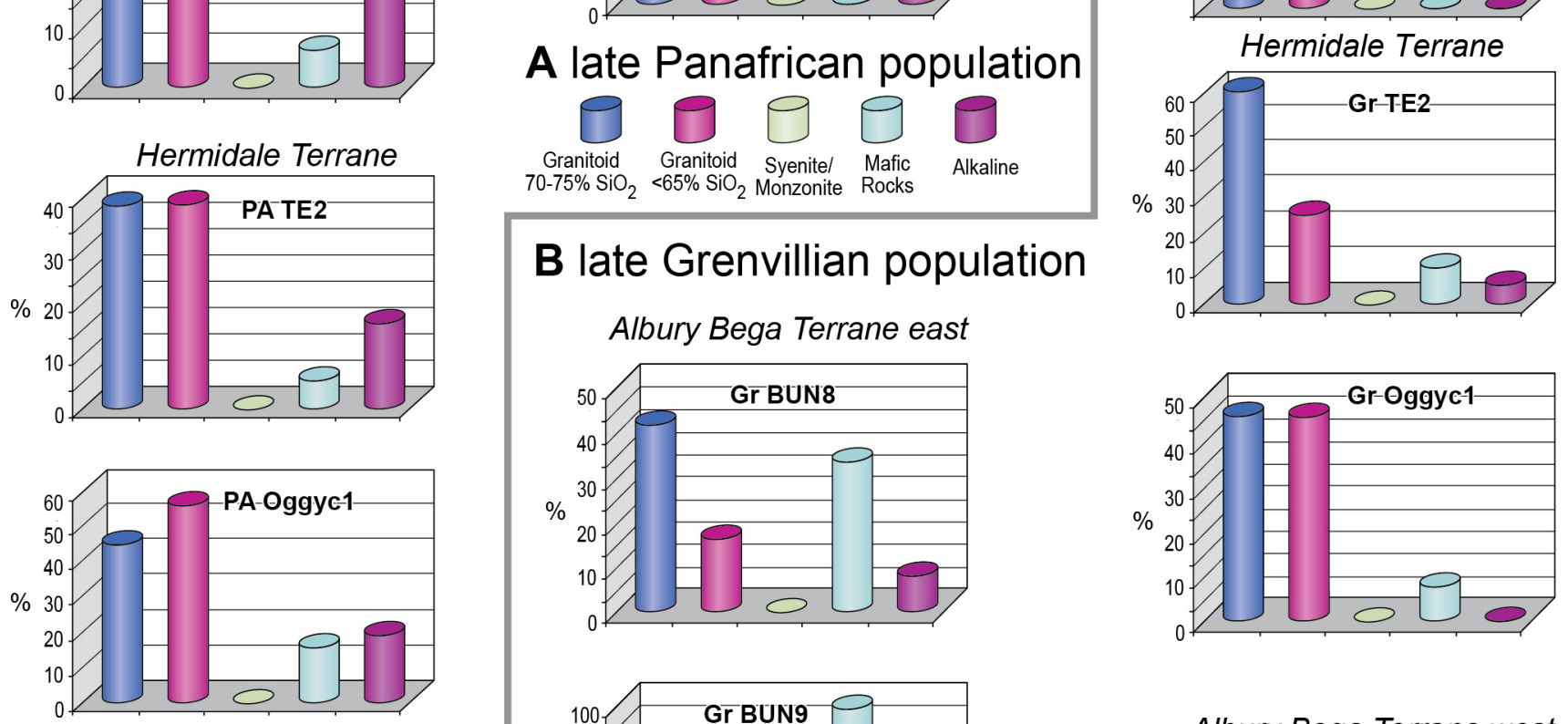

Albury Bega Terrane west
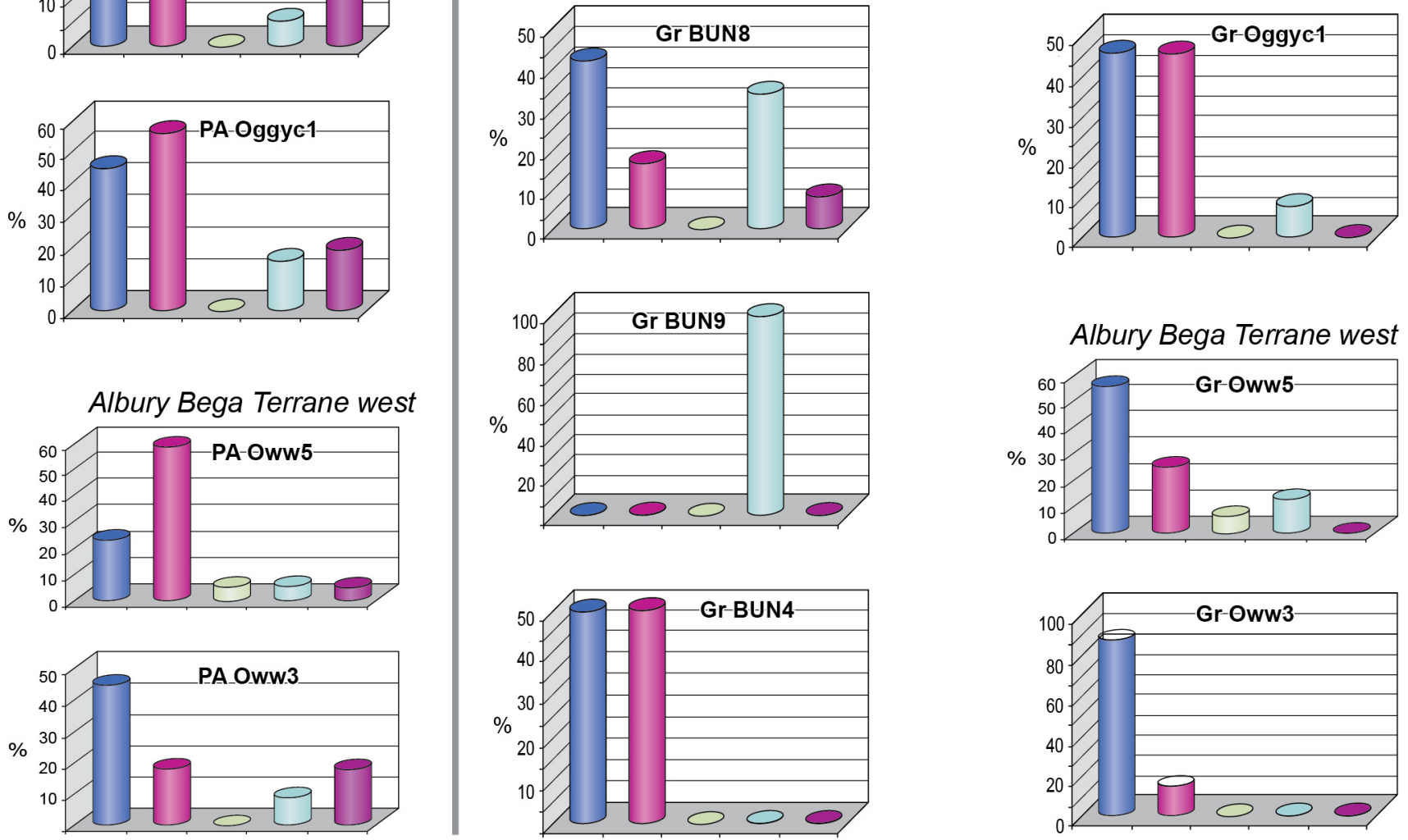
5

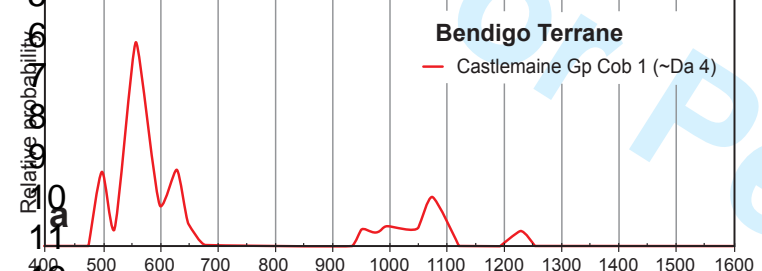

42

13

13

15 5

16

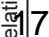

18

199

2

1

क्षे

氛4

25

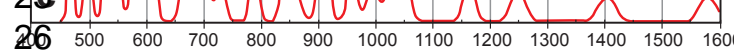

형

हुํํ

30

अ

308

34
Austratian Journal of Earth Sciences

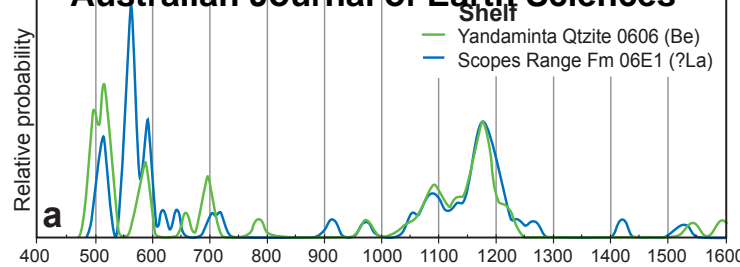

$\begin{array}{llllllllllllll}400 & 500 & 600 & 700 & 800 & 900 & 1000 & 1100 & 1200 & 1300 & 1400 & 1500 & 1600\end{array}$
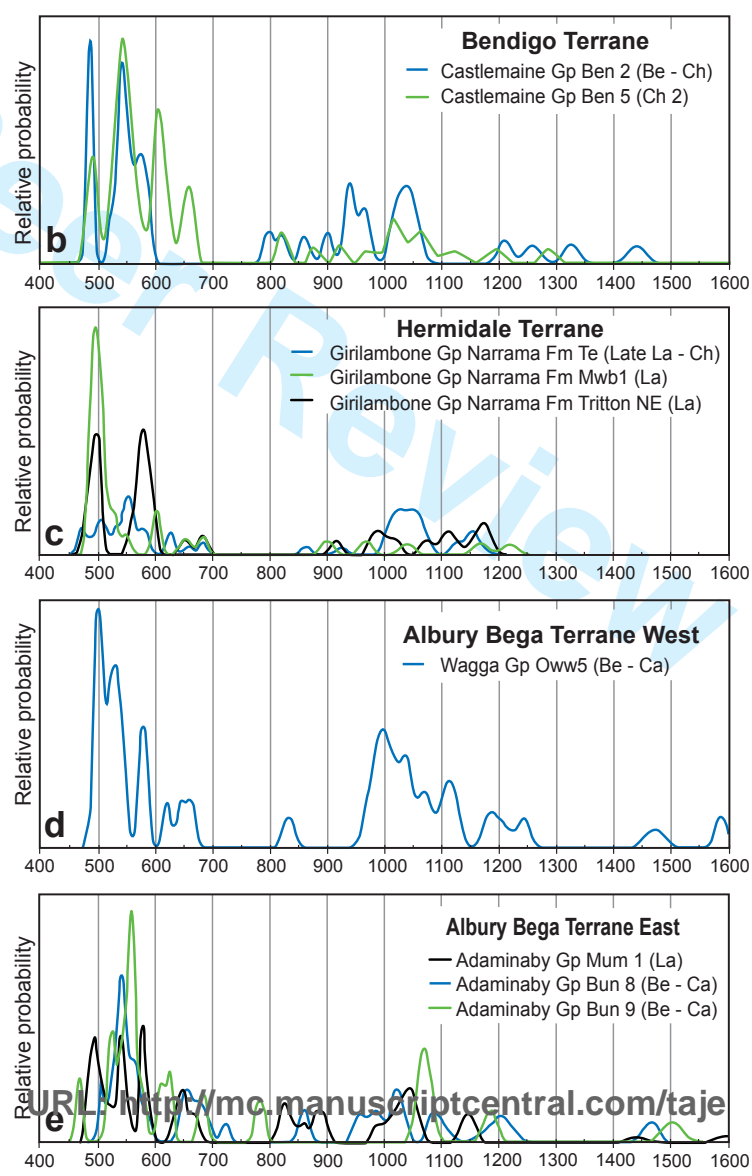

age (Ma)
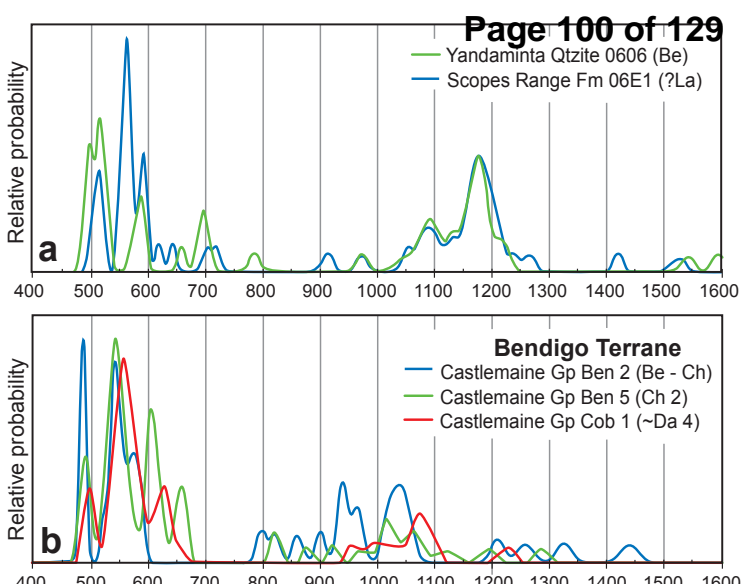

Mondon acon

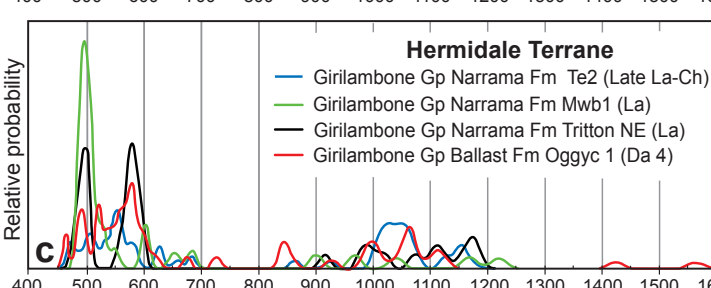

$\begin{array}{llllllllllllll}400 & 500 & 600 & 700 & 800 & 900 & 1000 & 1100 & 1200 & 1300 & 1400 & 1500 & 1600\end{array}$
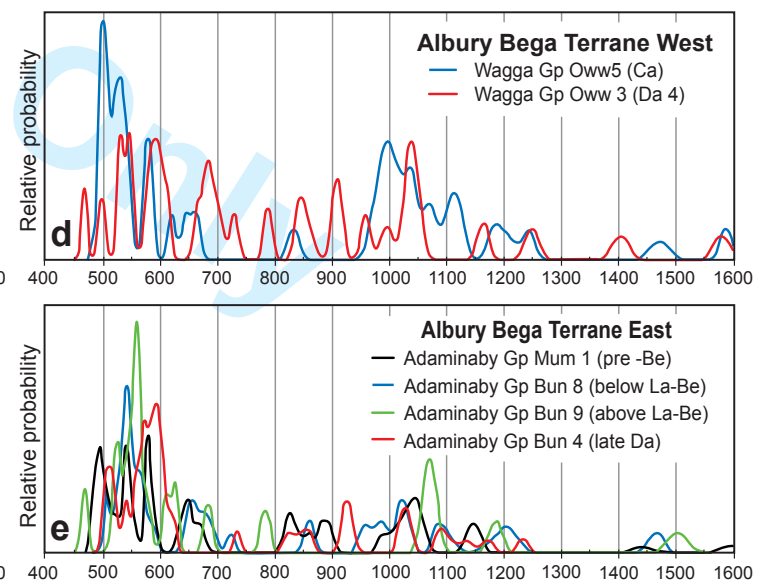

age (Ma) 

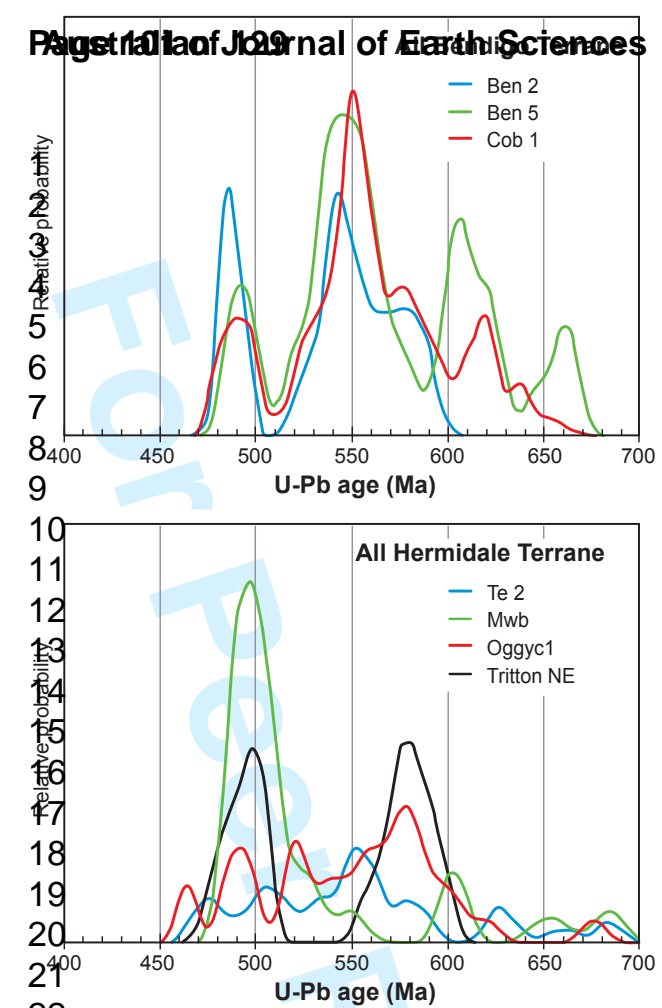

22

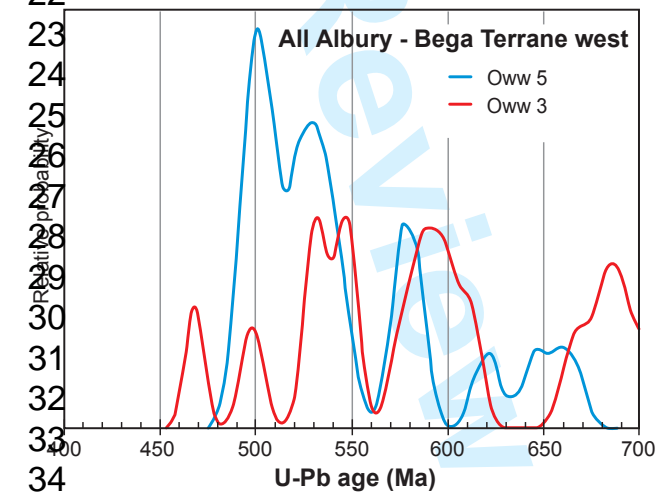

35

36

37

38

39

部

$\$ 1$

42

43

44

UF

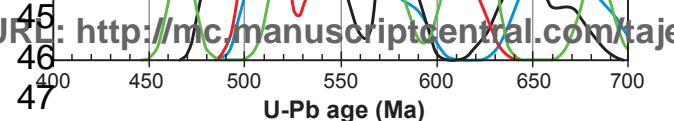

48 


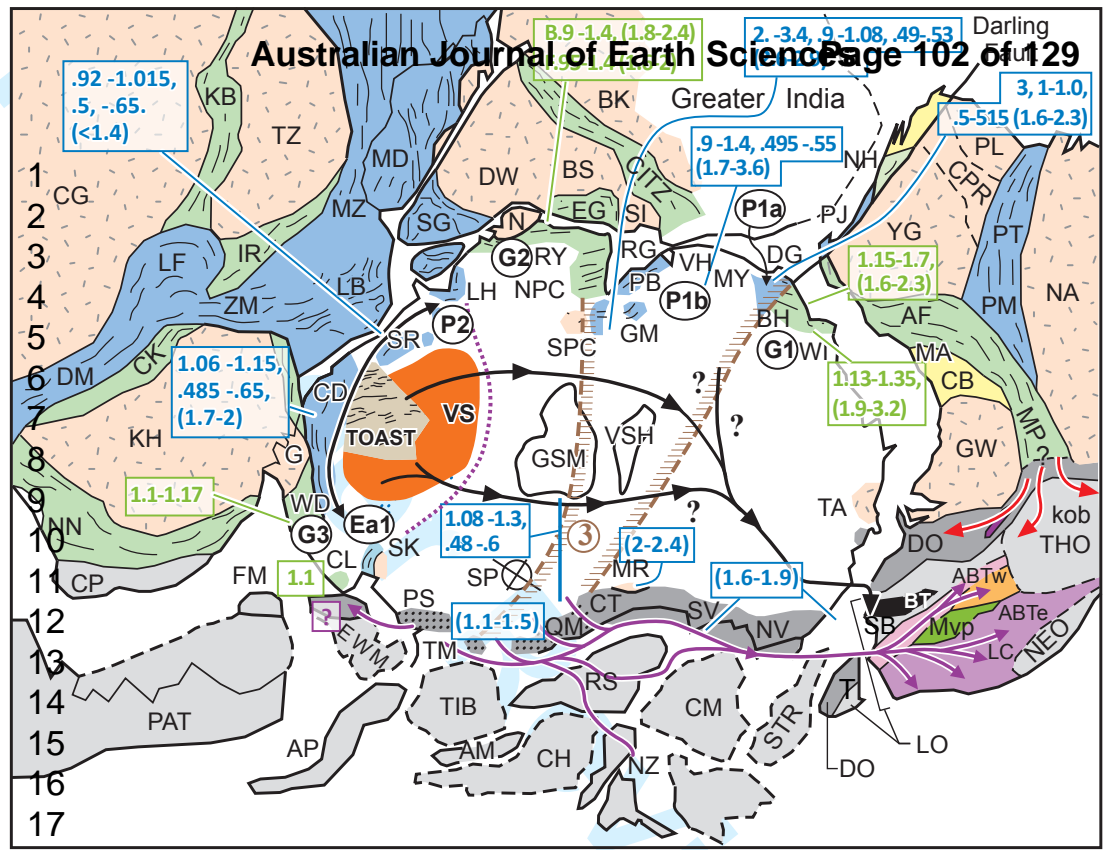

18

10 Outboard terranes (ANT) and

orogens (AUST)

20 Ross Orogen

21 (EWM+PS+TM+QM+Ct+SV +NV) \&

Delamerian Orogen (DO, AUST)

22 Panafrican belts ( $P 1)$

23 Grenville-age belts (G1)

24

25

26 Pre-Grenville cratons

27 INFERRED SUPPLY PATHS

28 Castlemaine Group

(Bendigo Terrane)

29 Shelf rocks, kob + part of Adelaide Rift

30

31

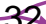
Orogen (THO)

Adaminaby + Wagga + Girilambone gps

(Albury-Bega, + Hermidale terranes)

TOAST: Tonian Oceanic Arc

Super Terrane (Jacobs et al. 2015)

vs: subglacial source inferred by

Veevers \& Saeed (2013)

臀寻 (3) Belt PD3

Ea1) East African - Antarctic Orogen

1.13-1.35,- Ages

(1.9-3.2) - Model basement ages

\section{ORDOVICIAN TURBIDITE TERRANES,} LACHLAN OROGEN

Bendigo Terrane

Hermidale Terrane

AlkermB'eaj̇errane west

Albury - Bega Terrane east

Macquarie volcanic province ) 


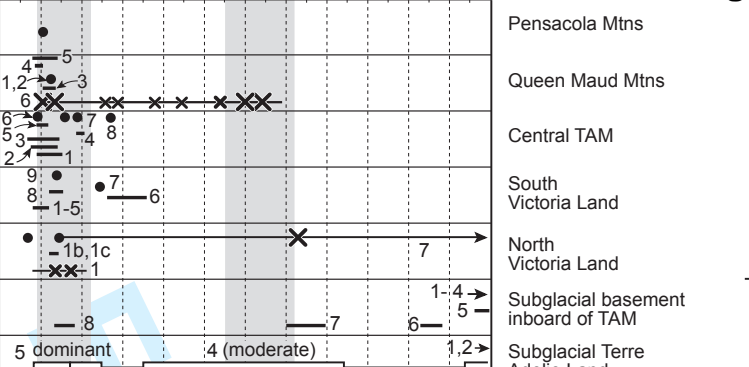

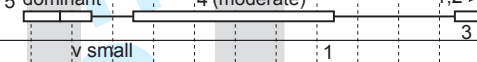

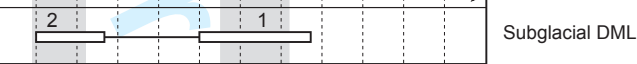

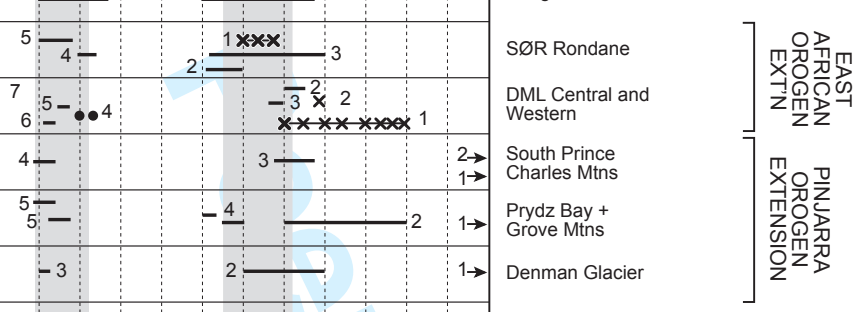

44
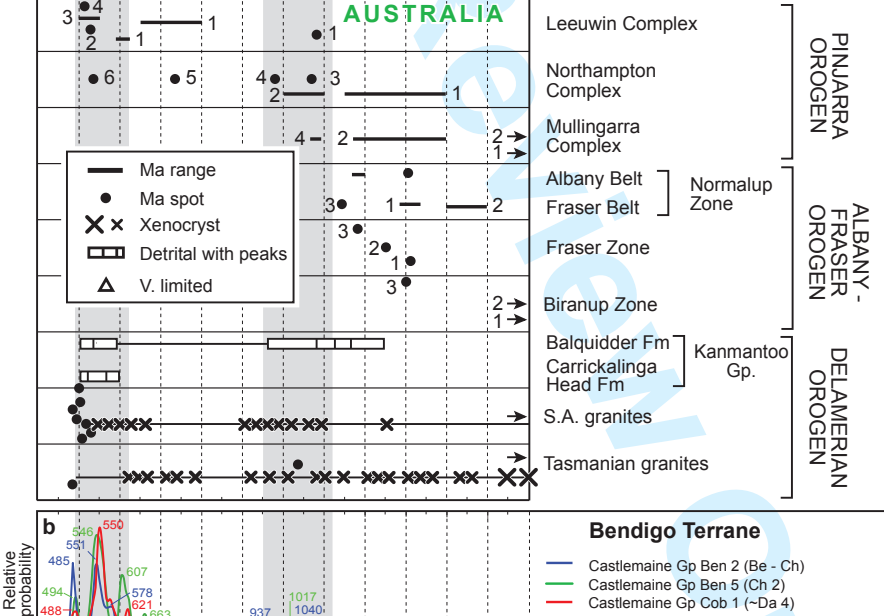

- Castlemaine Gp Cob $1(\sim \mathrm{Da} 4)$
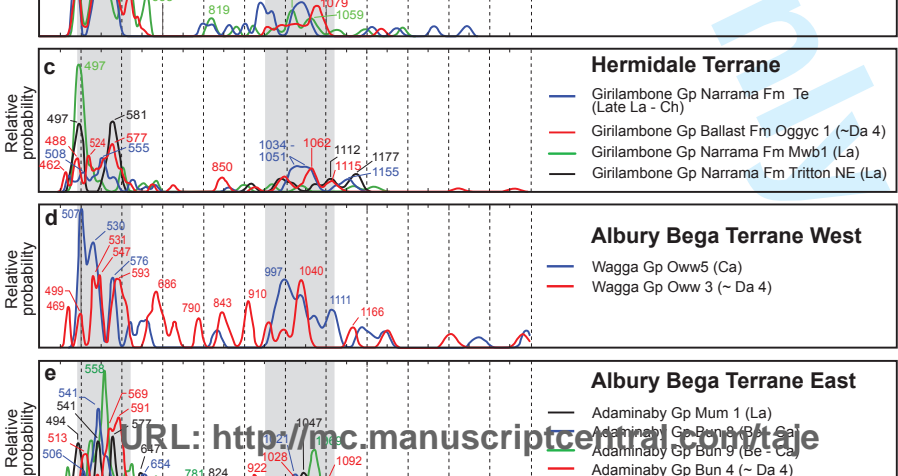
52

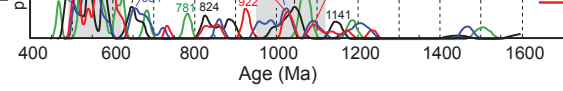




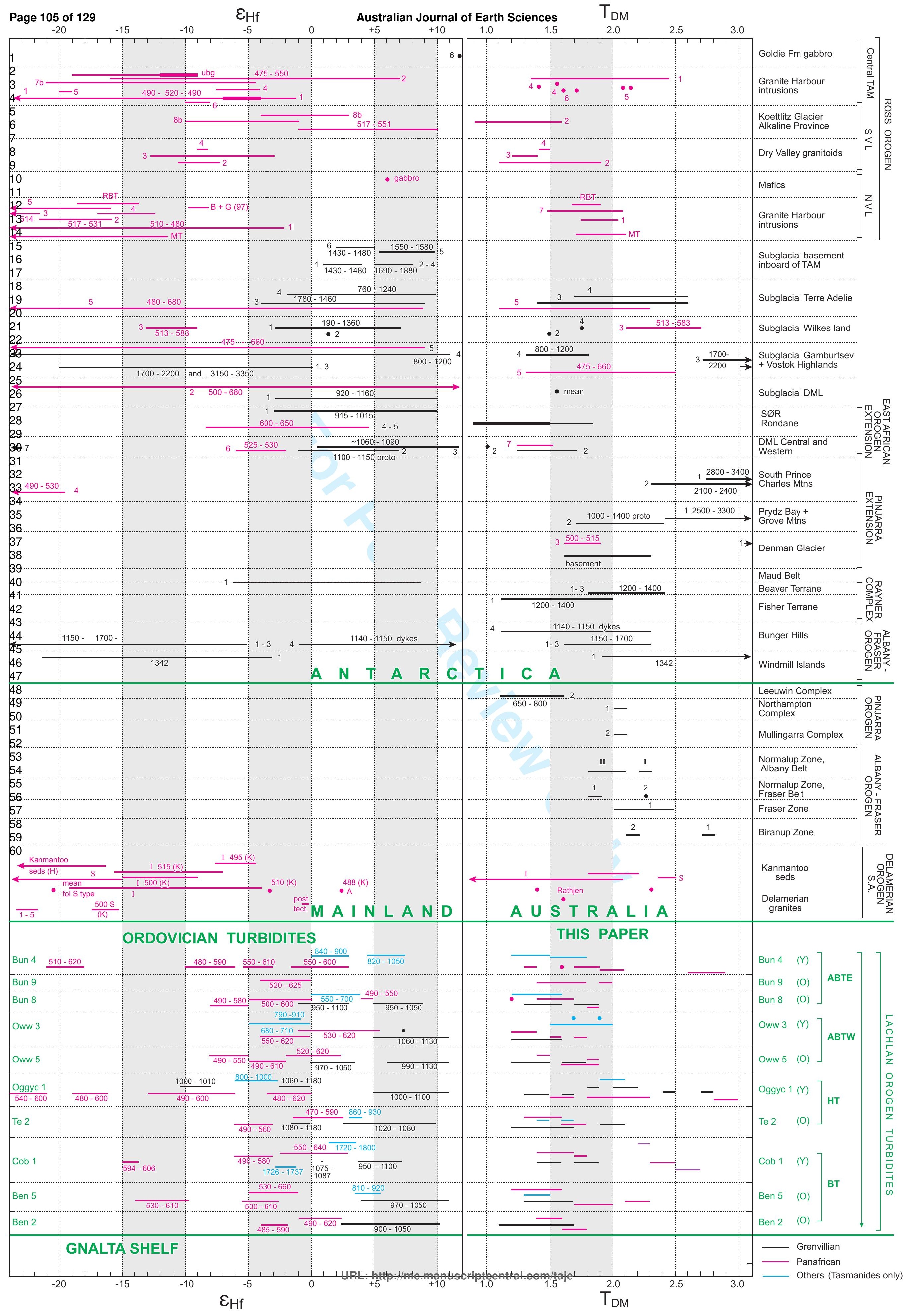




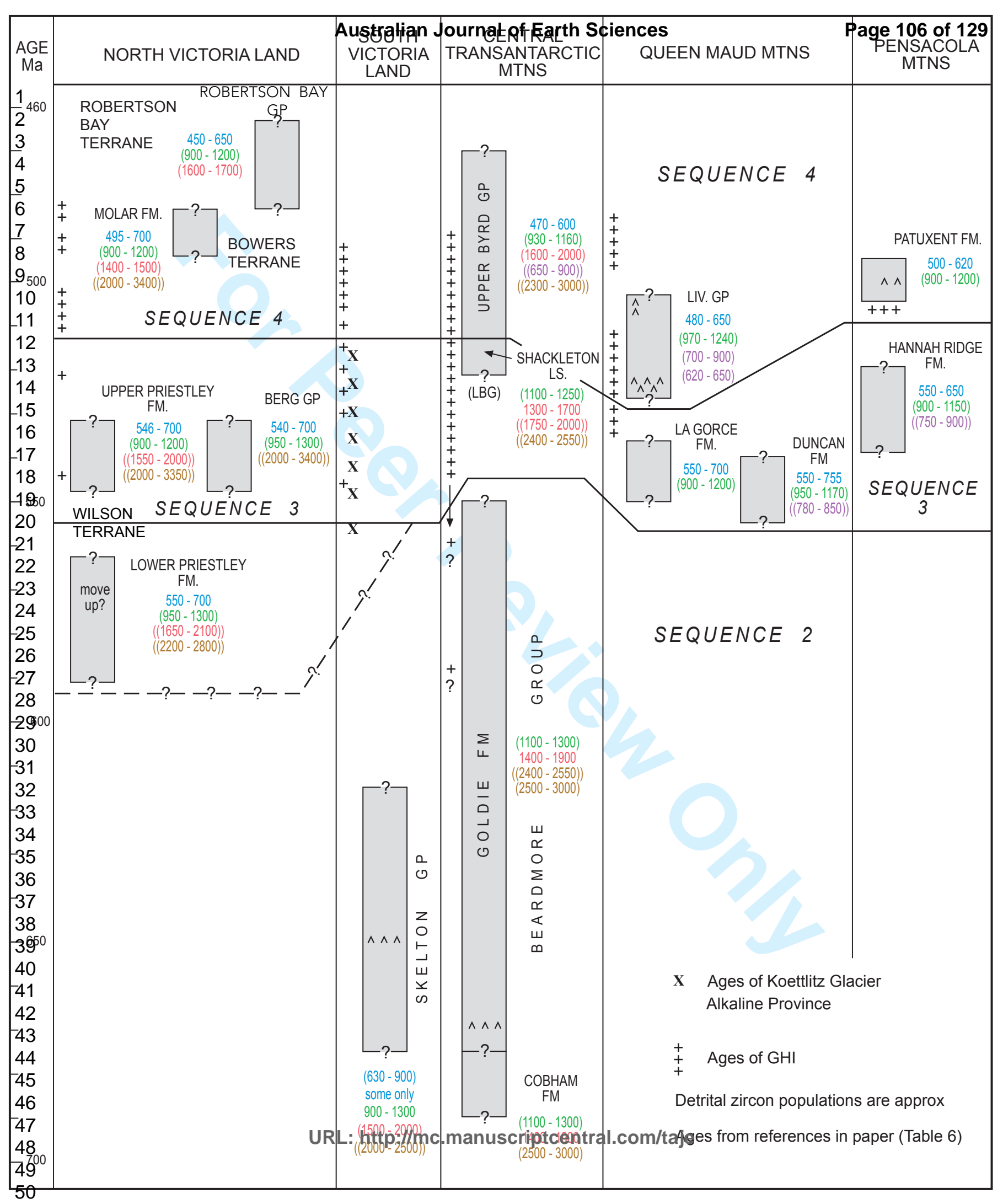


Table 1. Ordovician terranes, descriptions and location.

\begin{tabular}{|c|c|c|}
\hline $\begin{array}{l}\text { Terrane/lithotectonic } \\
\text { association }\end{array}$ & Description & Sources \\
\hline $\begin{array}{l}\text { Lower to Middle } \\
\text { Ordovician turbidites } \\
\text { and Late Ordovician } \\
\text { black shales in the } \\
\text { Lachlan Orogen } \\
\text { divided into several } \\
\text { terranes (Glen et al. } \\
\text { 2009). }\end{array}$ & $\begin{array}{l}\text { (i) Albury-Bega Terrane, in which dominant black shales of the Upper } \\
\text { Ordovician Bendoc Group lies above Lower to Middle Ordovician turbidites } \\
\text { (including cherts) of the Adaminaby and Wagga groups } \\
\text { (ii) Hermidale Terrane, containing similar Lower to Middle Ordovician } \\
\text { turbidites, but lacking the Upper Ordovician Bendoc Group (Figure 1) } \\
\text { (iii) Bendigo Terrane, in which Lower to Middle Ordovician turbidites of the } \\
\text { Castlemaine Group lack cherts, but contain graptoliferous laminated grey } \\
\text { shales. They also lack an overlying upper Ordovician black shale } \\
\text { sequence. } \\
\text { (iv) Melbourne Terrane east of Bendigo Terrane comprises lowermost } \\
\text { Ordovician turbidites overlain by a Lower to Middle Ordovician condensed } \\
\text { shale and chert in the west and by scattered Upper Ordovician black shales } \\
\text { in the east. } \\
\text { The eastern and western parts of the Albury-Bega Terrane are separated by } \\
\text { coeval Macquarie Volcanic Province. Many of the cherts are actually fine- } \\
\text { grained, black siliceous siltstones. }\end{array}$ & $\begin{array}{l}\text { Bruce and Percival (2014) reported geochemical } \\
\text { changes in clay-sized material in the Lower and } \\
\text { late Middle Ordovician chert packets (in the, } \\
\text { Hermidale Terrane) and Albury-Bega Terrane } \\
\text { east): the Lower Ordovician chert packet } \\
\text { contained two mixed sources, one Gondwanan } \\
\text { (inferred to be Cambrian ocean crust that had } \\
\text { been modified by subduction and accreted to } \\
\text { Gondwana with subsequent melting) and one } \\
\text { from a more juvenile continental crust, equal to a } \\
\text { post-Archean Australian source. The late Middle } \\
\text { Ordovician chert packet contained an upward } \\
\text { change from these two sources into a Gondwana- } \\
\text { only source. }\end{array}$ \\
\hline Narooma Terrane & $\begin{array}{l}\text { Defined at Narooma as an intact stratigraphic sequence, passing upwards from } \\
\text { Middle Cambrian to Middle Ordovician chert into Late Ordovician siltstone, } \\
\text { interbedded chert + siltstone and then into a broken formation with blocks of } \\
\text { sandstone, vesicular basalt and ?older chert, all cut by east and west-dipping } \\
\text { faults (Glen et al. 2004). Relationship to other Ordovician or inferred Ordovician } \\
\text { units around Batemans Bay not established (see summary by Packham \& } \\
\text { Hubble 2016) }\end{array}$ & $\begin{array}{l}\text { Some authors (e.g. Fergusson \& Frikken, 2003; } \\
\text { Miller \& Gray, 1997; Prendergast, 2007) regarded } \\
\text { this terrane as a subduction complex, but Glen et } \\
\text { al. (2004) suggested it formed as an ocean-floor } \\
\text { sequence on the paleo-Pacific plate. } \\
\text { Subsequently, Glen (2013) adopted the } \\
\text { suggestion of C. Quinn (pers. comm.) that it was }\end{array}$ \\
\hline
\end{tabular}

URL: http://mc.manuscriptcentral.com/taje 


\begin{tabular}{|l|l|l|}
\hline & & $\begin{array}{l}\text { more likely to have formed the floor of a deep } \\
\text { basin on the outboard margin of Gondwana. } \\
\text { Geochemistry of these cherts and those in the } \\
\text { turbidites to the west were discussed by Bruce } \\
\text { and Percival (2014). }\end{array}$ \\
\hline $\begin{array}{l}\text { Igneous ocean crust } \\
\text { (Glen, 2005, 2013). }\end{array}$ & $\begin{array}{l}\text { Consists of variably serpentinised ultramafics, MORB-like tholeitic volcanics and } \\
\text { associated sedimentary rocks in southern (Coolac-Tumut region) and } \\
\text { northwestern NSW (e.g. Mt Dijou, Tottenham, and Girilambone associated with } \\
\text { Hermidale Terrane) }\end{array}$ & \\
\hline $\begin{array}{l}\text { Waratah Bay Terrane } \\
\text { (Glen et al., 2009). }\end{array}$ & $\begin{array}{l}\text { Shallow-water Digger Island Limestone in central Victoria (VandenBerg et al., } \\
\text { 2000) deposited on the basement Selwyn Block of Cayley et al. (2002). }\end{array}$ & \\
\hline
\end{tabular}


Table 2. Summary of $\mathrm{U}-\mathrm{Pb}, \varepsilon_{\mathrm{Hf}}$ and model age data.

\begin{tabular}{|c|c|c|c|c|c|c|c|c|}
\hline \multirow[b]{2}{*}{ Sample and age } & \multirow[b]{2}{*}{$\begin{array}{l}\text { Ma between } \\
\text { minimum } \\
\text { deposition } \\
\text { age and } \\
\text { youngest } \\
\text { peak }\end{array}$} & \multicolumn{3}{|c|}{ U-Pb AGE FEATURE } & \multicolumn{3}{|c|}{$\varepsilon \mathrm{Hf}-\mathrm{CLUSTER}$ DATA } & \multirow[b]{2}{*}{$\begin{array}{l}T_{\mathrm{DM}} \mathbf{C} \\
\text { Peak; approx. } \\
\text { spread to } 1 \\
\text { decimal point } \\
(\mathrm{Ga})\end{array}$} \\
\hline & & $\begin{array}{l}\text { Key feature } \\
\text { age (Ma) }\end{array}$ & $\begin{array}{l}\text { Late Panafrican age } \\
\text { Age range, peaks, } \\
\text { means (in bold); } \\
\text { internal groupings } \\
\text { (Ma) }\end{array}$ & $\begin{array}{l}\text { Late Grenvillian age } \\
\text { Age range, peaks, } \\
\text { means (in bold); } \\
\text { internal groupings } \\
(\mathrm{Ma})\end{array}$ & $\begin{array}{l}\text { Cluster } \\
\text { number }\end{array}$ & $\begin{array}{l}\text { Age range of } \\
\text { cluster (Ma) }\end{array}$ & $\begin{array}{l}\text { Approx. } \varepsilon \mathrm{Hf} \\
\text { range }\end{array}$ & \\
\hline $\begin{array}{l}\text { Bilpa } \\
\text { Conglomerate }\end{array}$ & & & Peak 501 & & & & & \\
\hline $\begin{array}{l}\text { Scropes Range } \\
\text { Formation } \\
06 \mathrm{E} 1 \\
482-491 \mathrm{Ma}\end{array}$ & 23 & \begin{tabular}{|l}
1180 \\
population, \\
very few \\
$1000-1100$ \\
\end{tabular} & $\begin{array}{l}490-600 \\
\text { Peaks } 562 \gg 588>510 \\
\text { Mean } \mathbf{5 1 4} \pm \mathbf{5}\end{array}$ & $\begin{array}{l}1060-1260 \\
\text { Peak } 1180 \\
\text { Mean } 1174 \pm 6\end{array}$ & 1 & $1120-1200$ & 0 to 2 & $2.0,1.9-2.2$ \\
\hline $\begin{array}{l}\text { Scropes Range } \\
\text { Formation }\end{array}$ & & & & & 2 & $1110-1240$ & 2 to 6.4 & $1.7,1.6-1.8$ \\
\hline $\begin{array}{l}\text { Scropes Range } \\
\text { Formation }\end{array}$ & & & & & 3 & $640-720$ & 6 to 8 & $1.19,1.1-1.4$ \\
\hline $\begin{array}{l}\text { Scropes Range } \\
\text { Formation }\end{array}$ & & & & & 4 & $510-620$ & -6.5 to 1 & $1.62,1.3-2$ \\
\hline $\begin{array}{l}\text { Scropes Range } \\
\text { Formation }\end{array}$ & & & & & 5 & $505-514$ & -10.5 to -9 & $2.05,1.9-2.15$ \\
\hline $\begin{array}{l}\text { Yandaminta } \\
476-482,606 \mathrm{Ma}\end{array}$ & 13 & $\begin{array}{l}1180 \mathrm{Ma} \\
\text { population, } \\
\text { very few } \\
1000-1100 \\
\mathrm{Ma}\end{array}$ & $\begin{array}{l}480-600 \\
\text { Peaks } 512 \gg 587 \\
\text { shoulder } 498 \\
\text { Mean } \mathbf{4 9 5} \pm \mathbf{5}, \mathbf{5 1 4} \pm \mathbf{5}\end{array}$ & $\begin{array}{l}1000-1300 \\
\text { Peak } 1172 \gg 1090 \\
\text { Mean } 1172 \pm 7\end{array}$ & 1 & $1075-1200$ & -5.5 to 0 & 2.02, 1.9-2.3, \\
\hline Yandaminta & & \begin{tabular}{|l|l}
+2 \\
\end{tabular} & 8 & & 2 & $1160-1230$ & 2.5 to 7.5 & $1.65,1.5-1.8$ \\
\hline Yandaminta & & & 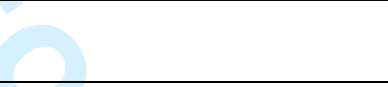 & & 3 & $650-700$ & 2.6 to 6.5 & $\begin{array}{l}\text { 1.45, 1.4-1.5, } \\
1.1-1.2 \\
\end{array}$ \\
\hline Yandaminta & & $\begin{array}{l}\text { peak 512, } \\
\text { means 514, } \\
495 \\
\end{array}$ & $P_{202}$ & & 4 & $490-600$ & -10.2 to -2.5 & $1.85,1.6-2.2$ \\
\hline Yandaminta & & \begin{tabular}{|l|} 
peak 1660, \\
range $1550-$ \\
1800 \\
\end{tabular} & & & & & -2.8 to 9.4 & \\
\hline $\begin{array}{l}\text { Castlemaine } \\
\text { Group Ben2 } \\
475-482 \mathrm{Ma}\end{array}$ & 5 & \begin{tabular}{|l|} 
Late \\
Panafrican \\
pop. most \\
constant of all \\
turbidite \\
samples. \\
Pinjarra \\
different \\
\end{tabular} & $\begin{array}{l}480-600 \\
\text { Peaks 488>544>578 } \\
\text { Means 487 } \mathbf{4}, \mathbf{5 4 5} \pm \\
\mathbf{4} \\
14 @ 525-590,3 @ \\
585,2 @ 570\end{array}$ & $\begin{array}{l}900-1050 \\
\text { Peaks } 944=1046 \\
\text { Mean } 1044 \pm 10 \\
1 \text { grain @ 900, } 3 @ \\
940,6 @ 1020-1060\end{array}$ & 1 & $900-1050$ & 3.4 to 10.1 & $1.44,1.1-1.7$ \\
\hline Ben2 & & & & 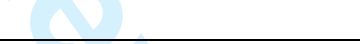 & 2 & $490-620$ & -1 to 2.5 & $1.45,1.4-1.6$ \\
\hline Ben2 & & & & +2 & 3 & $485-590$ & -4 to -2 & $1.65,1.6-1.8$ \\
\hline $\begin{array}{l}\text { Castlemaine } \\
\text { Group Ben5 } \\
\text { ca } 475 \mathrm{Ma}\end{array}$ & 15 & \begin{tabular}{|l|} 
Late \\
Panafrican \\
pop. most \\
constant of all \\
turbidite \\
samples. \\
Pinjarra \\
different \\
\end{tabular} & $\begin{array}{l}490-660 \\
\text { Peaks } 545 \gg 609>494 \\
\text { Means } 490 \pm \mathbf{5}, 552 \pm \\
\mathbf{3} \\
20 @ 560-520\end{array}$ & $\begin{array}{l}1000-1150 \\
\text { Peaks 1026, } 1065 \\
\text { Means 1015 } \pm 11 \\
1062 \pm 13 \\
3 @ 1060\end{array}$ & 1 & $970-1050$ & 4 to 9 & $1.41,1.3-1.7$ \\
\hline Ben5 & & & & & 2 & $810-920$ & 3.5 to 5.5 & $1.42,1.3-1.5$ \\
\hline Ben5 & & & & & 3 & $530-660$ & -1 to 5 & $1.38,1.2-1.6$ \\
\hline Ben5 & & & & & 4 & $530-610$ & -5.5 to -2.4 & $1.72,1.6-1.9$ \\
\hline Ben5 & & & & & 5 & $530-610$ & -14 to -9.8 & $2.16,2.1-2.3$ \\
\hline $\begin{array}{l}\text { Castlemaine } \\
\text { Group Cob1 } \\
461-463 \mathrm{Ma}\end{array}$ & 28 & \begin{tabular}{|l} 
Late \\
Panafrican \\
pop. most \\
constant of all \\
turbidite \\
samples. \\
Pinjarra \\
different \\
\end{tabular} & $\begin{array}{l}479-680 \\
\text { Peaks } 552 \gg>490= \\
617 \text { Means } 493 \pm 6 \\
552 \pm 3 \\
4 @ 479-500,5 @ \\
525,22 @ 530-595,6 \\
@ 600-650\end{array}$ & $\begin{array}{l}10 @ 950-1100 \\
\text { Peak } 1075 \\
\text { Mean } 1078 \pm 9\end{array}$ & 1 & 1720-1800 & 1.4 to 3.5 & $2.27,2.2-2.3$ \\
\hline Cob1 & & & & & 2 & $950-1100$ & 3.9 to 7.2 & $1.5,1.4-1.6$ \\
\hline Cob1 & & & & & 3 & $550-640$ & -2.4 to 3 & $1.5,1.4-1.7$ \\
\hline Cob1 & & & & & 4 & $490-580$ & -6 to -3 & $1.73,1.7-1.8$ \\
\hline Cob1 & & & & & 5 & $1726-1737$ & $\begin{array}{c}-3.83 \text { to }- \\
2.11 \\
\end{array}$ & $2.6,2.5-2.7$ \\
\hline Cob1 & & & & & 6 & $1075-1087$ & 1.74 to 1.83 & $1.78,1.7-1.9$ \\
\hline Cob1 & & & & & 7 & $594-606$ & $\begin{array}{c}-14.96 \text { to }- \\
13.71 \\
\end{array}$ & $2.39,2.3-2.5$ \\
\hline $\begin{array}{l}\text { Girilambone } \\
\text { Group Mwb1 } \\
\text { ca } 484 \mathrm{Ma}\end{array}$ & & $\begin{array}{l}\text { mean at } \\
2445 \pm 33\end{array}$ & $\begin{array}{l}\text { unimodal peak at } 497 \\
\text { Mean at } 495 \pm 5\end{array}$ & minor & & & & \\
\hline $\begin{array}{l}\text { Girilambone } \\
\text { Group TrittonNE } \\
\text { ca } 484 \mathrm{Ma}\end{array}$ & & $\begin{array}{l}\text { mean at } \\
2271 \pm 22\end{array}$ & $\begin{array}{l}490-600 \\
\text { Peaks at } 497>575 \\
\text { Means at } \mathbf{5 0 1} \pm \mathbf{5 ,}, \mathbf{5 7 7} \\
\pm \mathbf{6}\end{array}$ & $\begin{array}{l}\text { minor, scattered } \\
\text { between } 900-1200\end{array}$ & & & & \\
\hline $\begin{array}{l}\text { Girilambone } \\
\text { Group Te2 } \\
\text { 475-485 Ma }\end{array}$ & $? 6$ & & $\begin{array}{l}470-600 \\
\text { Peaks } 553>507>472 \\
\text { Means } 555 \pm 5,472 \pm \\
7 \\
16 @ 490-600,3 @ \\
\text { ca } 580\end{array}$ & $\begin{array}{l}20 @ 1000-1200 \\
\text { Peaks } 1041>1153 \\
\text { Means } 1020 \pm 7 \\
1052 \pm 9 \\
5 @ 1000-1100\end{array}$ & 1 & 1080-1180 & -1.5 to 0 & $1.98,1.9-2.1$ \\
\hline Te2 & & $\begin{array}{l}\text { mean at } \\
2298 \pm 10 \\
\end{array}$ & & & 2 & $1020-1080$ & 2.5 to 10 & $1.56,1.2-1.7$ \\
\hline Te2 & & & & & 3 & $860-930$ & 3 to 4 & 1.55, 1.4-1.5, \\
\hline
\end{tabular}




\begin{tabular}{|c|c|c|c|c|c|c|c|c|}
\hline & & & & & & & & $1.6-1.7$ \\
\hline Te2 & & & & & 4 & $470-590$ & -1.5 to 2.6 & $1.44,1.3-1.6$ \\
\hline Te2 & & & & & 5 & $490-560$ & -5 to -3 & $1.68,1.6-1.8$ \\
\hline $\begin{array}{l}\text { Girilambone } \\
\text { Group Oggyc1 } \\
463-461 \mathrm{Ma}\end{array}$ & 1 & & $\begin{array}{l}\text { Peaks } 580>552=493 \\
=564>466 \\
\text { Means } 464 \pm \mathbf{7}, \mathbf{4 9 1} \pm \\
\mathbf{5}, \mathbf{5 2 1} \pm \mathbf{6}, \mathbf{5 7 9} \pm \mathbf{5} \\
2 @ \text { ca } 465,5 \text { 500- } \\
4490,17 @ 520-600 \\
\text { incl } 4 @ \text { ca } 520,6 @ \\
\text { ca } 580\end{array}$ & $\begin{array}{l}985-1090 \\
\text { Peaks } \\
1068>1003>1120 \\
\text { Mean } 1065 \pm 10 \\
2 @ 1000,5 @ c a \\
1060,3 @ \text { ca } 1120\end{array}$ & 1 & $480-600$ & -19 to -16 & $2.52,2.5-2.6$ \\
\hline Oggyc1 & & & & & 2 & $490-600$ & -13 to -6 & $1.96,1.8-2.3$ \\
\hline Oggyc1 & & & & & 3 & $1000-1010$ & -10.5 to -9 & $\begin{array}{l}2.44,2.4-2.5 \\
2.7-2.8\end{array}$ \\
\hline Oggyc1 & & & & & 4 & $800-1000$ & -6 to -2.5 & $2.02,1.9-2.1$ \\
\hline Oggyc1 & & & & & 5 & $480-620$ & -3.5 to 0 & $1.55,1.5-1.7$ \\
\hline Oggyc1 & & & & & 6 & $1000-1100$ & 5 to 9 & $\begin{array}{l}1.42,1.3-1.5 \\
1.6-1.7\end{array}$ \\
\hline Oggyc1 & & & & & 7 & $1060-1180$ & -2.5 to 0 & $\begin{array}{l}\mathbf{2 . 0}, 1.8-1.9, \\
2-2.2\end{array}$ \\
\hline Oggyc1 & & & & & 8 & $540-600$ & -24 to -22 & $2.86,2.8-3$ \\
\hline $\begin{array}{l}\text { Wagga Group } \\
\text { Oww5 } \\
472-475 \mathrm{Ma}\end{array}$ & 26 & & $\begin{array}{l}492-660 \\
\text { Peaks } 501>508>578 \\
\text { Mean } 500 \pm 5,530 \pm 9 \\
13 @<542 \text {, incl. } 6 @ \\
490-510,5 @ \text { ca } 530 \\
3 @ \text { ca } 580\end{array}$ & $\begin{array}{l}950-1250 \\
\text { Peaks } \\
993>1015>1109, \\
1180 \\
\text { Mean } 1000 \pm 13 \\
15 @ 950-1140,3 @ \\
1150-1200\end{array}$ & 1 & $970-1050$ & 0 to 3.5 & $1.68,1.6-1.8$ \\
\hline Oww5 & & $\nabla$ & & & 2 & $990-1130$ & 6 to 9 & $1.41,1.2-1.5$ \\
\hline Oww5 & & & 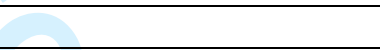 & & 3 & $520-660$ & -2 to 2.5 & $1.44,1.4-1.5$ \\
\hline Oww5 & & & 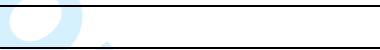 & & 4 & $490-610$ & -5 to -2 & $1.72,1.6-1.9$ \\
\hline Oww5 & & & 2 & & 5 & $490-550$ & -8 to -5 & $1.85,1.8-1.9$ \\
\hline $\begin{array}{l}\text { Wagga Group } \\
\text { Oww3 } \\
461-463 \mathrm{Ma}\end{array}$ & 4 & $\begin{array}{l}\text { spread of } \\
\text { ages from } \\
468-1050\end{array}$ & $\begin{array}{l}468-600 \\
\text { Peaks } \\
531 / 546>587>467 \\
2 @ 530,2 @ 550,4 \\
@ 580-620(3 @ c a \\
605), 4 @ 681-700\end{array}$ & $\begin{array}{l}\text { Peak } 1037 \\
\text { Mean } 1040 \pm 9 \\
4 @ 1000-1050\end{array}$ & 1 & $1060-1130$ & 5 to 11 & $1.4,1.2-1.6$ \\
\hline Oww3 & & & av & & 2 & $900-960$ & $7.5,4.4$ & $\begin{array}{l}1.28,1.2-1.3, \\
1.5\end{array}$ \\
\hline Oww3 & & & $V$ & & 3 & 790-910 & -2.5 to -0.5 & $1.78,1.7,1.9$ \\
\hline Oww3 & & & & 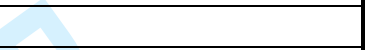 & 4 & $530-620$ & -1 to 5.5 & $1.35,1.2-1.4$ \\
\hline Oww3 & & & 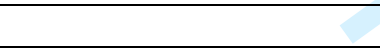 & +2 & 5 & $680-710$ & -5 to 0 & $1.76,1.5-2$ \\
\hline Oww3 & & & & & 6 & $550-620$ & -4 to 0 & $\begin{array}{l}1.60,1.5-1.6 \\
1.7-1.8\end{array}$ \\
\hline $\begin{array}{l}\text { Adaminaby Group } \\
\text { Mum1 491-482 } \\
\text { Ma }\end{array}$ & 1 & $\begin{array}{l}\text { trimodal } \\
\text { peaks }\end{array}$ & $\begin{array}{l}600-480 \\
\text { Peaks 578,490>540. } \\
\text { Mean } 579 \pm 7 \\
6 @ 520-480,4 @ \text { ca } \\
540,4 @ \text { ca } 580\end{array}$ & $\begin{array}{l}1060-990 \\
\text { Peak } 1044 \\
\text { Mean=1044 +1 } \\
2 @ 1020-990,4 @ \\
1055-1030\end{array}$ & & & & \\
\hline $\begin{array}{l}\text { Adaminaby Group } \\
\text { Bun8 } \\
482-475 \mathrm{Ma}\end{array}$ & 22 & & $\begin{array}{l}600-500 \\
\text { Peaks } 540 \gg>560, \\
504 . \\
\text { Means } 505 \pm \mathbf{8}, \mathbf{5 2 6} \pm \\
7, \mathbf{5 4 2} \pm 5,567 \pm 12 \\
2 @ \text { ca } 505,3 \text { @ 533- } \\
520,6 @ 546-539,6 \\
@ 590-554 .\end{array}$ & $\begin{array}{l}1200-950 \\
\text { Peaks } \\
1019>956,1082, \\
1193 . \\
\text { Means } 1024 \pm 11 \\
1093 \pm 35,1194 \pm 42 \\
4 @ 1000-950,4 @ \\
1035-1020,3 @ c a \\
1090,3 @ \text { ca } 1194 \\
\end{array}$ & 1 & $1100-950$ & -1 to 3 & $1.76,1.7-1.9$ \\
\hline Bun8 & & & & & 2 & 1050-950 & 5 to 9 & $1.44,1.3-1.6$ \\
\hline Bun8 & & & & & 3 & $700-550$ & 0 to 4 & $1.46,1.2-1.6$ \\
\hline Bun8 & & & & & 4 & $550-490$ & 4 to 5 & $1.17,1.2$ \\
\hline Bun8 & & & & & 5 & $600-500$ & -5 to 0 & $1.57,1.4-1.7$ \\
\hline Bun8 & & & & & 6 & $580-490$ & -8 to -5 & $1.86,1.8-1.9$ \\
\hline $\begin{array}{l}\text { Adaminaby Group } \\
\text { Bun9 } \\
475-482 \mathrm{Ma}\end{array}$ & 41 & & $\begin{array}{l}500-650 \\
\text { Peaks } 557>>523>624 \\
609 . \\
\text { Mean } 557 \pm 7 \\
2 @ 609,625,8<600 \\
\text { incl } 1 @ 520,1 @ 526 \\
1 @ 540,4 @ \text { ca } 555\end{array}$ & $\begin{array}{l}3 @ 1063-1078 \\
\text { Peak } 1070 \\
\text { Mean } 1070 \pm 13\end{array}$ & 1 & $520-625$ & -4 to 0 & $\begin{array}{l}1.62,1.4-1.8 \\
1.9-2\end{array}$ \\
\hline Bun9 & & & & & & 256 & -0.75 & 1.3 \\
\hline Bun9 & & & & & & 272 & 4.46 & 1 \\
\hline $\begin{array}{l}\text { Adaminaby Group } \\
\text { Bun4 } \\
461-463 \mathrm{Ma}\end{array}$ & 44 & & $\begin{array}{l}500-620 \\
\text { Peaks 589>568>505. } \\
\text { Means } 560 \pm \mathbf{1 5}, \mathbf{5 8 0} \\
\pm \mathbf{5} \\
2 \text { @ 502; } 3 @ 510- \\
520 ; 2 @ 535,541 ; 2 \\
@ 555,557 ; 13 @ \\
565-600\end{array}$ & $\begin{array}{l}1000-1150 \\
\text { Peaks } \\
1023>1086>1229 \\
3 @ c a 1015,3 @ c a \\
1100,2 @ 1150- \\
1250\end{array}$ & 1 & $820-1050$ & 4.5 to 7.5 & $1.4,1.3-1.5$ \\
\hline Bun4 & & & & & 2 & $840-900$ & 0 to 3 & $1.64,1.5-1.8$ \\
\hline Bun4 & & & & & 3 & $550-600$ & -1.5 to 3 & $\begin{array}{l}1.50,1.3-1.4 \\
1.6\end{array}$ \\
\hline Bun4 & & & & & 4 & $550-610$ & -5.5 to -3 & $1.75,1.7-1.9$ \\
\hline Bun4 & & & & & 5 & $480-590$ & -10 to -6 & $1.94,1.9-2.1$ \\
\hline Bun4 & & & & & 6 & $510-620$ & -21 to -18 & $2.68,2.6-2.9$ \\
\hline
\end{tabular}


Table 3. Possible source regions in Australia

\begin{tabular}{|c|c|c|c|c|c|c|c|}
\hline $\begin{array}{l}\text { Tectonic } \\
\text { unit }\end{array}$ & $\begin{array}{l}\text { Units/ } \\
\text { lithology }\end{array}$ & & U-Pb zircon/ whole rock (Ma) & Ar-Ar mica & $\begin{array}{l}\varepsilon H f / \varepsilon N d \\
\left(\varepsilon H f=\varepsilon_{N d}(i) \times 1.83+0.60\right)\end{array}$ & $\begin{array}{l}T_{\mathrm{DM}} \text { model } \\
\text { age (Ga) }\end{array}$ & References \\
\hline $\begin{array}{l}\text { Delamerian } \\
\text { Orogen }\end{array}$ & $\begin{array}{l}\text { South } \\
\text { Australian } \\
\text { granites }\end{array}$ & $\begin{array}{l}\text { Rathjen } \\
\text { Gneiss }\end{array}$ & $\begin{array}{l}514 \text {, cores ca 2500, 1950- } \\
2200 \text {, ca 1280, 900-1000, } \\
550-675\end{array}$ & & $\begin{array}{l}\varepsilon_{\mathrm{Nd}}(\mathrm{i}) \text { of }-6.2 \\
\left(\varepsilon_{\mathrm{Hf}}-10.8\right)\end{array}$ & 1.6 & $\begin{array}{l}\text { Foden et al. } \\
\text { (1999) }\end{array}$ \\
\hline $\begin{array}{l}\text { Delamerian } \\
\text { Orogen }\end{array}$ & $\begin{array}{l}\text { South } \\
\text { Australian } \\
\text { granites }\end{array}$ & $\begin{array}{l}\text { S-type } \\
\text { granites }\end{array}$ & & & $\begin{array}{l}\varepsilon_{\mathrm{Nd}}(\mathrm{i})-13.7 \text { to }-8.4 \text {, mainly }- \\
13.7 \text { to }-11 ; \\
\left(\varepsilon_{\mathrm{Hf}}-24.5 \text { to }-14.8, \varepsilon_{\mathrm{Hf}}\right. \\
\text { mainly }-24.5 \text { to }-19.5)\end{array}$ & & $\begin{array}{l}\text { Foden et al. } \\
(2002)\end{array}$ \\
\hline $\begin{array}{l}\text { Delamerian } \\
\text { Orogen }\end{array}$ & $\begin{array}{l}\text { South } \\
\text { Australian } \\
\text { granites }\end{array}$ & I-type granites & & & $\begin{array}{l}\varepsilon_{\mathrm{Nd}}(\mathrm{i})-10.5 \text { to }+1.8, \text { mainly }- \\
6 \text { to }-2 \\
\left(\varepsilon_{\mathrm{Hf}}+3.9 \text { to }-18.6\right. \\
\left.\varepsilon_{\mathrm{Hf}} \text { mainly }-10.4 \text { to }-3.1\right)\end{array}$ & & $\begin{array}{l}\text { Foden et al. } \\
(2002)\end{array}$ \\
\hline $\begin{array}{l}\text { Delamerian } \\
\text { Orogen }\end{array}$ & $\begin{array}{l}\text { South } \\
\text { Australian } \\
\text { granites }\end{array}$ & I-S granites & & & $\begin{array}{l}\varepsilon_{\mathrm{Nd}}(\mathrm{i})-2.3,-12.8 \text { to }-12.0 \\
\text { (mainly } \varepsilon_{\mathrm{Hf}}-22.8 \text { to }-21.4 \text { ) }\end{array}$ & & $\begin{array}{l}\text { Foden et al. } \\
(2002)\end{array}$ \\
\hline $\begin{array}{l}\text { Delamerian } \\
\text { Orogen }\end{array}$ & $\begin{array}{l}\text { Victorian } \\
\text { granites }\end{array}$ & I-type granites & $515 \mathrm{Ma}$ & & $\begin{array}{l}\varepsilon_{\mathrm{Nd}}(\mathrm{i})-8.85 \text { and }-4.14 \\
\left(\varepsilon_{\mathrm{Hf}}-15.60 \text { and }-6.72\right) \\
\varepsilon_{\mathrm{Hf}}+1.9 \pm 1.31\end{array}$ & & $\begin{array}{l}\text { Kemp et al. } \\
(2009)\end{array}$ \\
\hline $\begin{array}{l}\text { Delamerian } \\
\text { Orogen }\end{array}$ & $\begin{array}{l}\text { Victorian } \\
\text { granites }\end{array}$ & I-type granites & $510 \mathrm{Ma}$ & 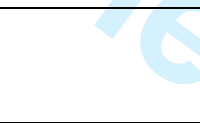 & $\begin{array}{l}\varepsilon_{\mathrm{Nd}}(\mathrm{t})-6.44 \text { to }-5.13 \\
\left(\varepsilon_{\mathrm{Hf}}-11.19 \text { to }-8.79\right) \\
\varepsilon_{\mathrm{Hf}}-3.33 \pm 1.91\end{array}$ & & $\begin{array}{l}\text { Kemp et al. } \\
(2009)\end{array}$ \\
\hline $\begin{array}{l}\text { Delamerian } \\
\text { Orogen }\end{array}$ & $\begin{array}{l}\text { Victorian } \\
\text { granites }\end{array}$ & I-type granites & $500 \mathrm{Ma}$ & & $\begin{array}{l}\varepsilon_{\mathrm{Nd}}(\mathrm{t})-11.68 \text { to }-5.13 \\
\left(\varepsilon_{\mathrm{Hf}}-20.78 \text { to }-8.79\right)\end{array}$ & & $\begin{array}{l}\text { Kemp et al. } \\
\text { (2009) }\end{array}$ \\
\hline $\begin{array}{l}\text { Delamerian } \\
\text { Orogen }\end{array}$ & $\begin{array}{l}\text { Victorian } \\
\text { granites }\end{array}$ & I-type granites & $495 \mathrm{Ma}$ & & $\begin{array}{l}\varepsilon_{\mathrm{Nd}}(\mathrm{t})-4.51 \text { to }-2.74 \\
\left(\varepsilon_{\mathrm{Hf}}-7.65 \text { to }-4.41\right)\end{array}$ & & $\begin{array}{l}\text { Kemp et al. } \\
(2009)\end{array}$ \\
\hline $\begin{array}{l}\text { Delamerian } \\
\text { Orogen }\end{array}$ & $\begin{array}{l}\text { Victorian } \\
\text { granites }\end{array}$ & $\begin{array}{l}\text { S-type } \\
\text { granites }\end{array}$ & $500 \mathrm{Ma}$ & & $\begin{array}{l}\varepsilon_{\mathrm{Nd}}(\mathrm{t})-9.78 \text { to }-8.53 \\
\left(\varepsilon_{\mathrm{Hf}}-17.29 \text { to }-15.01\right)\end{array}$ & & $\begin{array}{l}\text { Kemp et al. } \\
(2009)\end{array}$ \\
\hline $\begin{array}{l}\text { Delamerian } \\
\text { Orogen }\end{array}$ & $\begin{array}{l}\text { Victorian } \\
\text { granites }\end{array}$ & I-S granite & $500 \mathrm{Ma}$ & & $\varepsilon_{\mathrm{Hf}}-6.03 \pm 1.03$ & & $\begin{array}{l}\text { Kemp et al. } \\
(2009)\end{array}$ \\
\hline $\begin{array}{l}\text { Delamerian } \\
\text { Orogen }\end{array}$ & $\begin{array}{l}\text { Kanmantoo } \\
\text { Group } \\
\text { sandstone }\end{array}$ & & & & $\begin{array}{l}\varepsilon_{\mathrm{Nd}}(\mathrm{t})-16 \text { to }-9.2(4 \text { grains } \\
\text { less negative than }-10) \\
\varepsilon_{\mathrm{Hf}}-29 \text { to }-16.4\end{array}$ & $\begin{array}{l}\text { lower part } \\
1.8-2, \text { upper } \\
\text { part } 2-2.2\end{array}$ & $\begin{array}{l}\text { Haines et al. } \\
(2009)\end{array}$ \\
\hline $\begin{array}{l}\text { Delamerian } \\
\text { Orogen }\end{array}$ & $\begin{array}{l}\text { Kanmantoo } \\
\text { Group }\end{array}$ & $\begin{array}{l}\text { Carrickalinga } \\
\text { Head } \\
\text { Formation }\end{array}$ & $\begin{array}{l}\text { ca 500-650, (peaks at 572, } \\
532), 1050-\text { broad }\end{array}$ & & & & $\begin{array}{l}\text { Ireland et al. } \\
(1998)\end{array}$ \\
\hline Delamerian & Kanmantoo & Carrickalinga & & ca 550-600 & & & Haines et al. \\
\hline
\end{tabular}




\begin{tabular}{|c|c|c|c|c|c|c|}
\hline Orogen & Group & $\begin{array}{l}\text { Head } \\
\text { Formation }\end{array}$ & & $\begin{array}{l}\text { peak, minor } \\
\text { ca } 950 \text { peak }\end{array}$ & & (2004) \\
\hline $\begin{array}{l}\text { Delamerian } \\
\text { Orogen }\end{array}$ & $\begin{array}{l}\text { Kanmantoo } \\
\text { Group }\end{array}$ & $\begin{array}{l}\text { Balquidder } \\
\text { Formation }\end{array}$ & $\begin{array}{l}500-600, \text { (peaks at } 587,546), \\
980-1250 \text { (small peaks at } \\
1163,1122,1071)\end{array}$ & $\begin{array}{l}\text { main peak } \\
550-600, \\
\text { minor peak ca } \\
950\end{array}$ & & $\begin{array}{l}\text { Ireland et al. } \\
\text { (1998) }\end{array}$ \\
\hline $\begin{array}{l}\text { Delamerian } \\
\text { Orogen }\end{array}$ & $\begin{array}{l}\text { West } \\
\text { Tasmania } \\
\text { granites }\end{array}$ & $\begin{array}{l}\text { S-type South } \\
\text { West Cape }\end{array}$ & $\begin{array}{l}497.8 \pm 3.3, \text { xenocrysts at } c a \\
1550-1860 \text { with peaks at } c a \\
1850-1800,1750,1680,1600 \\
\text { Populations at ca } 1720-1880 \\
1500-1700,1200-1450,900- \\
1100,600-800\end{array}$ & & & $\begin{array}{l}\text { Black et al. } \\
(2005,2010)\end{array}$ \\
\hline $\begin{array}{l}\text { Delamerian } \\
\text { Orogen }\end{array}$ & $\begin{array}{l}\text { West } \\
\text { Tasmania } \\
\text { granites }\end{array}$ & $\begin{array}{l}\text { I-type Elliot } \\
\text { Bay }\end{array}$ & $498.8 \pm 3.3$ & & & $\begin{array}{l}\text { Black et al. } \\
\text { (2005) }\end{array}$ \\
\hline $\begin{array}{l}\text { Delamerian } \\
\text { Orogen }\end{array}$ & $\begin{array}{l}\text { West } \\
\text { Tasmania } \\
\text { granites }\end{array}$ & $\begin{array}{l}\text { orthogneiss } \\
\text { offshore }\end{array}$ & 1050 & & & $\begin{array}{l}\text { Berry et al. } \\
(2008)\end{array}$ \\
\hline $\begin{array}{l}\text { Albany- } \\
\text { Fraser } \\
\text { Orogen } \\
\text { (WA) }\end{array}$ & Overview & & $\begin{array}{l}\text { Stage I } 1260-1345 \text {, Stage II } \\
1140-1215 . \text { Dykes at } 750 ; \\
\text { deformation at } 500-550 \text { on } \\
\text { SW margin }\end{array}$ & $\sqrt{3}$ & & $\begin{array}{l}\text { Clark et al. } \\
(2000) ; \\
\text { Fitzsimons } \\
(2003)\end{array}$ \\
\hline $\begin{array}{l}\text { Albany- } \\
\text { Fraser } \\
\text { Orogen } \\
\text { (WA) }\end{array}$ & Biranup Zone & & $\begin{array}{l}\text { 1) gneiss from } 2600-2700 \\
\text { granites } \\
\text { 2) gneiss \& gabbro at } 1600- \\
1700 \\
\text { 3) granite in stage I tectonism } \\
\text { at } 1300\end{array}$ & & $\begin{array}{l}2.7-2.8 \\
2.1-2.12\end{array}$ & $\begin{array}{l}\text { Fitzsimons } \\
(2003) \\
\text { Kirkland et al. } \\
(2011)\end{array}$ \\
\hline $\begin{array}{l}\text { Albany- } \\
\text { Fraser } \\
\text { Orogen } \\
\text { (WA) }\end{array}$ & Fraser Zone & & $\begin{array}{l}\text { 1) metamorphism, granite } \\
\text { gneiss, charnockite and } \\
\text { mafic intrusion } 1300 . \\
\text { 2) stage I tectonism, exhumed } \\
\text { by } 1250 . \\
\text { 3) stage II syntectonic } 1175 \\
\text { pegmatites }\end{array}$ & & $2.0-2.5$ & $\begin{array}{l}\text { Fitzsimons } \\
\text { (2003); Kirkland } \\
\text { et al. (2011) }\end{array}$ \\
\hline $\begin{array}{l}\text { Albany- } \\
\text { Fraser } \\
\text { Orogen } \\
\text { (WA) }\end{array}$ & $\begin{array}{l}\text { Nornalup } \\
\text { Zone }\end{array}$ & Fraser Belt & $\begin{array}{l}\text { 1) } 1280-1330 \text { granite intruding } \\
\text { basement gneiss with ca } \\
1560 \text { max dep. age and } \\
\text { detrital zircons } 2030-2750 \text {, } \\
1800,1560 \text { ) }\end{array}$ & & $\begin{array}{l}1.8-1.9 \\
2.26\end{array}$ & $\begin{array}{l}\text { Fitzsimons } \\
(2003) \\
\text { Kirkland et al. } \\
(2011)\end{array}$ \\
\hline
\end{tabular}




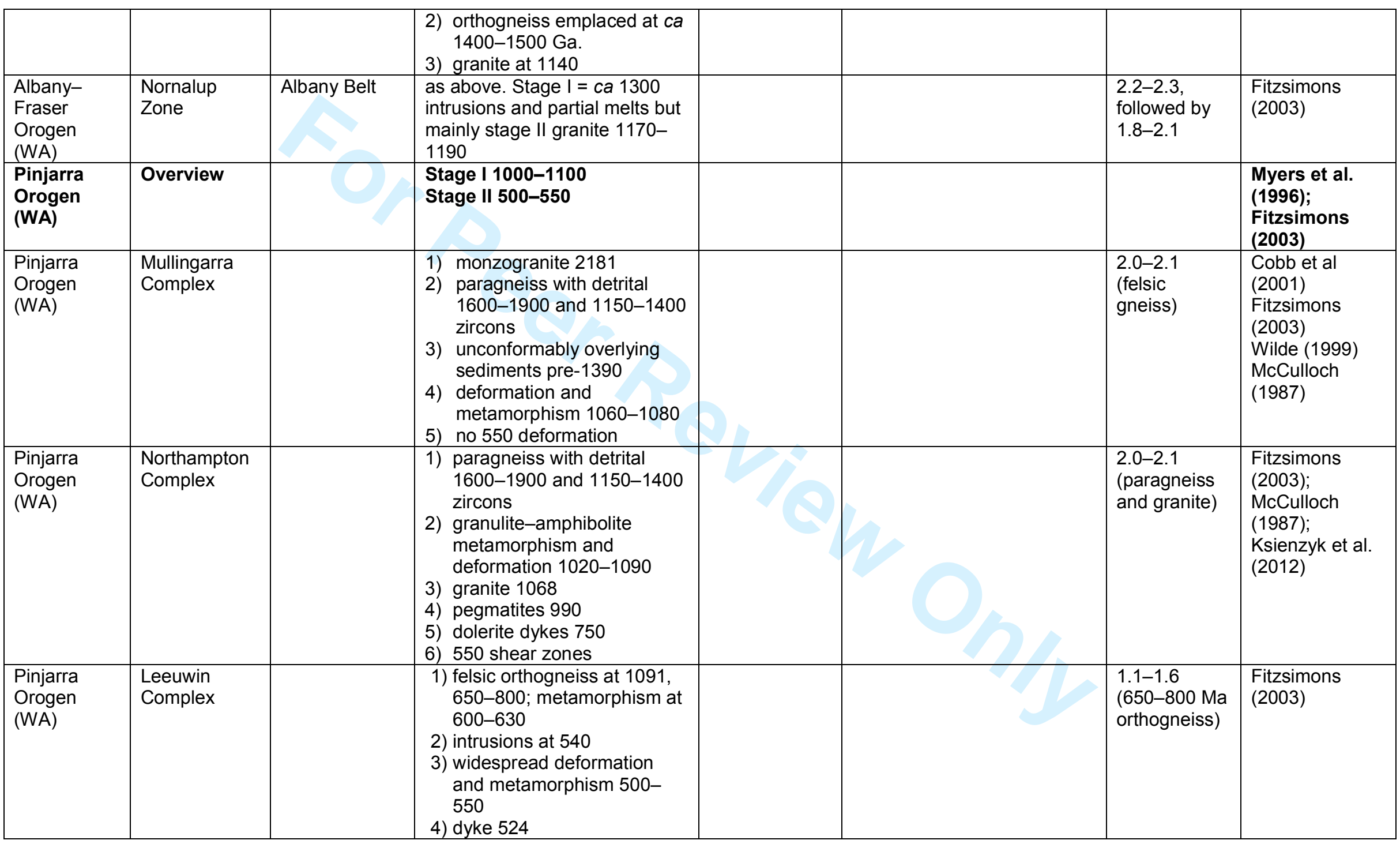


Table 4. Possible Antarctic source regions - I East Antarctic Shield.

\begin{tabular}{|c|c|c|c|c|c|c|}
\hline Tectonic unit & Units/ lithology & & U-Pb zircon/ whole rock (Ma) & $\begin{array}{l}\varepsilon_{\mathrm{Hf}}\left(\varepsilon_{\mathrm{Hf}}=\varepsilon_{\mathrm{Nd}}(i) \times 1.83+\right. \\
0.60\end{array}$ & $\begin{array}{l}\text { Model age } \\
\text { (Ga) }\end{array}$ & References \\
\hline \multirow[b]{2}{*}{$\begin{array}{l}\text { Albany-Fraser } \\
\text { Orogen } \\
\text { (Antarctica) }\end{array}$} & $\begin{array}{l}\text { Windmill Islands } \\
\text { G1 }\end{array}$ & & $\begin{array}{l}\text { 1) } \mathrm{M} 1 \text { partial melting felsic igneous } \\
1342 \\
\text { 2) D1 and syntect granites } 1315 \\
\text { 3) D2 orthogneiss } 1171-1214, \\
\text { granite, charnockite } 1173,1163 \\
\text { 4) post-tectonic aplite } 1138 \\
\text { 5) limited } 500\end{array}$ & $\begin{array}{l}\varepsilon_{\mathrm{Nd}}(\mathrm{t}) \text { mostly }-12 \text { to }-2 \\
\left(\varepsilon_{\mathrm{Hf}}-21.4 \text { to }-3.1\right)\end{array}$ & $1.9-3.2$ & $\begin{array}{l}\text { Fitzsimons } \\
\text { (2003); Möller } \\
\text { et al. (2002) }\end{array}$ \\
\hline & $\begin{array}{l}\text { Bunger Hills } \\
\text { G1 }\end{array}$ & & $\begin{array}{l}\text { 1) granite orthogneiss protoliths } \\
1521 \text { and ca } 1521 \text { and } 1699 \\
\text { 2) granulite facies deformation and } \\
\text { metamorphism } 1190 \\
\text { 3) intrusions } 1170 \text { and monzodiorite } \\
1151 \\
\text { 4) } 1140-1150 \text { Ma mafic dykes } \\
\text { 5) limited } 500 \text { deformation and } \\
\text { basalt dykes. }\end{array}$ & $\begin{array}{l}1-3) \varepsilon_{\mathrm{Nd}}(\mathrm{t})-3 \text { to }-15 \\
\left(\varepsilon_{\mathrm{Hf}}-26.9 \text { to }-4.9\right) \\
\text { 4) } \varepsilon_{\mathrm{Nd}}(\mathrm{t})-1 \text { to }+7 \\
\left(\varepsilon_{\mathrm{Hf}}-1.2 \text { to } 13.4\right)\end{array}$ & 1-3) $1.6-2.3$ & $\begin{array}{l}\text { Fitzsimons } \\
(2003) ; \\
\text { Sheraton et al. } \\
(1992)\end{array}$ \\
\hline \multirow{2}{*}{$\begin{array}{c}\text { Rayner } \\
\text { Complex } \\
\text { (Antarctica)) }\end{array}$} & $\begin{array}{l}\text { Beaver Terrane } \\
\text { G2 (northern } \\
\text { Prince Charles } \\
\text { Mountains) and } \\
\text { coastal regions }\end{array}$ & & $\begin{array}{l}\text { 1) dominantly felsic gneissic } \\
\text { protoliths } 1020-1400 \\
\text { 2) high metamorphism and felsic } \\
\text { magmatism } 900-990 \\
\text { 3) } 550 \text { dykes and } 517 \text { pegmatites }\end{array}$ & $\begin{array}{l}\varepsilon_{\mathrm{Nd}}(\mathrm{t})-10 \text { to }+1 \\
\left(\varepsilon_{\mathrm{Hf}}-17.7 \text { to }+2.43\right)\end{array}$ & $1.8-2.4$ & $\begin{array}{l}\text { Mikhalsky et } \\
\text { al. (2013) }\end{array}$ \\
\hline & Fisher Terrane G2 & & $\begin{array}{l}\text { 1) felsic to mafic intrusions and } \\
\text { volcanics } 1300-1400 \\
\text { 2) metamorphism and magmatism } \\
950-1210\end{array}$ & $\begin{array}{l}\varepsilon_{\mathrm{Nd}}(\mathrm{t}) 0 \text { to }+5 \\
\text { extremes }+5 \text { to }+10 \\
\left(\varepsilon_{\mathrm{Hf}} 0 \text { to }+9.75\right. \\
\text { extremes }+9.75 \text { to } \\
+18.9)\end{array}$ & $\begin{array}{l}1.6-2.0, \\
\text { extremes } 1.3- \\
1.4\end{array}$ & $\begin{array}{l}\text { Mikhalsky et } \\
\text { al. (2013) }\end{array}$ \\
\hline $\begin{array}{l}\text { Maud Belt } \\
\text { (Antarctica) }\end{array}$ & $\begin{array}{l}\text { Western Dronning } \\
\text { Maud Land G3 }\end{array}$ & & $\begin{array}{l}\text { 1) paragneiss with } 1100-1400 \\
\text { detrital zircon } \\
\text { 2) } 1100-1170 \text { mafic to felsic } \\
\text { volcanics } \\
\text { 3) } 1030-1100 \text { granitoid magmatism } \\
\text { and granulite metamorphism }\end{array}$ & $\begin{array}{l}\varepsilon_{\mathrm{Nd}}(\mathrm{t})-3.7 \text { to }+4.4 \\
\left(\varepsilon_{\mathrm{Hf}}-6.2 \text { to }+8.7\right)\end{array}$ & & $\begin{array}{l}\text { Arndt et al. } \\
(1991) ; \\
\text { Ksienzyk et al. } \\
(2015)\end{array}$ \\
\hline $\begin{array}{l}\text { Panafrican } \\
\text { belts } \\
\text { (Antarctica) } \\
\text { (extensions } \\
\text { of Pinjarra or }\end{array}$ & Overview & $\begin{array}{l}\text { Gneisses and } \\
\text { granitoids }\end{array}$ & $\begin{array}{l}\text { 1) local gneissic complexes with } \\
2100-3400 \text { protoliths (Ruker, } \\
\text { Lambert, Rauer, Vestfold, } \\
\text { Denman) } \\
\text { 2) } 900-1400 \text { Grenvillian }\end{array}$ & & & $\begin{array}{l}\text { Fitzsimons } \\
(2003) \text { Harley } \\
\text { \& Fitzsimons } \\
(2013)\end{array}$ \\
\hline
\end{tabular}




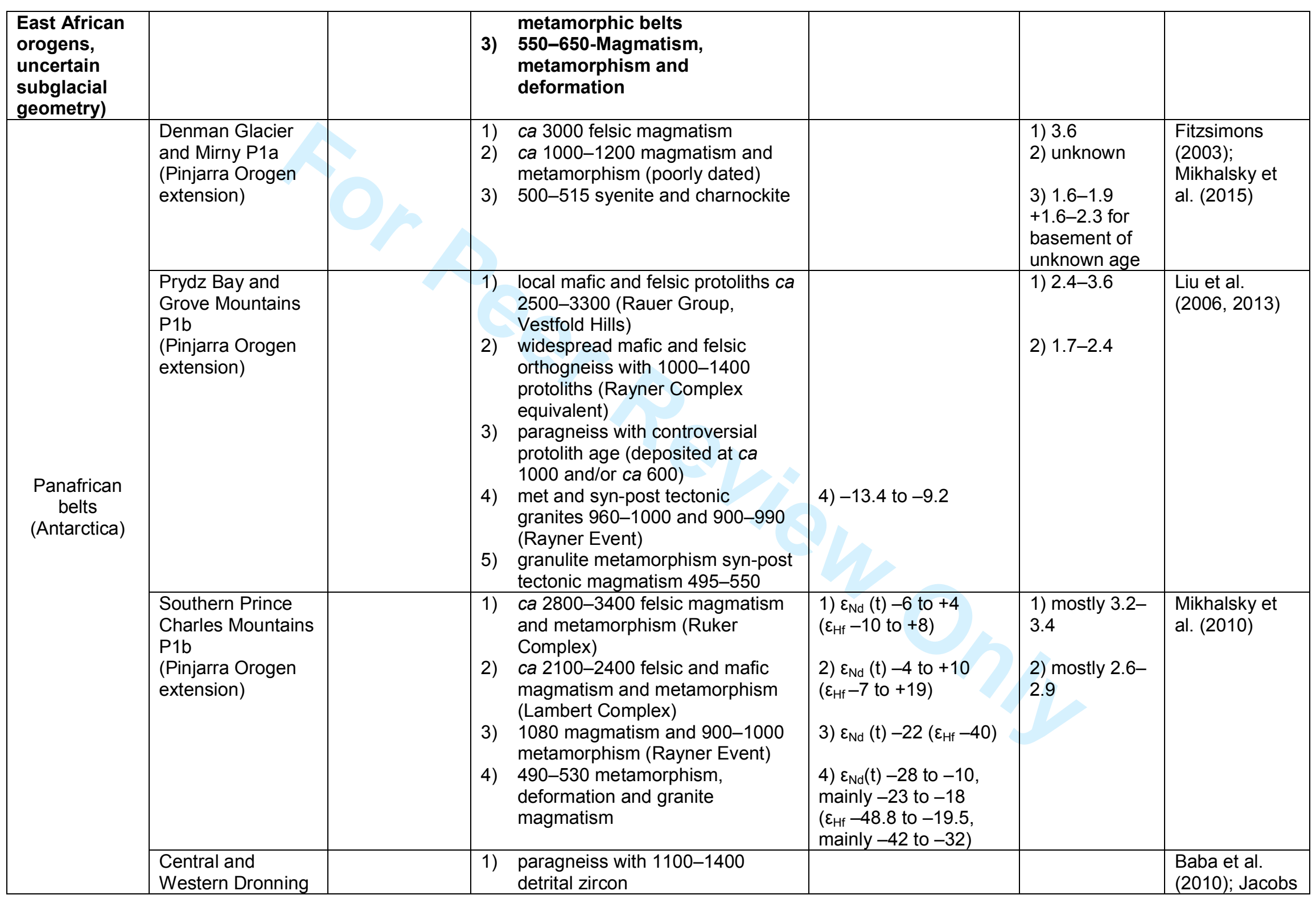




\begin{tabular}{|c|c|c|c|c|c|c|c|}
\hline & $\begin{array}{l}\text { Maud Land P2 } \\
\text { (East African } \\
\text { Orogen extension) }\end{array}$ & & $\begin{array}{l}\text { 2) } \\
\text { 3) } \\
\text { 4) } \\
\text { 5) } \\
\text { 6) } \\
\text { 7) }\end{array}$ & $\begin{array}{l}\text { orthogneisses with } 1100-1150 \\
\text { volcanic protoliths and ca } 1190 \\
\text { inherited zircons } \\
1060-1090 \text { metamorphism and } \\
\text { syntectonic granites } \\
\text { local ca } 650 \text { Ma metamorphism } \\
\text { and ca } 600 \text { charnockites and } \\
\text { anorthosites } \\
\text { deformation, metamorphism and } \\
\text { leucogranite intrusion } 500-550 \\
\text { deformation, metamorphism and } \\
\text { syntectonic granite } 525-530 \\
485-520 \text { post-tectonic granite }\end{array}$ & $\begin{array}{l}\text { 2) } \varepsilon_{\mathrm{Nd}}(\mathrm{t})-1 \text { to }+7 \\
\left(\varepsilon_{\mathrm{Hf}}-1 \text { to }+13\right) \\
\text { 7) } \varepsilon_{\mathrm{Nd}}(\mathrm{t})-19 \text { to }-1 \\
\left(\varepsilon_{\mathrm{Hf}}-1 \text { to }-34\right)\end{array}$ & $\begin{array}{l}\text { 2) } 1.02,1.34- \\
1.74 \\
\text { 7) } 1.2-1.7\end{array}$ & $\begin{array}{l}\text { et al. (1998, } \\
\text { 2003); Jacobs } \\
\text { 1999); Moyes } \\
\text { et al. (1993) }\end{array}$ \\
\hline & $\begin{array}{l}\text { Sør Rondane } \\
\text { Mountains and } \\
\text { adjacent nunataks } \\
\text { P2 } \\
\text { (East African } \\
\text { Orogen extension) }\end{array}$ & & $\begin{array}{l}\text { 1) } \\
\text { 2) } \\
\text { 3) } \\
\text { 4) } \\
\text { 5) }\end{array}$ & $\begin{array}{l}\text { 920-1015 gabbro-tonalite, } \\
\text { trondhjemite-granodiorite with } \\
1000-1070 \text { xenocrysts } \\
\text { local felsic magmatism ca } 800 \\
\text { paragneiss with } 680-3300 \text { detrital } \\
\text { zircons (mostly } 930-1190 \text { ) } \\
600-650 \text { granulite metamorphism } \\
\text { and magmatism } \\
500-590 \text { amphibolite } \\
\text { metamorphism and post-tectonic } \\
\text { granite }\end{array}$ & $\begin{array}{l}\text { 1) } \varepsilon_{\mathrm{Nd}}(\mathrm{t})-2 \text { to }+5 \\
\left(\varepsilon_{\mathrm{Hf}}-3.1 \text { to }+9.8\right) \\
4,5) \varepsilon_{\mathrm{Nd}}(\mathrm{t})-5 \text { to }+2 \\
\left(\varepsilon_{\mathrm{Hf}}-8.6 \text { to }+4.3\right)\end{array}$ & $\begin{array}{l}0.9-1.8 \\
(\text { mostly }<1.4)\end{array}$ & $\begin{array}{l}\text { Elburg et al. } \\
\text { (2015); Jacobs } \\
\text { et al. (2015); } \\
\text { Osanai et al. } \\
\text { (2013); } \\
\text { Shiraishi et al. } \\
\text { (2008) }\end{array}$ \\
\hline \multirow{3}{*}{$\begin{array}{l}\text { Subglacial } \\
\text { East } \\
\text { Antarctica } \\
\text { (inferred) }\end{array}$} & $\begin{array}{l}\text { Subglacial Terre } \\
\text { Adélie }\end{array}$ & $\begin{array}{l}\text { Detrital zircon } \\
\text { in offshore } \\
\text { Oligocene to } \\
\text { Pleistocene } \\
\text { turbidite }\end{array}$ & $\begin{array}{l}\text { 1) } \\
\text { 2) } \\
\text { 3) } \\
\text { 4) } \\
\text { 5) }\end{array}$ & $\begin{array}{l}\text { ca } 3510 \text {, ca } 3240 \text { (very small } \\
\text { populations) } \\
2650-2850,2200-2450 \text { (small } \\
\text { populations) } \\
1700-1780,1540-1660 \text {, ca } 1460 \\
\text { (major populations) } \\
760-1240 \text { (moderate populations) } \\
480-680 \text { (dominant population; } \\
\text { peak ca } 570 \text { ) }\end{array}$ & $\begin{array}{l}\text { 3) } \varepsilon_{\mathrm{Hf}}-4 \text { to }+9 \\
\text { 4) } \varepsilon_{\mathrm{Hf}}-2 \text { to }+11 \\
\text { 5) } \varepsilon_{\mathrm{Hf}}-40 \text { to }+9\end{array}$ & $\begin{array}{l}\text { 3) } 1.7-2.6 \\
\text { 4) } 1.4-2.1 \\
\text { 5) } 1.0-2.3\end{array}$ & $\begin{array}{l}\text { Veevers \& } \\
\text { Saeed (2011) }\end{array}$ \\
\hline & $\begin{array}{l}\text { Subglacial Wilkes } \\
\text { land }\end{array}$ & $\begin{array}{l}\text { Detrital zircon } \\
\text { in offshore } \\
\text { Pleistocene } \\
\text { turbidite }\end{array}$ & $\begin{array}{l}\text { 1) } \\
\text { 2) } \\
\text { 3) }\end{array}$ & $\begin{array}{l}\text { 1090-1360 (dominant } 1192 \text { peak) } \\
660-690 \text { (very small population) } \\
513-583 \text { (minor } 515 \text { peak) }\end{array}$ & $\begin{array}{l}\text { 1) } \varepsilon_{\mathrm{Hf}}-3 \text { to }+7 \\
\text { 2) } \varepsilon_{\mathrm{Hf}}+1.5 \\
\text { 3) } \varepsilon_{\mathrm{Hf}}-13 \text { to }-9\end{array}$ & $\begin{array}{l}\text { 1) } 1.75 \\
\text { 2) } 1.5 \\
\text { 3) } 2.1-2.7\end{array}$ & $\begin{array}{l}\text { Veevers \& } \\
\text { Saeed (2011) }\end{array}$ \\
\hline & $\begin{array}{l}\text { Gamburtsev } \\
\text { Subglacial }\end{array}$ & $\begin{array}{l}\text { Detrital zircon } \\
\text { in exposed }\end{array}$ & $\begin{array}{l}\text { 1) } \\
\text { 2) }\end{array}$ & $\begin{array}{l}3150-3350 \\
2600-2900\end{array}$ & $\begin{array}{l}\text { 1) } \varepsilon_{\mathrm{Hf}}-20 \text { to } 0 \\
\text { 2) unknown }\end{array}$ & $\begin{array}{l}\text { 1) } 3.5-3.6 \\
\text { 2) unknown }\end{array}$ & $\begin{array}{l}\text { Veevers \& } \\
\text { Saeed (2008) }\end{array}$ \\
\hline
\end{tabular}




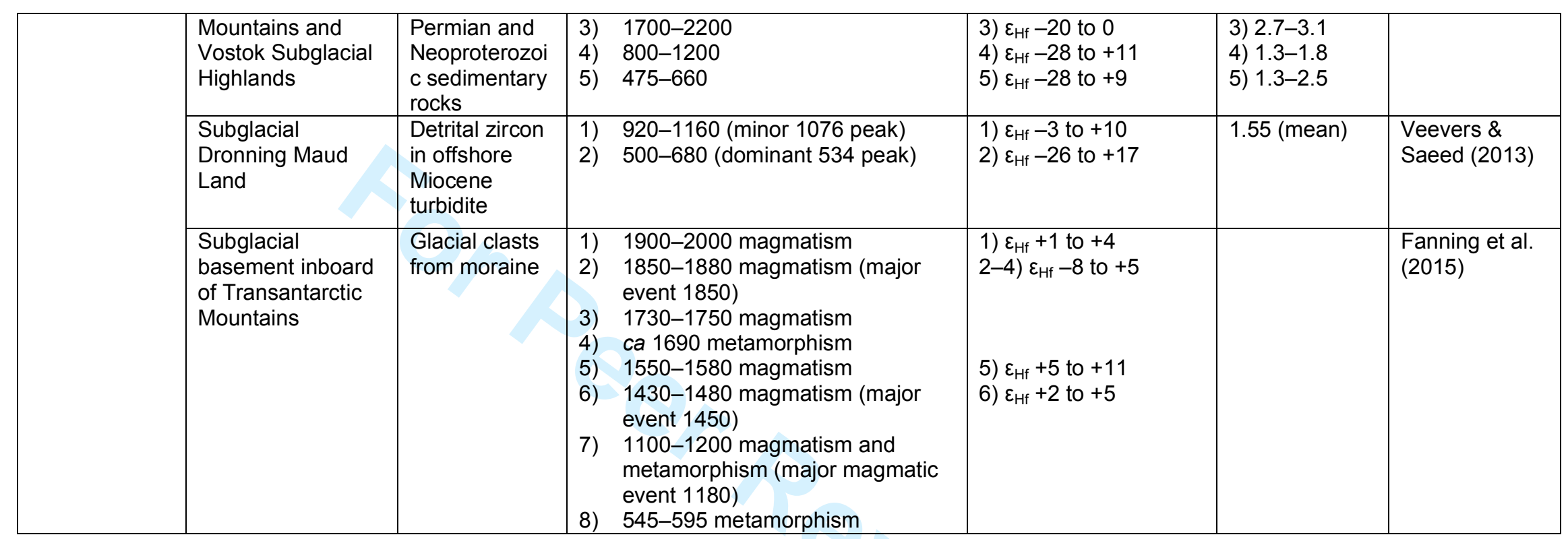


Table 5. Possible Antarctic igneous sources-II Ross Orogen.

\begin{tabular}{|c|c|c|c|c|c|}
\hline $\begin{array}{l}\text { Units/ } \\
\text { lithology }\end{array}$ & & $\begin{array}{l}\text { U-Pb zircon/ whole rock } \\
\text { (Ma) }\end{array}$ & $\begin{array}{l}\varepsilon_{\mathrm{Hf}} \text { and } \varepsilon_{\mathrm{Nd}} \\
\left({ }_{\varepsilon \mathrm{Hf}}=\varepsilon_{\mathrm{Nd}}(\mathrm{i}) \times 1.83+0.60\right)\end{array}$ & Model age (Ga) & References \\
\hline $\begin{array}{l}\text { North Victoria } \\
\text { Land }\end{array}$ & $\begin{array}{l}\text { Calc-alkaline granites } \\
\text { peraluminous granites } \\
\text { high K felsics } \\
\text { high K mafics }\end{array}$ & $\begin{array}{l}481-521 \\
487-494 \\
493-513 \\
487-521 \\
\text { xenocrysts in all } 600,530- \\
540\end{array}$ & & & $\begin{array}{l}\text { Bomparola \& Ghezzo } \\
\text { (1997) }\end{array}$ \\
\hline $\begin{array}{l}\text { North Victoria } \\
\text { Land }\end{array}$ & $\begin{array}{l}\text { diatexite in metamorphic } \\
\text { Wilson Gp intruded by } \\
\text { Granite Harbour } \\
\text { Intrusives }\end{array}$ & $\begin{array}{l}\text { 1) } 544 \pm 4, \text { igneous rim at } \\
469, \text { xenocrysts at } 1130 \\
\text { (dominant), 2800, 2500, } \\
2000 \text { xenocrysts }\end{array}$ & & 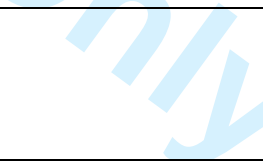 & Black \& Sheraton (1990) \\
\hline $\begin{array}{l}\text { North Victoria } \\
\text { Land }\end{array}$ & $\begin{array}{l}\text { granodiorite-monzonite } \\
\text { suite }\end{array}$ & & $\begin{array}{l}\varepsilon_{\mathrm{Nd}}(\mathrm{T})=-5.6,-4.8 \\
\left(\varepsilon_{\mathrm{Hf}}-9.7,-8.2\right)\end{array}$ & & Ghezzo et al. (1987) \\
\hline $\begin{array}{l}\text { South Victoria } \\
\text { Land }\end{array}$ & $\begin{array}{l}\text { 1) Granite Harbour } \\
\text { Intrusives - Dry Valley } \\
\text { granites } \\
\text { 2) calc-alkaline suite } \\
\text { DV1A (main phase) }\end{array}$ & $\begin{array}{ll}\text { 1) } & 499-531 \text {, mainly } 499- \\
& 505 \\
\text { 2) } & \text { ca } 505 \pm 2 ; 500 \pm 7 \text { to } \\
& 515 \pm 7 \\
\text { 3) } & 516-531 \text { and ca } 488 \pm\end{array}$ & $\begin{array}{l}\text { 2) } \varepsilon_{\mathrm{Nd}}(\mathrm{T})=-4.2 \text { to }-6.1\left(\varepsilon_{\mathrm{Hf}}-7.1\right. \\
\text { to }-10.6) \\
\text { 3) } \varepsilon_{\mathrm{Nd}}(\mathrm{T})=-7.2 \text { to }-1.9\left(\varepsilon_{\mathrm{Hf}}-\right. \\
12.6 \text { to }-2.9) \\
\text { 4) } \varepsilon_{\mathrm{Nd}}(\mathrm{T})=-5.3 \text { to }-4.8\left(\varepsilon_{\mathrm{Hf}}-\right.\end{array}$ & $\begin{array}{l}\text { 2) } 1.1-1.9 \\
\text { 3) } 1.2-1.4\end{array}$ & $\begin{array}{l}\text { Cox et al. (2000), also } \\
\text { Allibone \& Wysoczanski } \\
\text { (2002); Wysoczanski } \\
\text { (Allibone \& 2004) }\end{array}$ \\
\hline
\end{tabular}




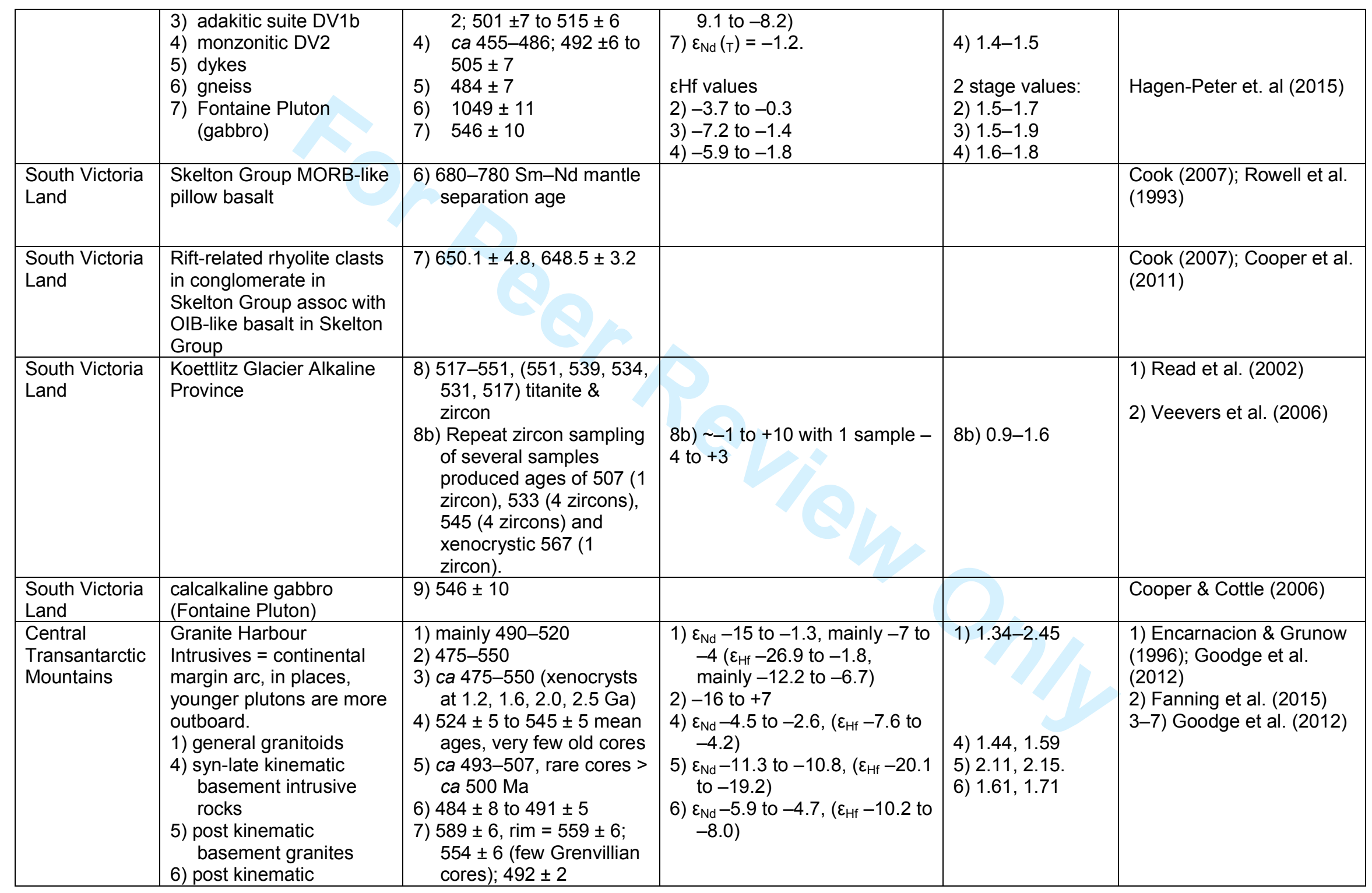




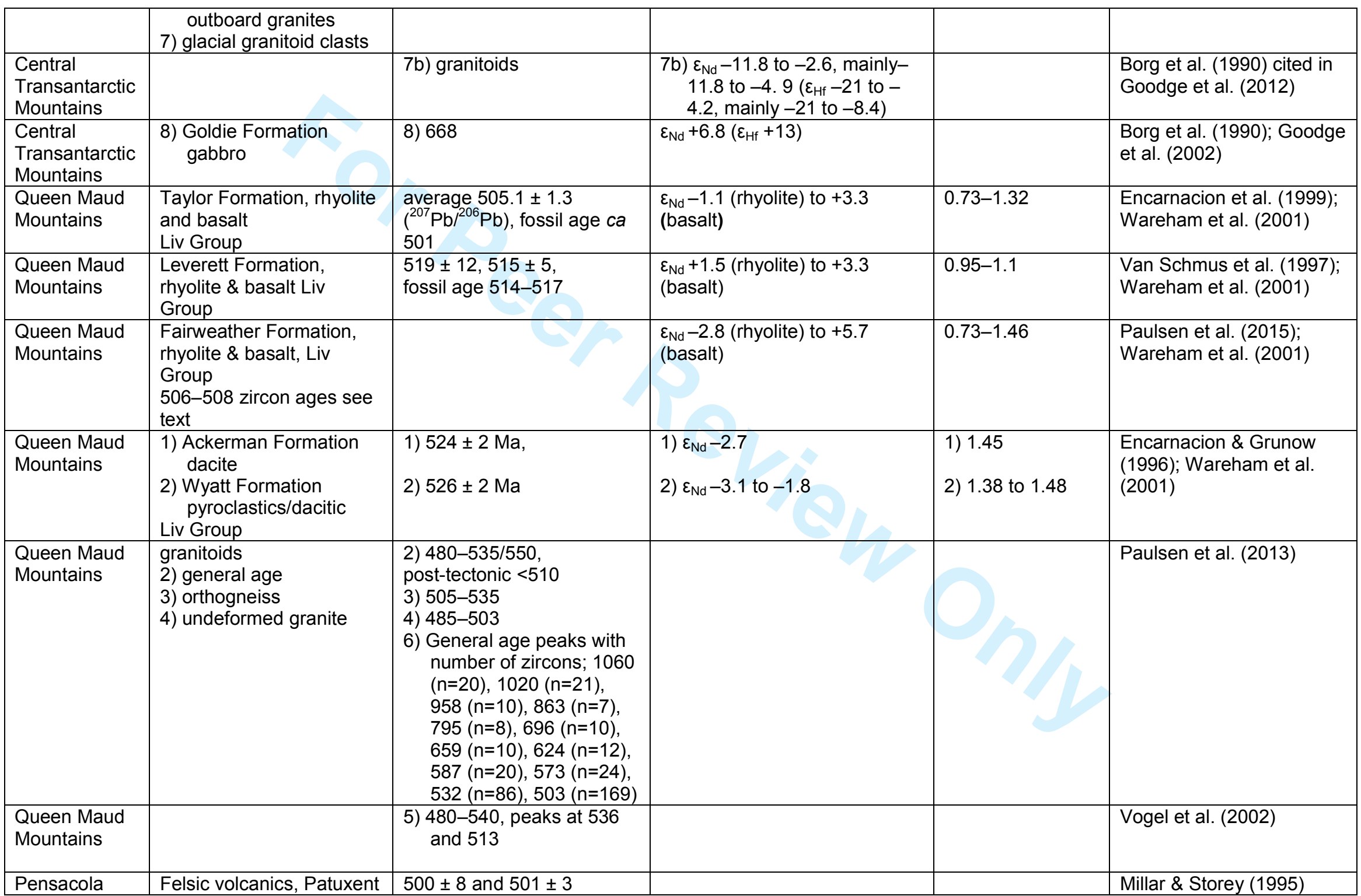


Table 6. Possible Antarctic sedimentary sources - II Ross Orogen

\begin{tabular}{|c|c|c|c|c|c|c|}
\hline Location & Units/lithology & $\mathrm{U}-\mathrm{Pb}$ zircon/whole rock (Ma) & Ar-Ar mica & $\varepsilon_{\mathrm{Hf}}$ & $\begin{array}{l}\text { Model age } \\
\text { (Ga) }\end{array}$ & References \\
\hline $\begin{array}{l}\text { North Victoria } \\
\text { Land }\end{array}$ & $\begin{array}{l}\text { Metasedimentary rocks } \\
\text { in Wilson Terrane, } \\
\text { Berg Group }\end{array}$ & $\begin{array}{l}\text { Main population ca } 500-700 \text { (peaks at } \\
559>545>600>490-\text { ?reset; youngest } \\
\text { 'mean' } 545 \pm 11 \text {, youngest grain } 490 \text { ); } \\
\text { secondary population } 1000-1200 \\
\text { (peaks at } 1071,1036 \text { ). Plus ages } \\
>2000 \text {. Maximum depositional age }= \\
545 \text {. Metamorphic age }=\mathrm{Rb} / \mathrm{Sr}=515 \pm \\
6\end{array}$ & & & & $\begin{array}{l}\text { Adams et al. } \\
(2014)\end{array}$ \\
\hline $\begin{array}{l}\text { North Victoria } \\
\text { Land }\end{array}$ & $\begin{array}{l}\text { Metasedimentary rocks } \\
\text { in Wilson Terrane, } \\
\text { (upper) Priestley } \\
\text { Formation }\end{array}$ & $\begin{array}{l}\text { Main population ca } 800-1200 \text { (peaks at } \\
1064,1028 \text { ); secondary population ca } \\
450-700 \text { (peaks at } 546>477 \text { ). Plus ages } \\
>2000 \text {. Young part maximum } \\
\text { depositional age }=546 \text {. Metamorphic } \\
\text { age }=\mathrm{Rb} / \mathrm{Sr}=512 \pm 19\end{array}$ & & & & $\begin{array}{l}\text { Adams et al. } \\
(2014)\end{array}$ \\
\hline $\begin{array}{l}\text { North Victoria } \\
\text { Land }\end{array}$ & $\begin{array}{l}\text { Wilson Terrane. } \\
\text { metasedimentary rocks } \\
\text { of the lower Priestley } \\
\text { Formation }\end{array}$ & $\begin{array}{l}\text { Main population } 900-1300 \text {; secondary } \\
\text { population } 550-700 \text {, also } 1600-2500 \text {, } \\
700-900\end{array}$ & & & & $\begin{array}{l}\text { Estrada et al. } \\
(2016)\end{array}$ \\
\hline $\begin{array}{l}\text { North Victoria } \\
\text { Land }\end{array}$ & $\begin{array}{l}\text { Bowers Terrane, Molar } \\
\text { Group, (younger part) }\end{array}$ & $\begin{array}{l}\text { Main population } 450-700 \text { (peaks at } \\
597>666>545>498) ; \text { secondary } \\
\text { population } 1000-1250 \text { (peaks at } \\
965>1068,1098,1210 \text { ). Youngest } \\
\text { component } 545 \pm 16\end{array}$ & & & & $\begin{array}{l}\text { Adams et al. } \\
(2014)\end{array}$ \\
\hline $\begin{array}{l}\text { North Victoria } \\
\text { Land }\end{array}$ & $\begin{array}{l}\text { Bowers Terrane, Molar } \\
\text { Group, }\end{array}$ & $\begin{array}{l}\text { Main population } 550-700 \text {; secondary } \\
\text { population } 900-1300 \text {, also } 1600-2500 \text {, } \\
700-900,450-550\end{array}$ & & & & $\begin{array}{l}\text { Estrada et al. } \\
\text { (2016) }\end{array}$ \\
\hline $\begin{array}{l}\text { North Victoria } \\
\text { Land }\end{array}$ & $\begin{array}{l}\text { Robertson Bay } \\
\text { Terrane, Robertson } \\
\text { Bay Group }\end{array}$ & $\begin{array}{l}\text { Main population } 450-650 \text { (peaks at } \\
580>554>512>453 \text {, youngest age } \\
\text { component } 512 \pm 12 \text { ); secondary } \\
\text { population ca } 900-1200 \text { (peak at } 994 \text { ). } \\
\text { Plus ages }>2000 \text {. }\end{array}$ & & & & $\begin{array}{l}\text { Adams et al. } \\
(2014)\end{array}$ \\
\hline $\begin{array}{l}\text { North Victoria } \\
\text { Land }\end{array}$ & $\begin{array}{l}\text { Robertson Bay } \\
\text { Terrane, Robertson } \\
\text { Bay Group }\end{array}$ & $\begin{array}{l}\text { Main population } 550-700 \text {, also } 450- \\
550 \text {; secondary population } 900-1300 \text {, } \\
\text { also } 1600-2500\end{array}$ & & & & $\begin{array}{l}\text { Estrada et al. } \\
(2016)\end{array}$ \\
\hline $\begin{array}{l}\text { North Victoria } \\
\text { Land }\end{array}$ & $\begin{array}{l}\text { 1) Wilson Terrane } \\
\text { a) Berg Group, }\end{array}$ & & $\begin{array}{l}\text { 1a) } 530-600 \\
\text { (youngest } 511,3 \text { at }\end{array}$ & 1) $\begin{aligned} & \varepsilon_{\mathrm{Nd}}-5.4 \text { to }- \\
& 14.5\left(\varepsilon_{\mathrm{Hf}}-9.3\right. \\
&\end{aligned}$ & 1) $1.64-2.22$ & $\begin{array}{l}\text { Henjes-Kunst } \\
(2003) \text {; Henjes- }\end{array}$ \\
\hline
\end{tabular}




\begin{tabular}{|c|c|c|c|c|c|c|}
\hline & 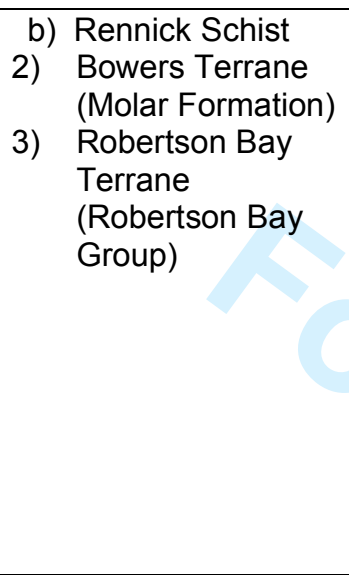 & & \begin{tabular}{|l}
519 ). also $750-$ \\
1170 \\
1b) Renick Schist: $53-$ \\
600 (youngest 505, \\
also 513) also $750-$ \\
1170 \\
2) $500-700$ (youngest \\
500) also 2247, \\
$1480,1390,1130$, \\
830 \\
3) mainly 490-650 \\
(youngest 489- \\
493), 5 grains 830- \\
1125. 1 sample \\
486-524
\end{tabular} & $\begin{array}{l}\text { to }-26.0) \\
\\
\text { 2) } \varepsilon_{\mathrm{Nd}}-1.2 \text { to- } \\
14.3\left(\varepsilon_{\mathrm{Hf}}-1.6\right. \\
\text { to }-25.6) \\
\text { 3) } \varepsilon_{\mathrm{Nd}}-7.6 \text { to }- \\
10.3\left(\varepsilon_{\mathrm{Hf}}-13.3\right. \\
\text { to }-18.3)\end{array}$ & $\begin{array}{l}\text { 2) } 1.71-2.08 \\
\text { 3) } 1.66-1.91\end{array}$ & $\begin{array}{l}\text { Kunst \& } \\
\text { Schüssler } \\
\text { (2003) }\end{array}$ \\
\hline $\begin{array}{l}\text { North Victoria } \\
\text { Land }\end{array}$ & $\begin{array}{l}\text { 1) Meta-sedimentary } \\
\text { rocks in Wilson } \\
\text { Terrane, Priestley } \\
\text { Formation } \\
\text { 2) Molar Group, } \\
\text { Bowers Terrane } \\
\text { 3) Robertson Bay } \\
\text { Group in Robertson } \\
\text { Bay Terrane }\end{array}$ & 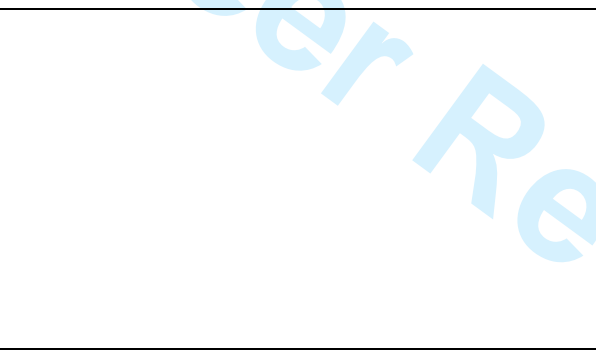 & $\begin{array}{l}\text { 1) } 550-650(55 \%) \\
\text { 2) } 505-560 \text { (youngest } \\
\text { means } 506,516 \text {, } \\
\text { ca } 510) \text {. secondary } \\
650-600 \\
\text { 3) } 480-560 \text { (youngest } \\
\text { mean } 512 \pm 3 \text {; } \\
\text { youngest grains } \\
485,480 \text { ) }\end{array}$ & & $\begin{array}{l}\text { 2) } 1.81,1.94 \\
\text { 3) } 1.66-1.96\end{array}$ & $\begin{array}{l}\text { Di Vincenzo et } \\
\text { al. (2014) }\end{array}$ \\
\hline $\begin{array}{l}\text { South Victoria } \\
\text { Land }\end{array}$ & $\begin{array}{l}\text { Dry Valleys area, } \\
\text { Skelton Group, } \\
\text { YC130/95 }\end{array}$ & $\begin{array}{l}\text { Main population } 900-1500 \text { (peaks at } \\
1315,1063,942) \text {. Also ca } 1515, \text { ca } \\
1500, \text { ca } 1420\end{array}$ & $x_{1}$ & & & $\begin{array}{l}\text { Wysoczanski \& } \\
\text { Allibone (2004) }\end{array}$ \\
\hline $\begin{array}{l}\text { South Victoria } \\
\text { Land }\end{array}$ & $\begin{array}{l}\text { Dry Valleys area, } \\
\text { Skelton Group, } \\
\text { AA195/86 }\end{array}$ & Mean age 1049. Rims ca 553, 532 & & & & $\begin{array}{l}\text { Wysoczanski \& } \\
\text { Allibone (2004) }\end{array}$ \\
\hline $\begin{array}{l}\text { South Victoria } \\
\text { Land }\end{array}$ & $\begin{array}{l}\text { Dry Valleys area, } \\
\text { Skelton Group, } \\
\text { AA21/86 }\end{array}$ & Mean age 1056. Rims 495 & & & & $\begin{array}{l}\text { Wysoczanski \& } \\
\text { Allibone (2004) }\end{array}$ \\
\hline $\begin{array}{l}\text { South Victoria } \\
\text { Land }\end{array}$ & $\begin{array}{l}\text { Dry Valleys area, } \\
\text { Skelton Group, } \\
\text { AA86/86 }\end{array}$ & $\begin{array}{l}\text { Euhedral and thick rims 502. Cores } c a \\
1230,1050\end{array}$ & & & & $\begin{array}{l}\text { Wysoczanski \& } \\
\text { Allibone (2004) }\end{array}$ \\
\hline $\begin{array}{l}\text { South Victoria } \\
\text { Land }\end{array}$ & $\begin{array}{l}\text { Dry Valleys area, } \\
\text { Skelton Group, } \\
\text { AA191M2/86 }\end{array}$ & $\begin{array}{l}\text { ca } 1000-1100 \text { (mean 1055), } 13 \text { grains } \\
\text { with mean of } 494=\mathrm{Pb} \text { loss during } \\
\text { metamorphism }\end{array}$ & & & & $\begin{array}{l}\text { Wysoczanski \& } \\
\text { Allibone (2004) }\end{array}$ \\
\hline South Victoria & Skelton Group, Radian, & Main population ca $875-1250$ (peaks at & & & & Cooper et al. \\
\hline
\end{tabular}




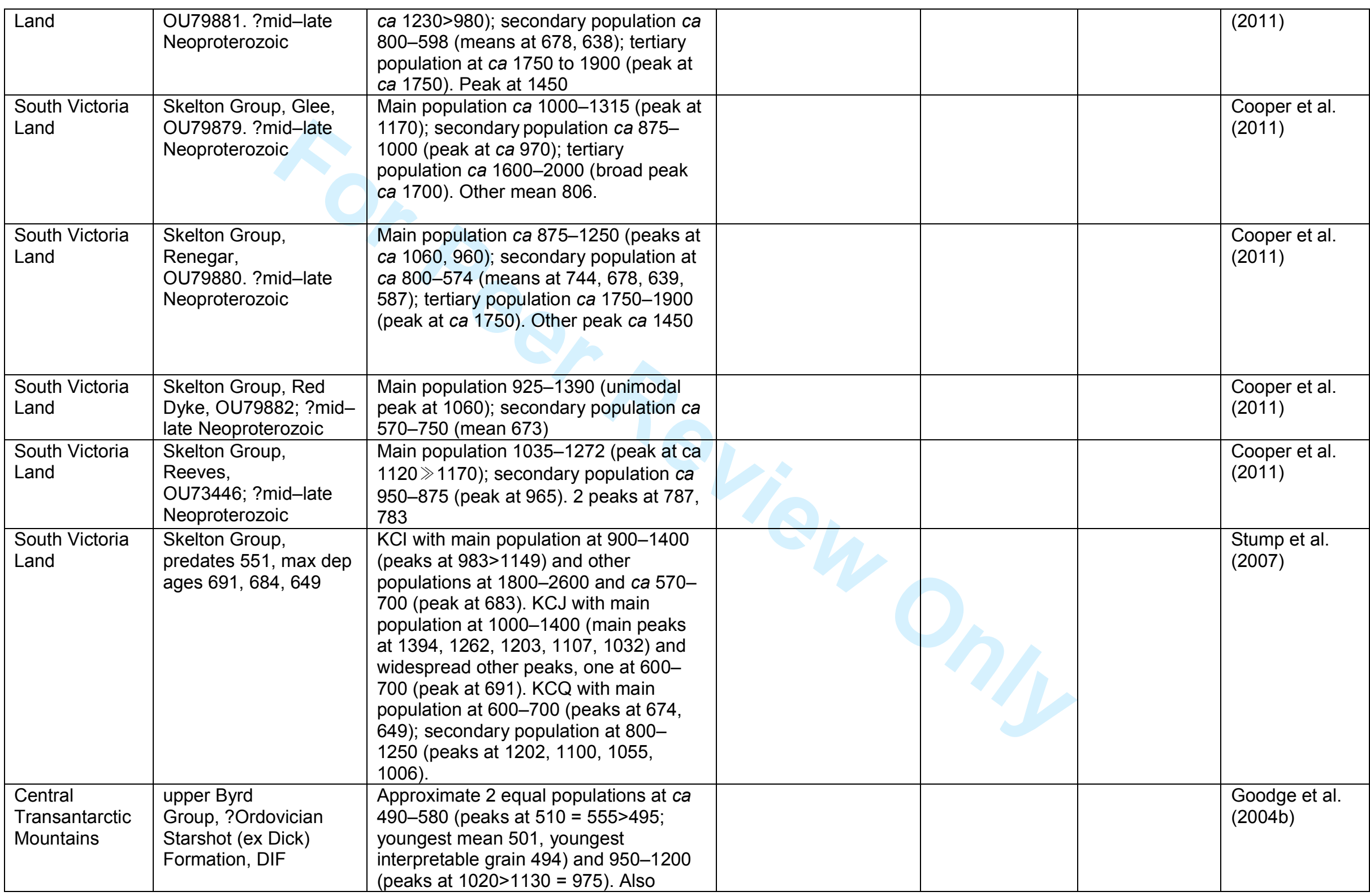




\begin{tabular}{|c|c|c|c|c|c|c|}
\hline & & $\begin{array}{l}\text { population at } 650-900 \text { (peaks at } \\
695>850) \text {. Other population } 1200-1300 \\
\text { (peak at 1250). Also older peaks ( } 1485 \\
\text { and above) }\end{array}$ & & & & \\
\hline $\begin{array}{l}\text { Central } \\
\text { Transantarctic } \\
\text { Mountains }\end{array}$ & $\begin{array}{l}\text { upper Byrd } \\
\text { Group, ?Ordovician } \\
\text { Starshot Formation, } \\
\text { USF }\end{array}$ & $\begin{array}{l}\text { Main population ca } 480-650 \text { (peaks at } \\
520>>545>580 ; \text { youngest mean } 501, \\
\text { youngest grains } 473,488,489 \text { ); } \\
\text { secondary population at } 900-1250 \\
\text { (peaks at } 995= \\
1035>1080>1130>1225) \text {. Small peaks } \\
\text { at } 2850,2290,1840,875\end{array}$ & $\begin{array}{l}\text { Detrital muscovite } \\
\text { population } 485^{*}-524 \\
\text { (est 502-524) (peaks } \\
\text { at 506; 503). } \\
\text { Youngest mean } 504 \pm \\
\text { 3. ( }{ }^{*}=\text { Ar loss) }\end{array}$ & & & $\begin{array}{l}\text { Goodge et al. } \\
\text { (2004a.b) }\end{array}$ \\
\hline $\begin{array}{l}\text { Central } \\
\text { Transantarctic } \\
\text { Mountains }\end{array}$ & $\begin{array}{l}\text { upper Byrd Group, } \\
\text { middle Cambrian (?506 } \\
\text { Ma) Douglas } \\
\text { Conglomerate, DCS }\end{array}$ & $\begin{array}{l}\text { Main population ca } 490-600, \text { (almost } \\
\text { unimodal peak at } 520 ; \text { youngest mean } \\
506, \text { youngest grains } 491,504 \text { ). Very } \\
\text { low populations at } 950-1200 \text { (peak at } \\
1050), 1500-1700 \text { (peak at } 1600 \text { ) and } \\
\text { peak also at } 2320 \text {. }\end{array}$ & & & & $\begin{array}{l}\text { Goodge et al. } \\
(2004 b)\end{array}$ \\
\hline $\begin{array}{l}\text { Central } \\
\text { Transantarctic } \\
\text { Mountains }\end{array}$ & $\begin{array}{l}\text { upper Byrd Group, late } \\
\text { early Cambrian (ca } \\
512-513 \mathrm{Ma} \text { ) } \\
\text { Douglas/Starshot } \\
\text { Formation, HRS }\end{array}$ & $\begin{array}{l}\text { Main population ca } 490-700 \text { (peaks at } \\
545 \gg 495=650 \text {; youngest mean } 510, \\
\text { youngest grain } 491 \text { ). Also very small } \\
\text { peaks at } 2510,2440,1490,1240,1040 \text {, } \\
780\end{array}$ & 10 & $\begin{array}{l}\varepsilon_{\mathrm{Nd}}-6.9\left(\varepsilon_{\mathrm{Hf}}-\right. \\
12.0)\end{array}$ & & $\begin{array}{l}\text { Goodge et al. } \\
(2004 b, 2012)\end{array}$ \\
\hline $\begin{array}{l}\text { Central } \\
\text { Transantarctic } \\
\text { Mountains }\end{array}$ & $\begin{array}{l}\text { upper Byrd Group, } \\
\text { early Cambrian } \\
\text { Starshot Formation, } \\
\text { SRG, ex } 98206 \mathrm{~A}\end{array}$ & $\begin{array}{l}\text { Main population ca } 500-650 \text { (peaks at } \\
560 \gg 530 \text {; youngest mean } 531 \text {, } \\
\text { youngest grain } 527 \text { ); secondary } \\
\text { population ca } 1000-1150 \text { (peak at } \\
1100 \text { ). Peaks also at } 940>810>720 \text {. }\end{array}$ & $\begin{array}{l}\text { Detrital muscovite } \\
\text { population } 491^{*}-584 \\
\text { (est } 501-584) \text { (peaks } \\
\left.\text { at } 497^{*}, 518\right) \text {. } \\
\text { Youngest mean } 518 \pm \\
4 .\end{array}$ & & 1.79 & $\begin{array}{l}\text { Goodge et al. } \\
(2002,2004 a \text {, } \\
\text { b, 2012) }\end{array}$ \\
\hline $\begin{array}{l}\text { Central } \\
\text { Transantarctic } \\
\text { Mountains }\end{array}$ & $\begin{array}{l}\text { upper Byrd Group, } \\
\text { early Cambrian } \\
\text { Starshot Formation, } \\
\text { DSG, ex } 98268 G\end{array}$ & $\begin{array}{l}\text { Main population } 500-700 \text { (peaks at } \\
565 \gg 585 \text {; youngest mean } 547, \\
\text { youngest grain } 526 \text { ); secondary } \\
\text { population ca } 1000-1250 \text { (peaks at } \\
1085>>1200 \text { ); tertiary population at } \\
1400-1900 \text { (peaks at } 1670= \\
1835>1410 \text { ). Population at } 810-830 \\
\text { (peak at } 825 \text { ). Other peak } 2100 .\end{array}$ & $\begin{array}{l}\text { Detrital muscovite } \\
\text { population } 545-501^{*} \\
\text { (est } 516-545) \text { (peaks } \\
\text { at } 530,517) . \\
\text { Youngest mean } 516 \pm \\
5\end{array}$ & $\begin{array}{l}\varepsilon_{\mathrm{Nd}} 5.9\left(\varepsilon_{\mathrm{Hf}}-\right. \\
10.2)\end{array}$ & 1.71 & $\begin{array}{l}\text { Goodge et al. } \\
(2002,2004 a \text {, } \\
\text { b, 2012) }\end{array}$ \\
\hline
\end{tabular}




\begin{tabular}{|c|c|c|c|c|c|c|}
\hline $\begin{array}{l}\text { Central } \\
\text { Transantarctic } \\
\text { Mountains }\end{array}$ & $\begin{array}{l}\text { upper Byrd Group, } \\
\text { early Cambrian } \\
\text { Starshot Formation } \\
\text { CBG }\end{array}$ & & $\begin{array}{l}\text { Detrital muscovite } \\
\text { population } 481^{*}-515 \\
\text { (est } 495-516),(\text { peaks } \\
\left.\text { at } 486^{*}, 510\right) . \\
\text { Youngest mean } 510 \pm \\
3\end{array}$ & & & $\begin{array}{l}\text { Goodge et al } \\
(2004 a)\end{array}$ \\
\hline $\begin{array}{l}\text { southern part } \\
\text { Central } \\
\text { Transantarctic } \\
\text { Mountains }\end{array}$ & $\begin{array}{l}\text { Byrd Group, Cambrian, } \\
\text { Starshot Formation, } \\
\text { RAM1 maximum } \\
\text { deposition age }=558\end{array}$ & $\begin{array}{l}\text { Main population } 539-630 \text { (peaks at } \\
570>657>556=607 \text { ); secondary } \\
\text { population } 632-723 \text { (peaks at } 695,657, \\
715 \text { ). Other populations at } 983-1215 \\
\text { (peak at } 1085 \text { ) and } 736-796 \text { (peak at } \\
770 \text { ) }\end{array}$ & & & & $\begin{array}{l}\text { Paulsen et al. } \\
\text { (2015) }\end{array}$ \\
\hline $\begin{array}{l}\text { southern part } \\
\text { Central } \\
\text { Transantarctic } \\
\text { Mountains }\end{array}$ & $\begin{array}{l}\text { Byrd Group, Cambrian, } \\
\text { Starshot Formation, } \\
\text { RAM2. mda }=550 \\
\text { mean }\end{array}$ & $\begin{array}{l}\text { Main population } 517-696 \text { (peaks at } \\
549>563 \gg 584>602>636>662>682 \text { ); } \\
\text { secondary population at } 939-1297 \\
\text { (peaks at } 1028=1088 \text { ); tertiary } \\
\text { population } 859-891 \text { (peak at } 874 \text { ) }\end{array}$ & $\begin{array}{l}\text { Main detrital } \\
\text { muscovite population } \\
527-579 \text { (peaks at } \\
546>553>529=572), \\
\text { mainly ca } 540-570 \text {. } \\
\text { Secondary population } \\
627-647 \text { (peaks at } \\
632=643 \text { ). Tertiary } \\
\text { population at } 580-610\end{array}$ & & & $\begin{array}{l}\text { Paulsen et al. } \\
\text { (2015) }\end{array}$ \\
\hline $\begin{array}{l}\text { Central } \\
\text { Transantarctic } \\
\text { Mountains }\end{array}$ & $\begin{array}{l}\text { lower Byrd Group, } \\
\text { early Cambrian } \\
\text { Shackleton Limestone } \\
\text { SLB }\end{array}$ & $\begin{array}{l}\text { Main population } 1300-1700 \text { (peaks at } \\
1515>1610>1420 \text { ); secondary } \\
\text { population } 1050-1250 \text { (peak at } \\
1135>1195 \text { ). Youngest mean } 959, \\
\text { youngest grain } 956, \text { youngest peak } 970\end{array}$ & & & & $\begin{array}{l}\text { Goodge et al. } \\
(2004 b)\end{array}$ \\
\hline $\begin{array}{l}\text { South Victoria } \\
\text { Land }\end{array}$ & $\begin{array}{l}\text { Hobbs Formation, } \\
\text { Skelton Group KHF }\end{array}$ & $\begin{array}{l}\text { Main population } 900-1400 \text { (peaks at } \\
1072>1163>1000=1320) \text {; secondary } \\
\text { population } 1900-1650 \text { (peak at } 1842 \\
\text { and } 1 \text { grain at } 663 \text { and } 1 \text { at } 690) \text {. Other } \\
\text { peaks } 2315,1842\end{array}$ & & & & $\begin{array}{l}\text { Goodge et al. } \\
(2004 b)\end{array}$ \\
\hline $\begin{array}{l}\text { Central } \\
\text { Transantarctic } \\
\text { Mountains }\end{array}$ & $\begin{array}{l}\text { Beardmore Group, } \\
\text { Neoproterozoic Goldie } \\
\text { Formation CPG1, ex } \\
98260\end{array}$ & $\begin{array}{l}2 \text { populations. Main at ca } 1400-1900 \\
\text { (age peaks at } \\
1490>1795>1550>1435>>1690= \\
1840) \text {; secondary small population at } \\
1050-1250 \text { (peaks at } 1095>1220) \text {. } \\
\text { Youngest grain 1065. Extra peaks at } \\
2600,2031\end{array}$ & & $\begin{array}{l}\varepsilon_{\mathrm{Nd}}-11.9\left(\varepsilon_{\mathrm{Hf}}-\right. \\
21.2)\end{array}$ & 2.19 & $\begin{array}{l}\text { Goodge et al. } \\
(2002,2004 b \text {, } \\
2012)\end{array}$ \\
\hline Central & Beardmore Group, & Main population $=1400-1900$ (peaks at & $1174 \pm 15$ & & & Goodge et al. \\
\hline
\end{tabular}

URL: http://mc.manuscriptcentral.com/taje 


\begin{tabular}{|c|c|c|c|c|c|c|}
\hline $\begin{array}{l}\text { Transantarctic } \\
\text { Mountains }\end{array}$ & $\begin{array}{l}\text { Neoproterozoic } \\
\text { Goldie Formation } \\
\text { CPG2 }\end{array}$ & $\begin{array}{l}1560>1765>1445) \text {; secondary } \\
\text { population at } 900-1200 \text { (peak at } 1175) \text {. } \\
\text { Other peak at } 2500 .\end{array}$ & & & & (2004b) \\
\hline $\begin{array}{l}\text { Central } \\
\text { Transantarctic } \\
\text { Mountains }\end{array}$ & $\begin{array}{l}\text { Beardmore Group, } \\
\text { Neoproterozoic } \\
\text { Cobham Formation } \\
\text { CBF, ex } 98229\end{array}$ & $\begin{array}{l}3 \text { populations: } 1 \text { at ca } 2500-3000 \\
\text { (peaks at } 2810 \gg 2965 \text { ). Population } 2 \text { at } \\
\text { ca } 1600-1900 \text { (peaks at } \\
1825>1735>1615 \text { ). Small peak at } 1145\end{array}$ & $1461 \pm 16$ & $\begin{array}{l}\varepsilon_{\mathrm{Nd}}-14.4\left(\varepsilon_{\mathrm{Hf}}-\right. \\
25.8)\end{array}$ & 2.39 & $\begin{array}{l}\text { Goodge et al. } \\
\text { (2002, 2004b, } \\
2012)\end{array}$ \\
\hline $\begin{array}{l}\text { Central } \\
\text { Transantarctic } \\
\text { Mountains }\end{array}$ & $\begin{array}{l}\text { Beardmore Group, } \\
\text { Neoproterozoic } \\
\text { sandstone, PAS, } \\
\text { placed in Cobham } \\
\text { Formation. }\end{array}$ & $\begin{array}{l}2 \text { populations. Main one at } 1650-1900 \\
\text { (peaks at } 1805=1770=1850>1725 \text { ); } \\
\text { secondary population at } 1400-1600 \\
\text { (peaks at } 1580>1475 \text { ). Small peaks } \\
\text { also at } 2950,2440 .\end{array}$ & $1461 \pm 30$ & & & $\begin{array}{l}\text { Goodge et al. } \\
\text { (2004b) }\end{array}$ \\
\hline $\begin{array}{l}\text { Central } \\
\text { Transantarctic } \\
\text { Mountains }\end{array}$ & $\begin{array}{l}\text { Beardmore Group, } \\
\text { Neoproterozoic } \\
\text { conglomerate, PAC, } \\
\text { placed in Cobham } \\
\text { Formation. }\end{array}$ & $\begin{array}{l}\text { Main population } 1400-1900 \text { (peaks at } \\
1525>1435>1630>1780 \text { ); secondary } \\
\text { population at } 1100-1300 \text { (peaks at } \\
1125=1235 \text { ). Extra peak at } 2465\end{array}$ & $1125 \pm 30$ & & & $\begin{array}{l}\text { Goodge et al. } \\
\text { (2004b) }\end{array}$ \\
\hline $\begin{array}{l}\text { Central } \\
\text { Transantarctic } \\
\text { Mountains }\end{array}$ & Nimrod Group & Archean-Paleoproterozoic & & $\begin{array}{l}\varepsilon_{\mathrm{Nd}}(\mathrm{T}) \text { values } \\
\text { of-21 to }-24 \\
\left(\varepsilon_{\mathrm{Hf}}-37.9 \text { to }-\right. \\
43.7)\end{array}$ & & $\begin{array}{l}\text { Goodge et al. } \\
\text { (2004b) } \\
\text { (Borg et al. } \\
\text { 1990). }\end{array}$ \\
\hline $\begin{array}{l}\text { Queen Maud } \\
\text { Mountains }\end{array}$ & $\begin{array}{l}\text { Early-middle Cambrian } \\
\text { Liv Group, correlate of } \\
\text { Byrd Group, quartzite } \\
\text { in Fairweather } \\
\text { Formation, ASO }\end{array}$ & $\begin{array}{l}\text { Population } 436-559 \text { (unimodal peak at } \\
506 \text {, very small peak at } 548 \text { ) }\end{array}$ & & & & $\begin{array}{l}\text { Paulsen et al. } \\
\text { (2015) }\end{array}$ \\
\hline $\begin{array}{l}\text { Queen Maud } \\
\text { Mountains }\end{array}$ & $\begin{array}{l}\text { Early-middle Cambrian } \\
\text { Liv Group, correlate of } \\
\text { Byrd Group, quartz- } \\
\text { mica schist form } \\
\text { Henson Marble } \\
\text { Member, Fairweather } \\
\text { Formation ,12-13-95 }\end{array}$ & $\begin{array}{l}\text { Main population } 454-580 \text { (peaks at } 529 \\
=508=520>>488=563=508) \\
\text { secondary population } 627-652 \text { (peak }= \\
640)\end{array}$ & & & & $\begin{array}{l}\text { Paulsen et al. } \\
\text { (2015) }\end{array}$ \\
\hline $\begin{array}{l}\text { Queen Maud } \\
\text { Mountains }\end{array}$ & $\begin{array}{l}\text { Early-middle Cambrian } \\
\text { Liv Group, correlate of } \\
\text { Byrd Group, Taylor } \\
\text { Formation, LUB2B. } \\
\text { Interbeddded rhyolite = } \\
516 \pm 6\end{array}$ & $\begin{array}{l}\text { Main population } 514-658 \text { (peaks at } \\
558 \gg 588>536=608=636 \text { ); secondary } \\
\text { population } 650-800 \text { (peaks at } \\
684>705) \text {; tertiary population } 978-1199 \\
\text { (peaks at } 1121=1058) . \text { Older peaks at } \\
1647,1725\end{array}$ & & & & $\begin{array}{l}\text { Paulsen et al. } \\
\text { (2015); Van } \\
\text { Schmus et al. } \\
\text { (1997) }\end{array}$ \\
\hline Queen Maud & Early-middle Cambrian & Unimodal 445-550 (peak = 504) & & & & Paulsen et al. \\
\hline
\end{tabular}




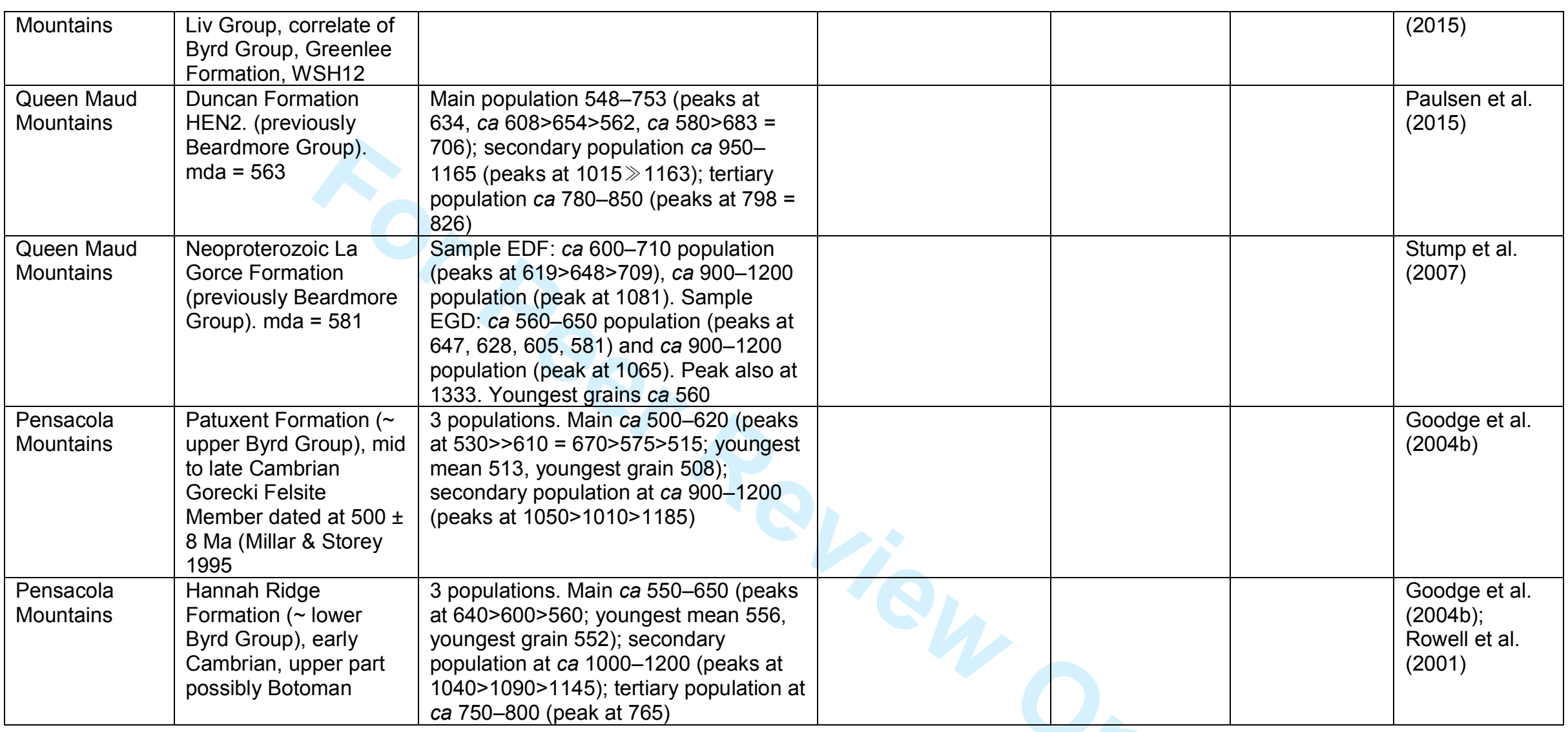

